Historic, Archive Document

Do not assume content reflects current scientific knowledge, policies, or practices. 



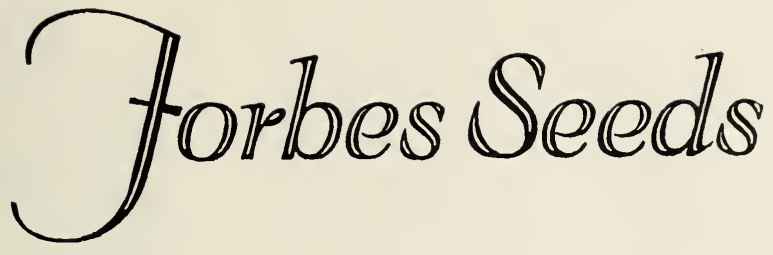

I929

ALEXANDER FORBES \& CO.

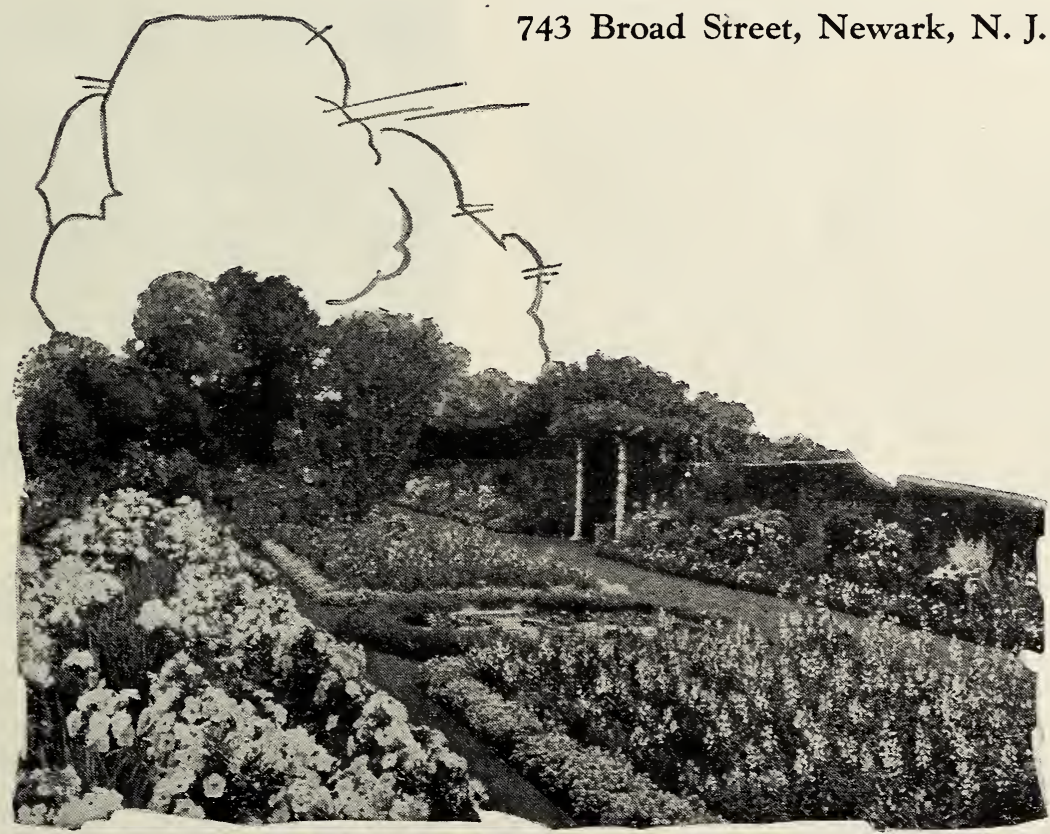

Being the third of a series of booklets devoted to beautiful things. Another will follow next month 
F OR more than 30 years, Alexander 1 Forbes \& Co. have supplied flower and vegetable seeds for the gardens of Newark and northern New Jersey and have done much to make a better community. Forbes Seeds have become an increasingly important factor in the nation's vegetable production for they are now used each year by thousands of commercial truckgrowers around most of the important centers of population.

You may particularly enjoy some celery served in a Salt Lake City hotel, cantaloupe on a Santa Fé diner, peas bought at a roadside stand upstate New York, or California-grown lettuce from your own green grocer. If these were traced back to production, many would be found to originate from Forbes Seeds of Newark, N. J.

\section{Quality and Confidence}

The use of our principal product has steadily increased because of quality. No one can tell the difference by inspection, between good and bad seeds. The planter must have confrdence in his seedsman. Forbes Seeds are held at a very high standard to merit this confrdence. Seeds of the best strains are produced under conditions which suit them best, in this country and in many foreign Iands. These are assembled and cleaned to meet exacting requirements, tested for purity and vitality and carefully packaged. An extensive trial-ground has long been maintained, now at RoseIand, N. J., where all seeds are field-proved under practical conditions.

\section{Former Location}

For many years, this business was conducted at 115 Mulberry Street, Newark, but the inconvenience of that location for shoppers and the increasing demand for Forbes Seeds urged its removal to more accessible quarters. As a result, Forbes Garden Store, on Broad Street was opened in April of last year and the old stand continued for warehouse use.
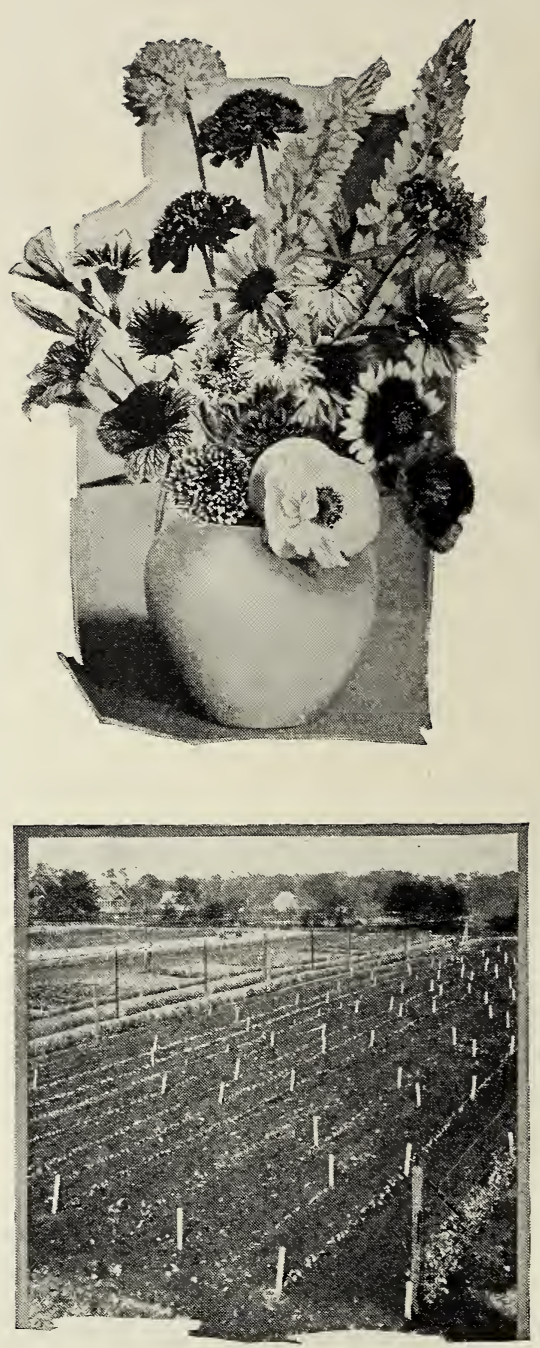

A view of part of our trial ground

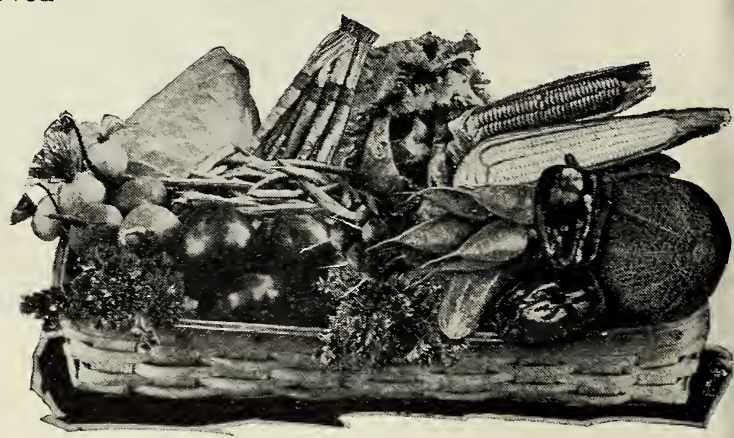




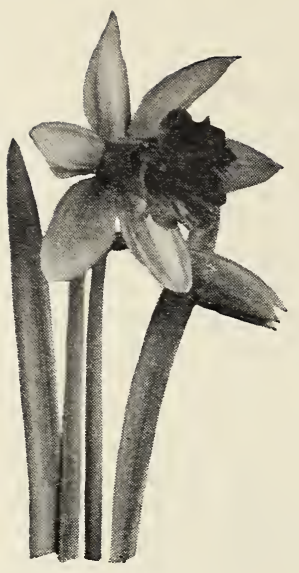

\section{Next Autumn}

In September, we will send you our fall booklet on Tulips, Narcissus, Hyacinths and others, as Peonies, Lilies, and Irises. This includes many unusual house plants for the winter's enjoyment; goldfish and tropical fish, aquaria, songful canary birds and attractive cages.

\section{Before the Holidays}

Our "Gifts for the Holidays" will present colorful Christmas flowering plants and a puzzling choice of beautiful things in glass, metal, marble, and pottery - wares from many lands -all having distinctive charm. At that time a very unusual assortment of greeting cards will be displayed in our store.
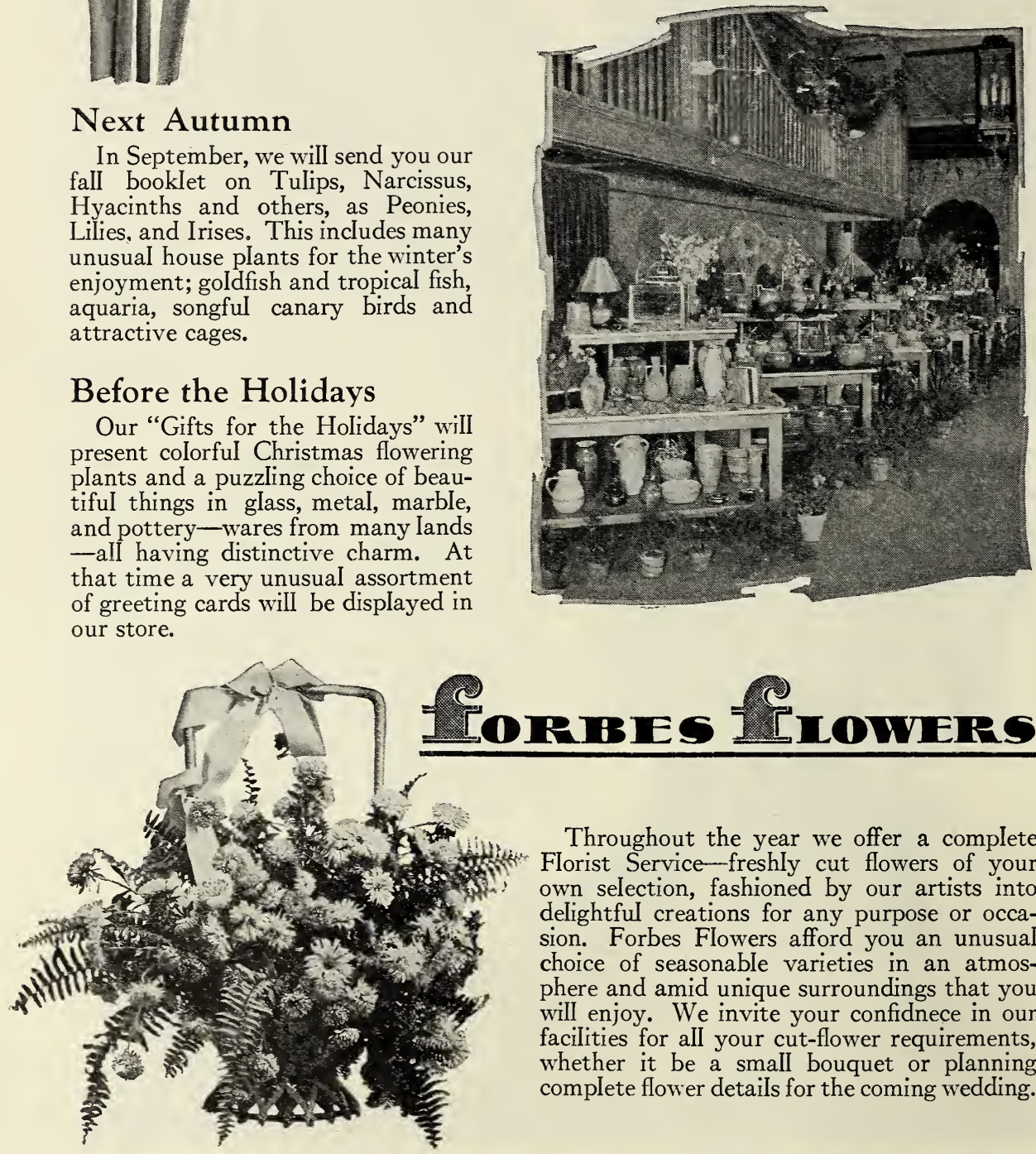

Throughout the year we offer a complete Florist Service-freshly cut flowers of your own selection, fashioned by our artists into delightful creations for any purpose or occasion. Forbes Flowers afford you an unusual choice of seasonable varieties in an atmosphere and amid unique surroundings that you will enjoy. We invite your confidnece in our facilities for aII your cut-flower requirements, whether it be a small bouquet or planning complete flower details for the coming wedding. 


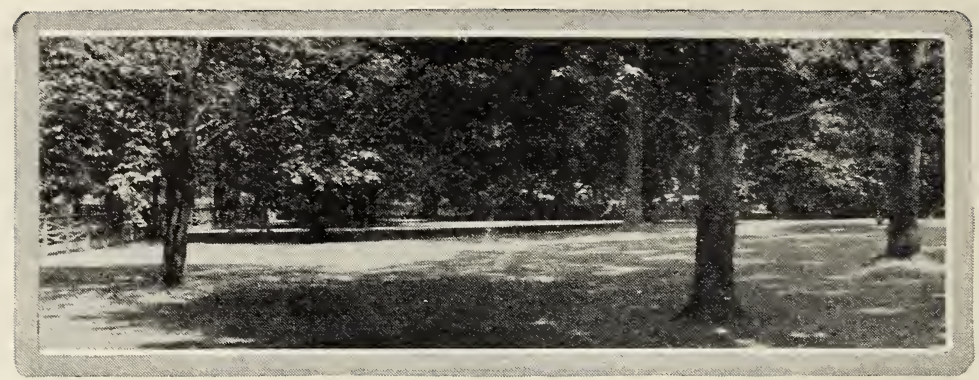

\section{Shady Place Lawn Grass Seed}

It is difficult to grow grass in the shade and under trees because the trees use up nearly all the food and moisture in the soil. This mixture will thrive better than any other and is the best possible for under trees. Water frequently until the grass has made a good start. 1/2Ib. 40 cts.; Ib. 75 cts.; 2 Ibs. \$1.40; 5 Ibs. \$3.25; 10 Ibs. \$6; 25 Ibs. \$14; 100 Ibs. \$55.

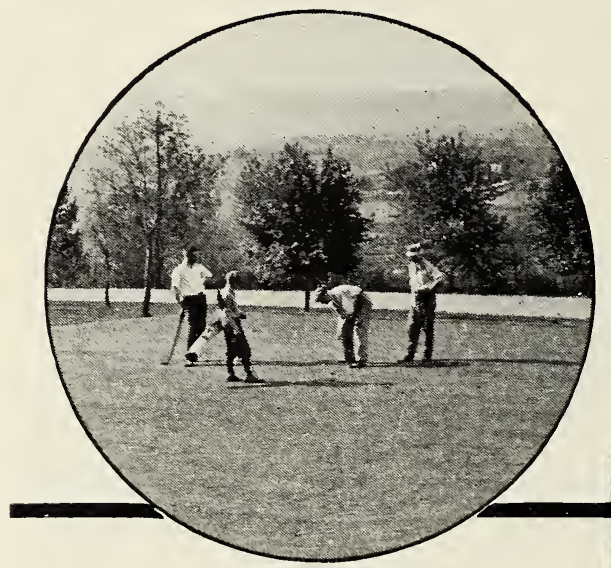

\section{Terrace Lawn Grass Seed}

The grasses used for a sloping bank or terrace must have such roots as will withstand the washing caused by heavy rains. This mixture forms a network of densely matted roots of deep-rooting character. These deep roots will better withstand drought during the summer as they reach down below the surface dryness. After seeding, cover with a little soil and firm down to keep from washing out. $1 / 2 \mathrm{lb}$. 40 cts.; Ib. 75 cts.; 2 lbs. \$1.40; 5 Ibs. \$3.25; 10 Ibs. \$6; 25 Ibs. \$14.

\section{Home Putting-Green Seed}

Many golf enthusiasts have devoted a part of the lawn to a home putting-green and at moderate expense. We have prepared this mixture specially for this purpose. We use the very frnest grasses including genuine German Creeping Bent. A putting-green requires care. 15 lbs. will seed a green $25 \times 25 \mathrm{ft}$. L.b. 95 cts.; 5 lbs. $\$ 4.50 ; 25$ Ibs. $\$ 20 ; 100$ Ibs. $\$ 75$.

\section{White Clover}

Dark green compact foliage. Used where it has been found difficult to produce a lawn with grass seed only. $1 / 4$ Ib. 25 cts.; $1 / 2 \mathrm{lb}$. 40 cts.; lb. 65 cts. Use $1 \mathrm{Ib}$. with $25 \mathrm{Ibs}$. of lawn seed.

We prepay transportation charges on all Lawn Grass Seed Mixtures

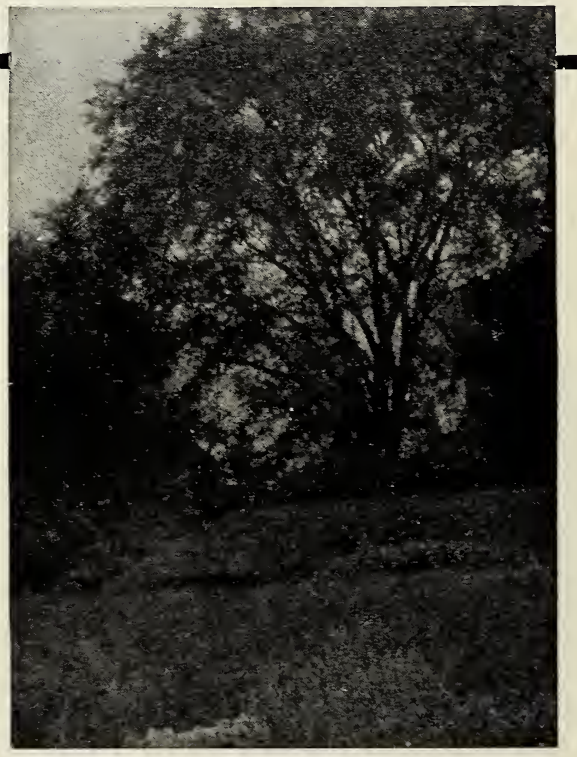




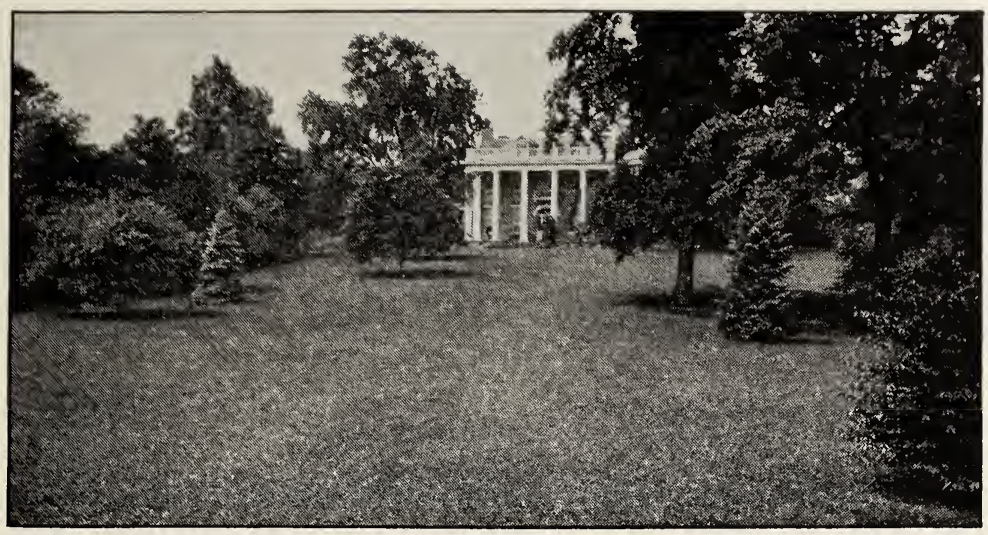

\section{The "Forbes" Lawn Grass Seed}

is a rapid-growing combination of grasses and produces in from four to six weeks, a permanent lawn capable of withstanding heavy wear. It contains seeds of six dwarf evergreen and perennial grasses of fine Iawn texture. Definite proportions of these are mixed very thoroughly. The resultant lawn has a fine, even, rich green appearance and a permanency not usually found. is known the country over for its high quality. It is higher priced than ordinary store mixtures but is cheapest in the long run. It contains only heavy, recleaned, live seeds, free from worthless chaff and weed seeds. It is backed by our national reputation for fair dealing and finest quality. We do not use any White Clover seed in this lawn mixture.

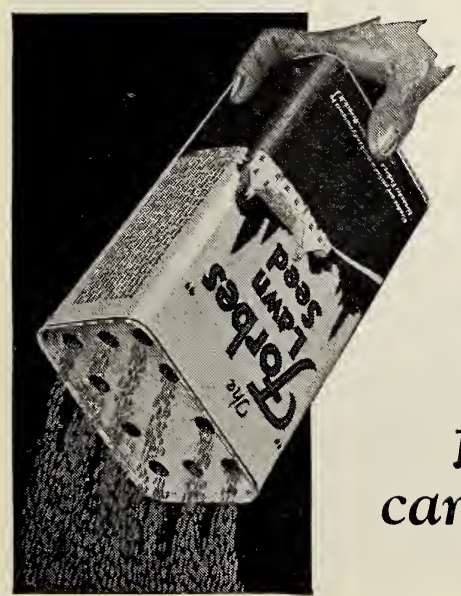

Prices: $1 / 2$ lb. 35 cts.; lb. 60 cts.; 2 lbs. $\$ 1.10$; 5 lbs. $\$ 2.50 ; 10$ lbs. $\$ 4.75 ; 25$ lbs. $\$ 11.50$; 100 lbs. $\$ 45$, all delivered.

FOR your convenience here is The F "Forbes" Lawn Seed in a handy, ready-to-sow container. Just push in the plugs in the top and scatter the seed evenly. Complete directions on label.

\section{Send} for this can today
For quick results, sow $11 / 2$ Ibs. to every 400 sq. $\mathrm{ft}$. ( 20 by $20 \mathrm{ft}$.) of new ground, or 150 lbs. to the acre. One pound to $400 \mathrm{sq}$. $\mathrm{ft}$. or 100 Ibs. per acre will give good results but will take a longer time.

A 3-lb.can of The "Forbes" Lawn Grass Seed postpaid for $\$$ I.7o. Trial can of $I 1 / 2$ lbs. postpaid for $85 \mathrm{cts}$.

We prepay transportation charges on all Lawn Grass Seed Mixtures 


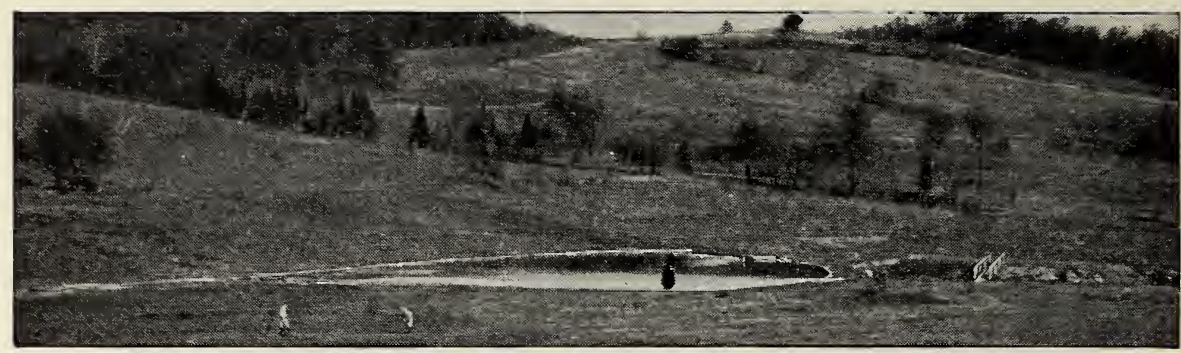

A real invitation to do your best

\section{Grass Seeds for Golf}

Most greenkeepers know that a seed mixture of several grasses gives a quicker, more uniform stand than a seeding of but one variety of grass. Turf from a mixture is far more enduring and is not affected as much by brown patch and other fungous diseases. The feeding roots from mixed grasses are at various depths in the soil, commanding more moisture during dry seasons and having better average drainage in wet seasons. With mixtures all dependence is not placed on one grass, and the turf keeps more uniform.

Much subsequent labor and expense are saved by using the finest quality grass seeds at the outset. The grasses in our mixtures are recleaned to a very high degree of purity and are of high vitality. They cost more than ordinary commercial qualities but in seeding grass it is far more satisfactory and more economical to use only the best quality.

\section{Putting-Green Mixture}

The finest imported and domestic grass seeds of varieties best suited to putting-greens are used in this blend. We include a large proportion of genuine German Creeping Bent (Agrostis vulgaris). The resultant turf is very fine and close, yet durable. Use $1 \mathrm{Ib}$. per 100 sq. ft. for seeding new greens and about half that quantity for renovating old ones. Lb. 90 cts.; 25 Ibs. \$20; 100 Ibs. \$75.

\section{Fair-Green Mixture}

This blend consists of those grasses which will thrive without any particular attention and yet give a fine, springy, close turf of enduring character. Use 200 lbs. to the acre on new fairways and one-half this quantity for renovating established ones. Lb. 60 cts.; 25 Ibs. \$12.50; 100 Ibs. \$45.

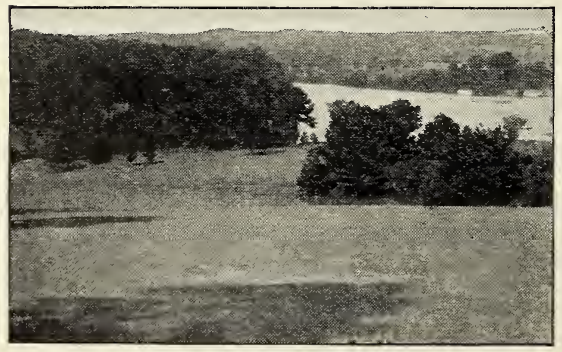

An interesting Fairway

\section{Tee Mixture}

This special mixture is composed of extremely deep-rooting grasses that stand great wear. Sow 10 Ibs. to 1,000 sq. ft. Lb. 65 cts.; 25 Ibs. \$13; 100 Ibs. \$50.

\section{Bunker Mixture}

A mixture of Red, Hard, Dwarf, Fineleaved, Various-leaved, and Tall Fescues. Excellent for mounds, and exposed sandy “rough.” Lb. 65 cts.; 25 Ibs. \$13; 100 Ibs. \$50.

\section{Divot Mixture}

This is of permanent grasses for fairways and tees and also quick-growing grasses of temporary nature. The temporary grasses grow immediately and fill the scar. Later these are replaced by the permanent grasses. $\mathrm{Lb}$. 65 cts.; 25 Ibs. \$14; 100 Ibs. \$55.

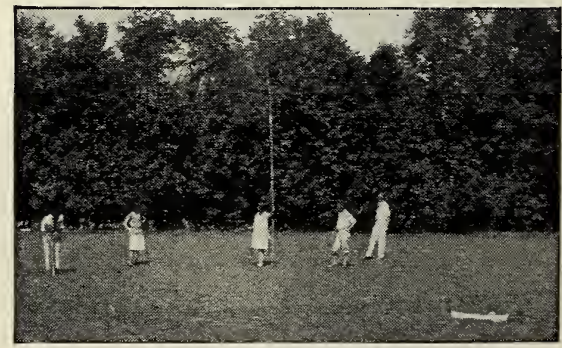

A perfect Putting-Green

We prepay transportation charges on all Lawn Grass Seed Mixtures 


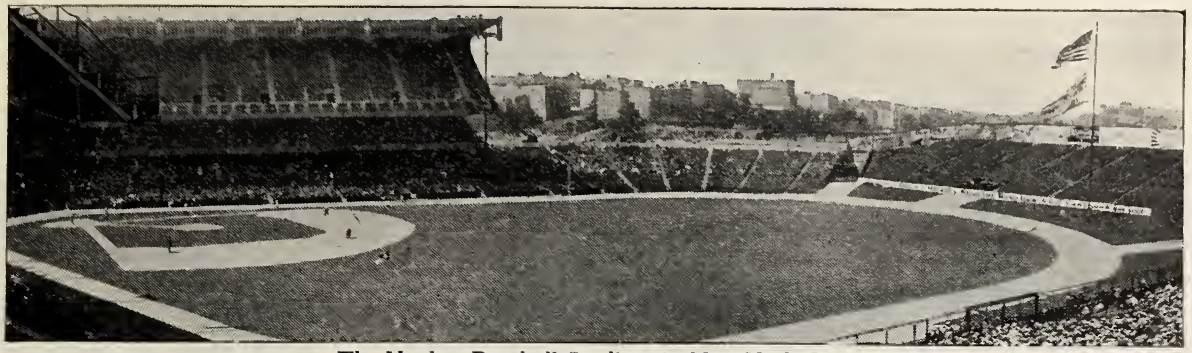

The Yankee Baseball Stadium in New York City

\section{Grass Seeds for Sport}

In field sports, a perfect turf is essential for perfect play. The great variety of grasses of different leaf-texture and rooting character makes it possible to make grass seed mixtures which will produce turf particularly suited for each purpose. The blends offered below are the result of close study and experiment under actual conditions.

\section{Athletic Field Mixture}

This blend produces close, compact and densely matted turf of great resiliency, though free from slipperiness. The grasses are fineleaved, deep-rooting and of an attractive, refreshing green. The seed, if sown under proper conditions, should form a turf ready for mowing in about four weeks from sowing. Use 200 Ibs. to the acre. Lb. 60 cts.; 25 Ibs. $\$ 12.50 ; 100$ lbs. $\$ 45$. Special quotations on large quantities.

\section{Polo Field Mixture}

This special blend of deep-rooting, fineleaved, turf-forming grasses, especially suited for Polo Grounds, forms a thick, strong, enduring turf that will stand any amount of hard usage without showing wear and tear. It grows quickly, and if soil and conditions are at all favorable, with attention to rolling and mowing, should be ready for hard use in eight weeks from sowing. Use 200 Ibs. per acre. Lb. 65 cts.; 25 Ibs. \$14; 100 Ibs. \$50. SpeciaI quotations on Iarge quantities.

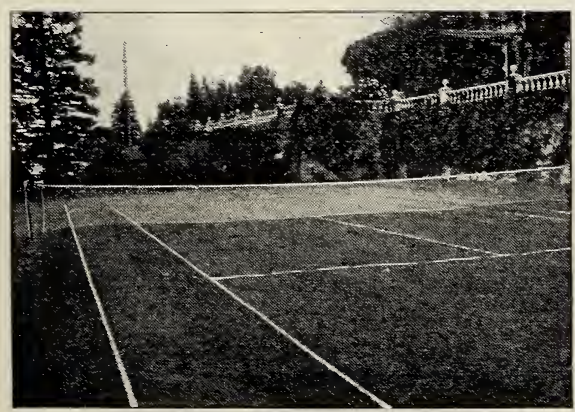

Lawn Tennis Court

\section{Tennis Court Mixture}

The turf required for tennis courts, croquet-grounds, and bowling-greens must be closely interwoven, firm, elastic, smooth, and must stand the wear and tear. This mixture contains the seeds of low-growing, fine-leaved grasses, in proper proportion to form a tough mat of even lawn through the year. Sow at the rate of $10 \mathrm{lbs}$. to 1,000 sq. ft. Lb. 60 cts.; 25 Ibs. \$14; 100 lbs. \$50. Special quotations on large quantities.

\section{Airport Mixture}

A careful survey and study of the turf requirements for Aviation Fields and Airforts have resulted in this special mixture. It is composed primarily of extremely hardy low-growing grasses requiring a minimum amount of mowing. Our mixture is similar to the specifications recommended by the Aëronautics Branch of the U. S. Dept. of Commerce. Sow at the rate of $150 \mathrm{lbs}$. to the acre. Lb. 65 cts.; 25 Ibs. $\$ 13.50 ; 100$ Ibs. $\$ 50$. Special quotations on large quantities.
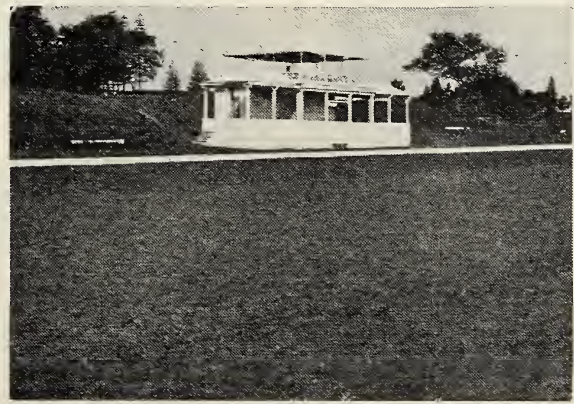

Polo Field

We prepay transportation charges on all Lawn Grass Seed Mixtures 


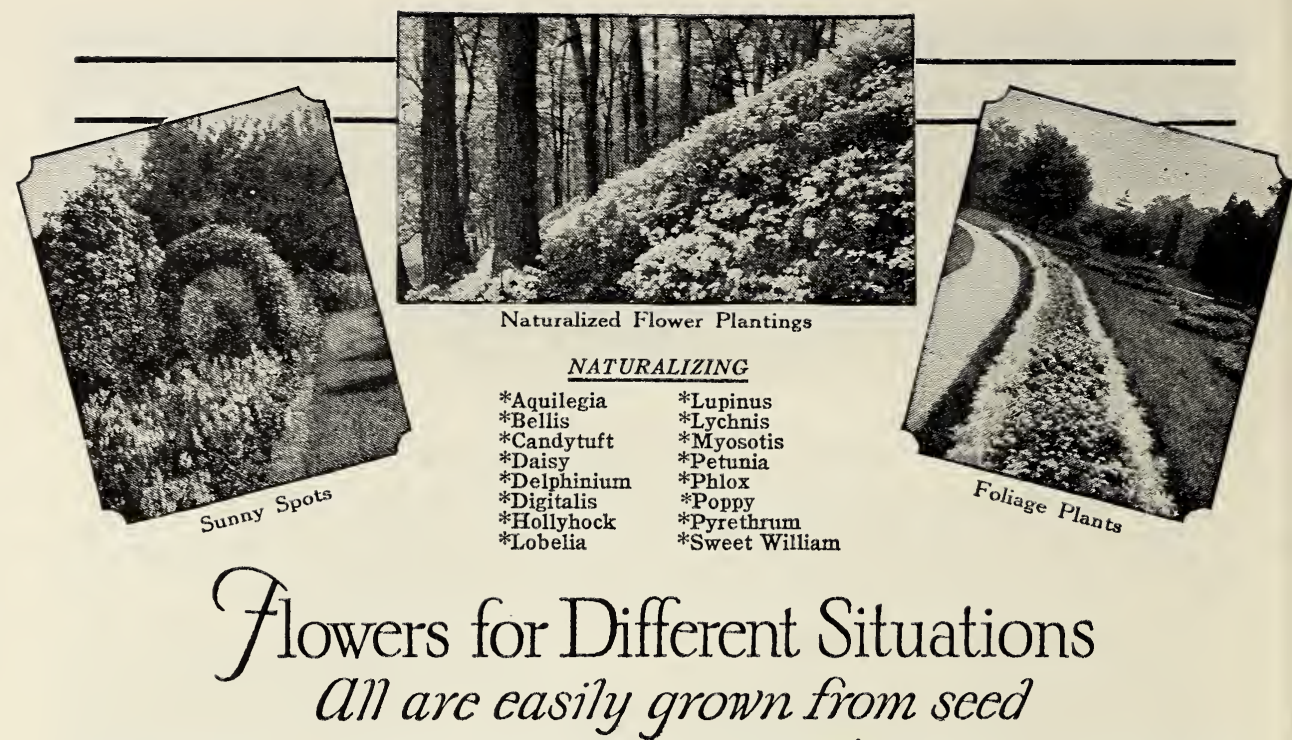

SUNNY SPOTS

Aster

*Achillea

Amaranthus

Balsam.

Calendula

Celosia

Clarkia

Cosinos

Dahlia

Dimorphotheca

Mignonette

* CEnothera

Petunia

Phlox

Portulaca

Salpiglossis

*Sweet William

Zinnia

\section{ROCK-GARDENS}

Abronia

*Alyssum

*Arabis

*Aubrietia

*Candytuft

Ice Plant

*Linaria

Portulaca

*Primula

Torenia

Verbena

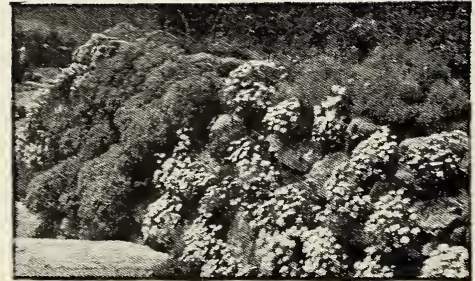

Wall- or Rock-Garden

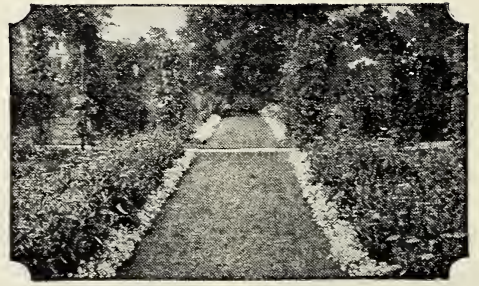

Edgings or Margins
FOLIAGE PLANTS

*Agrostemuma

Amaranthus

Asparagus

Coleus

Dracæna

Dusty Miller

Euphorbia

*Grasses

Kochia

*pyrethrum

Ricinus

Vinca.

\section{MASSED COLORS}

\section{Antirrhinum}

Ageratum

Alyssum

*Arabis

Candytuft

Celosia

Helichrysum

Larkspur

Nasturtium

Petunia

Phlox

Poppy

Portulaca

Salvia

*Sweet William

Verbena

Zimnia

Perennial flowers are indicated by the asterisk (*) 


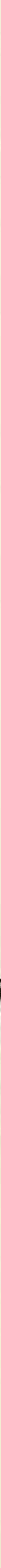

743 BROAD ST., NEWARK, N. J. 

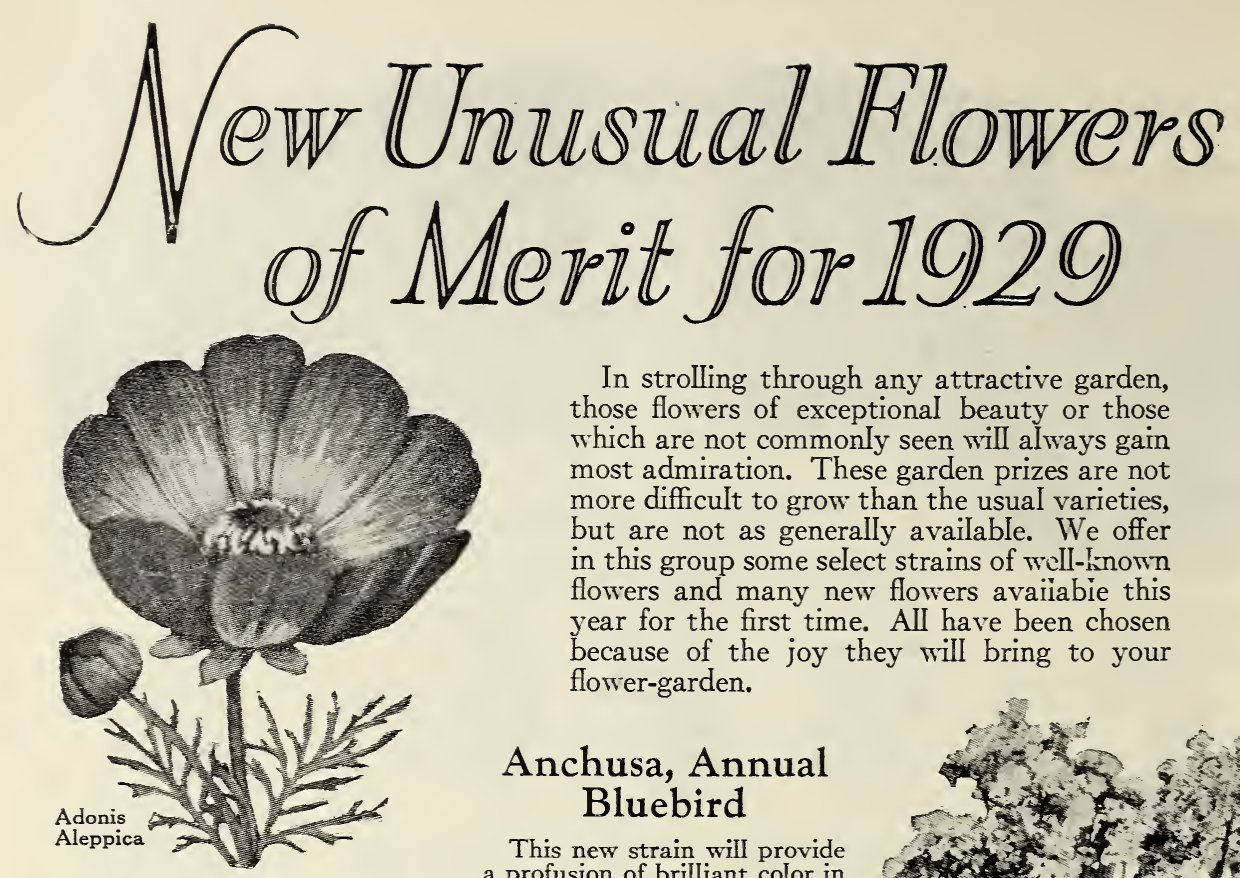

In strolling through any attractive garden, those flowers of exceptional beauty or those which are not commonly seen will always gain most admiration. These garden prizes are not more difficult to grow than the usual varieties, but are not as generally available. We offer in this group some select strains of well-known flowers and many new flowers avaiiabie this year for the first time. AII have been chosen because of the joy they will bring to your flower-garden.

\section{Anchusa, Annual Bluebird}

This new strain will provide a profusion of brilliant color in about ten weeks after the seed is sown. The perennial Dropmore variety has long held its position as one of the most vivid blue flowers known. It must now share this glory with its new annual relative, Bluebird, which lacks the straggly growth of previous annual strains. It grows compactly, $11 / 2$ feet high with a luxuriant bouquet at the top of the plant. The flowers are vivid indigoblue, a needed color among annuals, and are borne through quite a long season. Start the seed in frames in March for July bloom. Pkt. 50 cts.

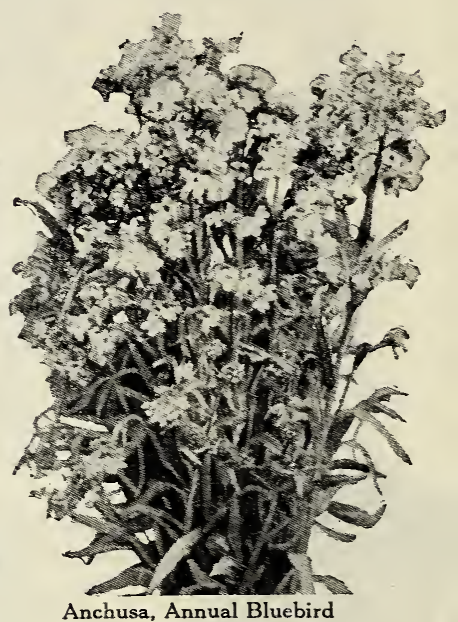

\section{Aster, Ostrich Feather, Coppery Brown}

A brand-new color in this popular class. The large, full flowers, with their long, gracefully curved petals, are fine for cut-flowers. The color varies as the flower develops, first a silky coppery brown, changing to a vermilion-brown with faint whitish petal-tips as the flower ages. Pkt. 50 cts.

\section{Aquilegia, Copper Queen}

A new Iong-spurred Columbine of a welcome color. The petals are of a decided coppery hue and the corolla opens a beautiful buff which slowly fades to a pure white. Pkt. $50 \mathrm{cts}$. 


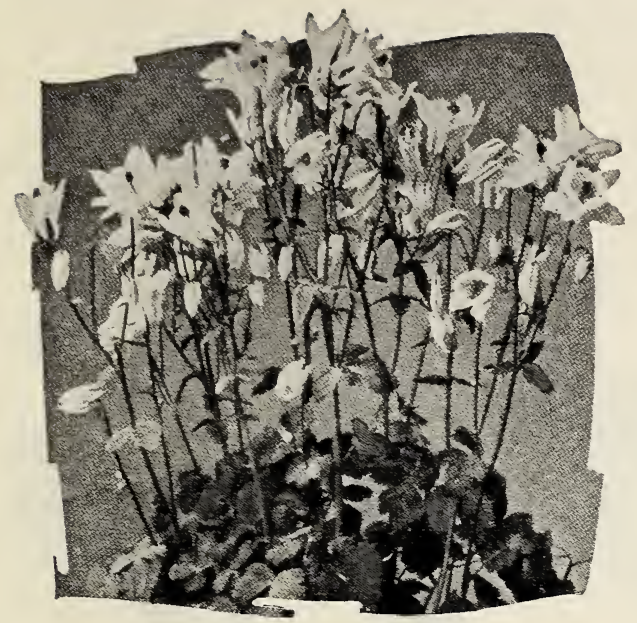

Aquilegia, Edelweiss

\section{Carnation, Perpetual-flowering}

A leading English Carnation specialist has produced this everblooming strain. The seed is selected exclusively from plants which have been grown under glass. The plants will bear about 85 per cent double flowers of rare and delicate colors and color combinations. This is an unusually fine greenhouse strain. Pkt. \$1.

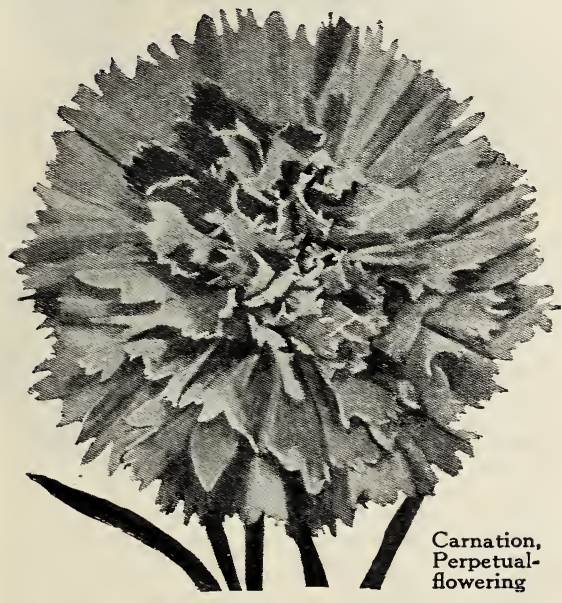

\section{Selected Exhibition Dahlia Seed}

This seed has been selected and saved by an eminent Dahlia originator and specialist, from Dahlias grown in south-central New Jersey, the finest Dahlia country in the world. The greatest care has been used in this selection from varieties which produced such Dahlias as Jersey Beauty, Elite Glory, Elite Peach, Jersey Beacon, Eagle Rock Beauty, Eagle Rock Gem, Jersey Masterpiece, Violet Wonder, Sanihican Nymph and Trentonian. From this seed you may get a true plant of any of these or beautiful variations. Originators select their new varieties from seed of this type. Pkt. \$1.

\section{Aquilegia, Edelweiss}

This wonderful new Aquilegia, growing 16 to 20 inches in height, is covered with pure, snow-white blooms of extra-large size. Because of its earliness and free-flowering tendency, it should have a place in every perennial border. Pkt. 50 cts.

\section{Calendula, Campfire}

This enormous new variety, a brilliant orange with a scarlet sheen and full yellow center, does not show any of the dark center so objectionable in the modern Calendula. Equally worthy as a garden flower or as a forcing subject. Pkt. 35 cts.

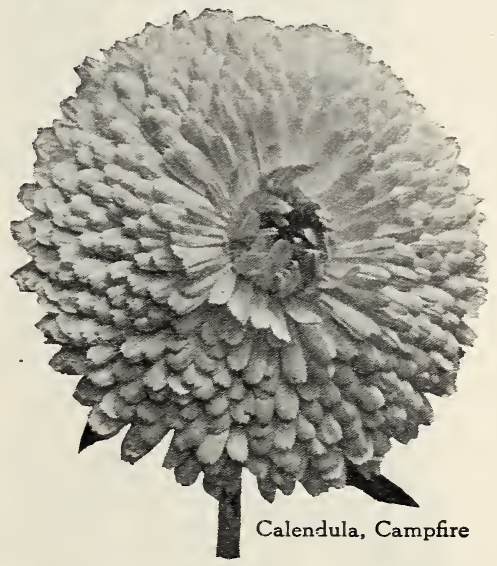

\section{Dahlia, Mignon Hybrids}

In less than three months from seed the dwarf, compact plants 2 feet high, hold a wealth of bloom which will continue until frost. The flowers, resembling single Dahlias, held erect on long, stiff stems well above the foliage, are admirable for cut-flowers and come in crimson, pinks and rose, mauves, scarlet, purple, yellow and white. Plants are suited for bedding purposes. Pkt. 50 cts.

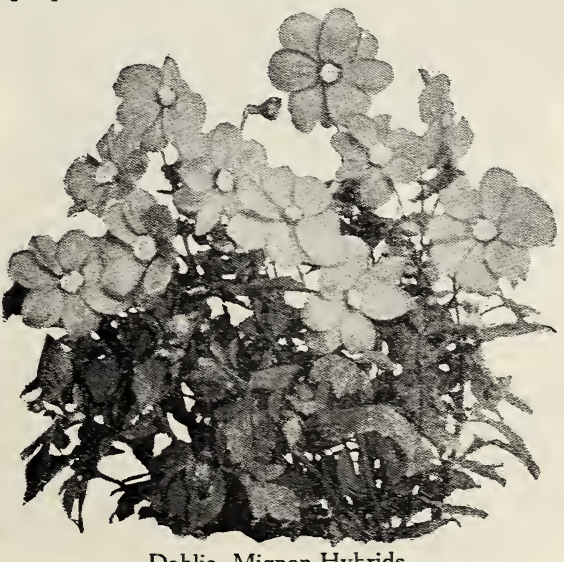

Dahlia, Mignon Hytrids 

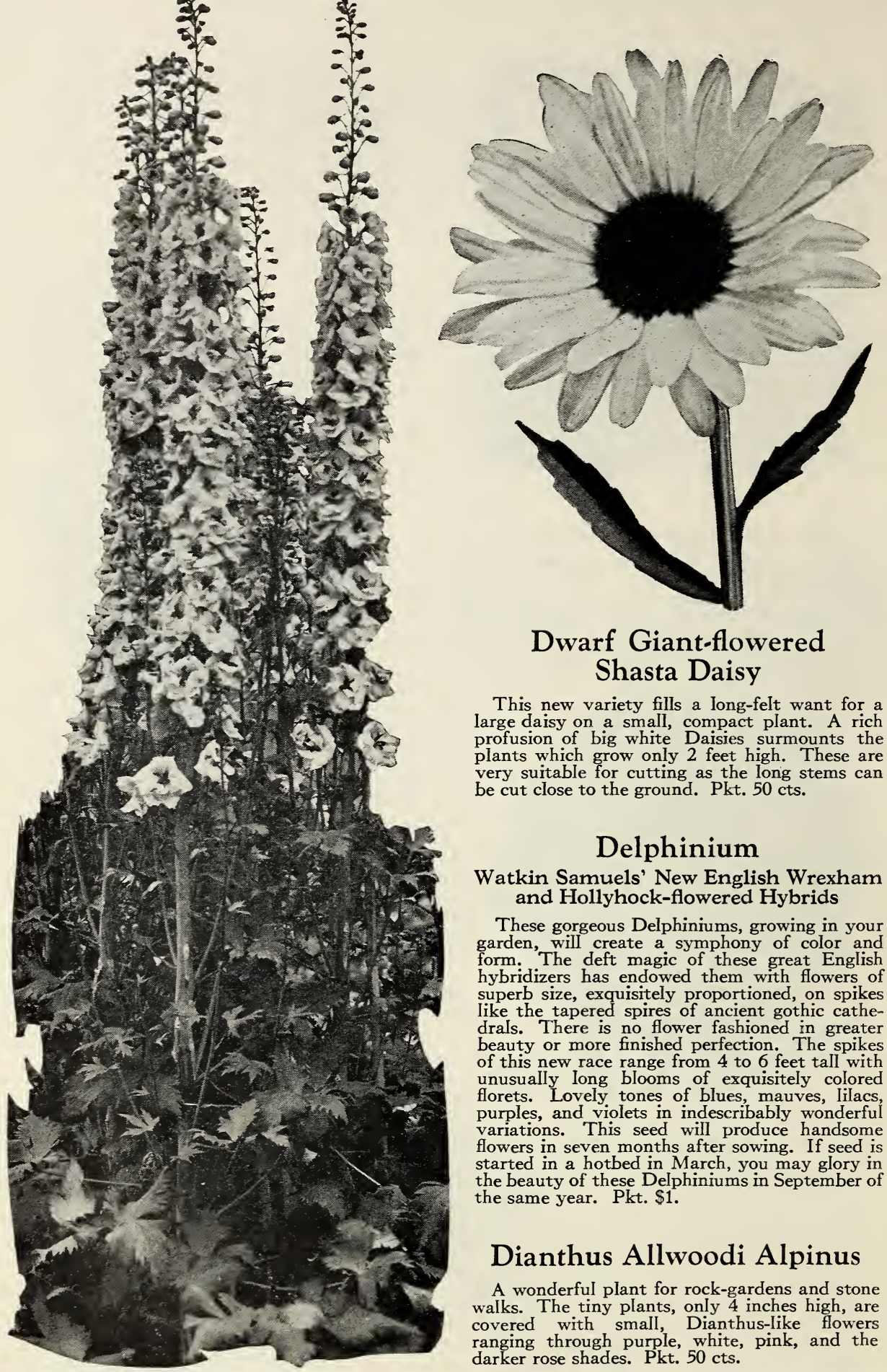

\section{Dwarf Giant-flowered Shasta Daisy}

This new variety fills a long-felt want for a large daisy on a small, compact plant. A rich profusion of big white Daisies surmounts the plants which grow only 2 feet high. These are very suitable for cutting as the long stems can be cut close to the ground. Pkt. 50 cts.

\section{Delphinium}

Watkin Samuels' New English Wrexham and Hollyhock-flowered Hybrids

These gorgeous Delphiniums, growing in your garden, will create a symphony of color and form. The deft magic of these great English hybridizers has endowed them with flowers of superb size, exquisitely proportioned, on spikes like the tapered spires of ancient gothic cathedrals. There is no flower fashioned in greater beauty or more finished perfection. The spikes of this new race range from 4 to 6 feet tall with unusually long blooms of exquisitely colored florets. Lovely tones of blues, mauves, lilacs, purples, and violets in indescribably wonderful variations. This seed will produce handsome flowers in seven months after sowing. If seed is started in a hotbed in March, you may glory in the beauty of these Delphiniums in September of the same year. Pkt. \$1.

\section{Dianthus Allwoodi Alpinus}

A wonderful plant for rock-gardens and stone walks. The tiny plants, only 4 inches high, are covered with smaII, Dianthus-like flowers ranging through purple, white, pink, and the darker rose shades. Pkt. 50 cts. 

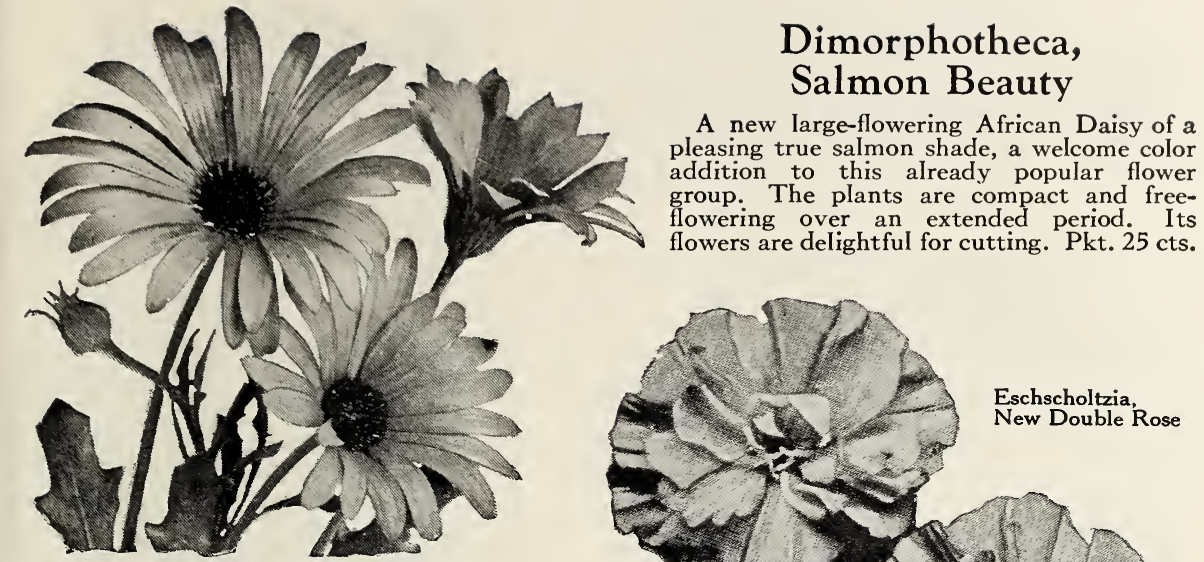

Dimorphotheca, Salmon Beauty

\section{Eschscholtzia, New Double Rose}

This is an unusually good strain of a light rose California Poppy, quite true to color and differing from the usually known variety in being double. Pkt. 25 cts.
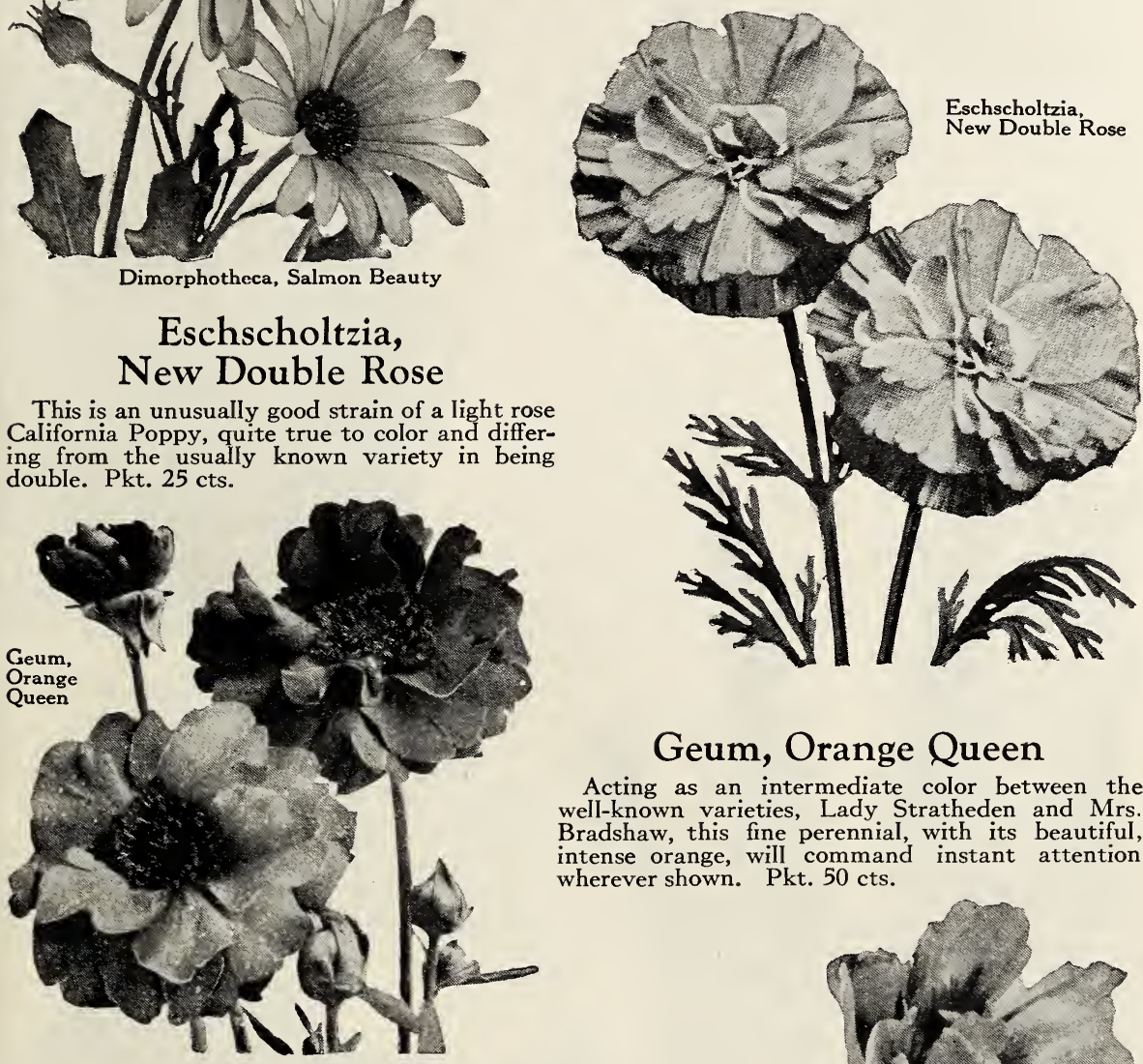

\section{Geum, Orange Queen}

Acting as an intermediate color between the well-known varieties, Lady Stratheden and Mrs. Bradshaw, this fine perennial, with its beautiful, intense orange, will command instant attention wherever shown. Pkt. $50 \mathrm{cts}$.

\section{Godetia, Azalea-flowered, Carminea}

This new variety of the excellent azalea-flowered type is a clear carmine-pink with a pronounced marking. It is not only distinct in color but also comes more double and azalea-like than the varieties previously introduced. We offer this in two habits of growth: Tall type, $21 / 2$ to 3 feet high and the Dwarf type, 18 to 20 inches high. Each, pkt. 25 cts.

\section{Gypsophila elegans, Crimson Gem}

Those who know the beauty of the white Baby's Breath in bouquet arrangements will appreciate the desirability of this new strain. It closely resembles the delicate Annual Baby's Breath but is bright rosy crimson and will contrast beautifully in bouquets of large white flowers. Pkt. 35 cts.

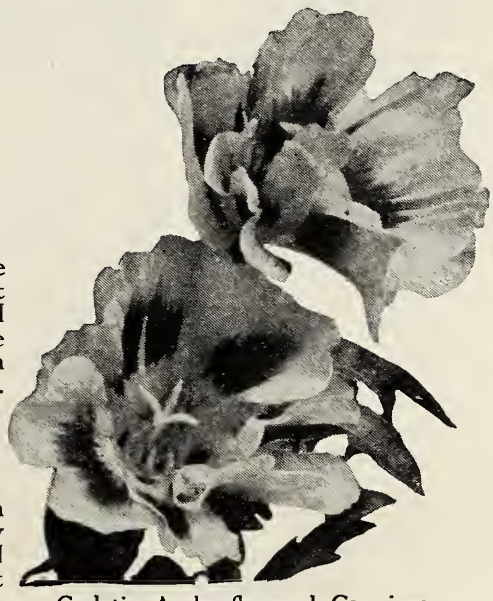

Godetia, Azalea-flowered, Carminea 


\section{Larkspur, La France}

Because of its color, La France bids fair to become the most popular of the annual Larkspurs. Its pleasing salmonpink, a new shade in stock-flowered Larkspurs, will be much prized both for show purposes and for cutting. Pkt. 35 cts.

\section{Lupinus Hybrids, Polyphyllus-Arboreus}

This beautiful new type, the result of crossing $L$. polyphyllus and $L$. arboreus, combines the qualities and characteristics of both and embraces new and rare colors heretofore never seen in Lupines. The plants grow 4 to 5 feet in height in a large, bushy form. It is an excellent perennial plant for the border and an invaluable flower for cutting. Because of its outstanding value it was given the Award of Merit by the Royal Horticultural Society. We offer this unusual strain in six named colors.

Captivation. Soft blue.

Downer's Delight. Deep rose.

Evening Glow. Mauve and yellow.

Queen of the West. Soft primrose.

Seraphine. Mauve and gold.

Zulu. Deep violet-purple.

Each, pkt. 50 cts.; all 6 for $\$ 2.50$

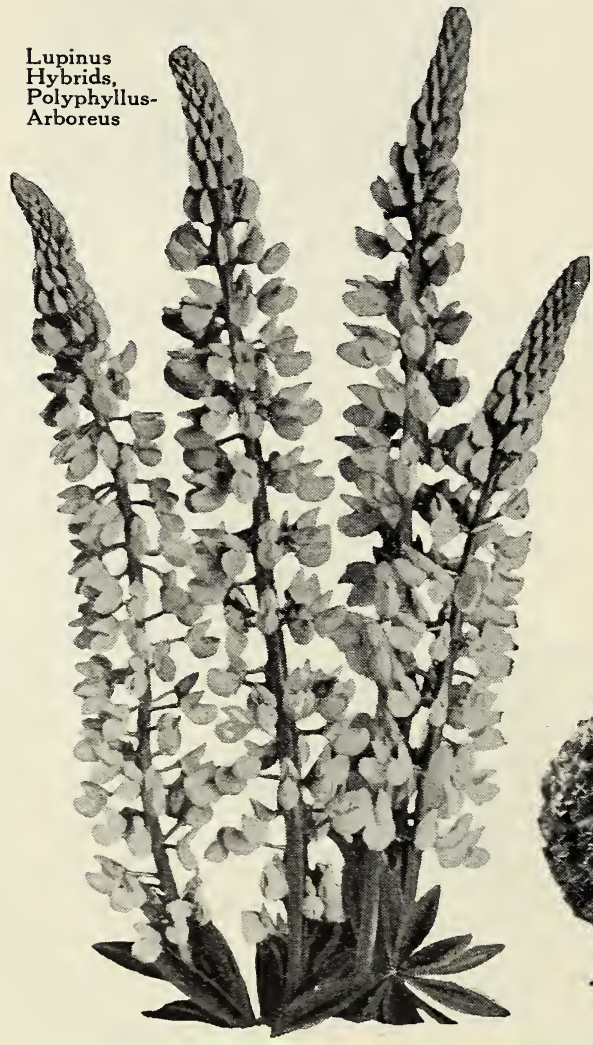

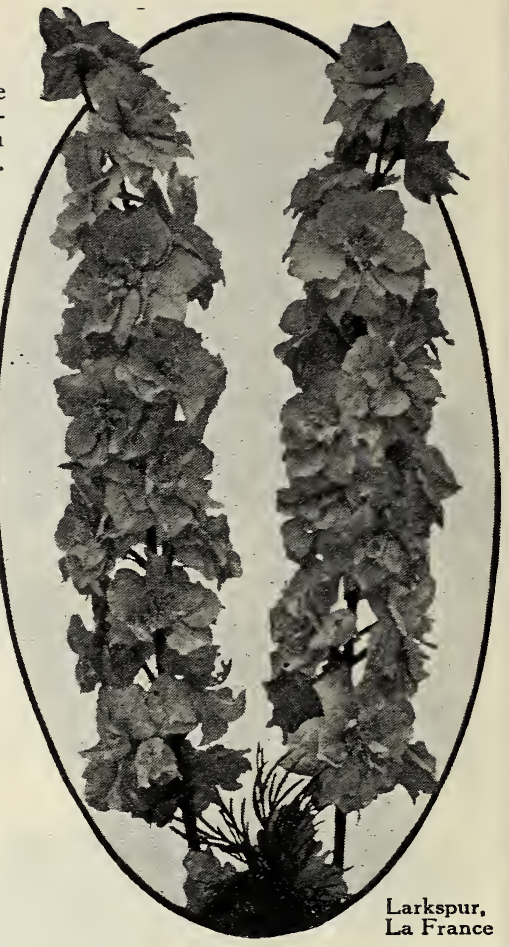

\section{Marigold, Prize Strain Double African}

Because of its great improvement, this strain was given an Award of Merit by the Royal Horticultural Society. It produces bushy plants $21 / 2$ feet high, with enormous flowers, 4 to 5 inches across, of great substance. Prize Strain Orange and Prize Strain Lemon. Each, pkt. 35 cts.; 3 for $\$ 1$. 


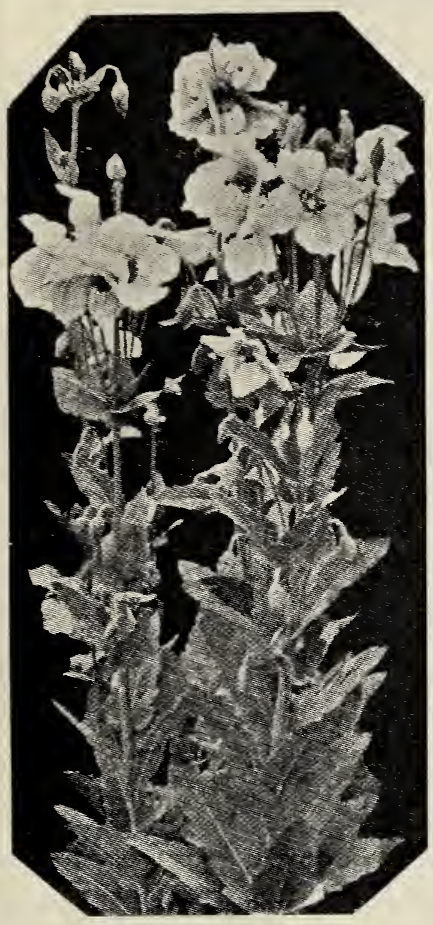

Meconopsis Baileyi

\section{Petunia, Dwarf California Giants}

This is a wonderful strain of single Petunia for pot-culture. It produces very dwarf, comThe huge, fringed single Petunias are beautifully veined on self-colored grounds. It is the best single fringed Petunia for pot culture. Pkt. 75 cts. pact plants, only 4 inches high.

\section{Meconopsis Baileyi}

This new introduction, awarded a First Class Certificate and Special Award of Merit by the Royal Horticultural Society, is a perfectly hardy blue perennial Poppy growing 2 to 3 feet high and freely bearing beautiful sky-blue blooms with golden yellow anthers. It is a flower of very unusual beauty. Pkt. 50 cts.

\section{Nemantirrhinum}

This interesting annual novelty is the result of a cross between Nemesia strumosa and Tom Thumb Antirrhinum, It retains the character of the Snapdragon but embraces all of the colors of Nemesia in combinations such as yellow mottled brown, yellow tigered with red and pink, white suffused with purple and carmine. The flower-spikes are very compact and full because the individual florets occur at closer intervals than is true with Snapdragon.

Erectum Mixed. The plants of this strain grow 12 to 15 inches high and bloom all summer. It is an unusually fine bedding plant. Pkt. 50c.

Gracillimum. These are dwarf, compact plants about 8 inches high, with blooms of a rich violet-purple color. Pkt. 50 cts.

\section{Petunia, Rose of Heaven}

While not a novelty, this is of such outstanding merit that we feel it deserves special mention. It is the dwarf, compact, freeflowering form, with blooms of brilliant rose-pink, 4 to 5 inches across. It is much superior to the best strains of Rosy Morn. Pkt. 25 cts.

\section{Petunia, Violet Queen}

This is remarkable for its true violet-blue color that will not fade when exposed to the sun. The deep-throated flowers are 3 to 4 inches across. It is unexcelled for bedding and makes a splendid combination with Petunia, Rose of Heaven. Pkt. $50 \mathrm{cts}$.

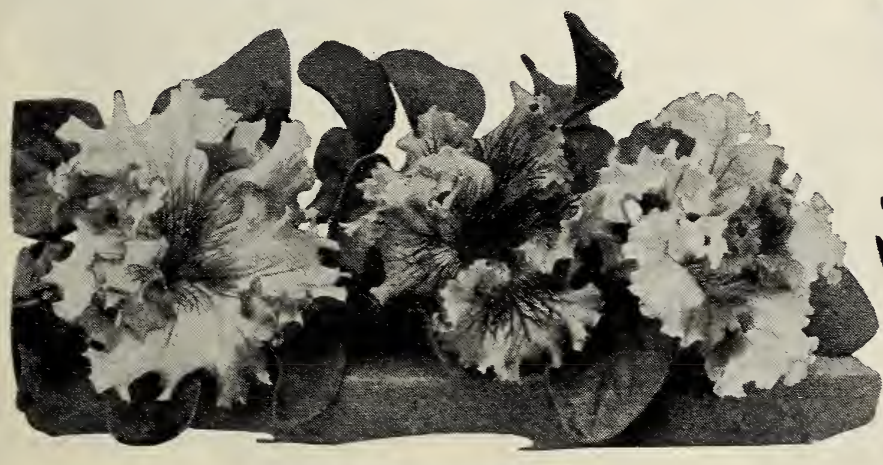

Petunia, Dwarf California Giants

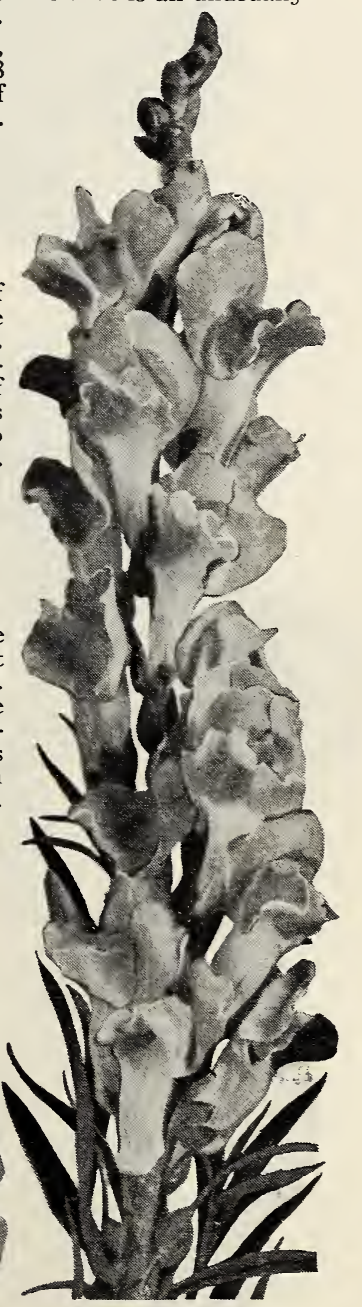

Nemantirrhinum 


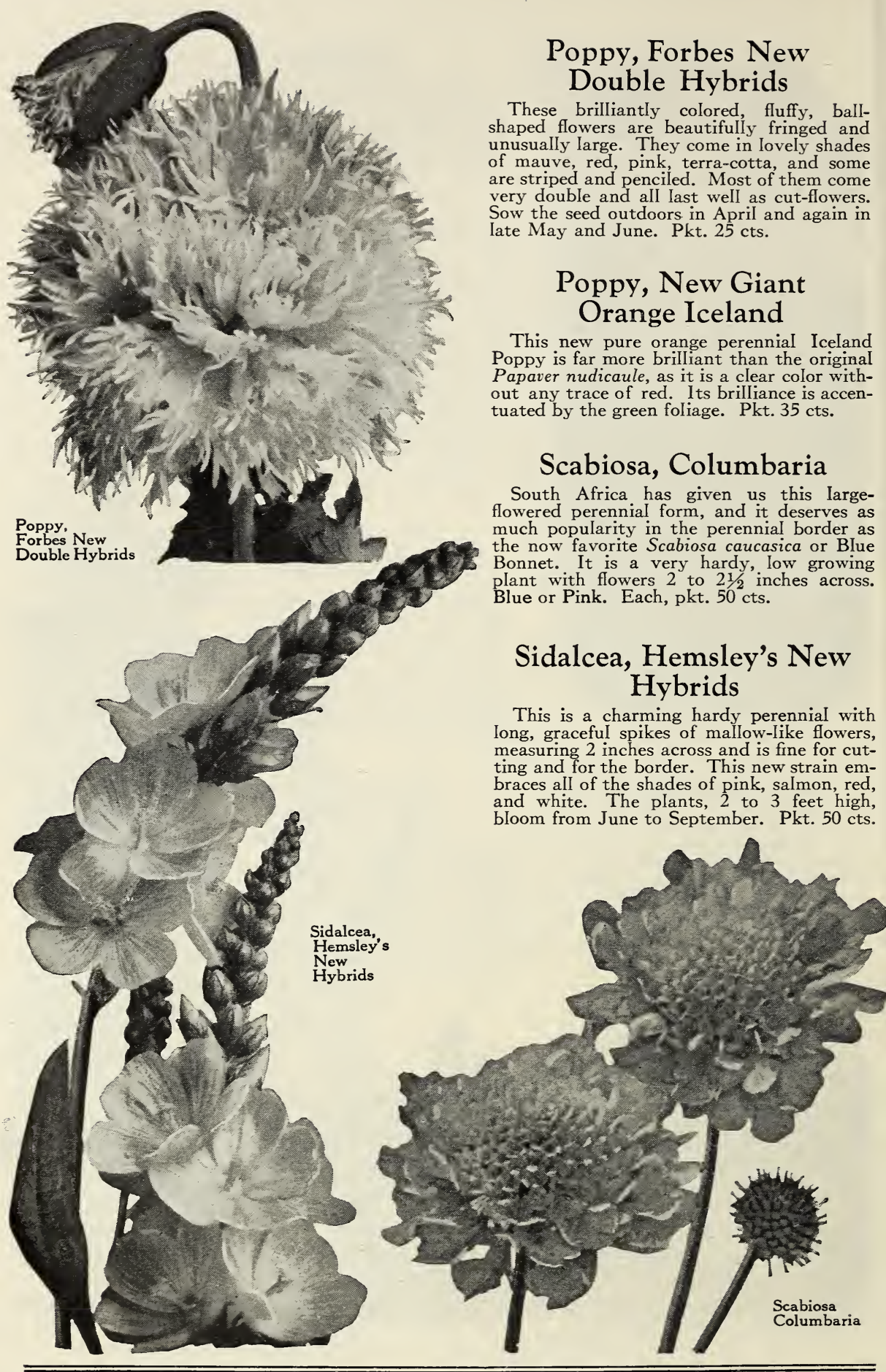




\section{Salvia, America \\ Globe of Fire}

An unusually fine variety and greatly prized for its compact growth. The plants develop into a globe-shaped bush surmounted with a profusion of sturdy flame-red flowerspikes. It is the earliest and the most brilliant of all red Salvias. Pkt. 25 cts.; 5 for $\$ 1$.

\section{Verbena, Royale}

Enormous flower-heads, with individual florets measuring $11 / 4$ inches in diameter, colored rich deep royal blue with a large, creamy yellow eye. Its unusual size makes Royale particularly desirable. Pkt. 35 cts.

\section{Viola, Avalanche}

This new bedding Viola comes perfectly true from seed. It forms a compact, dwarf plant well covered with pure white flowers of good size. Pkt. 50 cts.; 5 pkts. \$2.

The well-known Viola, Jersey Gem, with its deep blue color makes an admirable contrast with Avalanche. We offer Jersey Gem Viola, pkt. 25 cts.; 5 pkts. $\$ 1$.

\section{Single Wallflower, Hamlet}

This Wallflower, the result of a cross between Goliath and Aurora, is of very compact habit and bears exceedingly large bright golden orange flowers. It caused much favorable comment when shown at the Chelsea Show in London. It is a worth-while greenhouse variety. Pkt. 50 cts.; 5 pkts. $\$ 2$.

\section{Lilliput Zinnia, Salmon Rose}

This recent introduction widens the color range of this miniature Zinnia type. The plants grow only 1 foot high with very smaII, globe-shaped flowers which resemble the pompon dahlia. They bloom from June until frost and are excellent for edging or border plants as well as for cutting. Pkt. 25 cts.

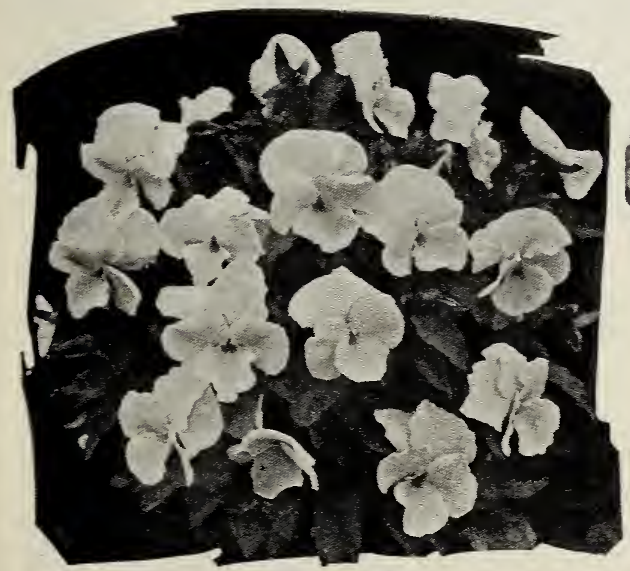

Viola, Avalanche

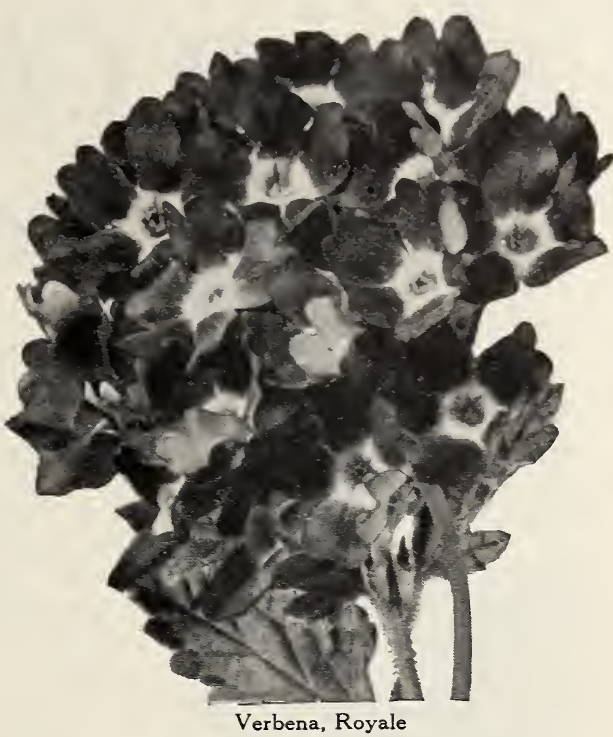

Pansy, Forbes Big Beauties

These are gigantic blooms, often 4 inches across, in wonderful combinations of bronze, silver, gold and copper with wine-red, pink, salmon, silver-grey and brown-beautifully blotched, mottled and bordered, and are of perfect form on stocky plants. Pkt. 75 cts.

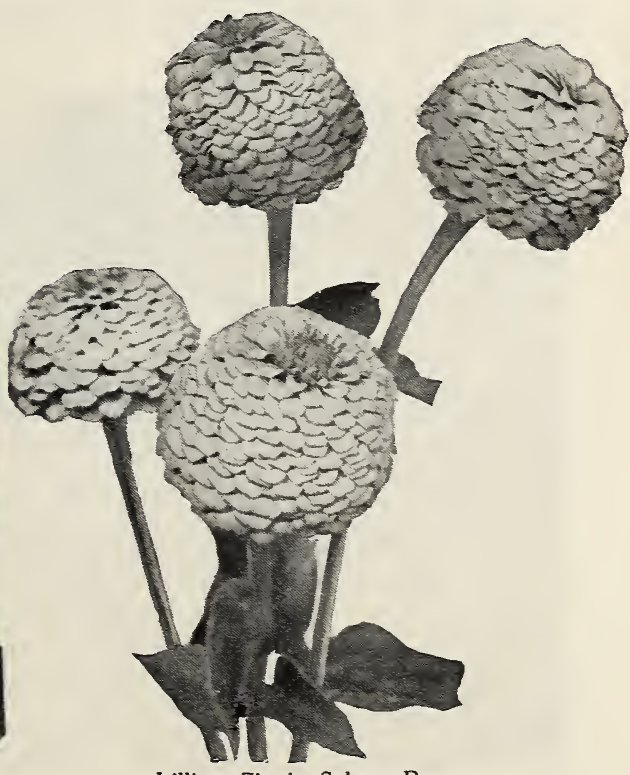

Lilliput Zinnia, Salmon Rose 


\section{Aorbes Choice Seeds of Alnmual Flowers}

NNUALS are flowers which sprout from seed, grow, flower, fruit, and die all within 1 the limits of the garden year. They require the long daylight of summer.

1 They have many advantages. Being inexpensive, they appeal equally to both the home renter and the home owner. They bring a lengthy season of profuse bloom and scent. They are indispensable as filling-in plants in the perennial garden when winterkilling, disease, or natural dying back of bulbs and plants causes wide gaps of earth to mar the effect of the whole. They flaunt their beauty for the garden year and then give themselves up to the work of seeding; many self-sow and are practically permanent. They are fitted for every use, and where there is no ground, Annuals brighten the lives of the city dweller, either in pots or window-boxes and in the garden plots of school children.

Annuals have a delicate beauty all their own and may furnish material for a whole garden or for the cutting border, to supply cut-flowers for home decoration.

Seeds of Annuals unless otherwise noted, should be started indoors in a light, enriched, sifted soil. If clay predominates in the soil, mix it with sand or cinders. Drench the soil of 3-inch flats or of clean, scraped pots with Semesan to sterilize it, so that damping-off, a fungous disease, wiIl not occur. Sow seeds in flats in rows; or in pots in a spiral. Large seeds should be covered with sand to the depth of three times their diameter. Sow each Annual by itself. Fine seeds should be sown in soil that has been watered first and should be covered not with soil but with tissue paper. A sheet of glass over the pot or flat conserves moisture. After the first true leaves appear, first water, pinch back and on a duIlday transplant seedlings, Iater thinning out and weeding so that they do not get spindly.

When sowing outdoors in ground, prepare the soil deeply, enrich and rake well. Water thoroughly once, rather than sprinkle often. Later keep a dust-mulch with a hoe.

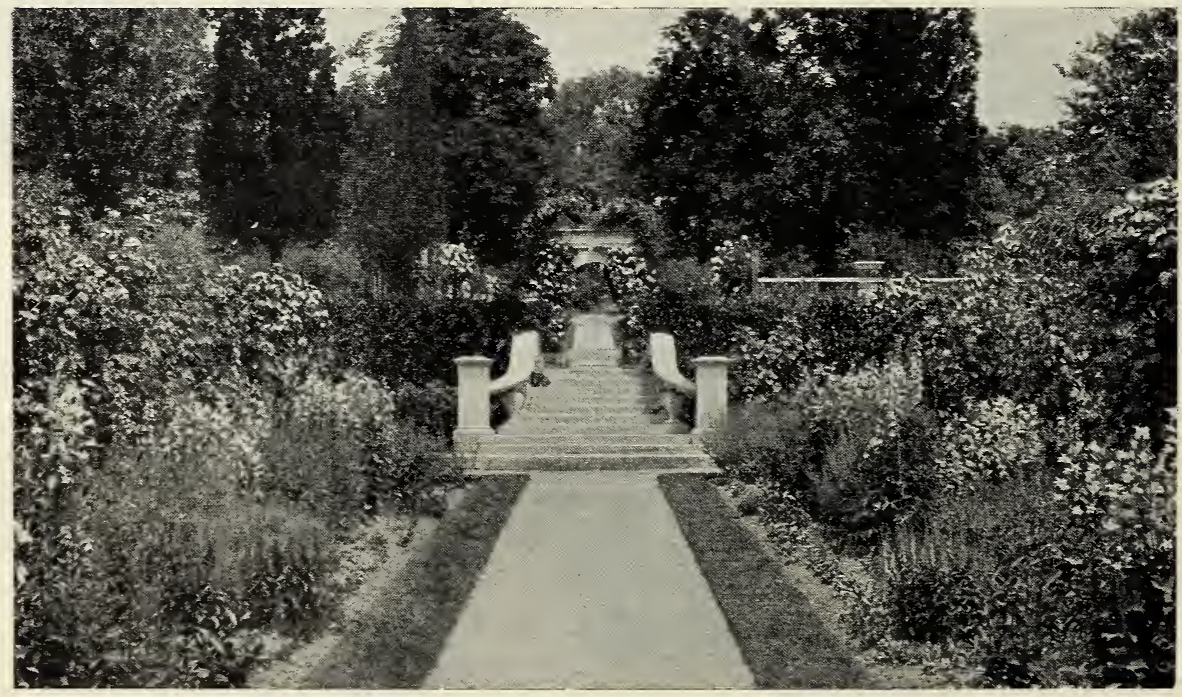




\section{Abronia}

Umbellata grandiflora (Sand Verbena). Half-hardy annual. A charming trailing succulent plant, with verbena-like heads of fragrant flowers of bright rose with white center, aII summer. It delights in a dry, poor soil and sunny situations Peel off husk before sowing seed. Ht. 6 in. Pkt. 10 cts.

\section{Acroclinium. See Everlasting Flowers}

\section{Ageratum - Floss Flower}

One of the best bedding plants, being literally a sheet of bloom from early summer till frost. The flowers are not spoiled by rain, nor do the colors fade. Easily raised from seed started in a hotbed and in May transferred to the garden, 4 to 6 inches apart. Can also be sown outdoors in May.

Blue Perfection. Large heads of deep blue flowers in abundance. Fine for cutting. Ht. 12 in. Pkt. 10 cts.; $1 / 4$ oz. 50 cts.

Lasseauxi. Rose-colored flowers, growing to the height of 1 foot. Pkt. 10 cts.; $1 / 4 \mathrm{oz} .50$ cts.

Little Blue Star. A very dwarf variety used Iargely for edging, growing about 4 to 5 inches high; clusters of bright blue flowers. Pkt. 25 cts.; $1 / 8$ oz. $\$ 1$.

Little Dorrit, Blue. This variety grows about 6 inches high; flowers bright blue. Pkt. 15 cts.; $1 / 4$ oz. 75 cts.

Little Dorrit, White. Same in habit as preceding, only white. Pkt. 15 cts.; $1 / 4$ oz. 75 cts.

\section{Alyssum}

A fragrant edging plant, bearing spikes of small, white flowers in great profusion throughout summer and autumn. Useful for borders or early bedding flowers; fine for baskets and window-boxes. For Alyssum saxatile see Perennial List.

Carpet of Snow. Of creeping habit, forming such a dense carpet of beautiful white flowers that the foliage can scarcely be seen. Ht. 4 in. Pkt. 10 cts.; $1 / 4$ oz. 30 cts.; oz. $\$ 1$.

Lilac Queen. A dwarf, compact variety with pure lilaccolored flowers. Pkt. 10 cts.; 1/4oz. 30 cts.; oz. $\$ 1$.

Little Gem. Pure white; grows only 4 inches high, and blooms profusely. Pkt. 10 cts.; $1 / 4$ oz. 30 cts.; oz. $\$ 1$.

Sweet Alyssum. Of trailing habit; flowers white. Ht. 6 in. Pkt. 10 cts.; $1 / 2$ oz. 25 cts.; oz. 40 cts.; $1 / 4 \mathrm{Ib}$. $\$ 1.25$.

\section{Amaranthus}

Brilliant-foliaged annuals, some of the varieties bearing curious racemes of flowers. AII are usefuI in borders of tall plants, or for the centers of large beds. They thrive best in a hot, sunny location and not too rich soil and must be given sufficient room to develop their fuIl beauty.

Caudatus (Love-lies-bleeding). Light yellowish green foliage; long, drooping, crimson flower-spikes. Ht. $3 \mathrm{ft}$. Pkt. $10 \mathrm{cts}$.

Salicifolius (Fountain Plant). Of graceful drooping habit, with willow-like leaves, 5 to 8 inches long, of bronze-green, changing later to orange-red. Is a native of the Philippine Islands. Sow seed outdoors in May. Ht. $3 \mathrm{ft}$. Pkt. 15 cts.

Tricolor splendens (Joseph's Coat). Brilliant leaves variegated with red, yellow, and green. Ht. $3 \mathrm{ft}$. Pkt. $10 \mathrm{cts}$.

\section{Anchusa Cape Alkanet}

Bluebird. This strain, unlike other annual strains, grows very compactly, 18 inches high, with a luxuriant bouquet at the top of the plant. The flowers are vivid indigo-blue, a needed color among annuals, and bloom through a long season. Start seed in frames in March for July bloom. Pkt. 50 cts. Capensis (Summer Forget-me-not). A hardy annual of more than ordinary beauty. It grows about 2 feet high, branching freely and bearing a profusion of the most lovely azure-blue fiowers, similar in all respects to the forget-me-not, though the blossoms are much larger and of finer color. It blooms early and continues all summer. Pkt. $10 \mathrm{cts}$.; 1/40z. $50 \mathrm{cts}$. For Ancbusa italica, Dropmore, see Perennial List.

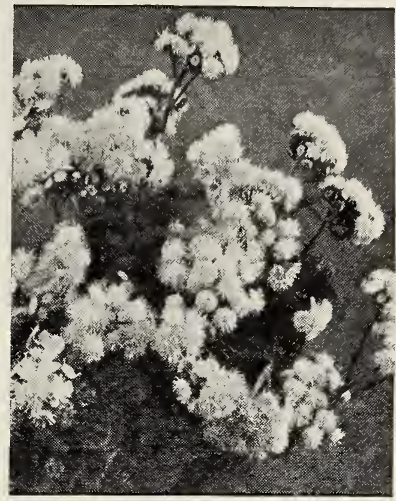

Ageratum. Little Blue Star

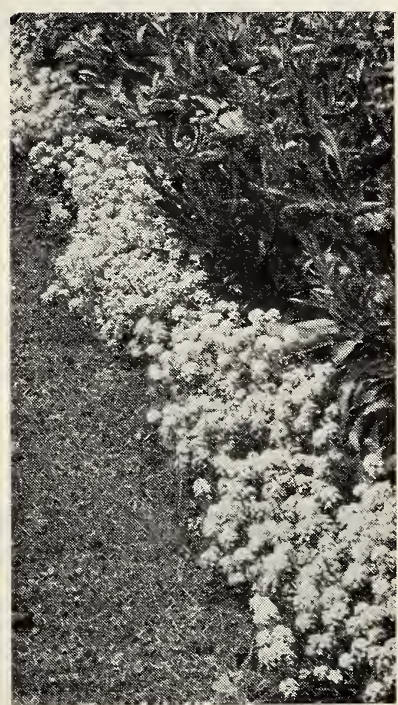

Alyssum. Carpet of Snow

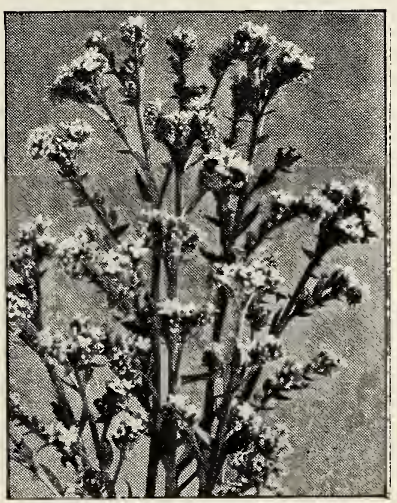

Anchusa capensis 


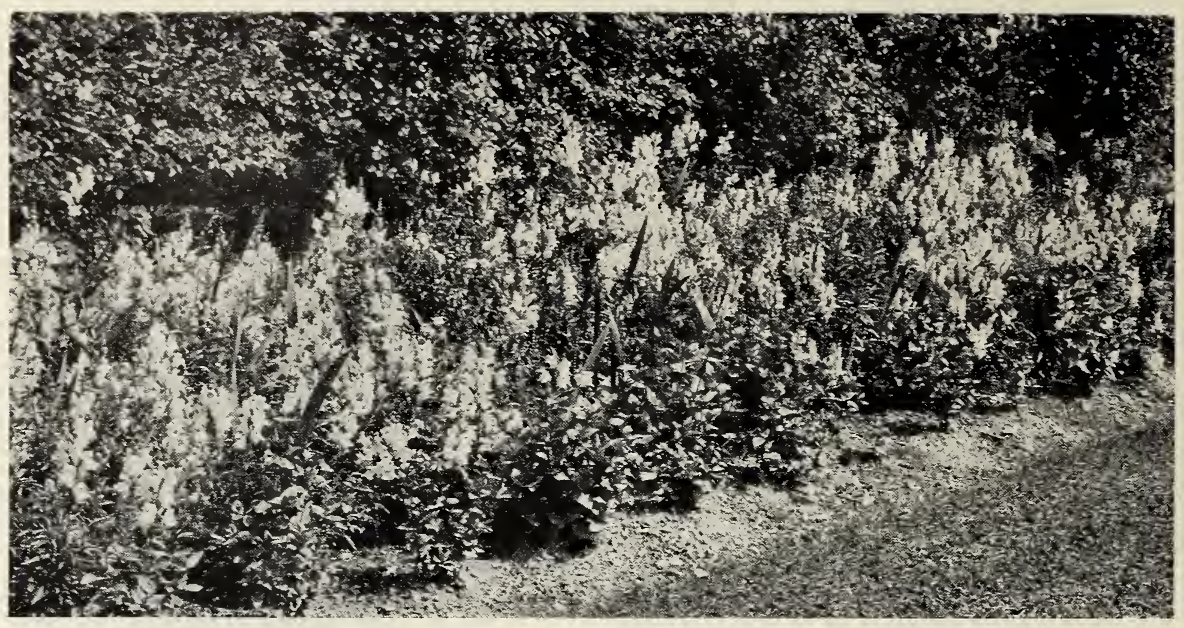

Forbes Super-Giants are the finest type for cut-flowers. To have good straight stems, be sure to put a light stake at each plant of all tall varieties to support the weight of the large blooms.

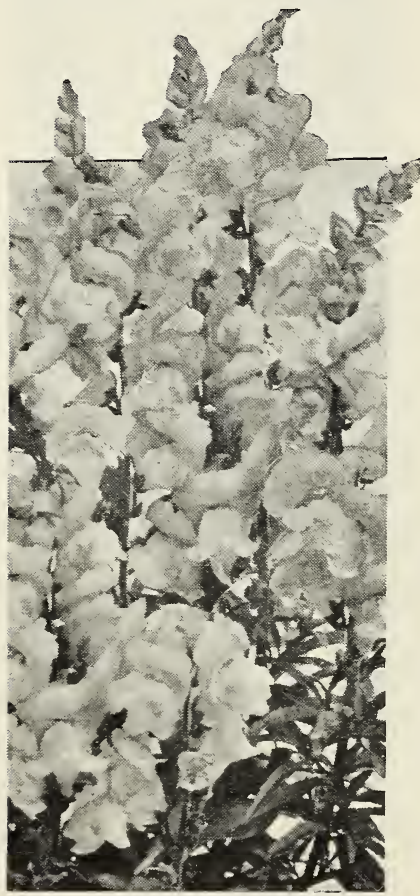

Super-Giant Snapdragons

\section{Forbes Wonderful Snapdragons} (Antirrhinums)

For exquisite form, color, and all-round usefuIness, there are few flowers to compare with the Snapdragons. They are really biennials but bloom freely the first season from seed started in early spring. If cut back and potted up in September, they will bloom nearly all winter, or they may be left outdoors, with some protection, over winter, to bloom again in the spring. For summer flowers, sow the seed indoors in March and transplant to the open ground in May, choosing, if possible, a moist location and cultivating frequently.

\section{Forbes Super-Giants}

This wonderful group of the newest creation in Giant Snapdragons far surpasses anything yet introduced. They grow 4 to 5 feet high, much taller than the Half-Dwarf group, and have still larger flowers, closely placed on the stems. They come in a range of colors that are quite distinct. In vigor of growth, size, color, and profusion of blooms, these SuperGiants are a wonderful improvement over the tall, Iargeflowering strains previously grown.

Apple Blossom. Soft apple-blossom-pink with yellow lip and pure white throat. Strong stems and magnificent flowers.

Cattleya. Beautiful rosy lilac with yellow lip. A very pleasing color and Iarge handsome flowers.

Copper King (Indian Summer). A rich bronzy copper color, with a warm, ruddy sheen. This strain produces magnificent long flower-spikes.

Purple King. Deep, glowing reddish purple or deep garneta very striking shade.

The Rose. Clear deep rose-pink, often called begonia rose. Very large individual flowers set closely on long spikes.

Wallflower. Very Iarge, bronzy orange flowers, shading to coppery red at the edges and deep yellow in the throat. Mixed. Provides a fine assortment of color combinations.

Each, pkt. 25 cts.; $1 / 80 z . \$ 1$

COLLECTION: Pkt. of each of the above 6 varieties for $\$ 1.25$;

$1 / 80 z$. of each of the 6 for $\$ 5$

\section{Tom Thumb Varieties}

Mixed Colors. The varieties in this mixture are fine for bedding, and grow about 10 inches high. Pkt. $10 \mathrm{cts}$; $1 / 8 \mathrm{oz}$. 35c. See Greenhouse Seeds on page 64 for forcing Snapdragons. 


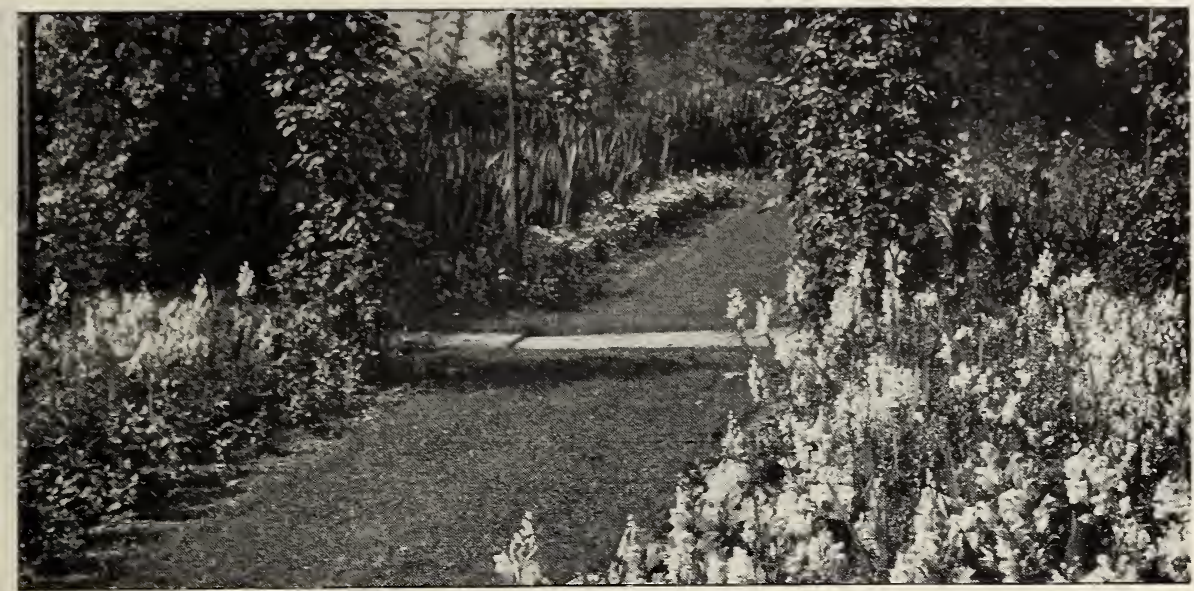

\section{Half-Dwarf Giant-flowered Snapdragons}

The Glory varieties of Half-Dwarf Giant-flowered Snapdragons are the best for bedding. They come in a wonderful array of soft color combinations and can be flowered from seed the first year if sown indoors in March. Ht. $11 / 2 \mathrm{ft}$.

Autumn Glory. Very brilliant apricot-buff, with yellow center, producing a rich glowing effect when massed in borders. Crimson Glory. This has large flowers of a rich, velvety crimson, quite free from any trace of the generally disliked magenta tint. The compact plant blooms early.

Lilac Glory. BeautifuI, half-dwarf, silvery Iilac sort.

Mauve Glory. Extremely Iarge flowers of a lovely rosy mauve.

Orange Glory. This variety grows to a height of 12 to 15 inches, is of very sturdy habit, and bears large, beautifully formed flowers of rich orange, shading to gold in the center.

Pink Glory. A charming variety, described as an almondblossom-pink. The flowers are large and borne on fine, upright spikes. Makes a splendid effect in beds.

Salmon Glory. The general effect in masses is a rich, salmonred, or terra-cotta shaded salmon, the individual flower being a deep salmon-rose above, a vivid orange in the center, merging into terra-cotta in the base.

Sunrise Glory. The largest variety, in a rich, terra-cottaorange, shading to yellow in the center.

White Glory. A very fine, half-dwarf, pure glistening white.

Glory, Mixed. Comprises a very wide range of colors including all of the varieties above mentioned. $1 / 80 z$. $\$ 1$; oz. $\$ 5$.

Each, pkt. 25 cts.; 1/80z. $\$ 1$

COLLECTION: One pkt. of each of the above 9 varieties for $\$ 2$

\section{Semesan Seed Disinfectant}

Mix a small quantity of Semesan powder with your Snapdragon Seeds before sowing - a teaspoonful to one ounce of seed, a pir ch to a packet - shake together a minute and sow. Protects against fungus and disease.

\section{Arctotis - African Daisy}

Grandis. A remarkably handsome annual which forms bushes 2 to 3 feet high and blooms in a sunny location from July until frost. Its flowers are large and showy, being pure white on the upper surface, embellished with a narrow yellow zone at their base; the reverse of petals is pale lilac-blue. Sow seed outdoors in April. Pkt. 15 cts.; $1 / 4$ oz. 50 cts.
Beds of mixed Snapdragons look well edged with Sweet Alyssum; pink shades are best with Ageratum, and the orange and apricot shades with dark blue Lobelias. Give them deep, rich soil, plenty of water, and a location which is shaded part of the day. Do not cultivate them after the plants are big enough to touch each other.

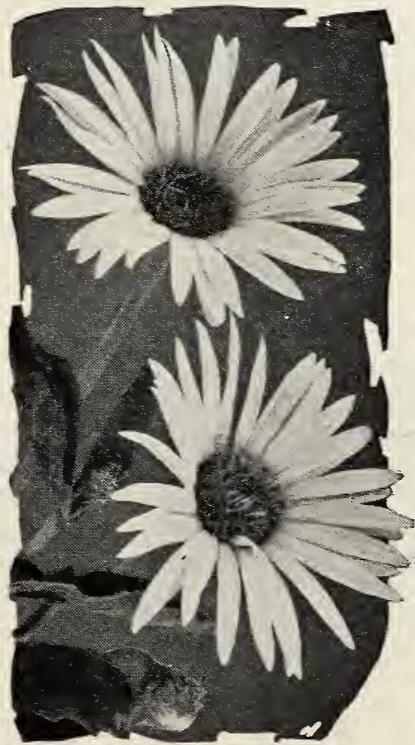

Arctotis 


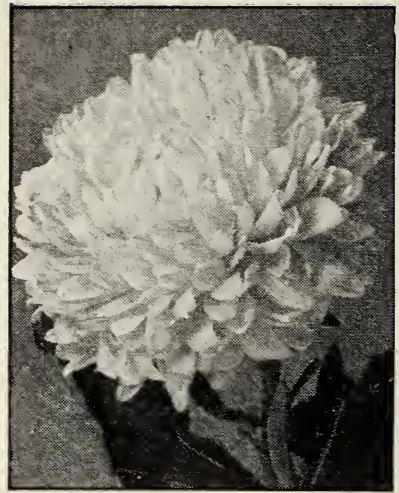

Branching Aster

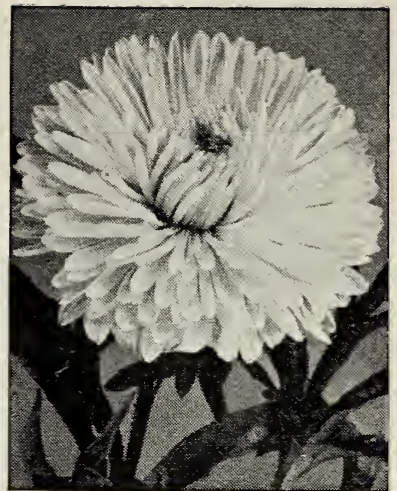

Royal Aster

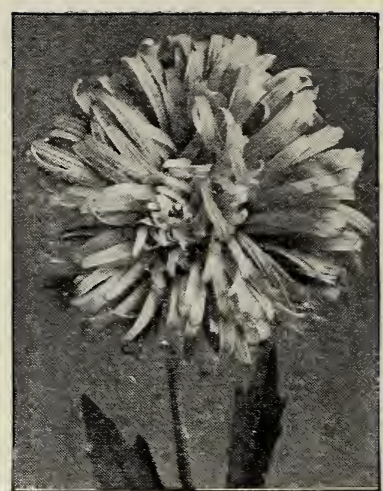

Astermum. See page 26
While all Asters are very beautiful, the variation in the shape of the flowers is remarkable. On this and the next page we show pictures illustrating seven of the most important types, any of which may be had in almost the full gamut of Aster colors. Besides, they vary in habit of plant, earliness and Iateness of flowering, and the size of individual blooms. While their beauty is, as a rule, best appreciated as cut-flowers, they make showy masses of color in the garden, especially those early branching types with the erect, shortrayed, incurved flowers.

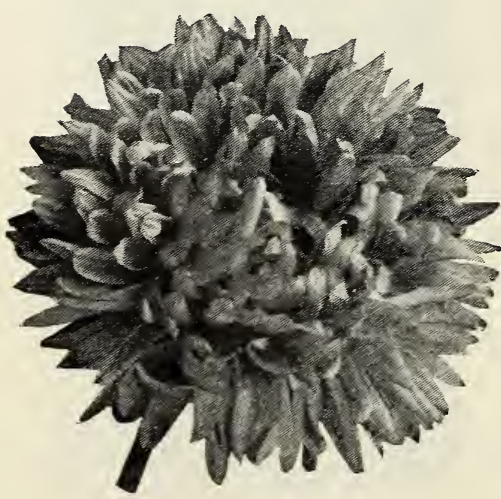

Heart of France

\section{Aster-Queen of the Annuals}

The Aster is the most popular annual fall flower grown, and justly so because of its easy culture, season of bloom, and lasting qualities, both in the garden and as a cut-flower. To cut Asters abundantly as long as possible, several sowings should be made of the early, midseason, and late-flowering types. To succeed with Asters sow the seed in flats in the house or hotbed in March; transplant the seedlings 2 inches apart in boxes, when they are large enough to handle; and move to permanent beds in May. Make the second sowing in the coldframe the latter part of April, and the third the latter part of May. Set the plants of early varieties 10 inches apart, and of later varieties 18 inches apart. The richer the ground the better your flowers will be, and water is very necessary.

\section{Forbes Branching (Blight Resistant)}

This superb strain forms strong, branching bushes, 2 to 3 feet high, bearing on long, strong stems their handsome chrysanthemum-like flowers. These large, fluffy blooms-the Iargest of all the Asters-are double to the center, of exquisite form and delicate color, and the petals broad and undulating. They bloom usually at their best during September. White, Lavender, Shell-Pink, Crimson, Purple, Pink Enchantress, and Mixed. Each, pkt. 10 cts.; $1 / 8$ oz. 40 cts.

\section{Special Collection Offer}

Of Forbes Branching Asters in 6 colors. One pkt. of each colorWhite, Lavender, Shell-Pink, Crimson, Purple, and Pink Enchantress-all beautiful shades and easy to grow- 6 pkts.) for $50 \mathrm{cts}$.; $1 / 80 \mathrm{oz}$. of each of these 6 colors for $\$ 2$.

\section{Heart of France}

This beautiful variety opens red as the purest ruby, deepens with age, and retains its remarkable color till frost. The petals appear strikingly changeable, at one time showing a glow and sheen quite unique, and at another a soft, warm, velvety texture. In any light, Heart of France commands instant admiration. The flowers are large and full, the plants of branching type and robust habit and the stems are long with few laterals. Ht. $1 \frac{1}{2}$ to $2 \mathrm{ft}$. Pkt. $25 \mathrm{cts}$; $1 / 8 \mathrm{oz}$. $75 \mathrm{cts}$.

\section{Royal}

One of the best early-flowering sorts similar in type of flower to Forbes Branching. Very desirable for beds or borders and excellent for cutting. Lavender, Rose, Purple, Shell-Pink, White, and Mixed. Each, pkt. 15 cts.; $1 / 8$ oz. 60 cts. 


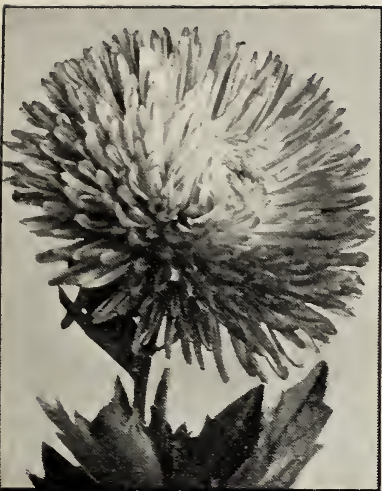

King Aster

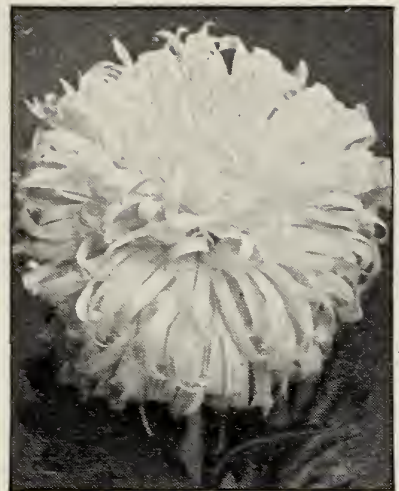

California Giant

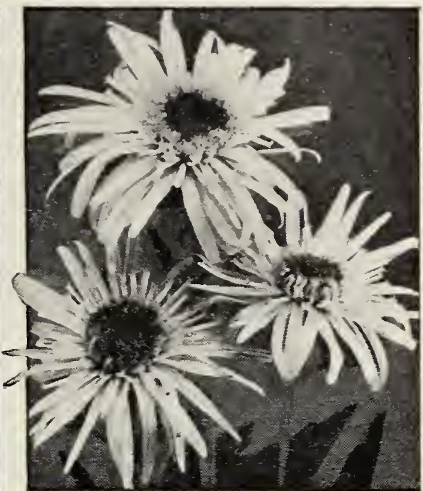

Sunshine Asters

\section{King Aster}

This magnificent class of Asters is distinct from all others in the character of the flower. The petals are Iong, narrow, and folded lengthwise, as if quilled, giving a very graceful and charming effect. Flowers are of great size and substance and last longer when cut than any other class. The plants are large and the stems unusually long. They come into bloom after the early sorts and before the branching types. In seven handsome colors: Lavender, Lavender-Pink, Shell-Pink, Violet, Crimson, Rose, White, and Mixed. Each, pkt. 20 cts.; $1 / 80 z .75 \mathrm{cts}$.

\section{American Beauty}

This beautifuI variety is, beyond doubt, one of the grandest sorts in cultivation. It is of the Late Branching type, 2 to $21 / 2$ feet high. The flowers, from 4 to 5 inches in diameter, are fuII, with incurved petals, and on stems from 15 to 20 inches long. Shell-Pink, Deep Rose, White, Lavender, Purple, and Mixed. Each, pkt. 15 cts.; $1 / 8$ oz. 60 cts.

\section{New Sunshine Aster}

You will be impressed and delighted with the striking beauty of this new Aster. The flowers, which measure from 4 to 6 inches in diameter, are half-double and exhibit all the grace and beauty of the single Aster, greatly enhanced by a cushion center of tiny quills of a contrasting color. The golden yellow ground-tone of the quilled petals contrasts wonderfully with the pink, blue, lilac, and white of the outer petals. These form a loosely curled circle, making the flowers extremely pleasing to the eye. The plant is of branching habit similar to Forbes Branching, throwing long stems which make it invaluable as a cut-flower. The delicate beauty and high value of this Aster should appeal to every garden-lover who wants really fine flowers for cutting. Blue, Pink, Lilac, and White. Each, pkt. 25 cts.; 5 pkts. \$1.

Sunshine Aster Mixed. Contains pink, mauve, dark blue, dark red, and pastel shades from white to coral-pink, and clear mauve to silver lavender. Pkt. 25 cts.; 5 pkts. \$1.

\section{California Giants}

In this splendid cut-flower strain, the earliness and the beautiful fluffy Comet type of flower of the Crego Asters is combined with the giant size and vigor of the American Beauties. The flowers are full-centered and substantial, averaging 5 to 6 inches across, and produced on stout stems $11 / 2$ to 2 feet long without disbudding. Ht. 3 to $31 / 2 \mathrm{ft}$. Peach Blossom, Light Purple, Deep Rose, Dark Purple, Light Blue, White, and Mixed. Each, pkt. 25 cts.; $1 / 8$ oz. 75 cts.
Asters like good soil, sunshine, and ample supplies of water, although the ground must not be soggy. Cultivate them weekly, taking care not to disturb their roots while they are small, but cease cultivation as soon as the plants touch each other. If extra-fine blooms are wanted for exhibition or cutting, disbud the plants, leaving only one flower to the stem, and feed them with copious supplies of weak liquid manure. For garden display, such attention is unnecessary, and they may be left entirely alone after they become large enough to shade the ground.

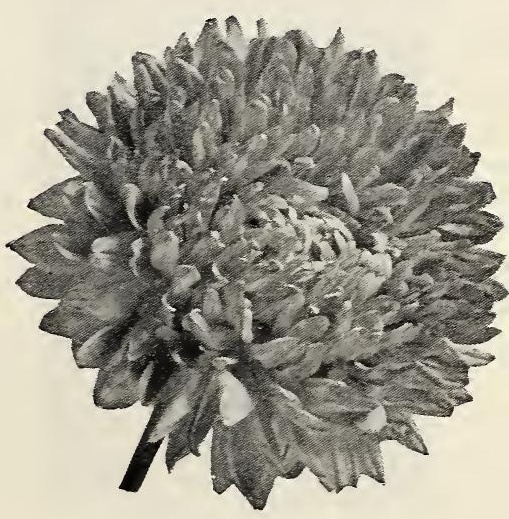

American Beauty 


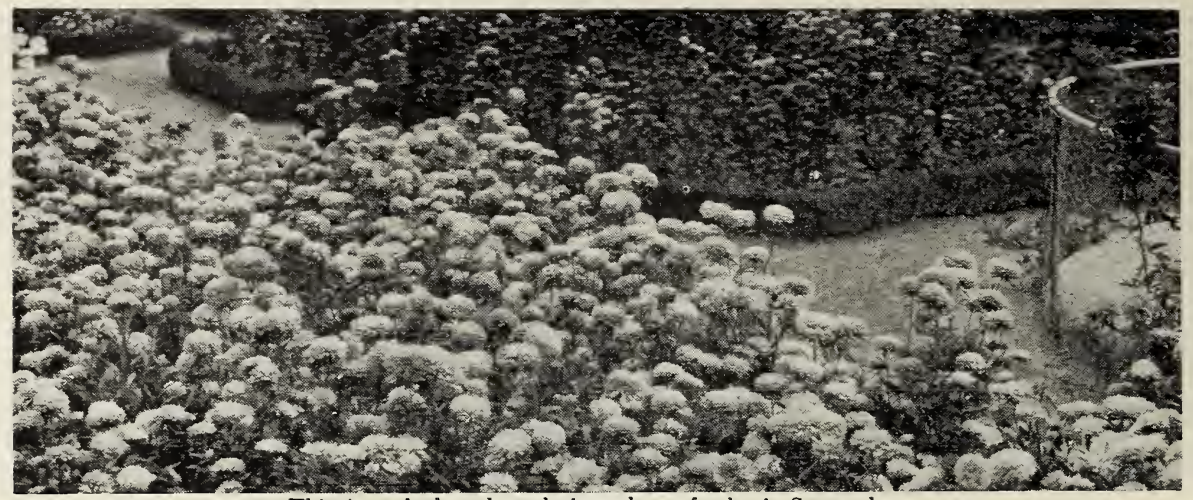

This Aster bed made a glorious show of color in September

BaIsams are very useful for filling in vacant places. They grow and bloom quickly from seed, and may be transplanted bodily to a location where they are needed even when fully grown and in the height of bloom.

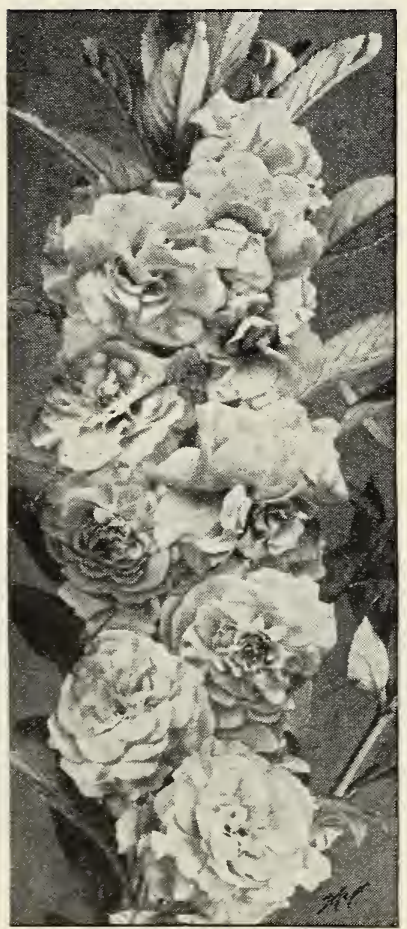

Double-flowered Balsam

\section{Ostrich Feather Asters}

This is considered to be the finest and Iargest of all the Comet type. The flowers are borne on long, stiff stems and are of a fluffy character, frequently 5 inches in diameter. Because of their keeping qualities, they are fine for cut-flowers as weIl as bedders. Large, full flowers, with long, beautifully curled, shaggy, twisted petals. Ht. $11 / 4 \mathrm{ft}$. Maroon, White, Blue, Rose, and Mixed. Each, pkt. 10 cts.; $1 / 80 z$. 40 cts.

Coppery Brown. A brand-new color in this class, especially fine for cut-flowers. The color varies with the development of the flower, first a silky coppery brown, changing to a vermilion-brown with faint whitish petal-tips as the flower ages. Pkt. 50 cts.; 5 pkts. $\$ 2$.

\section{Forbes Astermums}

The plants are tall, graceful, strong and branching. The flowers are very large, often 5 inches across, of great substance, on long, sturdy stems. Excellent for beds or massing. Ht. $11 / 2 \mathrm{ft}$. White, Light Blue, Scarlet, Peach-Blossom, and Mixed. Each, pkt. 15 cts.; $1 / 8$ oz. 60 cts.

\section{Single Annual Asters}

Popular for cutting, the flowers are carried on long stems and much resemble the single Japanese chrysanthemum. Our strain has long petals and a very small center.

Pink Pearl. A fine pink variety. Pkt. 15 cts.; 1/8oz. 60 cts. Violet Queen. An excellent violet bedding variety. Pkt. 15 cts.; $1 / 8$ oz. 60 cts.

\section{Semesan Seed Disinfectant}

Mix Semesan powder with your Aster Seeds before sowing-a teaspoonful to one ounce of seed, a pinch to a packet-shake together a minute and sow. Protects against fungus and disease.

\section{Balsam · Lady's Slipper}

These favorite half-hardy annuals are easy to grow, but love hot summer sun, rich soil, and plenty of water. The young plants are quick, sure growers and, from seed sown in the open ground in May, soon form handsome bushy plants $11 / 2$ feet high, thickly massed with large, rose-like flowers. Transplanting dwarfs plants and makes flowers more double.

Double Camellia-flowered. The finest type of Balsam. Very large, extra-double camellia-like flowers in many colors and shining green foliage. They are splendid for bedding. Pure White, Rose, Yellow, Scarlet, Lavender, and Mixed. Each, pkt. 10 cts.; $1 / 4$ oz. 50 cts. 


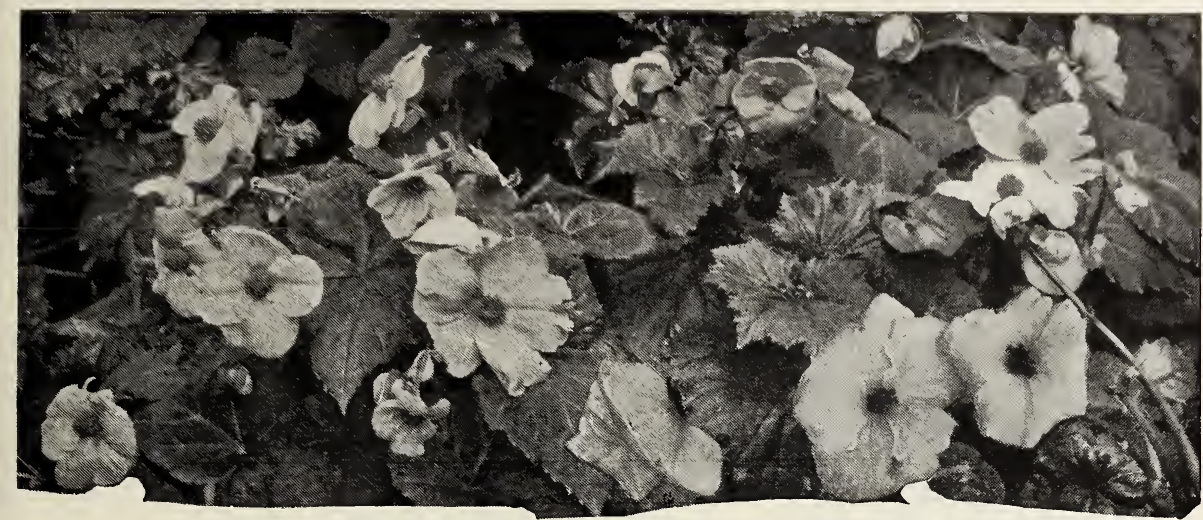

Single Tuberous-rooted Begonias contrast nicely with the beautiful foliage

\section{Begonia}

The following varieties of Begonia semperflorens and B. gracilis take rank as bedding plants with geraniums and coleus, doing equally well in fuII sunlight, and surpassing both in positions partially or wholly in shade. They are of sturdy growth, growing about 1 foot high, and forming dense bushes.

\section{Everblooming Bedding Varieties}

The smaII, bright flowers are borne in great profusion from summer to autumn. Spring seedlings bloom in summer while summer seedlings make fine house plants for the winter.

Semperflorens Erfordi. Bright rosy carmine flowers with glossy green foliage. Ht. 10 in. Pkt. 25 cts.; 5 pkts. $\$ 1$. Semperflorens, Salmon Queen. Very attractive new variety with large, salmon-colored blossoms and dark foliage. Pkt. 25 cts.; 5 pkts. $\$ 1$.

Semperflorens, Vernon. A grand old favorite. often grown as a Christmas-flowering pot-plant and fine for bedding. It is of branching habit, with dark green foliage, shaded bronzy red and carmine-scarlet flowers. Pkt. 25 cts.; 5 pkts. $\$ 1$.

Gracilis luminosa. Fiery, dark scarlet flowers, and satiny brown foliage. Pkt. 25 cts.; 5 pkts. $\$ 1$.

Gracilis, Prima Donna. Large, handsome plants with shining green foliage, covered with bright rose-pink flowers. Pkt. 25 cts.; 5 pkts. $\$ 1$.

Gracilis, White Pearl. A fine companion to Prima Donna. The flowers are pure snowy white, and produced freely. Pkt. 25 cts.; 5 pkts. \$1.

\section{Tuberous-rooted Begonias}

For greenhouse and for summer bedding these are unequaled. Seedlings raised in heat early in spring will flower the same summer. They bloom very profusely.

Single Tuberous-rooted, Mixed. Saved from finest exhibition varieties, all having Iarge, well-formed flowers of many brilliant shades of color. Pkt. 50 cts.

Double Tuberous-rooted, Mixed. These produce, on strong, erect stems, an abundance of very double flowers, ranging from brilliant rose to carmine, often with white margin or mottling. They are very striking. Pkt. $50 \mathrm{cts}$.

\section{Brachycome - Swan River Daisy}

Iberidifolia, Mixed. One of the daintiest and most charming little annual flowers imaginable and easy to grow in any soil. The flowers are borne on graceful stems well above the delicate, finely Iaciniated foliage. They are ideal for low beds and borders, as the plants grow to a height of only 8 to 10 inches. Pkt. 15 cts.; $1 / 8$ oz. 50 cts.
Tuberous Begonias are gorgeous plants for dense shade. They need 2 to 3 inches of very rich soil and bountiful supplies of water at all times. The flowers are marvelous in color and size, and contrast wonderfully with the foliage.

\section{THIS WILL HELP YOU}

The Book of Annuals By A. C. Hottes. A helpful, illustrated guide to the handling of annual flowers and vines for seeding, transplanting, and pinching in. Gives the description, use, arrangement, and culture of each. 182 pp. Cloth, $\$ 1.50$.

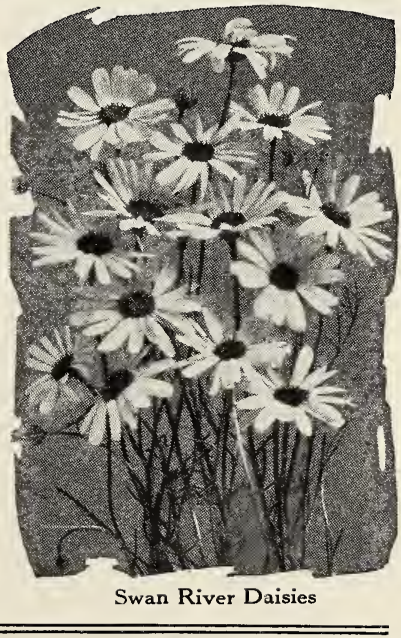




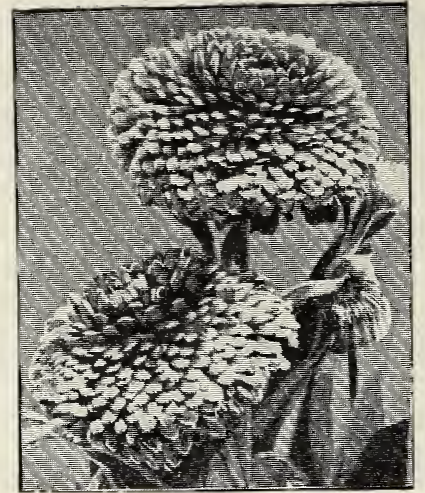

Calendula, The Ball

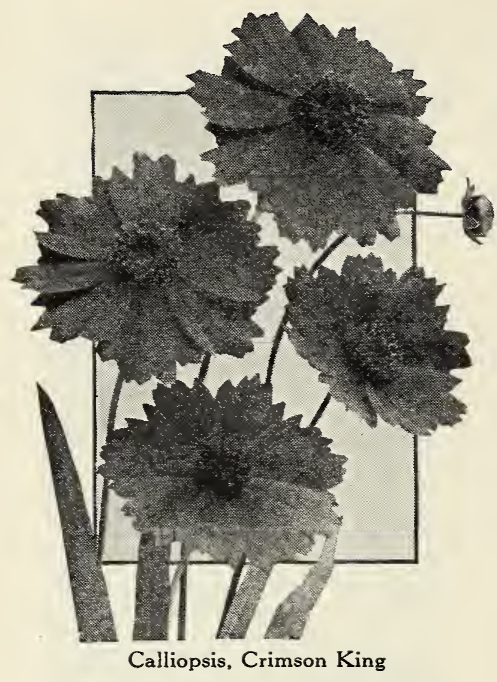

Few flowers are more easily grown than Calendulas, and really beautiful specimen blooms may be produced by the splendid new strains we are offering. For such specimens the plants should be liberally fed and disbudded. For garden display only the most ordinary care is needed to keep up a continual sheet of bloom through summer and fall.

To insure strong, healthy plants, it is well to dust the seeds lightly with Semesan before sowing.

\section{Calendula - Pot Marigold}

One of the best and showiest free-flowering hardy annuals, growing in any good garden soil, and producing a fine effect in beds or mixed borders. It is particularly bright in late fall, continuing in bloom from early summer until killed by frost. Valuable also for pot culture, blooming freely in winter and early spring. Sow the seed outdoors in April. Ht. $1 \mathrm{ft}$.

Ball's Gold. A new, bright yellow strain. It has the same fullness of flower as The Ball. Pkt. 25 cts.

The Ball. This special forcing strain produces large, extradouble flowers of bright orange. Pkt. 25 cts.; $1 / 40 z .75$ cts.

Campfire (Sensation). Enormous brilliant orange variety with a scarlet sheen and a fuII yellow center. Pkt. 35 cts.

Lemon Queen. This is of brightest sulphur-yellow. It is double and always very showy. Pkt. $10 \mathrm{cts}$; $1 / 2 \mathrm{oz} .50 \mathrm{cts}$.

Orange King. Fine for cutting, bearing wonderful double flowers of the deepest orange-red. Pkt. $10 \mathrm{cts}$.; $1 / 2 \mathrm{oz} .50 \mathrm{cts}$.

Double Mixed. AII colors. Pkt. $10 \mathrm{cts}$; $1 / 2 \mathrm{oz} .50 \mathrm{cts}$.

\section{Calliopsis}

This blooms from June until frost, grows 2 to 3 feet high, branches freely, and has long, wiry flower-stems crowned with lovely clusters of smaII, daisy-like flowers in beautiful shades of crimson, orange, and yellow. Sow in May and transplant 12 inches apart. For early flowers, sow seed in the hotbed in March. For other varieties, see Coreopsis in Perennial List. Bicolor nana. Dwarf, compact plants, fine for potting, with clear yellow flowers having small garnet eye. Ht. $10 \mathrm{in}$. Crimson King. Rich velvety crimson-garnet flowers. Ht. 10 in. Golden Wave. Fine, rich golden yellow, contrasting with the dark chestnut-brown center. Ht. $1 \mathrm{ft}$.

Mixed Colors. A select mixture of all of the above varieties. Each of the above, pkt. $10 \mathrm{cts}$.; $1 / 40 \mathrm{oz} .50 \mathrm{cts}$.

\section{Candytuft - Iberis}

The Candytufts are fine for edgings, bedding, massing, rockeries, or for cutting. Several of the varieties are fragrant, and aII are profuse in bloom. Sow outdoors in April, and thin weII when the plants are about an inch high. Sow again in a month, and late in July for fall flowers. Give rich soil and water freely. For Perennial varieties, see Perennial List.

Carmine. Large trusses of bright carmine-rose. Ht. $1 \mathrm{ft}$. Crimson. Rich deep shade of crimson. Ht. $1 \mathrm{ft}$.

Giant White Hyacinth-flowered or Improved Empress. Very fine Iarge white trusses of branching habit. An extra-choice, free-blooming strain, $11 / 2$ feet high and the best for cutting. Lilac. A particularly charming Iilac color. Ht. $1 \mathrm{ft}$.

Mixed. Including the colors mentioned above.

Each of the above, pkt. $10 \mathrm{cts}$.; 1/40z. $50 \mathrm{cts}$; oz. $\$ 1.50$

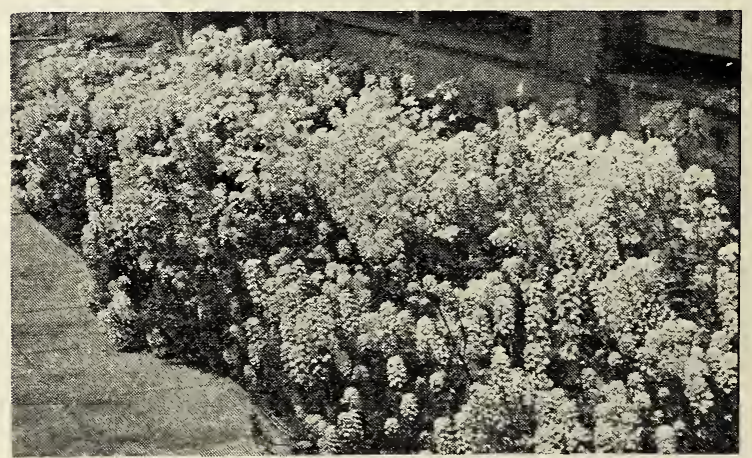

Giant White Hyacinth-flowered Candytuft 


\section{Carnation}

The Carnation has Iong been a prized favorite, for it is easily grown in flower-beds, borders, or pots. Plants from seed bloom more profusely than propagated plants. The pleasing fragrance and richness of colors make it indispensable, both for greenhouse culture in winter and for the garden in summer. For Dwarf Carnations, see Perennial List.

\section{Chabaud's Giant Outdoor Strain}

Many gardeners do not realize how readily these Carnations may be grown. Seed may be sown outside in April, when cold weather has gone or for early bloom, sow early in a frame, greenhouse, or sunny window. Plant out the seedlings 6 inches apart and from midsummer till frost you will have Carnations as full and sweetly perfumed as those sold by the florist and almost as large. AII they need is garden soil of average quality, and plenty of sun. To get best results, dig a little bone-meal into the bed when planting and rake some into the surface during growth. To get large blooms, allow only one bud to a stem and full flowering will come six weeks after planting. The plants are strong and robust, carrying their large flowers on long, stiff stems weIl suited for cutting. They usually come about 90 per cent double and true to color, but even the few singles and semi-doubles will charm you with their elegance of form and delightful clove fragrance.

Jeane Dionis. White.

Legion of Honor. Salmon.

Marie Chabaud. Yellow. Mixed.

Nero. Rich crimson.

Sparkler. Cardinal.

The Pearl. Rose-pink.

Each, pkt. 25 cts.; all 6 for $\$ 1.25 ; 1 / 80 z$. $\$ 1$

\section{Marguerite Carnations}

Very popular Carnations with the amateur, as they flower in July or August if sown in April. This strain is of extra-fine quality and has Iarge, double, beautifully fringed, highly scented flowers. If protected they survive an ordinary winter and bloom freely next spring. Ht. $11 / 2 \mathrm{ft}$. Pink, White, Scarlet, and Mixed. Each, pkt. 15 cts.; $1 / 4$ oz. 50 cts.

\section{Chinese Lantern Plant • Physalis}

Francheti. This forms dense bushes about 2 feet high, with bright orange-scarlet, lantern-like fruits. May be had in flower frrst year from seed if sown in April. The fruits are often displayed in florist shops and are very interesting, and of splendid decorative value. Pkt. 25 cts.; 5 pkts. \$1.

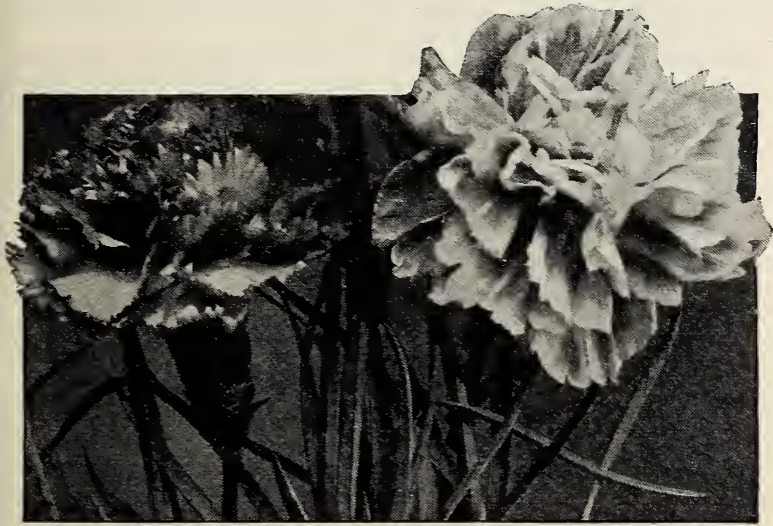

Marguerite Carnations

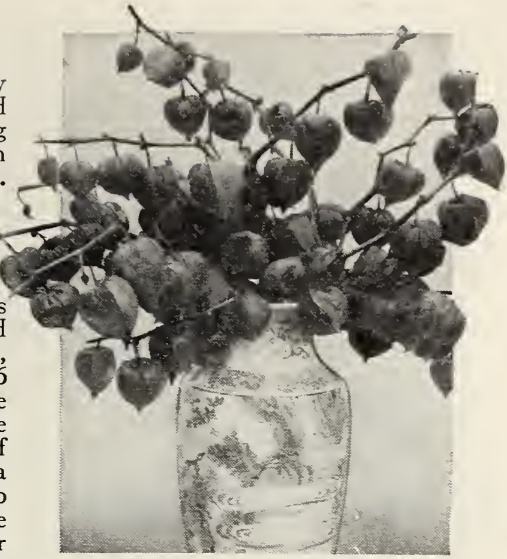

Chinese Lantern Plant

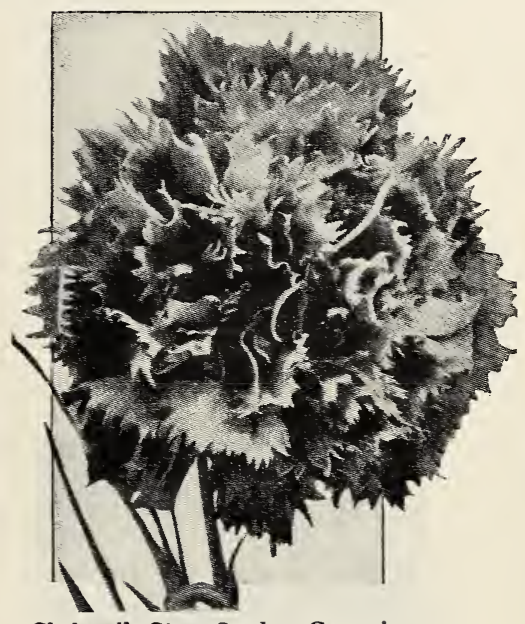

Chabaud's Giant Outdoor Carnation

There is something very fascinating about the Carnation or Pink family. There are dozens of different types, from the tiny rock plants to the Sweet Williams and the big florists' carnations. The Chinese Pinks, Diantbus cbinensis, are particularly easy to grow and look well mixed with either Chaubaud or Marguerite Carnations in vases. Always cut garden Carnations with the longest possible stems to insure strong new shoots from the bottom of the plants. 


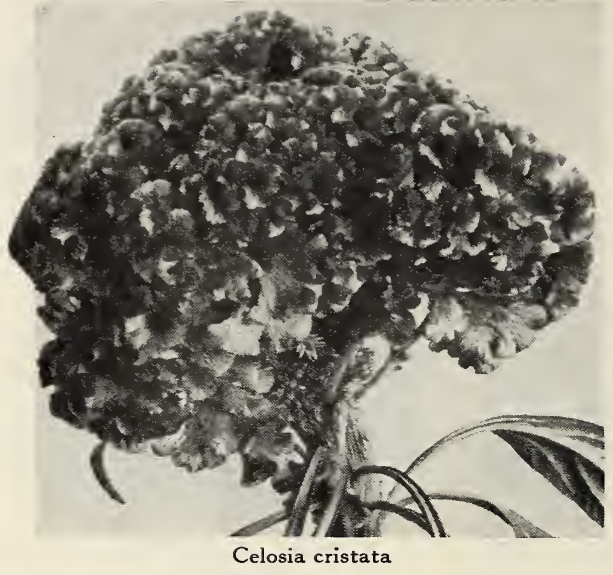

Celosia cristata

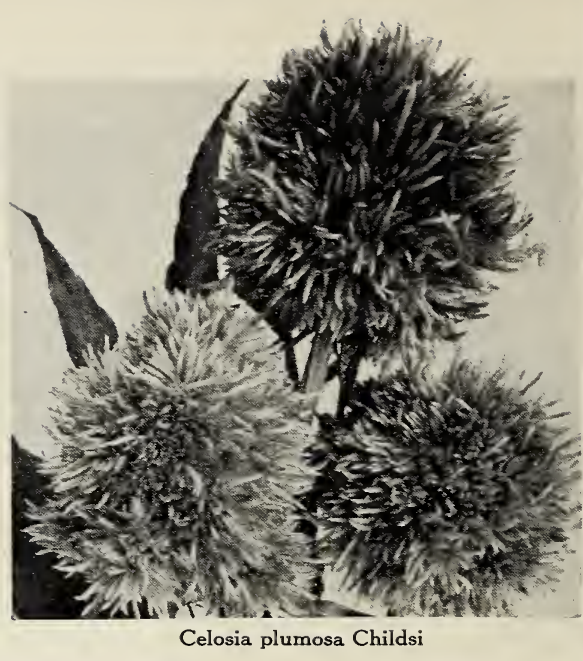

\section{Celosia}

Cockscombs are jolly, oldfashioned flowers which require only the most casual care. Even the new, giant feathery kinds, much more handsome than those our grandmothers grew, need only a bit of fair ground open to the sun and they will make a gorgeous display throughout the entire season.

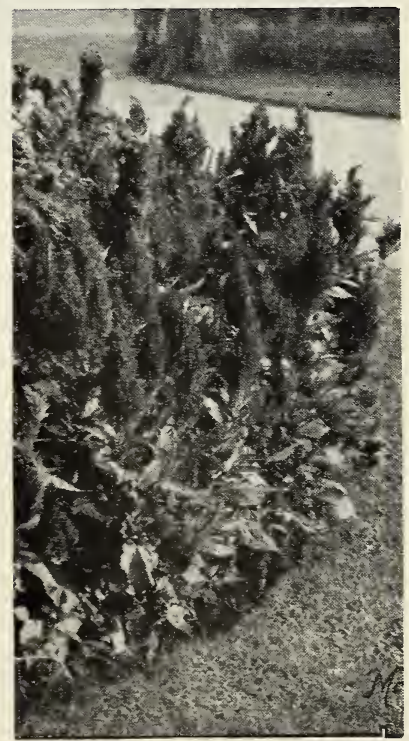

Celosia plumosa
Dwarf Cockscombs are showy in the border, while the feathered or plumed varieties are especially attractive in Iarge beds, and are useful for cutting. The flowers retain their color, even when dry, and can be used in winter bouquets.

\section{Celosia cristata - Cockscomb}

A free bloomer growing best in rather light, not too rich soil, and makes frne border and pot plants. Sow seed indoors in early spring and plant out in May, or sow outdoors in May.

Dwarf, Mixed. Easily grown and should be planted in every garden. These dwarf-growing varieties are fine for borders and bloom all summer. Ht. $1 \mathrm{ft}$. Pkt. $10 \mathrm{cts.;} 1 / 4 \mathrm{oz} .75 \mathrm{cts}$. Empress. Enormous crimson heads resembling a cockscomb.

Dark bronze foliage. Ht. 10 in. Pkt. 15 cts.; $1 / 4$ oz. $\$ 1$.

\section{Celosia plumosa - Feathered Cockscomb}

There are no more showy summer and fall bedding plants than the Plumed Celosias. Planted in masses, the color effect is magnificent. The handsome plants are symmetrical, every branch bearing a pointed plume of rich color. $\mathrm{Ht}$. $2 \mathrm{ft}$.

Chrysantheflora, Mixed. Huge chrysanthemum-like flowersold rose, salmon, golden yellow, wisteria, violet, mulberry, Nile-green, lemon, maroon, and orange-can be dried like Everlastings. Pkt. 25 cts.; 5 pkts. \$1.

Ostrich Plumed. Of pyramidal growth with superb, pointed plumes, making grand pot-plants and gorgeous beds, blooming from July to September. It prefers a fairly rich soil. Ht. $2 \mathrm{ft}$. Crimson, Orange, and Mixed. Each, pkt. 10 cts.; $1 / 40 z .75$ cts.

Pride of Castle Gould. The pyramidal, compact growth, 2 to 3 feet high, supports feathered racemes of blood-red, carmine, orange-yellow, salmon, scarlet, dark orange, and wine-red. This is the best of the feathered Celosias. Pkt. 25 cts.; $1 / 8$ oz. \$1.

Thompsoni magnifica. Colors range from the clearest yellow to the darkest blood-red. Fine, full plumes. Ht. $3 \mathrm{ft}$. Pkt. 10 cts.; $1 / 4$ oz. 40 cts.; oz. \$1.25.

\section{Celosia plumosa Childsi - Chinese Woolflower}

This most unusual type of Feathered Celosia grows 2 to 3 feet high. There are many branches issuing from the main stalk, each stem having the silky tendrils common to Celosia. The tips have a brushy appearance. Crimson, Scarlet, Pink, Yellow, and Mixed. Each, pkt. 15 cts.; 1/40z. \$1. 


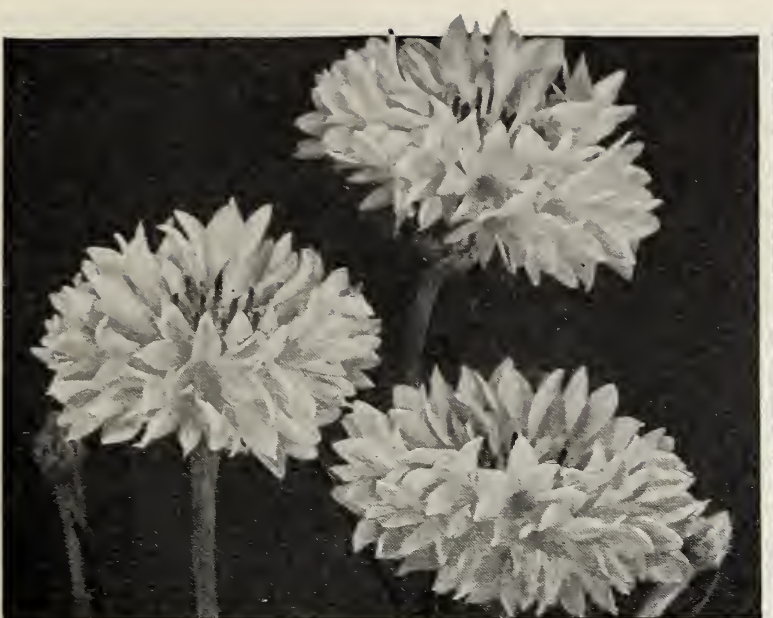

Double Cornflower

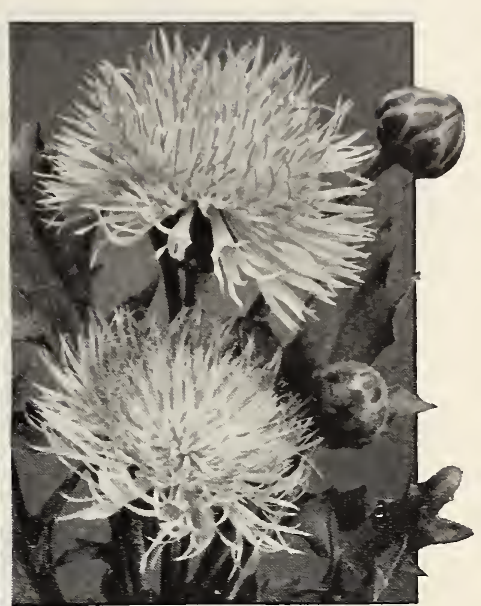

Giant Sweet Sultan

\section{Centaurea}

This popular annual includes such oId-fashioned favorites as the Bachelor's Buttons or Cornflowers, and Sweet Sultans. They are easy to grow, take care of themseIves, blcom continuously, and even come up again the next year from the seed that has dropped in the ground. Sow outdoors in April. Thin plants to stand 10 inches apart. Ht. 2 to $3 \mathrm{ft}$.

\section{Cornflower (Centaurea cyanus)}

Also known as Bachelor's Button, Bluet, and Ragged Sailor. Extremely showy in the garden and fine for cutting.

Double Blue Emperor. An improved strain of the original old-fashioned Cornflower. The flowers are much larger, very fuII, and of a more intense blue. Pkt. 15 cts.; 1/40z. 50 cts. Double Rose. Full double flowers. Pkt. 15 cts.; $1 / 40 z .50$ cts.

Double Mixed. Pkt. 15 cts.; $1 / 4$ oz. 50 cts.; oz. $\$ 1.50$.

Single Blue Emperor. Pkt. $10 \mathrm{cts}$.; $1 / 4 \mathrm{oz} .35 \mathrm{cts} ., \mathrm{oz} . \$ 1$.

Single Mixed. Pkt. 10 cts.; 1/4oz. 35 cts.; oz. \$1.

\section{Giant Sweet Sultans (Centaurea imperialis)}

These are wonderful flowers for cutting-long-stemmed, exquisitely fringed, most graceful in appearance, and delightfully fragrant. The most beautiful colors are found among them. For fine flowers make successive sowings two weeks apart during May and June. They do well in a rich, loose soil thorcughly prepared. Cover seeds $1 / 4$ inch. Ht. 2 to $3 \mathrm{ft}$.

Imperialis. Amaranth Red, Rose, White, Lavender, Lilac, Purple, or Mixed Colors. Each, pkt. 15 cts.; $1 / 40 z .50$ cts.

\section{Various Centaureas}

Americana. The thistle-like flowers, often 4 inches across, are deep lavender. Plants should be placed at least 1 foot apart. Ht. 3 ft. Pkt. 15 cts.; $1 / 4 \mathrm{oz} .50$ cts.

Suaveolens (Yellow Sweet SuItan). Very showy, Iarge, bright yellow, sweet-scented flowers used extensively by the florist as a cut-flower. Pkt. $15 \mathrm{cts} . ; 1 / 4 \mathrm{oz} .50 \mathrm{cts}$.

\section{White-leaved Centaurea • Dusty Millers}

These are largely used for edging of beds or borders of the flower-garden. The glistening white foliage, with bright coleus, salvia, or red canna, is very striking. Ht. 1 to $11 / 2 \mathrm{ft}$.

Candidissima. Rapid-growing annual grown only for its Ianced silver-coated foliage. Pkt. 15 cts.; $1 / 4$ oz. 75 cts.

Gymnocarpa. Silver fern-like leaves. Pkt. 15 cts.; 1/4 oz. 50 cts.
AII Centaureas are good garden plants. Americana is one of the most showy and splendid, especially if a few white ones appear among the lavender, which sometimes happens. Suaveolens should be planted with the Sweet Sultans. It is exactly like them and supplies a color they lack. Everybody knows and likes the Cornflower, especially the new double blue variety.

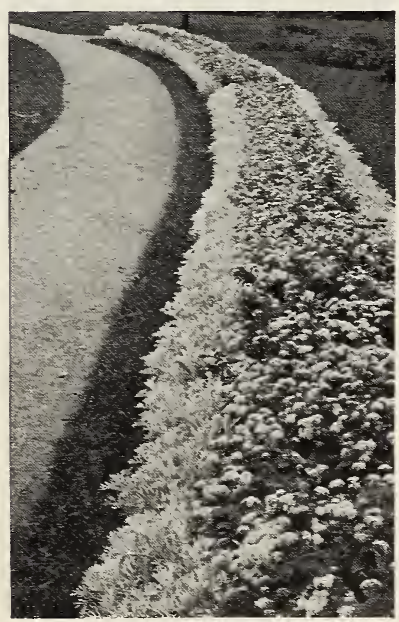

White-leaved Centaurea 


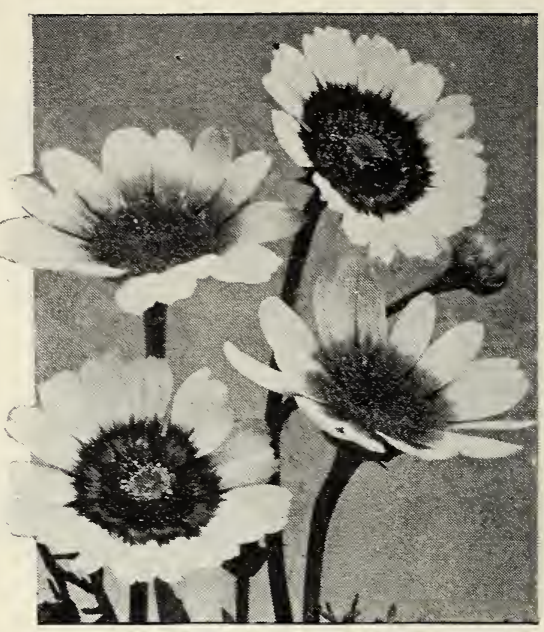

Single Annual Chrysanthemums, Tricolor

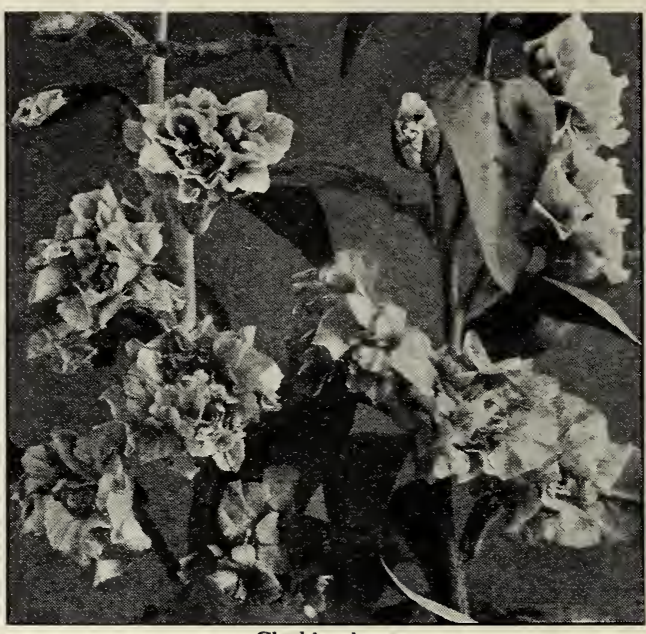

Clarkia elegans

\section{Chrysanthemums}

There are two very splendid, seIdom-seen annuals on this page. Clarkia makes one of the finest cut-flowers we. know, and the curious Giant Spider Flower or Cleome is superb when established in open places in the shrubbery or perennial border where it may reseed itself.

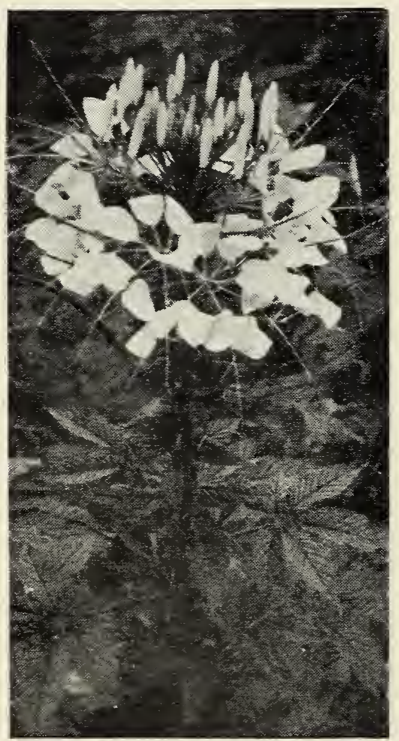

Cleome pungens
These bloom profusely from early summer until frost, and make a splendid show in large beds. Sow seeds early indoors and transplant; or sow Iater where the plants are to flower, and thin seedlings to 10 inches apart. Pinching back in early growth makes plants bushy. For Hardy and FaII Flowering varieties, see Perennial List.

\section{Single Varieties}

The plants average 2 feet in height, and bear their daisylike flowers in great profusion on strong stems.

Morning Star. Petals canary-yellow, with halo of deeper yelIow; disc dark yellow. Pkt. 15 cts.

Tricolor, Mixed. Daisy-like blooms with two zones of deeper colors surrounding center disc. Pkt. 15 cts.

\section{Double Varieties}

These do not resemble the very double florists' Chrysanthemums but are full-petaled, with large open center.

Coronarium. Full-centered with many petals. Ht. 15 in. Double White, Yellow, or Mixed Colors. Pkt. 15 cts.

\section{Clarkia}

This pretty annual, of easy cultivation, succeeds well in any garden soil, either in sun or shade, growing $21 / 2$ feet high, with sprays of double flowers. They are especially attractive in masses, and fine for outdoors. Sow indoors in April.

Elegans, Double. These flowers resemble long sprays of cherry-blossoms and are welcomed as cut-flowers. If cut before fully developed, they last unusually weII.

Carmine Queen Purple Queen Scarlet Queen

Chamois Queen Salmon Queen White Queen Vesuvius. Double flowers of orange-scarlet. Mixed. Each, pkt. $15 \mathrm{cts}$.; $1 / 40 \mathrm{oz} .50 \mathrm{cts}$.

\section{Cleome - Giant Spider Flower}

Pungens, Rose Queen. A quick-growing annual with light, curious flowerheads of a bright rose color. The individual flowers hang gracefully on slender, thread-like stems resembling spiders' legs. Sow seed outdoors in April, thin to stand 2 feet apart. Ht. $4 \mathrm{ft}$. Pkt. $10 \mathrm{cts}$; $1 / 4 \mathrm{oz}$. $50 \mathrm{cts}$. 


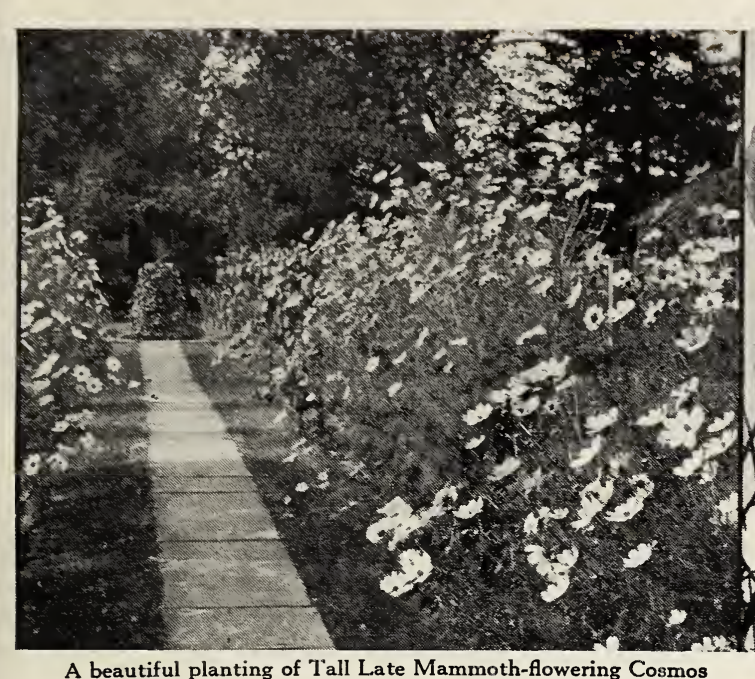

\section{Cosmos}

A hardy and rapid-growing annual, forming bush-like plants 4 to 7 feet high, with feathery green ornamental foliage, covered with large flowers somewhat resembling the single dahlia. For ordinary culture, sow outdoors in April in rather light soil, not too rich, and preferably in a sunny situation. Cover the seed with from $1 / 4$ to $1 / 2$ inch of fine soil firmly pressed down. If planted in rows, make the rows about 2 feet apart, and thin to stand about 1 foot apart in the row. If more bushy growth is desired, pinch off the tops of the plants when 1 foot high.

\section{Dwarf Early Summer-flowering}

This early-flowering strain grows about 4 feet high, and blooms profusely four weeks earlier than the large sorts. The flowers are not as large as the Late Mammoth-flowering. White, Pink, Crimson, or Mixed. Each, pkt. 15 cts.

\section{Tall Late Mammoth-flowering}

These taII, graceful plants are most effective when planted in broad masses along background borders against evergreens or shrubs. The gigantic flowers, borne on long stems, and the feathery foliage lend themselves to graceful arrangements for bouquets. Blooms from late August until frost. Ht. 5 to $7 \mathrm{ft}$. White, Pink, Crimson, or Mixed. Each, pkt. 15 cts.; $1 / 4 \mathrm{oz}$. 35 cts.

\section{Early Double-flowering}

This type of Cosmos has real double flowers about $11 / 2$ inches in diameter, resembling an anemone-flowered chrysanthemum. The plants grow to a height of about 4 feet, forming a perfect bush, massed with bloom. They come about 65 per cent double from seed and bloom in 70 days from the day seed is sown. Seed sown in Iate April will be in bloom by JuIy 4, and continue until frost. White SnowbalI, Eureka Pink, Eureka Crimson, or Mixed. Each, pkt. 25 cts.; $1 / 80 z .75$ cts.

\section{Late Double-crested Flowering}

Particularly effective flowers for cutting. About 65 per cent of the seedlings bear beautifully formed flowers with fulldouble centers and an outer row of guard petals resembling the anemone-flowered chrvsanthemum. They bloom from early August until frost. Ht. $5 \mathrm{ft}$. Crimson King, Pink Beauty, White Queen, or Mixed. Each, pkt. 20 cts.; $1 / 8$ oz. 60 cts.

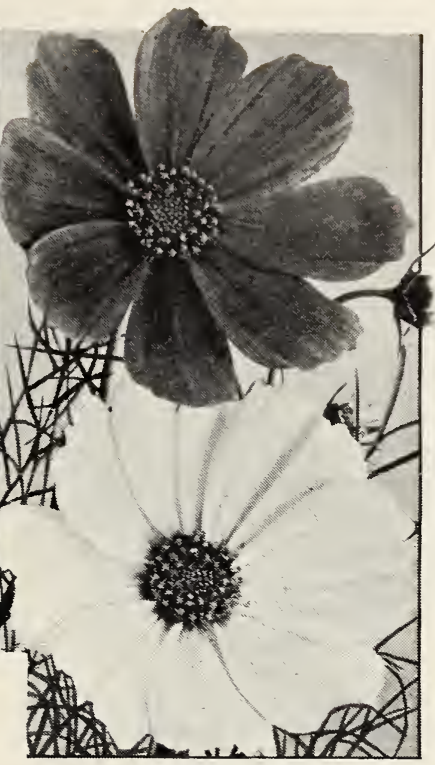

Single Cosmos

While the early types are pretty, the real aristocrats of the Cosmos family are the gigantic, late-blooming varieties which sometimes run a race with the frrst frosts.

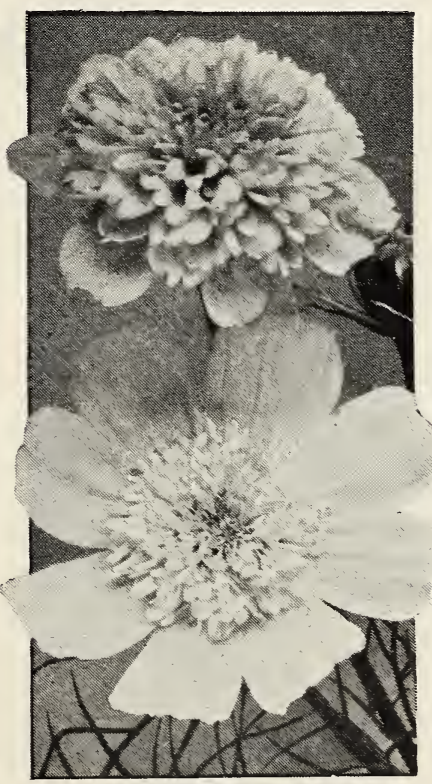

Double Cosmos 


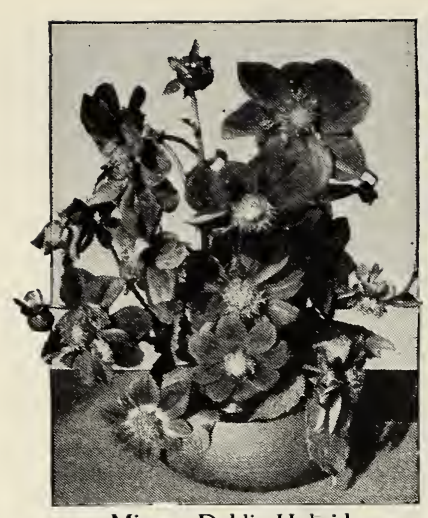

Mignon Dahlia Hybrids

The Chinese Forget-menot is very effective when interplanted with the tall or half-dwarf Snapdragons of pale pink, apricot, or light yellow shades. Its graceful blue sprays provide just the right degree of lightness to set off the heavier blooms of the Snaps, either in the garden or in vases. It works well with gladiolus and other flowers, too.

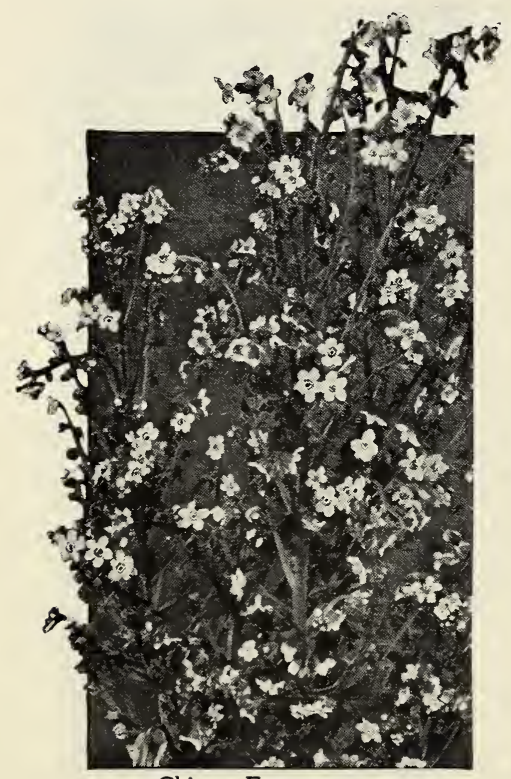

Chinese Forget-me-not

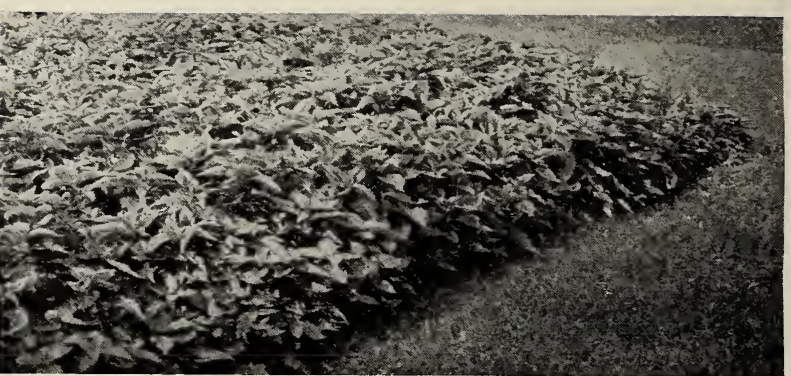

Bed of Mammoth Rainbow Coleus

\section{Coleus - Flame Nettle}

The finest colored, most attractive annual foliage plants for house or garden. Sow indoors in March. When 8 inches high, pinch out center to make plants bushy. Ht. 1 to $11 / 2 \mathrm{ft}$.

Mammoth Rainbow Mixture. The leaves often measure 10 inches in length and 8 inches in width, heart-shaped and handsomely crimped, toothed and frilled. Their color combinations are remarkably rich. The plants bear pretty racemes of blue flowers. Pkt. 25 cts.

Fine Mixed. Not as large-leaved as the above. Pkt. 15 cts.

\section{Cynoglossum - Chinese Forget-me-not}

Amabile. An annual of the easiest culture, forming strong, bushy plants $11 / 2$ feet high and producing sprays of intense blue forget-me-not-like flowers throughout the summer. Unsurpassed for massed blue bouquets. Highly desirable, as blue flowers of this shade are scarce. Sow outdoors in May. Blue or White. Each, pkt. 25 cts.; 1/40z. $\$ 1$.

\section{Dahlia}

But few people know Dahlias can be raised from seed and will bloom the first year. The seeds germinate easily and from the very first are strong and sturdy little plants. Plant them in a shallow box or pan early in March or April, transplant them carefully as their growth demands, and keep the soil moderately moist. When all danger from frost is over, plant them in the bed or border in the garden, and from then on they will prove no more trouble than if the tubers had been used instead of seed. Ht. 3 to $5 \mathrm{ft}$.

Cactus Dahlia Varieties, Mixed. Pkt. 35 cts.; 1/4oz. \$1.25. Giant Single Perfection Mixed. Of strong, robust habit, flowers of immense size, in a bewildering variety of color. These are very interesting to grow. Pkt. 25 cts.; 1/4oz. $\$ 1$.

Giant Double-flowering Select Mixed. A selection of varieties having unusual grace and comprising the best types and colorings. Pkt. 50 cts.; $1 / 4 \mathrm{oz}$. $\$ 2$.

Mignon Hybrids. In less than three months from seed the dwarf, compact plants will hold a wealth of bloom which will continue until frost. The flowers, resembling the weIlknown single Dahlias, are held erect on long, stiff stems well above the foliage. They are admirable for cut-flowers and come in deep crimson, delicate pinks and rose, mauves, various shades of scarlet and purple, in yellow and in white. The plants, 2 feet high, are suited to bedding. Pkt. 50 cts.

Select Exhibition Dahlia Seed. This seed has been selected with the greatest care by an eminent Dahlia originator from parent plants which produced such fine varieties as Jersey Beauty, Elite Glory, Elite Peach, Jersey Beacon, Eagle Rock Beauty, Eagle Rock Gem, Jersey Masterpiece, Violet Wonder, Sanhican Nymph, and Trentonian. From this seed, you may get a true plant of any of these or beautiful variations. Pkt. $\$ 1$. 


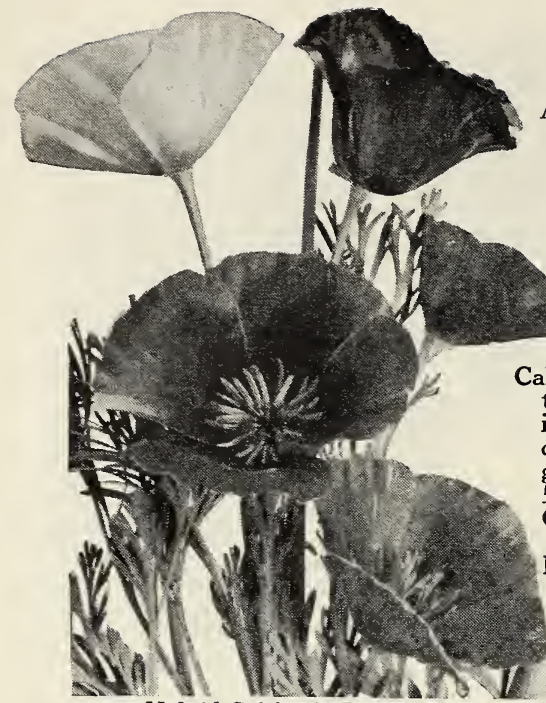

Hybrid California Poppy

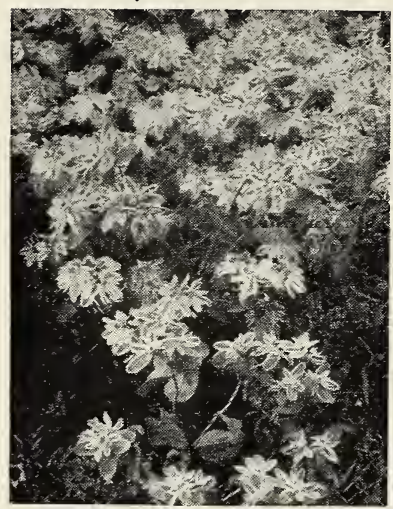

Snow-on-the-Mountain

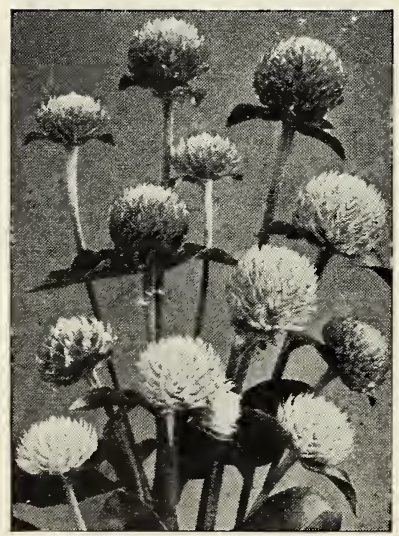

Globe Amaranth

\section{Eschscholtzia - California Poppy}

A very interesting and popular annual, readily grown from seed sown outdoors in March or September in the spot where they are wanted and simply thinned out. The beautiful lace-like foliage covers the entire growth a foot high and has a silvery sheen. The cone-shaped poppy flowers appear on fairly long stems from June until frost without interruption. If the flowers are cut early in the morning while they are closed-up buds, they will last fully two days in water.

Californica (California Poppy). Single orange flowers. Pkt. 10 cts.; $1 / 4$ oz. 35 cts.

California Hybrids Mixed. The improvement represented in this new strain will be a revelation. The single flowers come in lovely new shades, including soft pink, scarlet, chrome, copper-red, claret, and royal purple, which bring to the garden the color of the western canyons. Pkt. 25 cts.; 5 pkts. $\$ 1$.

Carmine King. Beautiful single flowers in carmine-rose. Pkt. 10 cts.; $1 / 4$ oz. 35 cts.

Double Rose. This is an unusually good strain of a light rose California Poppy, quite true to color, with large, fluffy very double flowers. It will make a bright colorspot in your garden. Pkt. 25 cts.; 5 pkts. $\$ 1$.

Golden West. Bright yellow, single flowers with dark orange at the base of the petals. Pkt. 10 cts.; $1 / 4$ oz. 35 cts.

Pure White. Large, single flowers; sage-green foliage. Pkt. 10 cts.; $1 / 4$ oz. 35 cts.

Fine Mixed. Single flowers in a wide range of colors. Pkt. 10 cts.; $1 / 4$ oz. 35 cts.

\section{Euphorbia}

Strong-growing annuals, suitable for beds of tall-growing plants or mixed borders. The foliage is exceedingly ornamental. Sow outdoors in April.

Variegata (Snow-on-the-Mountain). Elegant, bushy plants, with broad green leaves, veined and margined with white. Attractive in foliage groups. Ht. $2 \mathrm{ft}$. Pkt. $10 \mathrm{cts}$; $1 / 4 \mathrm{oz}$. 35 cts.

Heterophylla (Annual Poinsettia; Mexican Fire-Plant). An annual, bushy plant, with highly ornamental leaves, which in summer and autumn become dark fiery scarlet. Ht. 2 to $3 \mathrm{ft}$. Pkt. 15 cts。; $1 / 4$ oz. 50 cts.

\section{Everlasting Flowers}

These were great favorites with our grandparents and are today as popular as ever. The Straw Flower (Helichrysum) is perhaps better known than the other sorts listed, but all are fully as interesting for giving variety to dried winter bouquets. These make fine gifts from your own garden to your friends. The drying is a simple operation: cut before fully expanded, bunch like sweet peas, and hang on a line upside down in a cool, dark, dry room. It takes ten days. Sow seed indoors in March; outdoors in May, in a sunny spot.

Acroclinium, Mixed. Pretty white and rose, daisy-like flowers, so desirable for winter bouquets. Ht. $1 \mathrm{ft}$.

Globe Amaranth, Mixed (Gomphrena). Flowers of white, pink, rose, and purple, like heads of clover, but are Straw Flowers. Ht. $1 \mathrm{ft}$. We also offer this in two separate colors, Orange and Red.

Helichrysum monstrosum, Mixed (Straw Flower). Ht. $2 \mathrm{ft}$. For separate colors see Alphabetical List.

Rhodanthe, Mixed Colors. Neat, slender plants with silvery leaves and dainty Iavender, pink, and white flowers like inverted cones. Ht. $1 \mathrm{ft}$.

Xeranthemum annuum, Mixed. Showy rose, purple, and white daisy-like flowers with an outer corolla and a cup in the center.

Each of the above, pkt. $10 \mathrm{cts}$; 1/40z. $50 \mathrm{cts}$.

COLLECTION: 25 kinds of Everlasting Flowers for $\$ 1.25$ 


\section{Four o'Clock - Marvel of Peru}

This is another good old-fashioned annual flower of bushy habit, bearing hundreds of white, yellow, crimson, and violet flowers during the season. Very charming when used as a hedge plant, with its glossy foliage very closely set and dotted all over with flowers in the afternoon. Ht. $2 \mathrm{ft}$. Sow seed outdoors in April in a bright, sunny location.

Fine Mixed. Pkt. 10 cts.; 1/2oz. 30 cts.

\section{Gaillardia - Blanket Flower}

A splendid garden border plant and excellent for cutting. The Iarge, highly colored, da sy-like flowers appear uninterruptedly the entire season on stout erect stems often 15 to 18 inches in length. The seed may be sown in the garden as soon as the ground is fit to work in April, and the plants thinned out to stand about a foot apart. For hardy varieties see Perennial List.

Lorenziana, Double Mixed. Very attractive double flowers o unusual ball form, in a great variety of bright colors, borne from midsummer to frost. Fine for bedding and one of the best for cutting. Ht. $1 \mathrm{ft}$. Pkt. $10 \mathrm{cts}$; $1 / 1 \mathrm{oz}$. $35 \mathrm{cts}$.

Salmonea. Large, single, salmon-red flowers with deep crimson centers; very showy and nice for cutting. Ht. $2 \mathrm{ft}$. Pkt. 15 cts.; $1 / 4$ oz. 50 cts.

\section{Globe Amaranth. See Everlasting Flowers}

\section{Godetia - Satin Flower}

Azalea-flowered, Mixed. Resembles the Azalea both in form and color. The plants grow 1 foot high and bloom in great profusion for six weeks. Excellent for massing and cutting. They do best in a rather poor soil. Sow outdoors in April in partial shade. Pkt. 25 cts.; 5 pkts. $\$ 1$.

Carminea. This is a very desirable color for cutting-a clear carmine-pink with a very striking marking, and will make the Azalea-flowered Godetia more popular. This strain is more double in type and more Azalea-like.

Tall. This type grows about $2 \frac{1}{2}$ to 3 feet high. Pkt. 25 cts.; 5 pkts. $\$ 1$.

Dwarf. Of lower habit, growing 18 to 20 inches high. Pkt. 25 cts.; 5 pkts. $\$ 1$.

\section{Ornamental Grasses}

Specimen plants, or entire beds of harmonious varieties are interesting. They do best near water, being valuable for cutting and may be preserved for winter bouquets.

COLLECTION: 12 named varieties, 50 cts.

\section{Gypsophila • Baby's Breath}

Feathery panicles of tiny star-shaped flowers, gracefully and daintily borne on slender stems. A charming effect may be had by mixing sprays of Baby's Breath with other longstemmed cut-flowers. Sow seed outdoors in April. See Perennial List for hardy varieties.

Elegans, Crimson Gem. Those who know the beauty of the White Baby's Breath in bouquet arrangements will appreciate this new strain. It has a charming, bright rosycrimson color and contrasts beautifully in bouquets of large white or blue flowers. Pkt. 35 cts.

Elegans alba grandiflora, Covent Garden Market Strain. Larger-flowering, pure white form, of free, easy growth. Several sowings should be made during the season to keep up a supply. Pkt. 10 cts.; 1/2oz. 35 cts.

Elegans rosea. A pretty blush-pink form of the above and equally as valuable for cutting. Pkt. 10 cts.; $1 / 20 z .35$ cts.

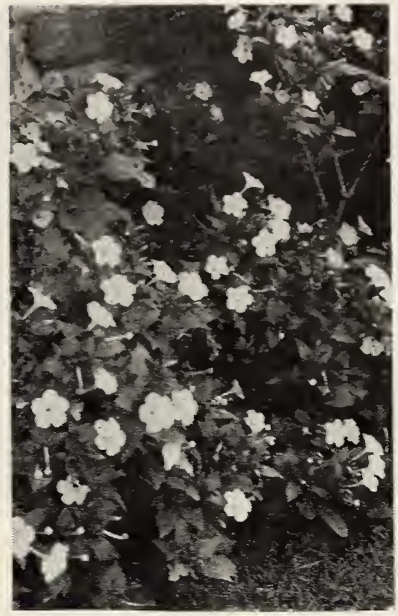

Four o'Clock
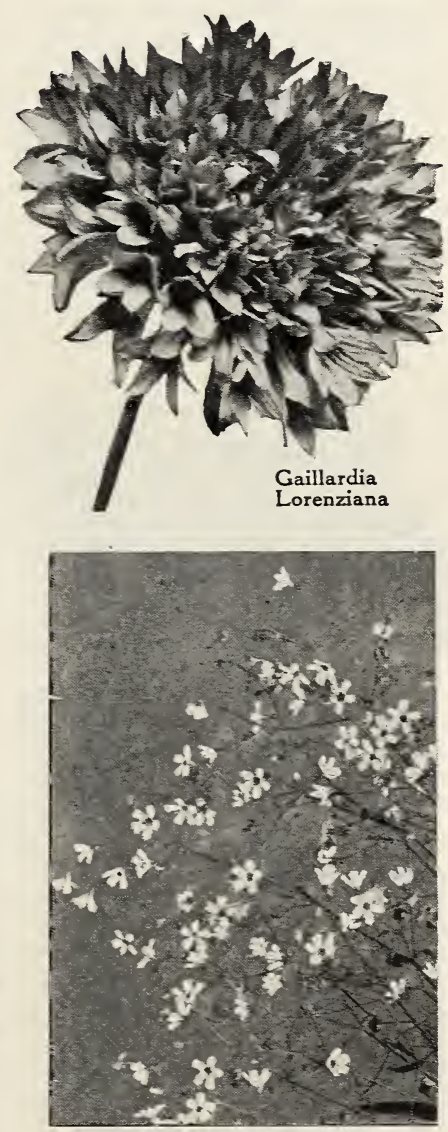

Gypsophila alba grandiflora 


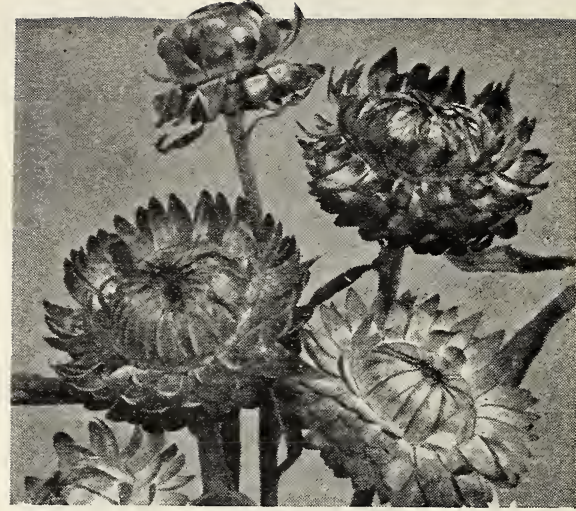

Helichrysum

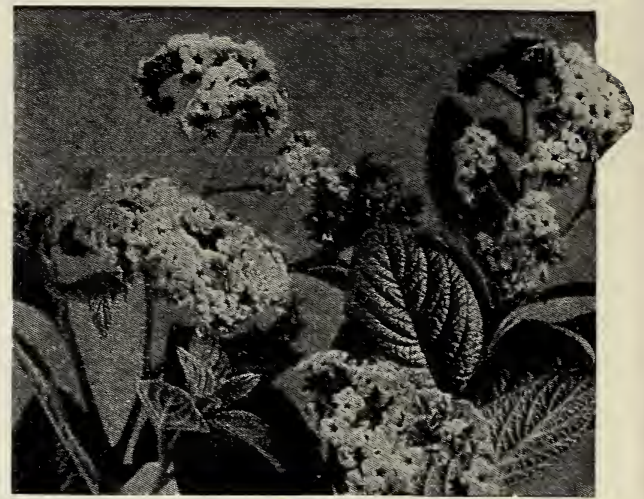

Regale Heliotrope
For winter bouquets, Straw Flowers should be cut before the centers open, and be hung upside down in a cool, dark place to dry. The foliage should be stripped off, and if it is desired, a fairly stiff wire may be twined about each stem to make them easier to handle in arranging them in bouquets.

To grow unusually Iarge flowers, disbud as you would with dahlias, allowing only one bud to remain on each stem.

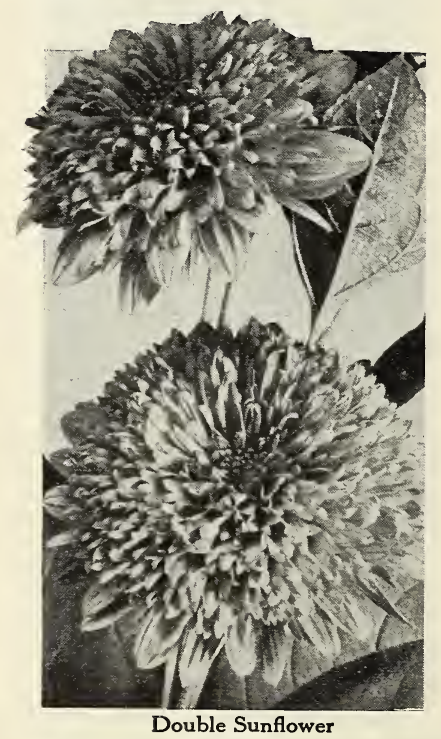

\section{Helianthus - Sunflower}

Prized for cutting, the tall sorts are Iargely used in the perennial border; the dwarf sorts make good edgings for the tall. Remarkable for the stately growth, size, and brilliancy of their flowers, making a very good effect among shrubbery and for screens. Sown on a sunny spot in April or May, they bloom from early summer until cut down by frost.

Cucumerifolius, Orion. A miniature Sunflower with golden yellow flowers having dark centers. The petals are twisted like a cactus dahlia. Pkt. $10 \mathrm{cts} . ; 1 / 4 \mathrm{oz} .35$ cts.

Double Chrysanthemum-flowered. Rich golden yellow, very double flowers. Ht. $7 \mathrm{ft}$. Pkt. $10 \mathrm{cts}$; $1 / 1 / 4 \mathrm{oz} .35 \mathrm{cts}$.

Red. Produces numerous well-shaped, dark-centered, brilliant flowers, banded with chestnut-red, merging to yellow at the petal tips. Ht. 3 to $4 \mathrm{ft}$. Pkt. $10 \mathrm{cts}$; $1 / 4 \mathrm{oz}$. 35 cts.

Large Single Russian. The old-fashioned Sunflower. Ht. 5 to $8 \mathrm{ft}$. Pkt. 5 cts.; oz. 10 cts.; $1 / 4$ lb. 25 cts.; lb. 75 cts.

\section{Helichrysum - Straw Flower}

One of the best of the "Everlastings." They succeed in any good garden soil. The large, double flowers of rich, glittering colors make a fine display in beds or borders, but are especially grown to dry for winter use in baskets and vases. Helichrysum should be planted in May, about 12 to 15 inches apart, giving room to develop. Salmon-Pink, Fireball, red; GoIden Ball, yellow; Violet Queen, Rose Queen, Silver Ball, white. Each, pkt. 15 cts.; $1 / 40 z$. 50 cts.; oz. $\$ 1.50$.

COLLECTION: One pkt. each of above 6 colors, $75 \mathrm{cts}$.

\section{See Everlasting Flowers for other varieties \\ Heliotrope}

A half-hardy plant, flowering during the whole season. Its delightfuI perfume makes it a most desirable bouquet flower. Useful for bedding and for pots and window-boxes. It prefers a cool, moist atmosphere and a rich soil. The seeds may be sown in pots in early spring and transplanted to the open in late May. Plants that are pruned back in Iate summer may be potted up in the fall for winter blooming indoors. Ht. $2 \mathrm{ft}$. Regale. A dwarf giant-flowered sort with large masses of bloom. Pkt. 35 cts.; 3 pkts. $\$ 1$.

The Book of Annuals. By Professor A. C. Hottes. HelpfuI, illustrated guide to the handling of annual flowers and vines. Gives the description, arrangement, use, and culture of each. $182 \mathrm{pp}$. cloth, $\$ 1.50$. 


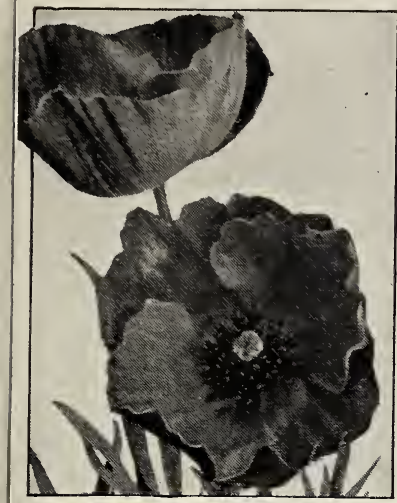

Yellow Tulip Poppies

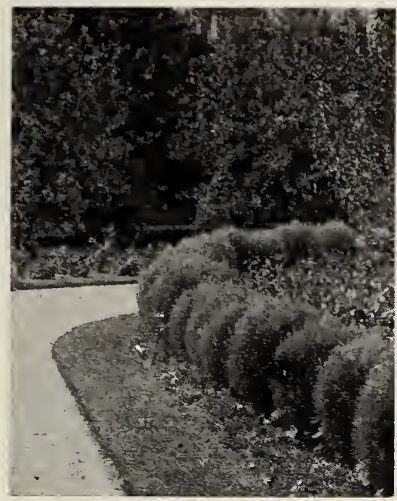

Kochia (Summer Cypress)

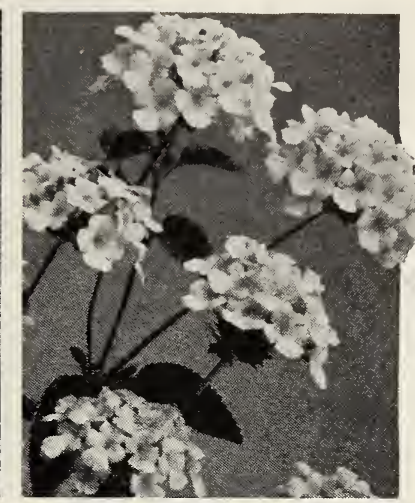

Lantana Blooms

\section{Everblooming Hollyhocks}

A new strain which flowers the first year from seed. In every way the same as the hardy varieties with the additional advantage of a long blooming period. Seed sown under glass in March will produce flowers in July and continue until frost. The same range of colors as in the perennial varieties. Ht. $5 \mathrm{ft}$. For hardy varieties see Perennial List.

Single Annual, Mixed Colors. Pkt. 15 cts.; $1 / 4$ oz. 75 cts. Double Annual, Mixed Colors. Pkt. 15 cts.; $1 / 4$ oz. 75 cts.

\section{Hunnemannia • Yellow Tulip Poppy}

Fumariæfolia. This very beautifuI plant forms a shrubby bush with finely cut, glaucous foliage like the California poppy, and produces large, tulip-shaped flowers on long, stiff stems, from August to November. In color they are a clear, brilliant yellow, the petals resembling crushed satin. The flowers will keep in water for several days. Sow seed early in May, in shallow drills where the plants are to bloom. Ht. 2 ft. Pkt. 10 cts.; $1 / 4$ oz. 50 cts.

\section{Impatiens}

Useful house-plant, with bright waxy flowers continually.

Holsti. Excellent for half-shaded location. Bears handsome, brilliant, cinnabar-red, waxy blooms all season. The flower is $11 / 2$ inches in diameter and is a native of East Africa. Used as a house-plant, it blooms continuously. Pkt. $25 \mathrm{cts}$.

Sultani Hybrids. A strong grower, $11 / 2$ to 2 feet tall, bearing continuously brilliant, rosy scarlet blossoms $11 / 2$ inches across, which contrast with the bright green foliage. A rare house-plant. Sow outdoors in ApriI. Pkt. 25 cts.

\section{Kochia}

Trichophylla (Summer Cypress). A pretty half-hardy foliage plant, 2 to 3 feet high, which grows into an oval, cypress-
like bush, with small, feathery, light green foliage, deepening as the season advances until it becomes a lovely crimson hue about September. Excellent for edging or hedging. Sow outdoors in May. Pkt. 10 cts.; 1/4 oz. 25 cts.

\section{Lantana}

Half-hardy greenhouse or bedding plants, constantly in bloom, bearing miniature, verbena-like heads of orange, white, and rose. Start seed indoors early.

Dwarf Bedding Hybrids. Excellent for bedding and pot culture. Will bloom freely all summer. Pkt. 15 cts.; $1 / 40 z$. 60 cts.

AII annual flowers should be grown quickly. Do not set out plants raised indoors until the weather is settled and do not sow seeds outside until you are sure they will not be checked by cold after they are up. Abundant water and rich soil are essential to the best development of almost aII of them. The flowers should be kept cut. If they areallowed to makeseed, they will stop blooming.

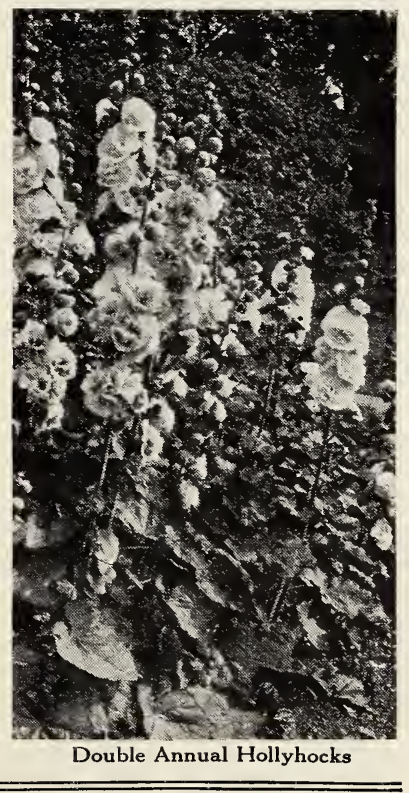




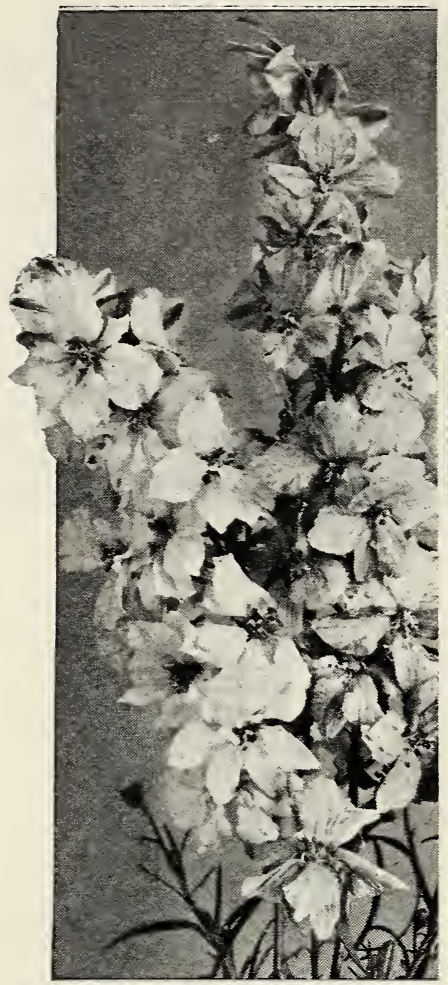

Emperor Branching Larkspur

The new colors of the Giant Hyacinth-flowered Larkspur are not only very rich but very interesting.

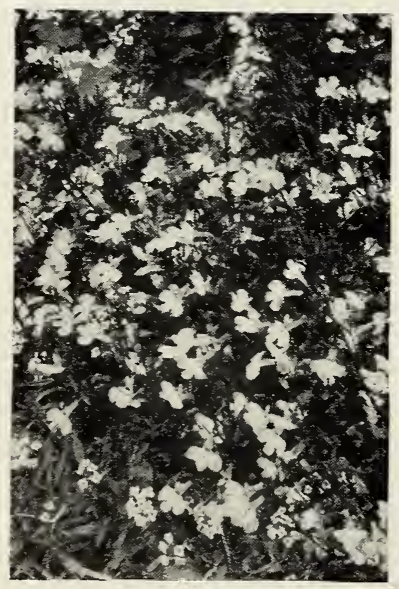

Lobelia, Crystal Palace Compacta

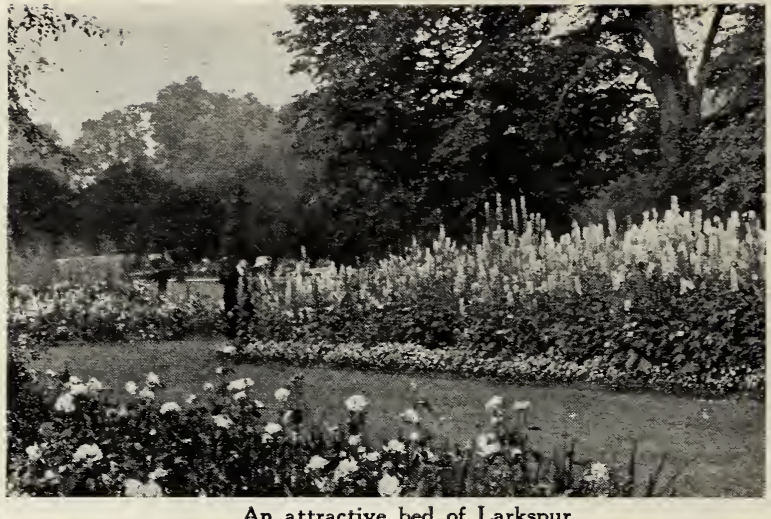

An attractive bed of Larkspur

\section{Larkspur • Annual Delphinium}

These tall, showy plants bloom freely during the summer months. The bright and attractive flowers, in shades of blue, rose, violet, and white, are fine for cutting. Seeds sown outdoors in April will flower by July and continue until frost. Thin out early to stand a foot apart. For perennial varieties, see Delphinium in Perennial List.

Giant Hyacinth-flowered. Grows 4 to 5 feet tall, with flowerspikes 18 to 24 inches long, in new and exquisite shades. Chocolate, Red-Grey, Tile-Red, White tinted Blue, Indigo. Each, pkt. 25 cts. COLLECTION : One pkt. each of the 5, \$1.

\section{Emperor Branching}

This grand type of Annual Larkspur grows about 2 feet high and is of candelabra habit. Rose, White, Blue, Violet-Purple, and Mixed. Each, pkt. 10 cts.; 1/4 oz. 35 cts.

Pink Delight. A new dwarf variety of delicate soft pink, shaded salmon. Pkt. 25 cts.; 5 pkts. \$1.

\section{Tall Double Stock-flowered}

Candelabra-like trusses of beautiful flowers for cutting and tall borders. Vigorous, early and free-blooming. Ht. $3 \mathrm{ft}$. Dark Blue, Sky-Blue, Lilac, Shell-Pink, Pure White, and Mixed. Each pkt. 15 cts.; $1 / 40 z .50$ cts.

La France. This bids fair to become the most popular of the annual Larkspurs. Its pleasing salmon-pink, a new shade in the stock-flowered class, will be much prized both for show purposes and for cutting. Pkt. 35 cts.

\section{Lavatera - Annual Mallow}

Splendens. Beautiful and showy annual, 2 feet high, producing profusely the entire summer, Iarge, cup-shaped flowers. Sow outdoors in May and thin to 1 foot. Bright Rose or Pure White. Each, pkt. 15 cts.; $1 / 4$ oz. 50 cts.

\section{Lobelia}

Exceedingly pretty, profuse-blooming plants for the garden and for hanging-baskets. These bloom very quickly from seed and flower all through the season. Sow indoors in March, and thin moderately; or transplant several inches apart in rich soil. Ht. 6 in. For Cardinal Flower see Perennial List. Crystal Palace Compacta. Rich deep blue; dark foliage. The finest variety for bedding. Ht. 6 in. Pkt. 15 cts.; $1 / 8 \mathrm{oz}$. $\$ 1$. Gracilis, Blue. Light blue flowers; bright green trailing foliage. Pkt. 15 cts.; $1 / 8$ oz. 75 cts.

Oculata. Pretty dark blue flowers with white eyes. Ht. 6 in. Pkt. 15 cts.; $1 / 8$ oz. 75 cts. 


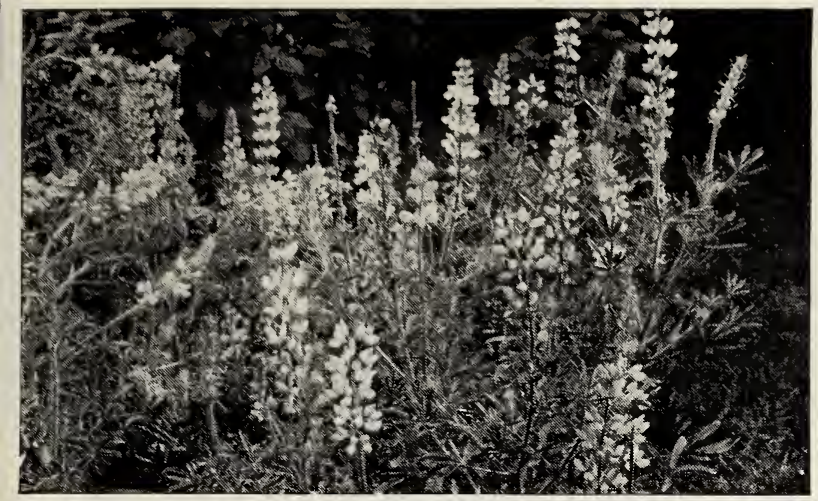

Annual Lupine

\section{Lupinus • Lupine}

Free-flowering, easfly-grown, with long, graceful spikes of rich and various-colored pea-shaped flowers. Valuable for mixed borders, beds and for cutting. Sow in the open in May and thin out, leaving about 1 foot between the plants. They bloom from June until September. Do not transplant. Ht. $2 \mathrm{ft}$. See Perennial List for other varieties.

Hartwegi. Blue, White, Rose, or Mixed. Each, pkt. 10 cts. Sulphur-Yellow. A charming new shade. Pkt. 25 cts.; 5 pkts. $\$ 1$.

\section{Marigold • Tagetes}

The French have the small, velvety flowers, in pretty combinations of yellow, brown, maroon, and striped effects; the African sorts are the enormous-flowered ones, in very showy orange and lemon shades. They bloom profusely all summer. Start the seed indoors, early in April, or outside when the weather is warm. Fine as cut-flowers and for beds.

\section{Double African}

Prize Strain. Because of its great improvement, this very excellent strain was given an Award of Merit by the Royal Horticultural Society. It produces bushy plants $21 / 2$ feet high, with enormous flowers, measuring 4 to 5 inches across, of great substance. Prize Strain Orange and Prize Strain Lemon. Each, pkt. 35 cts.; 3 pkts. \$1.

Orange Prince (orange), Lemon Queen (yellow), or Mixed. Ht. $21 / 2$ ft. Each, pkt. 10 cts.; $1 / 4$ oz. 50 cts.

\section{French}

Double Dwarf Gold-striped. Beautifully striped Ht. 10 in. Double Dwarf Golden Ball. Pure golden yellow. Ht. 10 in. Double Dwarf Dark Brown. Beautiful red-brown. Ht. 10 in. Double Dwarf Mixed. The finest assortment. Ht. $1 \mathrm{ft}$.

Legion of Honor (Little Brownie). A single Marigold of great beauty, bright yellow blotched with brown. Ht. 9 in. Each, pkt. $10 \mathrm{cts}$.; $1 / 4 \mathrm{oz} .50 \mathrm{cts}$.

\section{Matricaria - Feverfew}

These are free-flowering, fine for bedding or for pot culture. They bloom until cut down by frost. Ht. 2 to $3 \mathrm{ft}$.

Double White. Masses of double white flowers. Pkt. 10 cts.

\section{Matthiola}

Bicornis (Evening-scented Stock). These delicate lilac flowers resemble the Ten-Weeks Stock and are delightful for their fragrance. Sow indoors in March. Ht. $1 \mathrm{ft}$. Pkt. $10 \mathrm{cts}$.

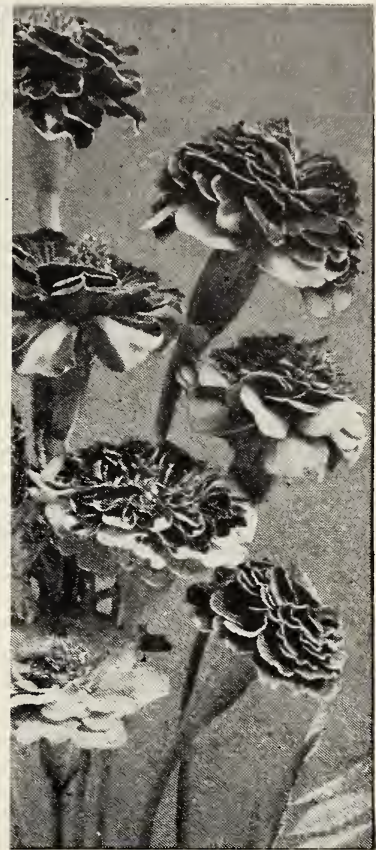

French Marigolds

French Marigolds are superb edging plants, making dense little bushes covered at all times with their showy little flowers. They are easy to transplant and a reserve supply may be raised to fill in places where other plants have failed.

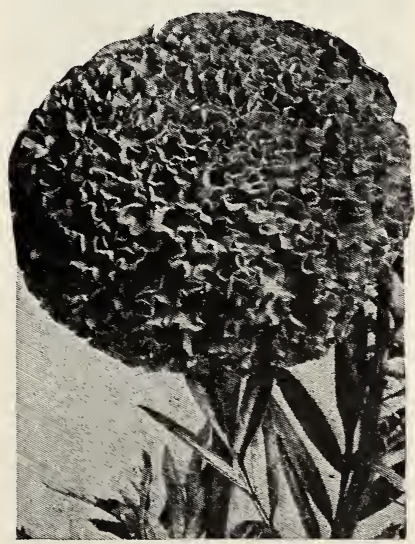

Double African Marigold 


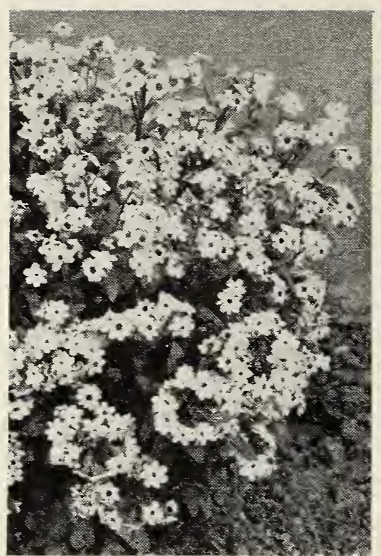

Myosotis (Forget-me-not)

Forget-me-nots are pretty in the rock-garden and transplant so easily when in full flower that a large reserve supply of them may be kept to move into places where other earlier flowers have passed out of bloom.

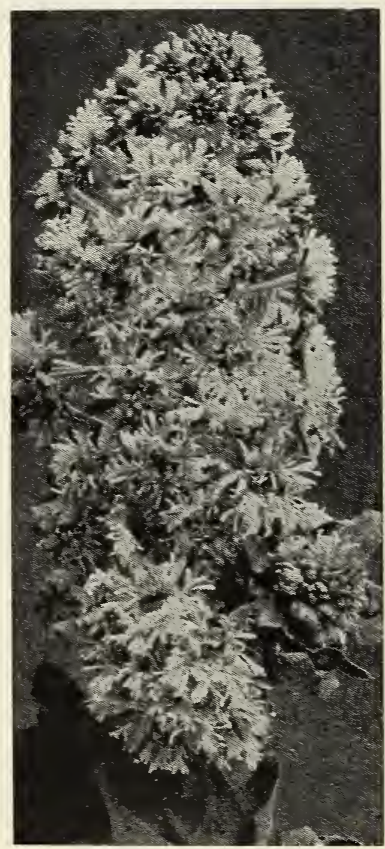

Defiance Mignonette

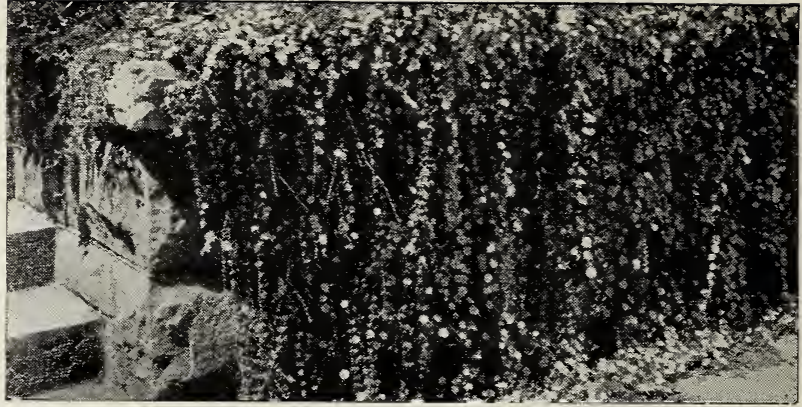

Mesembryanthemum crystallinum

\section{Mesembryanthemum • Ice Plant}

Crystallinum. Pretty, trailing, summer half-hardy annual for vases, hanging-baskets, and rock-work. Leaves covered with ice-like drops; flowers white. Sow indoors in March. Ht. 6 in. Pkt. 10 cts.; $1 / 4$ oz. 50 cts.

Tricolor. Cerise-flowering sort. Pkt. 10 cts.; $1 / 4$ oz. 50 cts.

\section{Mignonette - Reseda}

Its sweet, delicate fragrance makes this a favorite annual in every garden. Sow in May in the borders or any sunny spot where plants are to remain. It is also grown in pots for winter and early spring flowering. Mignonette prefers a medium light, loamy soil, with only a moderate amount of moisture. Bismarck. An extra-select, mammoth-flowering strain. Florets reddish green. Pkt. 15 cts.; $1 / 40 z .75$ cts.

Defiance. This gorgeous Mignonette is delightfully fragrant, with spikes from 12 to 15 inches long. The individual florets are of remarkable size and stand out boldly, forming graceful compact spikes which can be kept three weeks after cutting, retaining their grace and fragrance until every bud has opened. Pkt. 10 cts.; $1 / 4$ oz. 50 cts.

Machet, Giant-flowered Selected. A dwarf, vigorous French variety, with broad spikes of very fragrant reddish flowers. Pkt. 15 cts.; $1 / 4 \mathrm{Oz} .75$ cts.

Old-fashioned Sweet-scented. Dwarf, with many small spikes of extremely fragrant blossoms. Pkt. 10 cts.; oz. 50 cts.

\section{Mimulus}

A useful window and pot-plant, or for garden in a moist, shady situation. Blooms first year from seed if sown indoors March to ApriI. Ht. 6 to 12 in.

Moschatus (Musk Plant). Fragrant plant with smaII, yellow blooms. Pkt. 15 cts.

Tigrinus (Monkey Flower). Large spotted flowers of several colors. Pkt. 15 cts.

\section{Myosotis - Annual Forget-me-not}

Lovely little plants for moist and shady situations. Sow in March for April bloom or early summer for blooming Iater. Lift the plants in fall and pot for winter use. For hardy varieties see Perennial List.

Alpestris. Dwarf, compact, and much-branched, with Iarge, bright flowers. It flowers ten weeks after sowing. Blue, White, Rose, or Mixed. Each, pkt. 15 cts.; $1 / 40 z .75$ cts.

Alpestris, Victoria. Of dwarf, compact growth, with long sprays of bright flowers, produced in dense umbels. $\mathrm{Ht}$. 6 in. Blue or Rose. Each, pkt. 15 cts.; $1 / 4 \mathrm{oz}$. $\$ 1$.

Ruth Fischer. The finest and largest, producing flowers up to $1 / 2$ inch in diameter, of true Forget-me-not-blue. Plants of strong, vigorous growth, exceptional for pot culture and spring bedding. Pkt. 25 cts.; $1 / 8$ oz. \$2. 


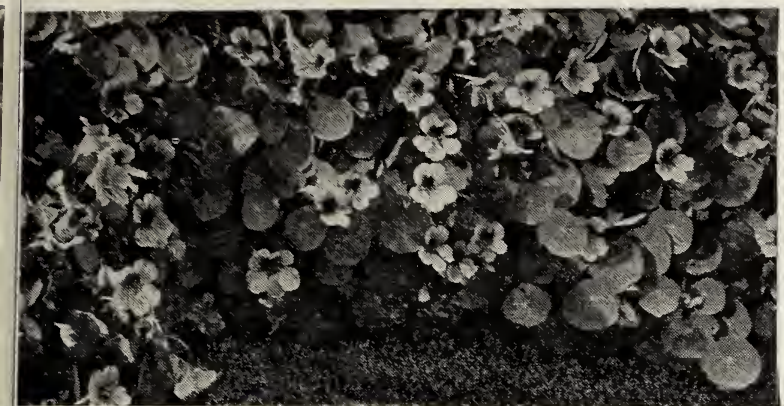

Border of Dwarf Nasturtiums

\section{Nasturtium - Tropaeolum}

The Nasturtiums deserve every bit of their immense popularity, for they will grow anywhere and produce an amazing number of brightly colored flowers for cutting. The tall or trailing varieties grow quickly and are most useful for screening unsightly fences and quickly covering waste spots. The dwarf sorts are fine for edging and massing. Gorgeous solid effects can be obtained by planting the separate colors. Sow the seed in the open ground in April.

Forbes Superb Dwarf Salmon, Scarlet, Crimson, Yellow, Cream, and Mixed. Each, pkt. 10 cts.; oz. 25 cts.; 1/4Ib. 75 cts.; Ib. $\$ 2$.

Forbes Superb Tall Salmon, Scarlet, Crimson, Yellow, Cream, and Mixed. Each, pkt. 10 cts.; oz. 25 cts.; 1/4lb. 75 cts.; Ib. $\$ 2$.

\section{Nemantirrhinum}

This interesting annual is the result of a cross between Nemesia strumosa and Tom Thumb Antirrhinum. It has the character of the Snapdragon but embraces aII of the colors of the Nemesia in combinations of yellow mottled brown, yellow tigered with red and pink, and white suffused with purple and carmine. The flower-spikes are very compact.

Erectum Mixed. The plants of this strain grow 12 to 15 inches high and as they bloom all summer they are fine for bedding purposes. Pkt. 50 cts.

Gracillimum. These are dwarf, compact plants about 8 inches high, with rich violet-purple blooms. Pkt. 50 cts.

\section{Nemesia}

Strumosa, Sutton's Hybrids. Flowers are 1/2inch across and are borne in great profusion. The color ranges from white through pale yellow and rose, to orange and crimson with numerous intermediate shades and a great variety of throat markings-16 colors in all. This South African plant is 2 feet high and blooms from June to September. Start the seed indoors in March and set plants out in May. This is a bedding annual suited for shady locations and for pot culture. Pkt. 25 cts.; 5 pkts. $\$ 1$.

\section{Nicotiana - Flowering Tobacco}

Beautiful border plants easy to grow from seed, used for pots and boxes. They do best on a deep, loamy soil and in a sheltered situation. Start the seed indoors in March, although late spring and fall sowings give good results. $\mathrm{Ht} .3 \mathrm{ft}$.

Affinis Hybrids. Brilliant colors, including pink and red shades in addition to pure white. In fuIl flower every sunny day from June until cut down by frost. Clusters of trumpetshaped, sweet-scented flowers on tall stems above the Iuxuriant foliage. Pkt. $10 \mathrm{cts}$.; $1 / 4 \mathrm{oz} .35 \mathrm{cts}$.

Affinis. The pure white form. Pkt. 10 cts.; $1 / 4$ oz. 35 cts.

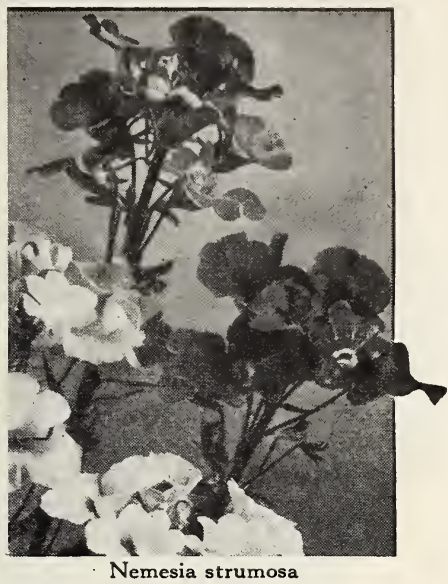

Black-Leaf 40

is indispensable for the destruction of black aphids or lice which sometimes come on Nasturtiums. One teaspoonful to 1 gallon of water, sprayed on the plants with regularity, will completely check these pests.

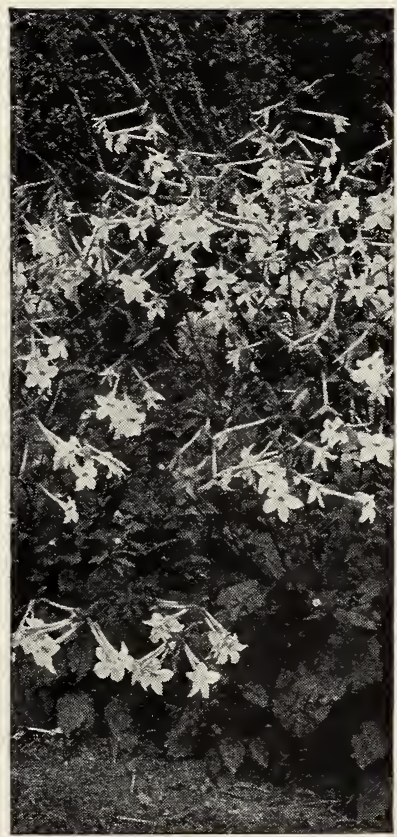

Nicotiana affinis 


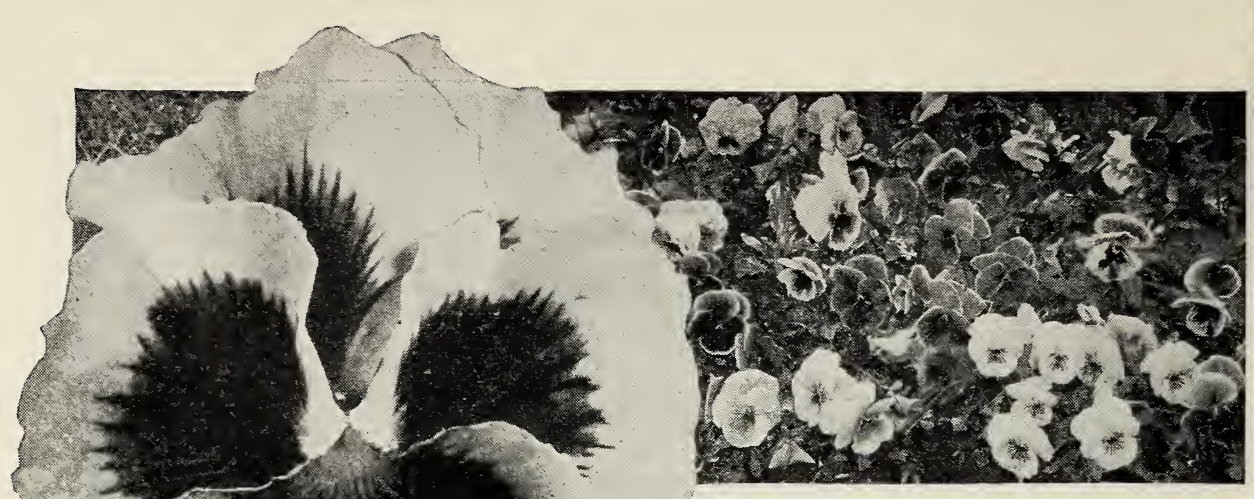

\section{Nigella $\cdot$ Love-in-a-Mist}

The seed-pods of some are curiously horned; and the black seeds are aromatic. Easily grown annual, blooming all summer. Ht. 15 in. Sow outdoors in April.

Miss Jekyll. Bushy plants, with clear cornflower-blue flowers of large size, surrounded by slender, mist-like Forbes Big Beauty Pansies foliage; lovely for cutting. Pkt. 10 cts.; 1/4 oz. 50 cts.

Pansies may be sown in August or September and the plants set in a coldframe or wintered over in the open ground with hay protection or by hilling. They will bloom very early in the spring. If old plants are moved to the frame in autumn, an abundance of lovely flowers may be cut on sunny days in midwinter.

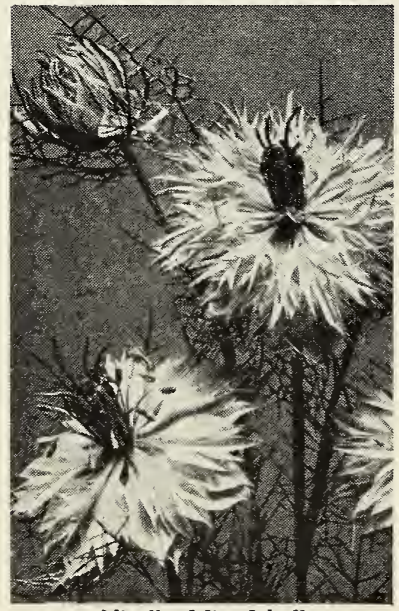

Nigella, Miss Jekyll

\section{The Finest Pansies}

After careful comparison of the seed strains from all available sources, we thoroughly endorse these mixtures and highly recommend them as the best available.

For Seed-Bed Culture. Use 6 inches of clean, pulverized soil, covered with 1 inch of compost. Over this spread $1 / 2$ inch best soil and roll smooth. Saturate bed deeply. Sow seed and cover lightly with clean sand. Keep surface continually moist but not soggy. Never allow it to dry out. Dust surface with sulphur or use Semesan to prevent damping-off. During germination, shade bed with lath or muslin sheeting and ventilate to avoid having a temperature of over 75 degrees. Set plants out when showing three to four leaves.

Forbes Big Beauties. These are gigantic blooms, the largest of all, on strong, stocky, compact plants of exceptional vigor. A wonderful array of color combinations--bronze, silver, gold and copper; wine-red, pink, salmon, silver-grey, brown-beautifully blotched, mottled, and bordered-in these colors so unusual in Pansies. The flowers, often 4 inches across, are perfectly formed and held above the plants on very long, stout stems. Pkt. 75 cts.; $\frac{1}{16} \mathrm{Oz}$. $\$ 1.75$.

Cassier's Blotched. Large, round flowers of bright colors, with a distinct dark blotch at the base of each of the five petals. Pkt. 25 cts.; $1 / 8$ oz. $\$ 1.25$.

Masterpiece. (Frilled.) Elegantly frilled and curled, and rich in mauve, red, and velvety brown. Pkt. 25 cts.; $1 / 8 \mathrm{oz}$. $\$ 1.25$.

Non Plus Ultra. Besides a good share of strains, such as Masterpiece, Bugnot, and Cassier, this mixture contains all the self colors such as white, yeliow, blue, purple, red, bronze, etc. Pkt. 25 cts.; $1 / 8$ oz. \$1.25.

Swiss Giants. The flowers of this strain are enormous, over 3 inches across, perfectly round with overlapping petals, borne well above the foliage. It includes many new combinations-salmons pinks, reds, and no self colors. All flowers are three or five-blotched. Pkt. 50 cts.; 1/8oz. $\$ 2.25$.

Trimardeau Giants. Flowers of giant size with round, overlapping petals. The compact plants are vigorous and freeblooming. In separate colors: Light Blue, Dark Blue, Yellow and Purple, Golden Yellow, Indigo-Blue, Jet Black, Lavender, Mauve, Purple, Ruby Shades, and Mixed. Each, pkt. 15 cts.; $1 / 8$ oz. 75 cts. 


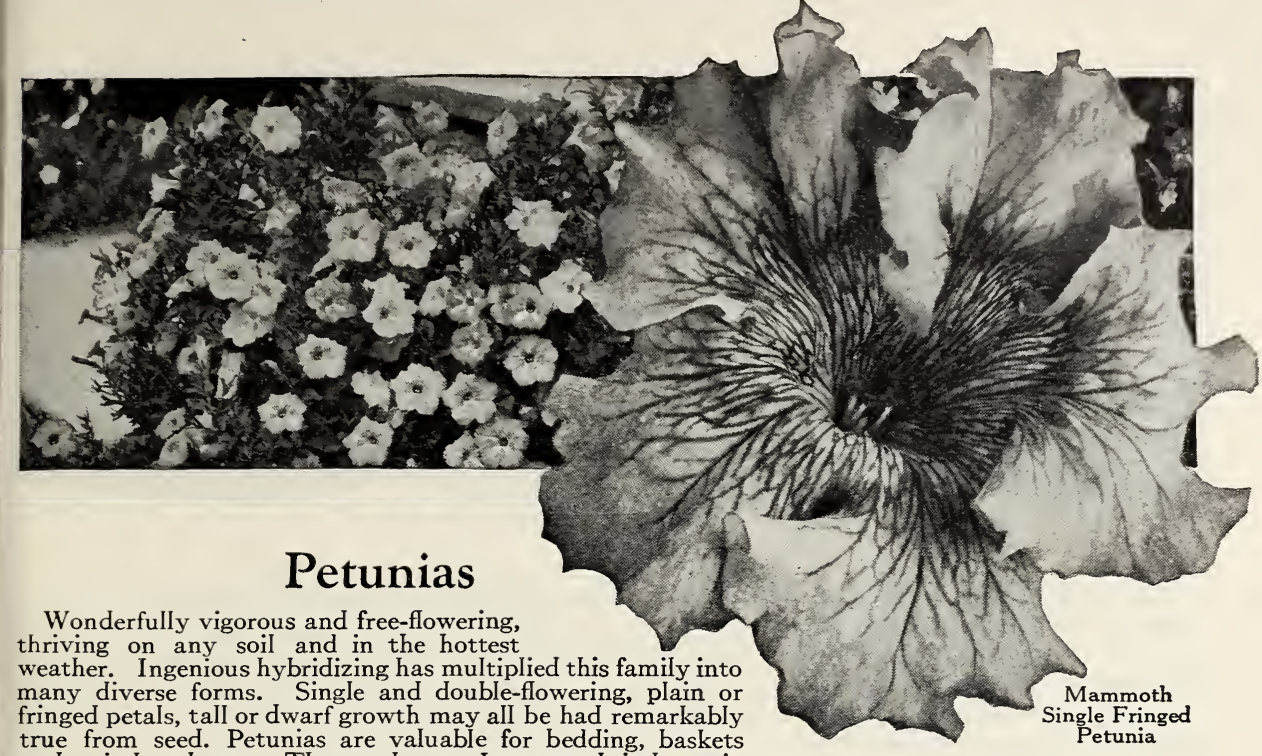
and window boxes. The seed may be started indoors in February or March or sown in the open in early May. Handle the seed very carefully as it is very fine.

\section{Balcony Petunias}

Free-blooming, trailing in growth, with single flowers 3 inches across. Particularly suited for hanging-baskets, porchboxes, etc., and showy in beds.

Balcony White, Rose, Crimson, or Mixed.

Balcony Blue. An outstanding variety, with Iarge flowers of a beautiful, clear violet-blue color.

Each, pkt. 25 cts.; $1 / 80 z . \$ 1.50$

\section{Giant-flowering Fringed Petunias}

The individual beauty of these mammoth Petunias makes them highly desirable. They are easily grown from seed sown in pots indoors about February or March and transplanted to the garden Iater. The seed is extremely fine and should be covered very lightly.

\section{Single Varieties}

Whether desired for bedding, cutting or general display, these are the finest varieties of the Fimbriata, or fringed large-flowering class.

Dwarf California Giants. This wonderful strain of Petunias produces very dwarf, compact plants only 4 inches high. The huge, fringed single blooms are beautifully veined on self-colored grounds. This is unquestionably the finest single fringed Petunia for pot-culture. Pkt. 75 cts.

Mammoth Single Fringed White, Rose, or Crimson. Each, pkt. 25 cts.

Mammoth Single Fringed Mixed. A mixture of best fringed varieties including many new shades. Pkt. 25 cts.

\section{Double Varieties}

Seed saved from the most carefully hybridized flowers produces only 30 per cent of double-flowering plants. Save the weaker seedlings, as these produce the finest flowers.

Double Fringed Prize Giant White, Rose, or Crimson. Each, pkt. 50 cts.

Double Fringed Prize Giant Mixed. Pkt. 50 cts.

Be sure to save the weakest and most unpromising seedlings of the Fringed and DoublePetunias. These weaklings are the ones which will produce the finest flowers. With a little encouragement they will grow quickly into strong, sturdy, and productive plants bearing flowers of magnificent size and color.

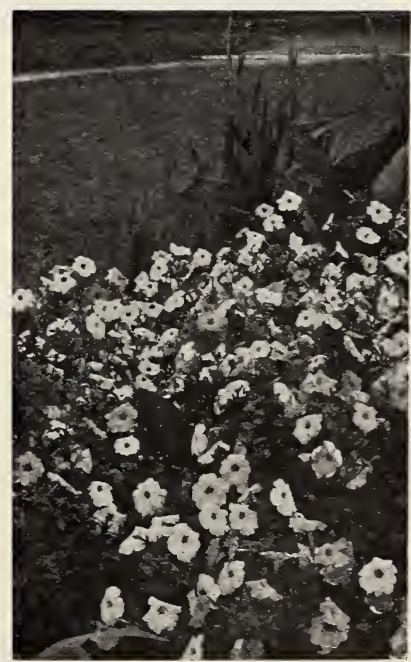

Petunia Bed 


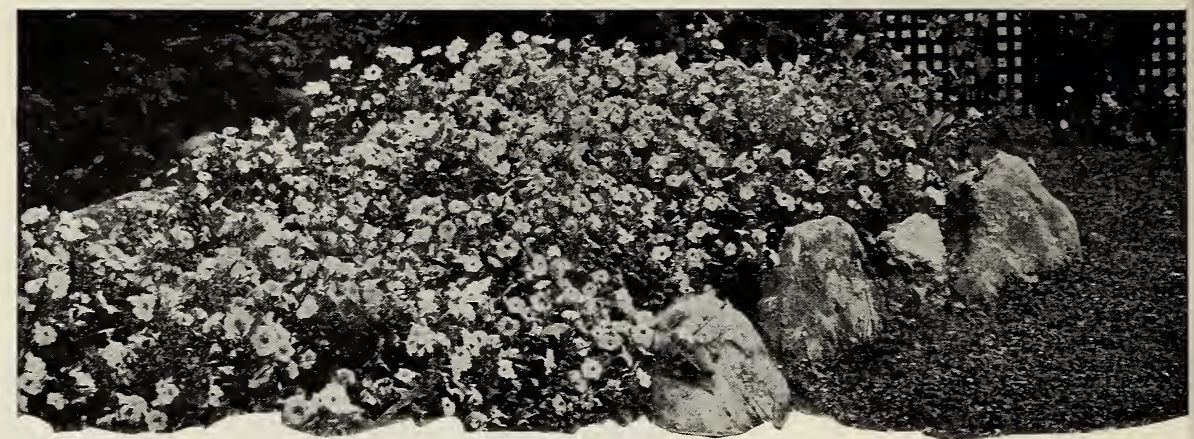

A nice planting of Single Bedding Petunias

One of the prettiest combinations in the garden is one of the Pink Petunias, Rosy Morn or Rose of Heaven, grown with ageratum. The combination of soft shades of blue and pink is exquisite. Those who like scarlet geraniums will find white Petunias a perfect foil for them. Violet Queen looks exceptionally weIl combined with sweet alyssum, but perhaps the most interesting way to grow Petunias is in a kaleidoscopic mixture of all varieties.

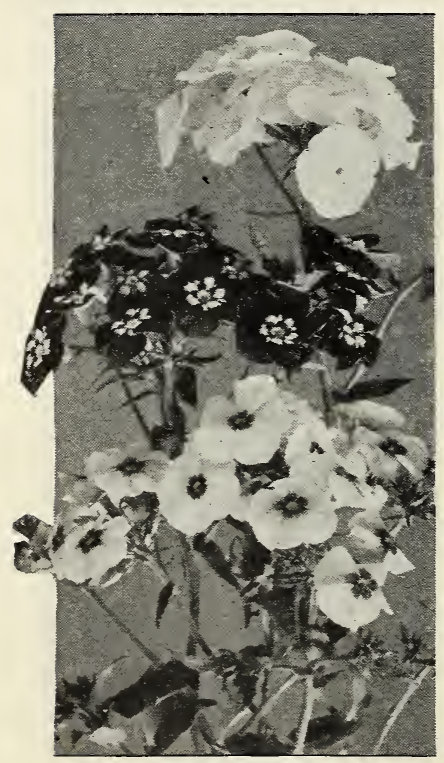

Phlox Drummondi

\section{Single Bedding Petunias}

Dwarf, neat, compact bushes covered with a multitude of small flowers all summer, valuable for edging and bedding.

Special Dwarf Bedding, Mixed. Very showy little flowers blooming profusely on compact bushy plants. Ht. 10 in. Pkt. 15 cts.; $1 / 402.75$ cts.

Howard's Star. Rich crimson, with distinct white star in center. Ht. 10 in. Pkt. 15 cts.; $1 / 4$ oz. 75 cts.

Rose of Heaven. This excellent variety has real outstanding merit. The plants are dwarf, compact, and free-flowering, with blooms of brilliant rose-pink, 4 to 5 inches across. This strain is superior to Rosy Morn. Pkt. 25 cts.; 5 pkts. $\$ 1$.

Rosy Morn, Improved. Bright rosy pink, white throat; compact and free-flowering. Ht. 8 in. Pkt. 20 cts.; $1 / 4 \mathrm{oz}$. \$1.25. Snowball. A fine compact sort, with pure white flowers throughout the season. Ht. 6 in. Pkt. 20 cts.; $1 / 4 \mathrm{oz}$. \$1.25.

Striped and Blotched. Variously colored attractive flowers. Ht. 8 in. Pkt. 20 cts.; 1/40z. \$1.25.

Violacea. A beautiful steel-blue or deep violet, with no trace of magenta. Ht. 8 in. Pkt. 20 cts.; 1/40z. \$1.25.

Violet Queen. Remarkable for its true violet-blue that will not fade when exposed to the sun. The deep-throated flowers are very large, measuring 3 to 4 inches across. It is exceptionally fine for bedding and window-boxes in combination with Rose of Heaven. Pkt. 50 cts.; 5 pkts. \$2.

\section{Phlox Drummondi}

For a color effect in the garden there is nothing quite so brilliant and quite so lasting. The plants produce their slender flower-stems in numbers on a single plant, each being crowned with an umbel of large, perfumed blooms, which resemble a hardy Phlox. They succeed best in a sunny open situation, and seeds, sown outdoors in May, will produce a solid sheet of color from July until frost. They are fine for cut-flowers.

\section{Large-flowering Tall Varieties}

This is the finest type, having the largest heads of bloom; of strong, sturdy growth, attaining a height of about 15 inches.

Grandiflora. Dazzling in effect when borders are sown with contrasting harmonizing colors. Rich Purple, Bright Scarlet, Brilliant Rose, Pure White, Deep Crimson, BuffYellow, or Mixed. Each, pkt. 10 cts.; $1 / 4 \mathrm{oz}$. 75 cts.

\section{Large-flowering Dwarf Varieties}

PIants of this charming section grow 6 to 8 inches high and produce dense masses of bloom all summer. They are excellent for beds, edgings, and pots.

Nana compacta. Resembles the tall sorts in size of blooms but the plants are dwarfer. Brilliant Rose, Bright Scarlet, Pure White, or Mixed. Each, pkt. 15 cts.; 1/4oz. \$1.25. 


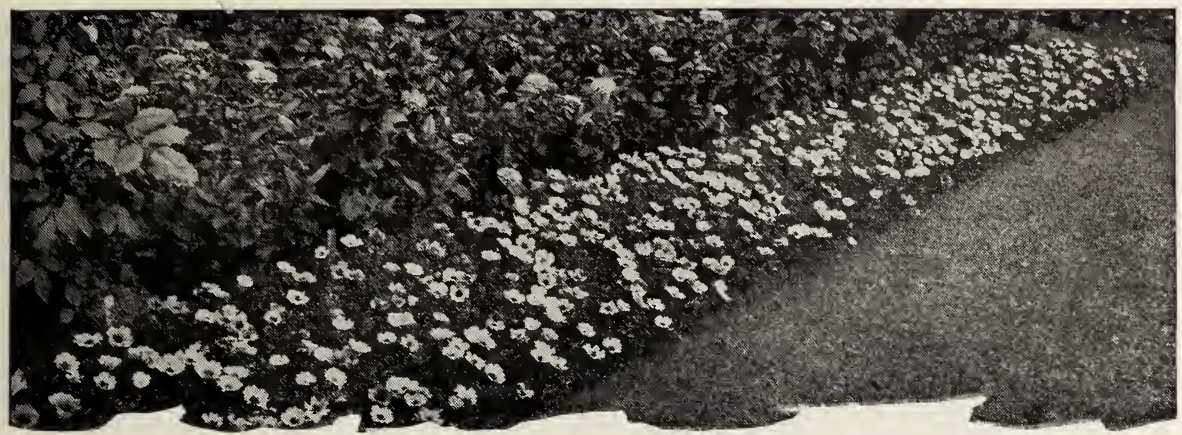

An attractive Single Portulaca border fronting a bed of Zinnias

\section{Poppy - Papaver}

Few flowers have the same grace of stem, airiness of poise, and delicacy of tissue as the Poppy. For beds and borders, with a background of green, there is nothing finer. A sandy loam suits Poppies best, and as their strong taproots are difficult to transplant, the seed should be sown where the plants are to bloom. Sow the seed thinly outdoors in September or March, cover lightly, and thin to a foot apart.

\section{Single Varieties}

For flaming brilliancy, Poppies have no rivals among the annual flowers. Some varieties are suitable for cutting; the Shirleys, in particular, if picked early in the morning with the buds just showing color, last weII in water.

Annual Oriental. (New.) These huge red Poppies, like the perennial Oriental Poppies, are of great substance, but remain in bloom two weeks longer. Pkt. 25 cts.; 5 pkts. $\$ 1$. Shirley Improved. A great favorite, coming in many beautiful shades-rose, salmon, apricot, pink, crimson, red with white margin, etc. Ht. $2 \mathrm{ft}$. Pkt. 10 cts.; $1 / 4 \mathrm{oz} .35$ cts.

Tulip Poppy. Flowers 3 inches across, resemble the brilliant scarlet Gesneriana tulip. Ht. 2 ft. Pkt. 10 cts.; $1 / 4$ oz. 35 cts.

Yellow Tulip Poppy. See Hunnemannia.

Single Mixed. Ht. 2 ft. Pkt. 10 cts.; 1/4 oz. 35 cts.

\section{Double Varieties}

Whereas the single Poppies are most fragile in appearance, and the airiest flowers imaginable, the double sorts are firmpetaled and last weII on the plants and after cutting.

Carnation-flowered, Mixed. These large, ball-shaped, double flowers have beautifully fringed petals and come in a variety of shades, many striped. Pkt. 10 cts.; 1/4 oz. 35 cts.

New Double Hybrids. These brilliantly colored, fluffy, ballshaped flowers are beautifully fringed and unusually Iarge. They come in lovely shades of mauve, red, pink, terra-cotta, and some are striped and penciled. Sow the seed outdoors in April and again in Iate May. Pkt. 25 cts.; 5 pkts. \$1.

Peony-flowered, Mixed. These Iarge, showy, double globular flowers, like a double peony, are adapted for large beds or shrubbery borders. Ht. 2 ft. Pkt. 10 cts.; $1 / 4 \mathrm{oz} .35$ cts.

Ryburgh Hybrids. Resemble giant carnations with flat petals overlapping, like a double begonia, in shades of pink, salmon, and orange. Ht. 2 ft. Pkt. 15 cts.; $1 / 4$ oz. 50 cts.

\section{Portulaca}

This charming little hardy annual is unrivaled for brilliancy among plants of low growth. Hot sun with light, sandy soil is best. The seed does not germinate until hot weather, and should be sown in April. Ht. 6 in.

Large-flowering Single, Mixed. For masses of color in beds and on rockeries. Pkt. 10 cts.; $1 / 4$ oz. 50 cts.

Large-flowering Double, Mixed. The doubleness of the flowers gives heavier color. Pkt. 15 cts.; $1 / 80 \mathrm{oz} .75 \mathrm{cts}$.
Some people claim they have transplanted Annual Poppies successfully, but most people can not. Sow the seed as thinly as possible, and be sure to thin the seedlings rigorously or the plants will be slender and anemic. The Shirley Poppies are the most dainty, and will keep if cut in the bud and each stem charred by a match flame for an inch or so, back of the cut end. The brilliant colors found in Poppies afford a wonderful opportunity for spots of bright color in the border. The color may be accentuated by locating the Poppies immediately in front of dark foliaged shrubs.

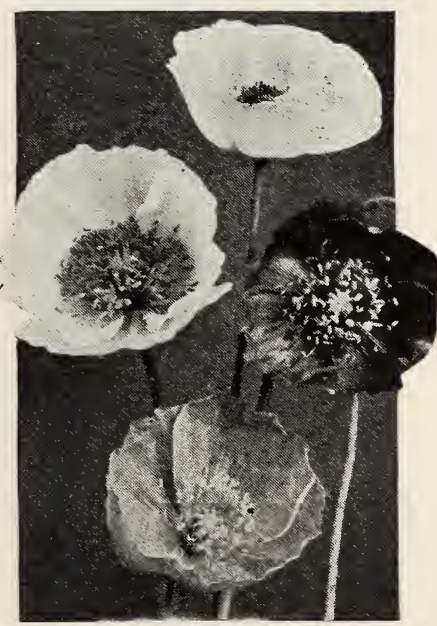

Single Annual Poppies 


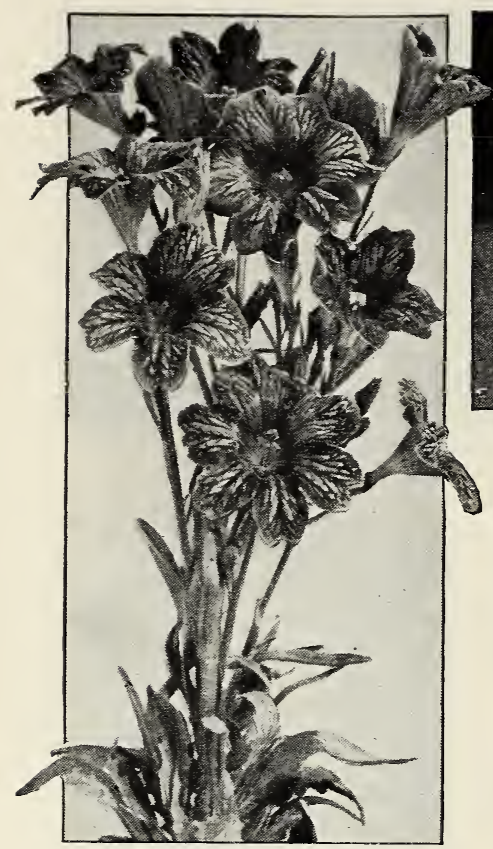

Candelabra Salpiglossis

The Scarlet Sages are extremely popular for showy bedding effects. Few plants are more cheerful or more colorful than Salvia.

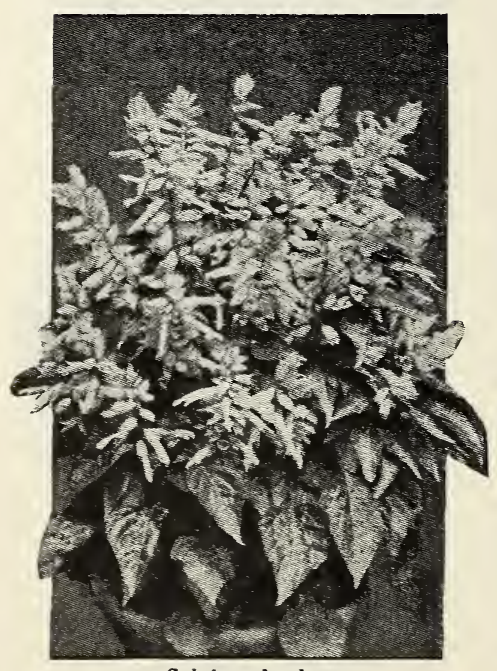

Salvia splendens

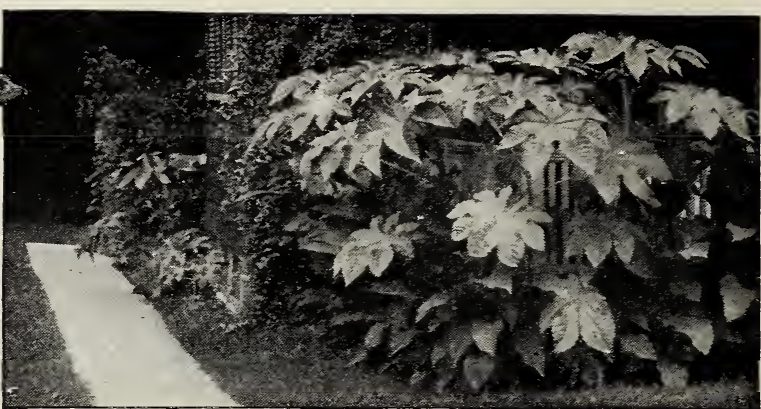

\section{Ricinus - Castor-Oil Bean}

This picturesque, showy and imposing foliage plant resembles a magnificent semi-tropical shrub. As a specimen it makes a pyramid of gigantic star-like leaves; planted thickly it forms a screen. Sow the seed in pots indoors in March.

Cambogensis. Large leaves of a bronzy red-maroon. Ht. $5 \mathrm{ft}$. Zanzibarensis, Mixed. Enormous leaves, light green to purplish red. Ht. 12 to $14 \mathrm{ft}$. Each, pkt. 10 cts.; $1 / 20 z .25$ cts.

\section{Rhodanthe. See Everlasting Flowers.}

\section{Salpiglossis - Painted Tongue}

These showy plants from Brazil bear beautiful, funnelshaped flowers having dark veins on a ground which varies from white to crimson, yellow, orange, and blue. Of easiest culture, succeeding in any good soil in a sunny position, and bloom freely from midsummer until frost. Splendid for cutting. Sow outdoors in spring and thin to stand 1 foot apart.

Candelabra. Instead of branching out from the bottom, the plants send up a strong center stem. The side branches are full of beautifully marked, large, petunia-like flowers. The whole plant has a wonderful stately appearance in the border. The flowers are larger than the ordinary Salpiglossis, and the colorings include the finest orchid shades. In 6 separate colors: Blue and Gold, Chamois, Crimson and Gold, Golden Yellow, Violet and Gold, Scarlet and Gold, and Mixed. Each, pkt. 25 cts.; all 6 for $\$ 1.25$.

Grandiflora Mixed. A good mixture of choice colors. Ht. $2 \mathrm{ft}$. Pkt. 10 cts.; $1 / 4$ oz. 50 cts.

\section{Salvia - Sage}

One of our most handsome summer and autumn-flowering plants, Iiterally ablaze with brilliant flowers. Sow seed early in boxes, transplant to small pots, and set out when frost is past; or sow outdoors in May. Avoid excessive moisture.

America (Globe of Fire). This fine variety is greatly prized for its compact growth. The plants develop into a globeshaped bush surmounted by a profusion of sturdy, flamered flower-spikes. It is the earliest and the most brilliant of all red Salvias. Pkt. 25 cts.; $1 / 8$ oz. $\$ 1$.

Bonfire. The finest Salvia for bedding. Very compact, oval bushes about $2 \frac{1}{2}$ feet high, with long spikes of brilliant scarlet flowers. Gorgeous effects can be produced with massed Bonfure Salvia. Pkt. 15 cts.; $1 / 8$ oz. 75 cts.

Farinacea, Blue. Used as an annual in northern latitudes. See Perennial List. Pkt. 15 cts.; 1/80z. 75 cts.

Splendens (Scarlet Sage). Well-known bedding plants carrying long flaming flower-spikes, making a fine display until frost. Ht. 3 ft. Pkt. 10 cts.; $1 / 8$ oz. 60 cts.

Zurich. Dwarf scarlet variety, flowering early. Ht. $2 \mathrm{ft}$. Pkt. 25 cts.; $1 / 8$ oz. \$1. 

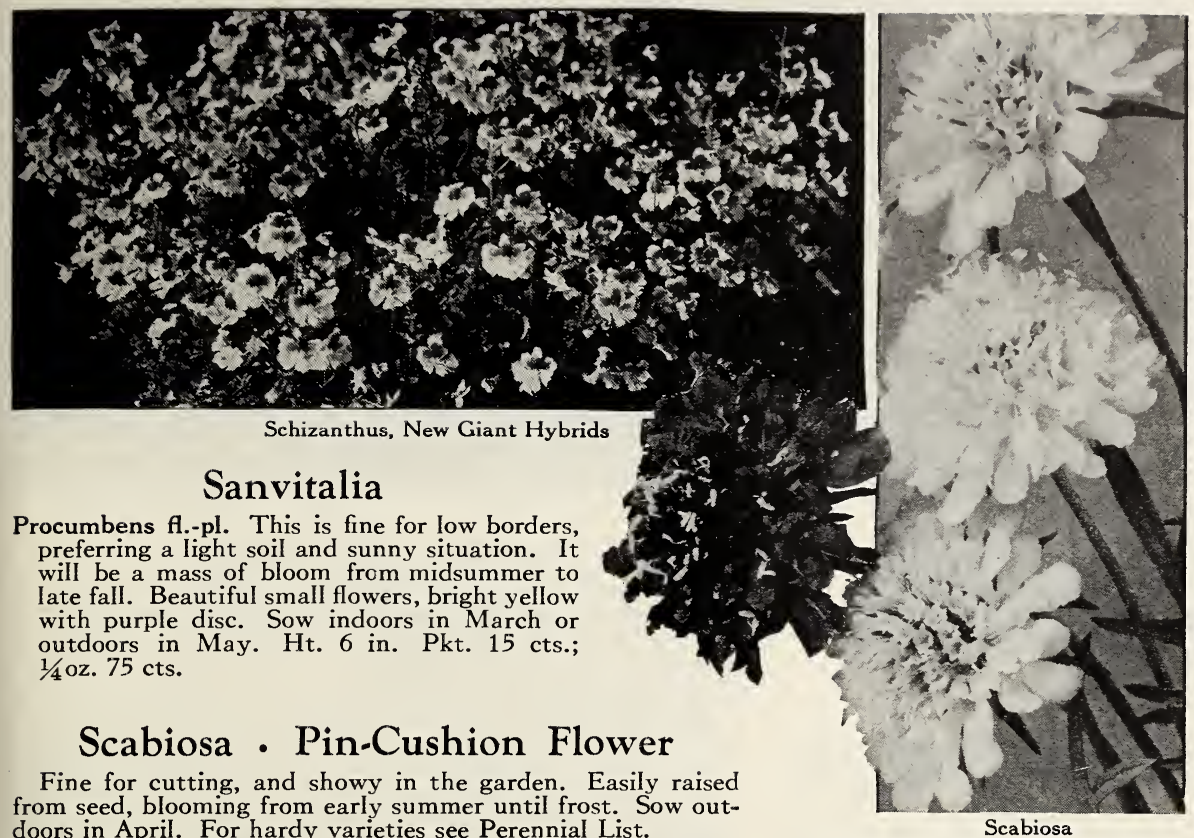

\section{Sanvitalia}

Procumbens fl.-pl. This is fine for low borders, preferring a light soil and sunny situation. It will be a mass of bloom from midsummer to late fall. Beautiful small flowers, bright yellow with purple disc. Sow indoors in March or outdoors in May. Ht. 6 in. Pkt. 15 cts.; $1 / 4$ oz. 75 cts.

\section{Scabiosa - Pin-Cushion Flower}

Fine for cutting, and showy in the garden. Easily raised from seed, blooming from early summer until frost. Sow outdoors in April. For hardy varieties see Perennial List.

Improved Giant-flowered. BeautifuI, full-petaled flowers are held erect on long, wiry stems and are fine for cutting. Rose, Crimson, Lavender, White, Yellow, Black-Purple, and Mixed. Each, pkt. 10 cts.; $1 / 4$ oz. 50 cts.

Peach Blossom. A beautiful peach-blossom-pink. Very large, perfect blooms on long stems. Pkt. 25 cts.; 5 pkts. \$1.

Shasta. A pure white of enormous size for a Scabiosa. The flowers, are 3 to $31 / 2$ inches across. Pkt. 25 cts.; 5 pkts. $\$ 1$.

\section{Schizanthus - Butterfly Flower}

This, one of the daintiest of annuals, is a mass of small bright flowers in a bewildering range of colors. The foliage is delicate and fern-like. Sow in May outdoors. For other varieties, see list of Flower Seeds for Greenhouse Culture.

New Giant Hybrids, Mixed. Bright, showy butterfly-like blooms. Ht. $11 / 2$ ft. Pkt. 10 cts.; $1 / 4$ oz. 35 cts.

\section{Silene - Catchfly}

Armeria, Mixed. A very showy, early-flowering hardy annual, bearing beautiful white, pink, and red tubular flowers having a spicy scent; excellent for cutting. Sow outdoors in April. Ht. $11 / 2$ ft. Pkt. 10 cts.; $1 / 4$ oz. 35 cts.

\section{Statice - Sea Lavender}

Its cloud-like masses of flowers make borders gay for a long time, and their delicate coloring and light graceful habit make them fine for bouquets. Sow indoors in March. For hardy varieties see Perennial List.

Bonduelli. Golden yellow flowers above a rosette of deeply cut, glaucous leaves. Pkt. $15 \mathrm{cts}$; $1 / 4 \mathrm{oz} .75 \mathrm{cts}$.

Sinuata, True Blue. Beautiful rich navy-blue which does not readily fade. Fine annual for cut-flowers or everlasting bouquets. Ht. $1 \mathrm{ft}$. Pkt. 25 cts.; 5 pkts. $\$ 1$.

Sinuata rosea superba. Delicate pink. Pkt. 25 cts.; 5 pkts. $\$ 1$.
If the Statices are cut and dried while the flowers are fresh, they make very unusual winter bouquets, different from the commonly known Straw Flowers.

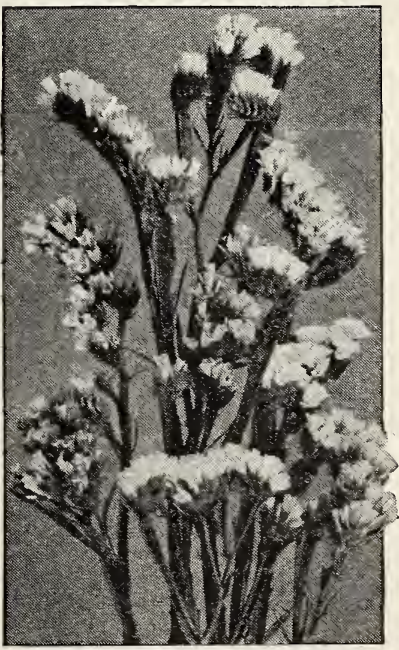

Statice sinuata, True Blue 


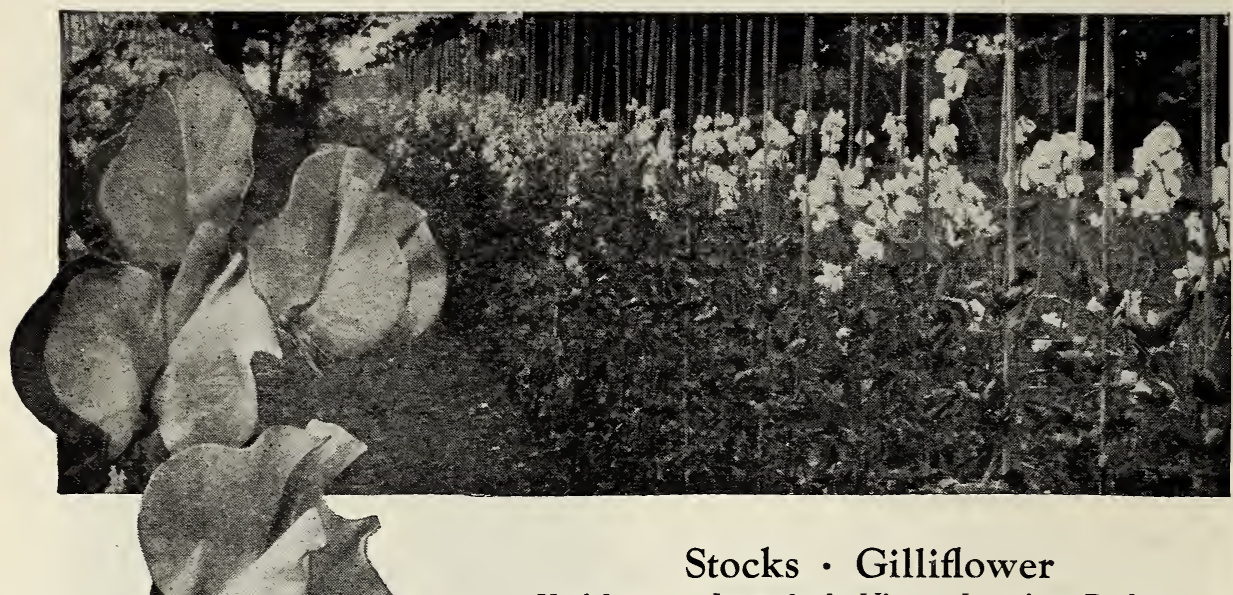

Useful as pot-plants, for bedding and cutting. Do best on a medium-light soil, with plenty of moisture and some shade in hot weather. Start seed indoors in March or sow outdoors in late ApriI. AII are very fragrant.

Large-flowering Dwarf Ten-Weeks. Particularly suited for beds and borders. Plants pyramidal in growth, about 10 inches high, very free-flowering, producing a high percentige of doubles. Light Blue, Canary-Yellow, Bright Pink, Erilliant Rose, Flesh-Pink, Carmine, Salmon-Pink, White, Purple, or Mixed. Each, pkt. 15 cts.; 1/80z. 75 cts.

Improved Giant Perfection (Cut-and-Come-Again). Pyramidal branching growth, with large spikes of double flowers from early summer to fall. Ht. $2 \mathrm{ft}$. Silvery Lilac, Rose, CanaryYellow, White, or Mixed. Each, pkt. 25 cts.; 1/8oz. \$1.

Fine Mixed for Open Ground. Pkt. 10 cts.; 1/4 oz. 50 cts.

\section{Forbes Sweet Peas}

The skill of the hybridizer has wrought marvelously in the development of this beautiful flower. The range of color, combined with the exquisite beauty of form of the flowers, and the gracefulness of the stems and tendrils, makes this the most popular of all our annual flowers. Ht. 5 to $7 \mathrm{ft}$.

Dig a trench 18 inches deep and fill with best loam, enriched with bone-meal or weIl-rotted manure. Drill in rows 5 inches deep; cover 2 inches deep. As vines grow, gradually fill trench with soil, and thin to 5 inches apart. For early flowers sow in November, in a dry situation, 6 to 8 inches deep, giving leveI culture. Make spring sowings as early as possible.

\section{Early or Winter-flowering Spencers}

This is a very choice selection of the most improved varieties grown for early flowering outdoors or winter bloom inside.

Aviator. Dazzling crimson-scarlet. Pkt. 25 cts.; oz. \$1.

Burpee's Orange. Clear orange. Pkt. 35 cts.; oz. \$2.50.

Giant Rose. Rich, deep rose-pink. Pkt. 35 cts.; oz. $\$ 2.50$.

Gilda Gray. Salmon-cerise over pink. Pkt. 35 cts.; oz. $\$ 2.50$. Grenadier. Bright dazzling scarlet. Pkt. 25 cts.; oz. \$1.50.

Harmony. Clear bright lavender. Pkt. 25 cts.; oz. \$1.

Jeanne Mamitsch. Bright rich pink. Pkt. 25 cts.; oz. $\$ 1$.

Mrs. Kerr. Clear salmon. Pkt. 25 cts.; oz. $\$ 1.50$.

Orange King. Rich deep orange. Pkt. 35 cts.; oz. \$2.50.

Snowstorm Improved. Best white. Pkt. 25 cts.; oz. \$1.

True Blue. Rich, clear blue. Pkt. 25 cts.; oz. \$1.

White Harmony. Pure white. Pkt. 35 cts.; oz. \$2.50.

Zvolanek's Rose. Deep pink. Pkt. 25 cts.; oz. \$1.50.

Forbes Early-flowering Mixed. Pkt. 15 cts.; oz. 75 cts.; $1 / 4$ Ib. $\$ 2.50$; Ib. $\$ 9$.

Improved Giant Perfection Stock 


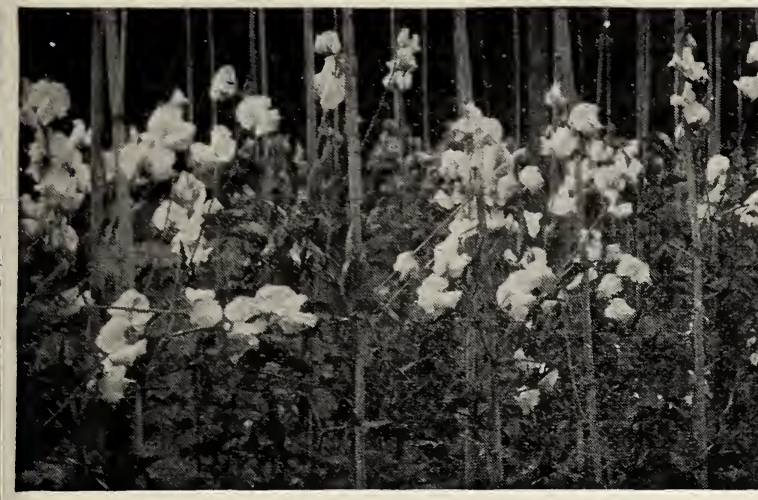

\section{Forbes Sweet Peas}

\section{Late or Summer-flowering Spencers}

This list contains the most desirable varieties, many of recent introduction and some of the older ones which still lead in their colors. AII of them produce magnificent blooms in great abundance. These varieties afford a very choice selection of colors.

Asta Ohn. Pinkish lavender blooms of great beauty.

Austin Frederick Improved. A strong growing Iavender sort. Blue Bird. Fine new real blue.

Campfire. Bright sunproof scarlet. Pkt. 15 cts.; oz. 75 cts.

Charity. Rich brilliant crimson.

Commander Godsall. A rich shade of deep violet-blue. Constance Hinton. A pure white variety, with black seed. Elfrida Pearson. Charming blush-pink blooms on strong vines.

Grenadier. A striking shade of bright geranium-red.

Hawlmark Cerise. Salmon-cerise.

Hawlmark Salmon-Pink. Lovely soft shade of salmon-pink. Hebe. Luminous, clear pink.

Jean Ireland. A delicate combination of cream, edged rose.

King White. Giant pure white.

Majestic Cream. Deep cream.

Mary Pickford. Cream-pink and salmon. Pkt. 25 cts.; oz. \$1.

Miss California. Salmon-pink. Pkt. 15 cts.; oz. 75 cts.

Mrs. Tom Jones. An unusually beautiful delphinium-blue.

Picture. Bright pink on cream.

Royal Purple. Striking Iarge blooms of rosy purple.

Royal Scot. Brilliant blooms of cerise-scarlet.

Tangerine, Improved. Salmon-orange. Pkt. 15 cts.; oz. 75 cts. The Sultan. Glossy back-maroon.

2 L O. The best glowing scarlet. Pkt. 15 cts.; oz. 75 cts.

Valentine. A pleasing shade of light shell-pink.

Any of the above, unless otherwise noted, pkt. $10 \mathrm{cts}$.; oz. $50 \mathrm{cts}$.

Forbes Giant Spencer Sweet Pea Mixture. This Mixture includes only the most effective colors of the Giant Spencer varieties, many of them producing three to four blooms on a stem. The flowers are of large size and excellent for cutting. Pkt. 10 cts.; oz. 30 cts.; $1 / 4$ lb. 85 cts.; Ib. $\$ 3$.

\section{Annual Sweet William . Dianthus}

These are strong, sturdy growers which require a moderate amount of sunshine and bloom from early summer until fall. Seed may be sown in early spring or in the faII. Transplanting, when necessary, must be done while the plants are quite small.

Barbatus sinensis, Single Mixed (Chinese Pink). A hybrid between Diantbus barbatus and $D$. plumarius, growing about 16 inches high and of the same habit as the perennial kinds. The white and scarlet flowers are borne in clusters. Pkt. 15 cts.; $1 / 4$ oz. 50 cts.

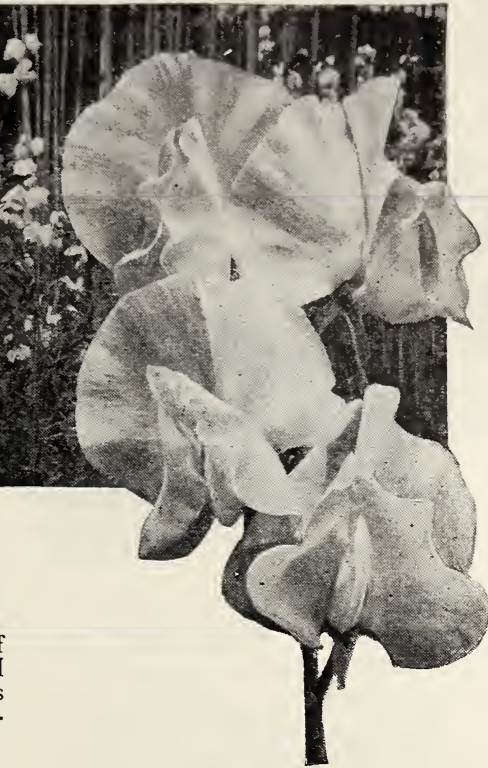

For general garden use, Sweet Peas in mixture are very satisfactory, but the loveliest cut-flower arrangements are possible when favorite varieties are grown separately.

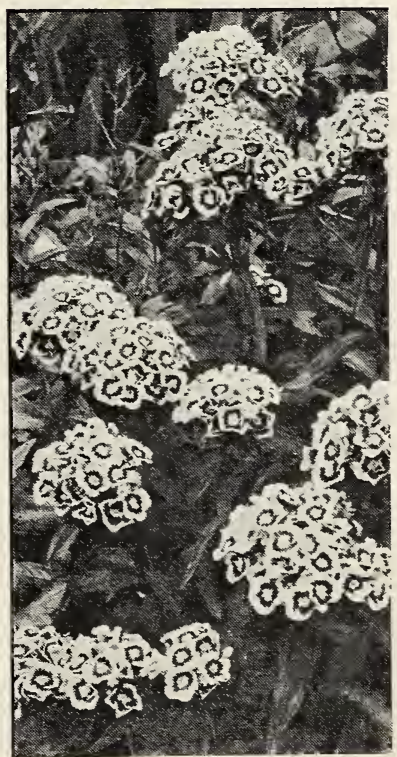

Annual Sweet William 

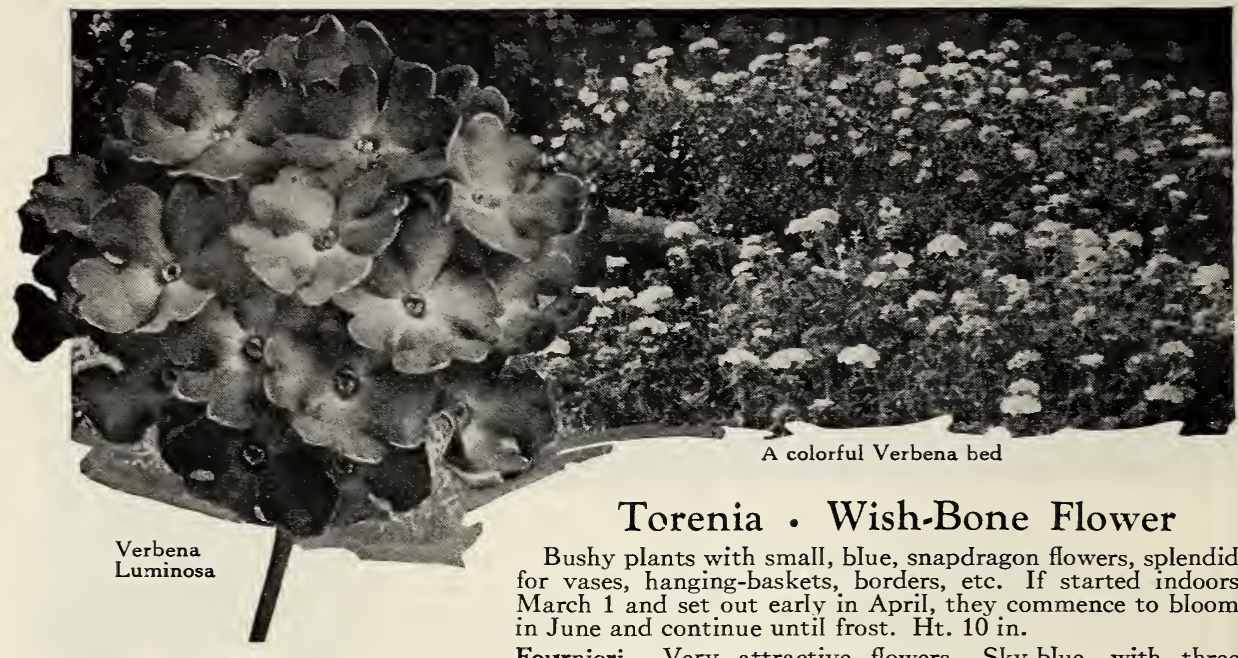

\section{Torenia - Wish-Bone Flower}

Bushy plants with small, blue, snapdragon flowers, splendid for vases, hanging-baskets, borders, etc. If started indoors March 1 and set out early in April, they commence to bloom in June and continue until frost. Ht. 10 in.

Torenias are rarely seen in gardens, but they are fine, quick-growing annuals suitable for solid bedding or edging, with flowers of rich pansy velvet. They come up year after year from selfsown seed. The blooms continue from June uniil cut down by the first hard frost.

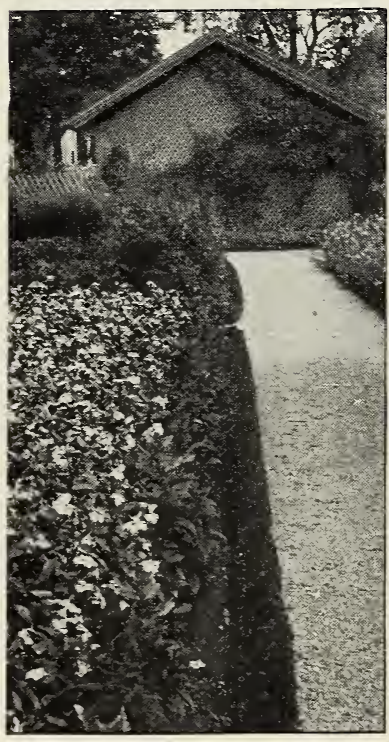

Fournieri. Very attractive flowers. Sky-blue, with three spots of dark blue and a bright yellow throat. Pkt. 25 cts.

\section{Verbenas}

Few flowers give greater satisfaction in the small home garden than the Verbenas of the bybrida group. They produce their large, fragrant clusters of blossoms constantly from midsummer until killing frost, in all kinds of weather and on even the poorest soils. These annuals make fine window-box plants and are splendid for low beds and borders. Sow the seed in May and thin the seedlings to stand 15 inches apart.

Large-flowering. The plants of this strain are quite compact and bear large blooms throughout a long season. We offer the following separate colors: Blue, Pink, Purple, Scarlet, White, and Mixed. Each, pkt. 15 cts.; $1 / 40 z$. 75 cts.

Royale. Enormous flower-heads, with individual florets measuring $11 / 4$ inches in diameter, distinguish this new strain from other Verbenas. The color is a rich deep royal blue with a Iarge creamy yellow eye. Its unusual size makes Royale particularly desirable. Pkt. 35 cts.; 3 pkts. $\$ 1$.

NEW GIANT HYBRIDS. A great improvement and bears immense trusses of flowers, with florets 1 inch across.

Etna. Bright geranium-red, with deep cream-colored eye. Luminosa. Brilliant flame-pink shading to salmon.

Purity. Glistening pure white flowers in very large trusses. Violet Star. Deep rich violet with white eye.

Mixed Colors. A mixture including all colors in this class. Each of above, pkt. 25 cts.; 5 pkts. $\$ 1$

Erinoides (Moss Verbena). This Iovely variety produces a carpet of moss foliage, above which are borne heads of purplish bue and white blooms in profusion from June until frost. For beds, baskets or rockeries. Pkt. 15 cts.

\section{Vinca - Madagascar Periwinkle}

The Vincas are favorites for bedding, as they do well in partly shaded as well as sunny locations, and do not require a rich soil. The plants are very handsome, about 1 foot high, with glossy dark green foliage and charming star-shaped flowers which will Iast in water for a week if cut when the buds are beginning to open. Start the seed indoors in January and set the plants outdoors in April, about 1 foot apart each way; they will bloom until fall. Make fine window-box plants. Give them a medium light soil and an occasional heavy watering. White or Rose. Each, pkt. 10 cts.; 1/4 oz. 60 cts. 

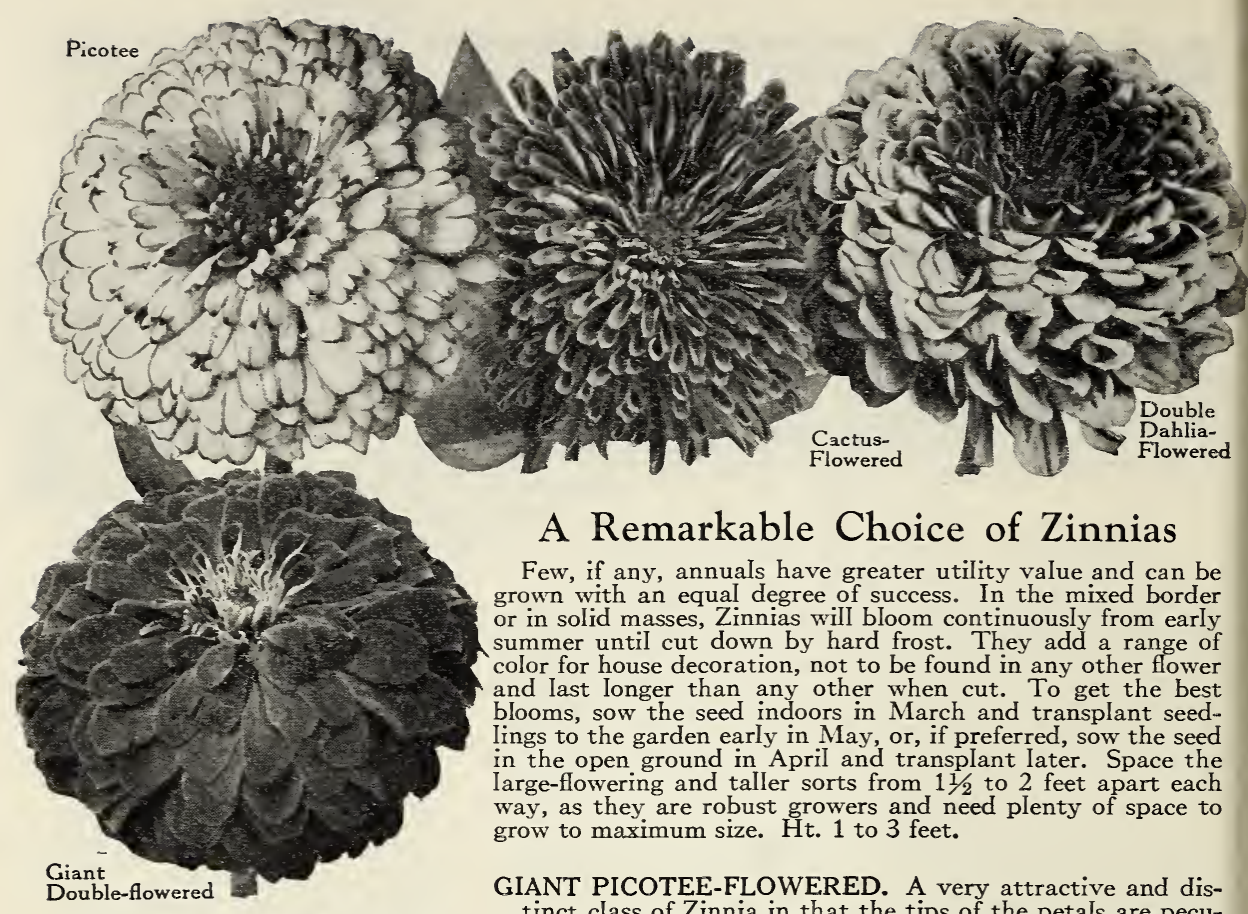

A Remarkable Choice of Zinnias

Few, if any, annuals have greater utility value and can be grown with an equal degree of success. In the mixed border or in solid masses, Zinnias will bloom continuously from early summer until cut down by hard frost. They add a range of color for house decoration, not to be found in any other flower and last longer than any other when cut. To get the best blooms, sow the seed indoors in March and transplant seedlings to the garden early in May, or, if preferred, sow the seed in the open ground in April and transplant later. Space the Iarge-flowering and taller sorts from $11 / 2$ to 2 feet apart each way, as they are robust growers and need plenty of space to grow to maximum size. Ht. 1 to 3 feet.

GIANT PICOTEE-FLOWERED. A very attractive and distinct class of Zinnia in that the tips of the petals are peculiarly marked with either a deeper shade or with another contrasting color. Mixed Colors, pkt. 25 cts.; $1 / 40 z$. $\$ 1$.

CACTUS-FLOWERED. Enormous flowers in a great variety of color with petals tubular at the base and partly opened at the tips. Pkt. 25 cts.; $1 / 4 \mathrm{oz}$. $\$ 1$.

GIANT DOUBLE-FLOWERED. A greatly improved Zinnia frequently reaching 5 to 6 inches in diameter on large, strong plants 2 feet high. In splendid separate colors: Scarlet, Salmon, Golden-Yellow, Rose, Crimson, White, Violet, Shrimp-Pink, and Mixed. Each, pkt. 15 cts.; $1 / 40 z$. 75 cts.

DWARF DOUBLE-FLOWERED. For borders or cutting, a foot high. White, Rose, Golden-Yellow, Purple, Crimson, Scarlet, and Mixed. Each, pkt. 10 cts.; $1 / 40 z$. 50 cts.

DOUBLE DAHLIA-FLOWERED. A beautiful new type closely resembling decorative dahlias in form and in the arrangement of the petals. They attain a height of 3 feet, producing large blooms of distinctive colorings as follows:

Canary Bird. Primrose.

Crimson Monarch. Red.

Dream. Purple.

Exquisite. Pale rose.

Golden State. Orange.

Mixed.

\section{Each, pkt. 25 cts.; $1 / 4$ oz. $\$ 1.50$}

LILLIPUT. This charming little Zinnia is used for borders and edgings but is very useful for cut-flowers because of its formal shape and keeping qualities. Ht. 8 to $10 \mathrm{in}$.

Salmon-Rose. The very smaII, globe-shaped flowers of this recently introduced variety are very double and resemble the Pompon Dahlia. The soft salmon-rose color is very pleasing. Pkt. 25 cts.; 5 pkts. \$1.

Mixed. An assortment of attractive colors. If the seed is started outdoors early, the blooms will begin in June and last until frost. Pkt. 20 cts. 


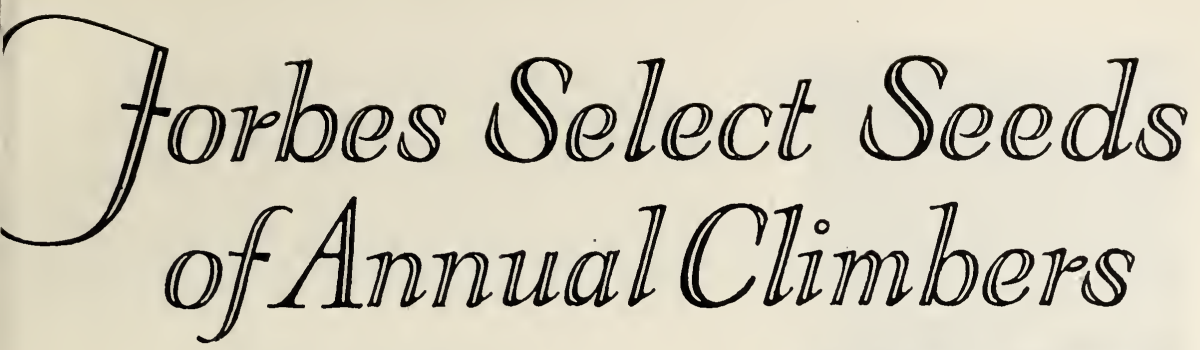

These fast-growing summer vines are mostly light in texture and may be planted freely. Vines give an added beauty to good architecture but should not obscure it entirely. Heavy vines, like the Moonflower and Gourd, have their use also when dense shade or a quick, temporary summer screen is needed.

Sow indoors in early spring, in flats of rich, light soil, placed in a warm window at $70^{\circ} \mathrm{F}$. Cover seeds with soil to a depth of four times their own size and press down firmly. Water with a fine spray and never allow soil ito dry out. In April or May, when danger from frost is past, transplant seedlings to the garden.

\section{Balloon Vine}

A rapid-growing vine that succeeds best in light soil and warm situations. The cross-shaped flowers are white; and the seed-vessels look like miniature balloons, $11 / 2$ inches across, with anemone-like leaves. Climbs 10 to 15 feet within six weeks. Pkt. 10 cts.; $1 / 4$ oz. 25 cts.

\section{Canary-Bird Vine}

This rapid-growing vine produces an abundance of pretty, fringed, bright yellow flowers, bearing a fancied resemblance to a bird with wings expanded. Finely cut light green foliage. Pkt. 10 cts.; $1 / 4$ oz. 25 cts.

\section{Cardinal Climber}

A brilliant and beautiful vine which grows 30 feet high, with fern-like foliage and cardinal-red flowers, $1 \frac{1}{2}$ inches across, borne in clusters profusely from midsummer until frost. Start seed indoors early, or sow in the open in late May. Splendid for trellises. Pkt. $15 \mathrm{cts}$; $1 / 4 \mathrm{oz}$. $50 \mathrm{cts}$.

\section{Cobaea - Cup-and-Saucer Vine}

This quick vine grows 25 to 30 feet during the season. It is valuable for covering trellises and arbors, and its tendrils cling to any rough surface. In sowing, place seeds edgewise and cover lightly. Sow indoors in March or outdoors in May. Scandens. Bell-shaped, purple flowers. Pkt. $10 \mathrm{cts}$; $1 / 4 \mathrm{oz}$. $35 \mathrm{cts}$.

Scandens alba. The white form. Pkt. 15 cts.; 1/4oz. 50 cts.

\section{Cypress Vine}

Popular vines with delicate fernlike foliage, and mass of beautifuI, smaII, star-shaped flowers. Soak seed in water for a few hours before planting to hasten germination. Frequently grows 15 feet and is fine for trellises. Sow outdoors in May. Scarlet, or White. Each, pkt. $10 \mathrm{cts}$.; $1 / 4 \mathrm{oz}$. 25 cts.

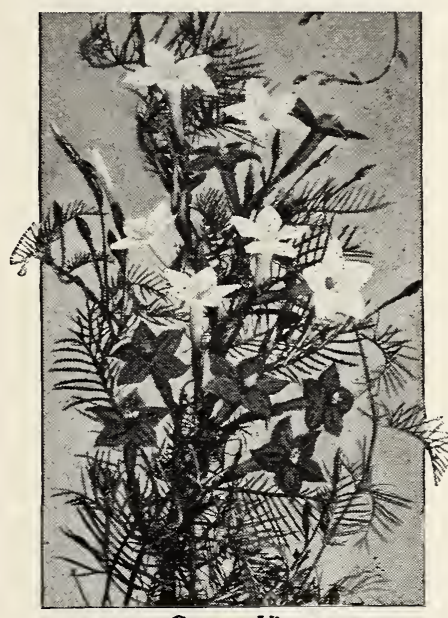

Cypress Vine

Most annual vines like deep, rich soil, Iots of water, plenty of warmth and sunlight.

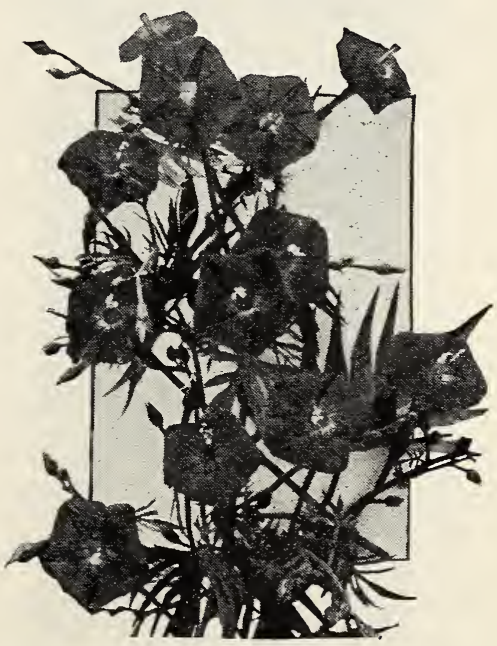

Cardinal Climber 


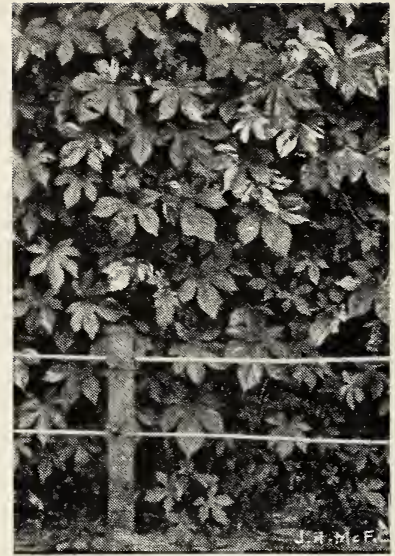

Humulus

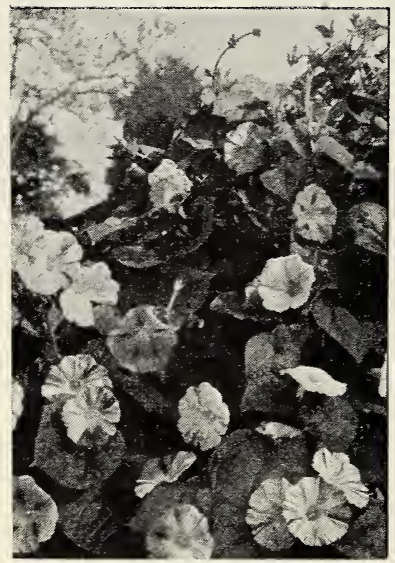

Japanese Morning-Glory

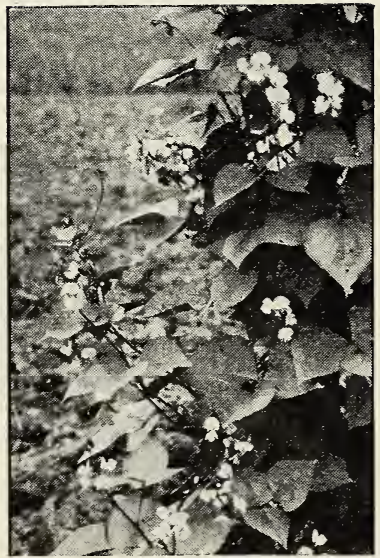

Dolichos, Daylight

\section{Dolichos - Hyacinth Bean}

A rapid-growing vine, bearing large, handsome foliage and bright flowers, followed by curious bean-shaped pods.

Darkness. Stems and under sides of foliage purplish red. The spikes of reddish purple, pea-like flowers are succeeded by showy seed-pods. Ht. 8 to $20 \mathrm{ft}$. Pkt. $10 \mathrm{cts}$; $0 z .50 \mathrm{cts}$.

Daylight. Covered from the ground up with erect racemes of pure white flowers. The flowers are followed by ornamental white seed-pods. Ht. 8 to $10 \mathrm{ft}$. Pkt. $10 \mathrm{cts}$; oz. $50 \mathrm{cts}$.

\section{Ornamental Gourds}

These tender annual vines produce different gourd fruits. Some sorts grow 40 feet long, quickly covering fence, arbor, or unsightliness with soft leaves and white, musk-scented flowers. Start inside and transplant to warm spot.

COLLECTION: One pkt. each of 12 named varieties, $50 \mathrm{cts}$.

Hercules' Club. Greenish white fruits, 2 to 6 feet long, shaped like a club and commonly grown like squash, in hills 2 to 3 feet apart each way, in warm, rich soil. Relished as an Italian vegetable. Pkt. 10 cts.; oz. 25 cts.

\section{Humulus · Japanese Hop}

This rapid summer climber which grows 20 to 30 feet, resembles the common hop, but, being an annual, attains fuII perfection the frrst season. The foliage is luxuriant and deeply cut, making a dense covering. It is one of the best plants for covering verandas and trellises, producing grateful shade, and is ornamental. Heat, drought, and insects do not trouble it.

Variegated. Foliage variegated with creamy white on deep green. If sown late in May, will reach, in four to six weeks, a height of 10 to $15 \mathrm{ft}$. Pkt. $10 \mathrm{cts}$; $1 / 4 \mathrm{oz}$. $25 \mathrm{cts}$.

\section{Ipomoea - Moonflower}

Climbers of rapid growth, with large, beautiful flowers. To cover walls, trellises, arbors, when supported, they are invaluable. It is well to soak the seed in warm water over night. Grandiflora alba (Giant White Moonflower). At night and during dull days the plants are covered with large, white, fragrant flowers, 5 to 6 inches in diameter. It grows very rapidly to a height of 20 feet, and will cover a Iarge surface. Start seed early indoors and transplant in May; or sow in open ground after soil is warm. Pkt. 10 cts.; oz. 75 cts.

\section{Momordica}

Curious climbing vine with ornamental foliage and golden warted fruit which opens, showing the seed and its brilliant carmine interior. For trellises and rockwork. Ht. 6 to $10 \mathrm{ft}$

Balsamina (BaIsam Apple). Has orange-colored, appleshaped fruit, and yellow flowers. Pkt. $10 \mathrm{cts}$; $1 / 20 z .50 \mathrm{cts}$. Charantia (Balsam Pear). Pear-shaped yellow fruit. Eaten as $L a-K w a$ by the American-Chinese. Pkt. $10 \mathrm{cts}$; $1 / 2 \mathrm{oz}$. $50 \mathrm{cts}$.

\section{Morning-Glory - Convolvulus}

One of the most free-flowering and rapidly growing plants for shading porches and covering screens. The foliage is a dark green, and the freshness and delicacy of the flowers fully make up for their fugitive character.

Baby or Heavenly Blue. Blue flowers measuring 4 to 5 inches across, make a beautiful show on arbors and trellises. Also used as a greenhouse climber. Pkt. 15 cts.; $1 / 2$ oz. 50 cts. Imperialis, Single Mixed (Japanese Morning-Glory). Of the easiest culture, can be sown in the open ground in a sunny situation when the weather has become warm. They soon cover a large area. The flowers are gigantic and their colorings range from snow-white to black-purple, with all the possible intermediate shades. Pkt. $10 \mathrm{cts}$.; $\mathrm{Oz} .50 \mathrm{cts}$. 


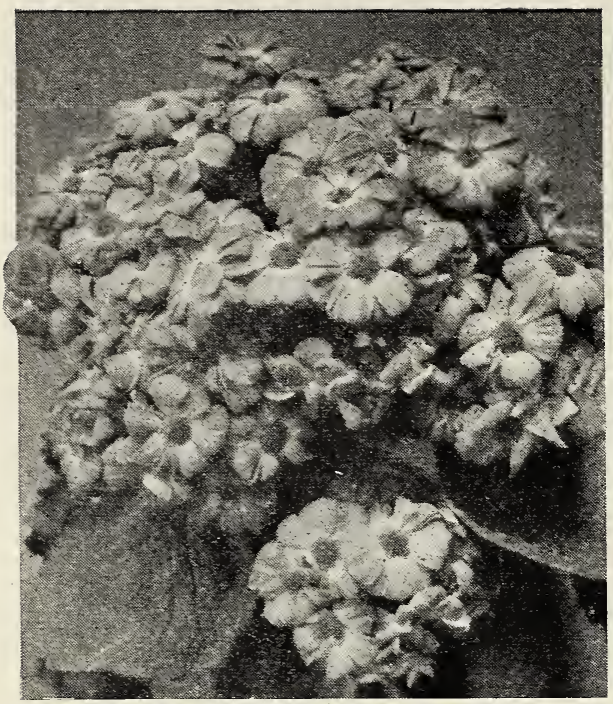

James and Wetherill's Prize Cinezaria

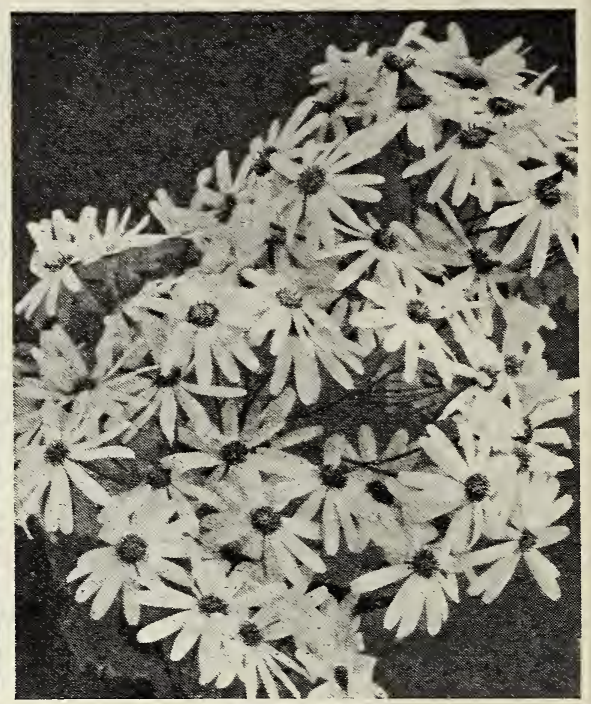

Cineraria stellata
The skill of the hybridizer has given us three very distinct types of Cineraria: those with Iarge flowers, like Forbes Giant-flowering $\mathrm{Hy}-$ brids; those with starry, rather smaII flowers produced in great abundance, like SteIIata; and the intermediate or hybrid types which stand between the others in size and profusion of bloom. They are splendid for early spring decoration in the conservatory. Stellata is fine for cutflowers.

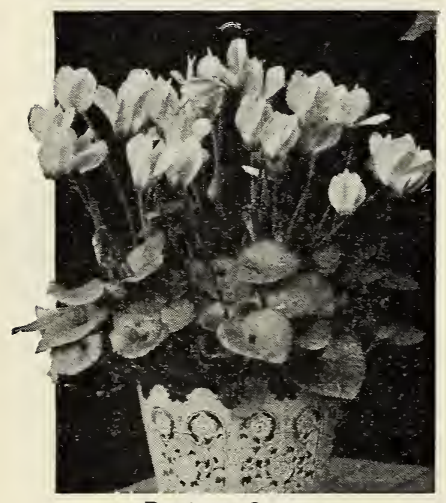

Persicum Cyclamen

\section{Cineraria}

Ornamental house-plants, bearing magnificent heads of velvety, daisy-like flowers, in white, pale blue, dark blue, violet, pink, carmine, and crimson, with many bicolors. Sow from May to September for a succession. Ht. $1 \frac{1}{2}$ to $21 / 2 \mathrm{ft}$. James and Wetherill's Prize Strain. This is the product of two Scotchmen famed for their excellent work in planthybridization. It is of dwarf habit with flowers of superb size. Pkt. 75 cts.; 3 pkts. $\$ 2$.

Forbes Giant-flowering Hybrids, Mixed. This is grown for us by a famous European specialist. The flowers are 3 inches in diameter, in white, rose, flesh, crimson, blue, violet, etc. The plants are robust and medium tall. Pkt. 50 cts.

Stellata (Star Cineraria). A charming variety, with large, spreading panicles of starry flowers in the same colors as the ordinary Cineraria. The extreme elegance of the plants and flowers make them wonderfully effective for house and conservatory; also useful for cutting. Ht. $21 / 2 \mathrm{ft}$. Pkt. $50 \mathrm{cts}$.

\section{Cyclamen}

Charming house-plants, with beautiful foliage and richly colored, fragrant flowers. Universal favorites for winter and spring blooming. Seed, sown any time during the spring or autumn, produces flowers in from twelve to eighteen months. The seed is fine and must be carefully handled. Sow in rows in flats of mellow, sandy soil. After a month, begin transplanting the seedlings to another flat, 1 inch apart in the row. This transplanting will continue for two months. Give a little shade, a lot of moisture, and plenty of air. Carry over winter in $21 \frac{2}{2}$-inch pots until late spring. Transplant to Iarger pots as plants develop. Cyclamen thrive if kept moist and in a warm, moist atmosphere.

Persicum, Mixed. A very frne strain, not so large but easier to grow than the Giant. Pkt. 25 cts.; 100 seeds $\$ 1.50$.

Giant Papilio or Butterfly. A beautifully fringed variety. Giant Pearl of Zehlendorf. Dark salmon blooms of Iarge size. Giant Rococo, Mixed. Large. fringed blooms and corolla. Giant Mrs. Buckston. Heavily fringed, edged salmon-pink. Giant Excelsior. Rich, deep red mammoth flowers. Giant Finest Mixed.

Each Giant, pkt. 75 cts.; 100 seeds $\$ 3.50$ 


\section{Dracaena . Dragon Plant}

Indivisa. Beautiful, ornamental-leaved plants from Australia. The long, narrow, green foliage makes them indispensable as center plants for vases and for house decorations. Easily grown from seed started at any time of year in a greenhouse. Pkt. 15 cts.; $1 / 2$ Oz. 75 cts.

\section{Geranium}

These grow readily from seed the first year and produce blooming plants the first summer. Should be started indoors early in February and transferred to the open in May or June. Ht. 1 to $2 \mathrm{ft}$.

Lady Washington (Odier). Large flowers, beautifully blotched. Pkt. 25 cts.; 5 pkts. \$1.

Pelargonium, Turner's English Hybrids. A very high-class strain for conservatory culture. The seed is saved from the finest hybrids and produces blooms of huge size and beautiful colorings. Pkt. 75 cts.; 3 for $\$ 2$.

Zonale, Mixed. A superb strain of the Iargest and finest varieties. Pkt. 25 cts.; 5 pkts. $\$ 1$.

Select Mixed. Saved from a collection of choice varieties. Pkt. 25 cts.; 5 pkts. $\$ 1$.

\section{Gerbera - Transvaal Daisy}

These half-hardy perennials are usually grown as greenhouse or window plants. The daisy-like blossoms, 2 to 4 inches across, borne on long stems, are unsurpassed as cut-flowers, as they are of wonderful lasting quality. To get best germination, plant the seeds obliquely with the downy end just above the soil surface. Start seed real early in flats of well-sanded soil. When potting up, also use a sandy soil. For garden culture in cold climates the plants are wintered over in coldframes like pansies, etc. They will commence flowering the frrst year, but old plants produce a greater abundance of bloom.

Jamesoni Hybrids. The flowers are borne on Iong, slender stems well above the foliage. The colors include a galaxy of unequaled delicacy and richness, from pure white through yellow, orange, salmon, rose, cerise, and ruby-red to violet. Pkt. 50 cts.; 3 pkts. $\$ 1.25$.

\section{Gloxinia}

Large-flowered Hybrids. Magnificent house-blooming plants with Iarge, brilliantly colored, tubular flowers of velvety texture, and handsome bronzy green foliage with white veins. Will bloom in six months from sowing. Compact and erect in growth, the plants are large-flowering and freeblooming. Start the seed in flats and transplant seedlings to pots. Keep soil moist at all times but avoid wetting the leaves. Pkt. 50 cts.

\section{Mignonette}

Forbes Special Forcing Strain. A remarkably Iarge-flowering strain, with exquisitely fragrant spikes 14 inches tall. For December flowering, sow the seed in August, in 21/2-inch pots. PIant five or six seeds in each pot and when still real small, remove all but two. Protect seedlings with cheese cloth. About October 1, cut off one plant and plant out on a bench, one foot apart, without disturbing plants. When 4 inches high, pinch back. For spring bloom, sow in January on bench and then set out Iater. Pkt. 75 cts.; 3 pkts. $\$ 2$.

\section{Mimosa - Sensitive Plant}

Pudica. A curious annual, the leaves of which instantly close up when touched. It is a neat ornamental plant for either pot or garden culture and is very interesting. Sow seed in a warm house in March and transplant to $21 / 2$-inch pots for bedding. A few can be shifted to larger pots for greenhouse display specimens. Ht. $11 / 2 \mathrm{ft}$. Pkt. $15 \mathrm{cts}$.

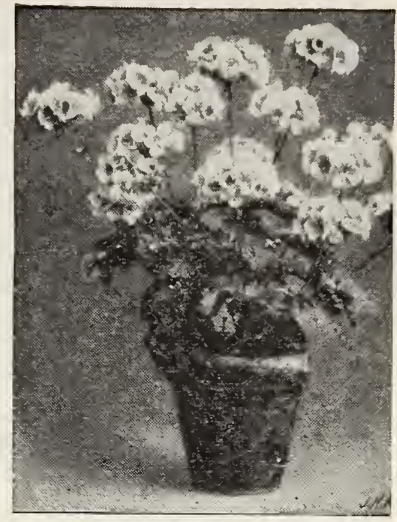

Lady Washington Geranium

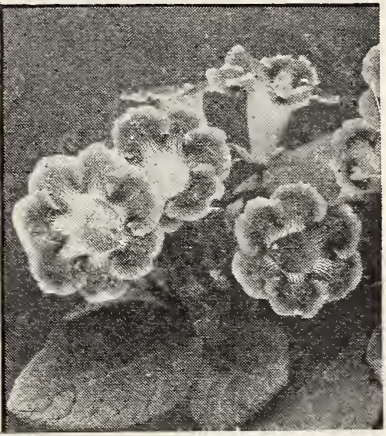

Gloxinia, Large-flowered Hybrids

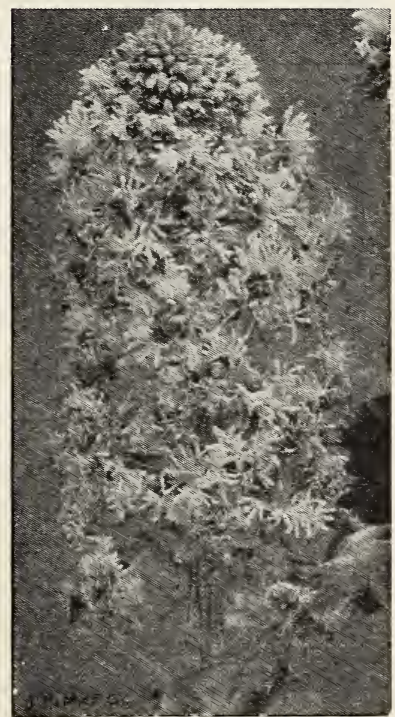

Forbes Forcing Mignonette 


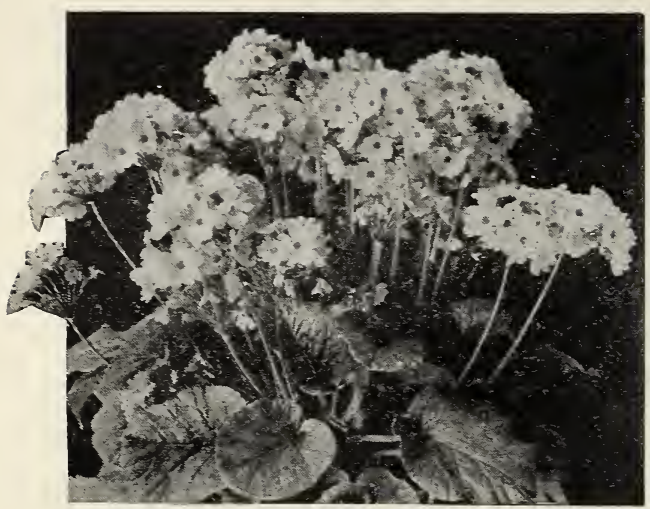

Primula obconica

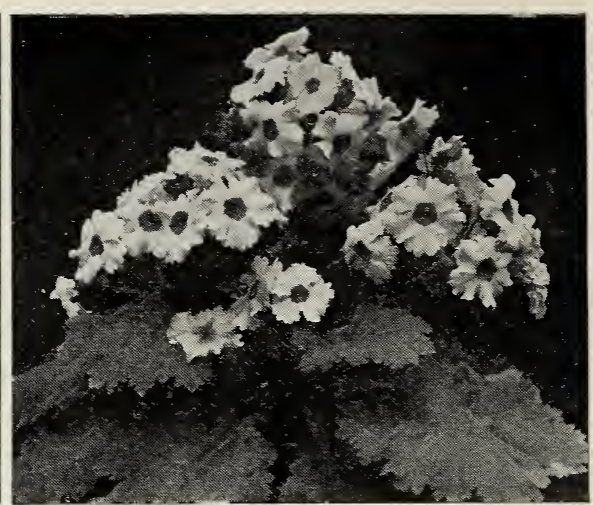

Giant Fringed Primula sinensis
Few plants for greenhouse use provide such charming variation of form and texture of flowers as the several species of Primulas offered here. Great strides have been made in recent years, in improving the vigor of the plants and size and abundance of bloom. They make unusually attractive house plants.

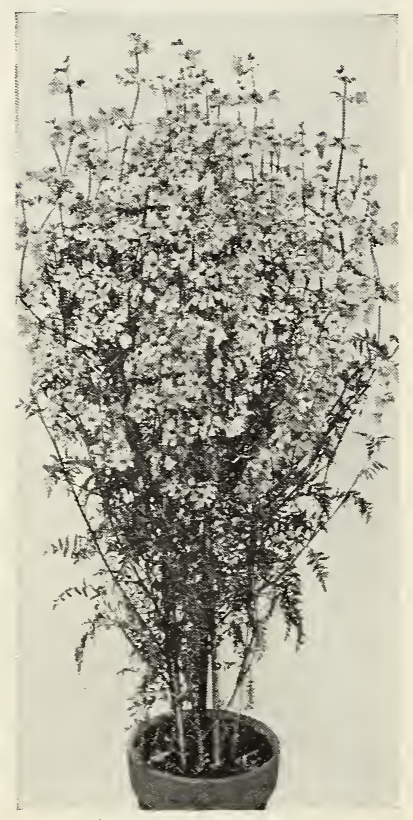

Schizanthus, Pink Pearl

\section{Primula Primrose}

The beautiful Chinese Fringed Primroses and Obconica varieties are excellent winter-blooming pot-plants. Use soil consisting of sand and leaf-mold worked through a fine sieve. Allow for drainage. Cover seeds lightly, water frequently, and give a temperature of 55 degrees. Shift the seedlings to larger pots as they develop, provide a moist atmosphere and ventilation and plenty of shade. For Christmas blooming sow seed in January and for Easter blooming about May 1.

\section{Primula malacoides}

The improved Baby Primrose. Foliage light green, deeply waved and fringed. Flowers in profusion on long stems. Lilac, White, or Rose. Each, pkt. 25 cts.; 5 pkts. \$1.

\section{Primula obconica}

These are of the easiest culture in greenhouse or home, flowering abundantly and continuously with little care, and should be sown during the spring in good porous loam.

Grandiflora gigantea, Mixed. Pkt. 25 cts.; 5 pkts. \$1.

\section{Primula sinensis}

This beautiful Chinese Fringed Primrose is indispensable for spring decoration in the home, and ranks as one of the finest of all winter-blooming pot-plants.

Giant Fringed ( $P$. sinensis fimbriata). Our Giant Fringed strain is of the highest merit. Ht. 10 in. White, Crimson, Blue, or Mixed. Each, pkt. 50 cts.; 5 pkts. \$2.

Stellata fimbriata, Mixed. A very pretty form with Iarge heads of star-shaped flowers of various colors. A splendid potplant. Ht. 10 in. Pkt. 50 cts.; 5 pkts. \$2.

\section{Schizanthus - Butterfly Flower}

The plants branch freely and form a neat bush 2 feet high, literally covered with butterfly blooms of such exquisite pale colorings as are found in orchids. Sow in hotbed in March and April and transplant seedlings. When 3 inches tall, pinch out top. Follow by sowings outdoors in May and June to keep up a succession. For December and January bloom, start seed September 1 and shift seedlings up to November 10 .

Wisetonensis, Pink Pearl. Large, delicate, light colored flowers, prettily blotched with pink, yellow, bronze, and light red. Pkt. 25 cts.; 5 pkts. \$1.

Wisetonensis Hybrids. These beautiful flowers range from white through pink, yellow, and carmine to purple. Pkt. 25 cts.; 5 pkts. \$1. 


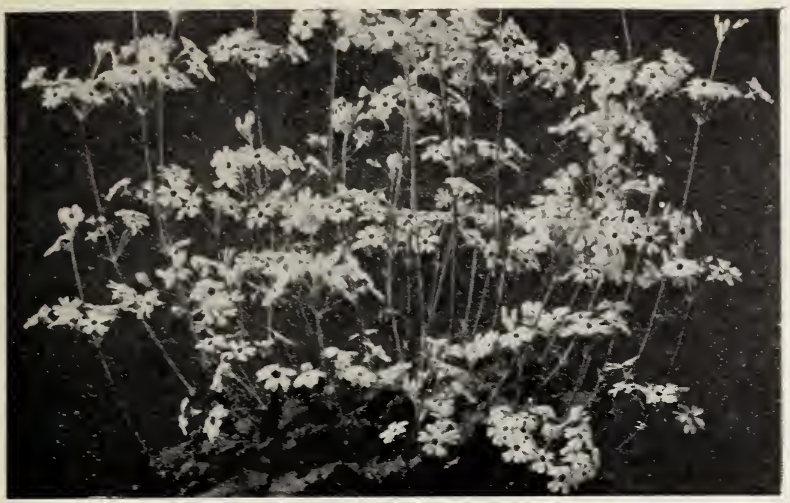

Primula malacoides

\section{Smilax}

Graceful climbers for greenhouse or conservatory. Foliage is indispensable for bouquets and decorations. Pkt. 25 cts.

\section{Solanum}

Fine for Christmas house-plants. This thrives best in light rich soil. Start seed in January and bring on it pots, either inside or in frames, during summer.

Capsicastrum nana (Jerusalem Cherry). Very usefuI and ornamental pot-plant for winter decoration. It is of dwarf, branching habit, bearing a profusion of bright scarlet, globular berries. Leaves oval, small. Ht. $1 \mathrm{ft}$. Pkt. $15 \mathrm{cts}$. Cleveland Cherry. The Ieaves are small and oval-shaped and the dwarf, branching plants bear the familiar, globe-shaped, bright red fruits. Ht. $1 \mathrm{ft}$. Pkt. 15 cts.

\section{Stevia}

Serrata. Free-blooming house-plants for summer or winter use, bearing a profusion of fragrant, waxy, white, starshaped flowers that are excellent for cutting. To get best results, grow in a cool house. Ht. $2 \mathrm{ft}$. Pkt. $15 \mathrm{cts}$.

\section{Stocks - Gilliflower}

Seed sown indoors in February, transplanted and set out in ApriI, will bloom August 1. For winter plants, sow seed in June, July, or August, transplant into $21 / 2$-inch pots, and bench ten weeks later. Keep plants 1 foot apart and at $50^{\circ} \mathrm{F}$.

Large-flowering Dwarf Ten-Weeks. The fastest-growing strain for successive cutting. Specially selected for double flowers. Ht. 15 in. Light Blue, Canary-Yellow, SalmonPink, Brilliant Rose, Flesh-Pink, Carmine, White, Purple, or Mixed. Each, pkt. 15 cts.; $1 / 8$ oz. 75 cts.

Improved Giant Perfection (Cut-and-Come-Again). A tall, giant-flowering strain of pyramidal growth. Ht. $2 \mathrm{ft}$. Silvery Lilac, Rose, Canary-Yellow, White, or Mixed. Each, pkt. 25 cts.; $1 / 8$ oz. $\$ 1$.

Giant-flowering Beauty. This strain is the finest for greenhouse culture. Beauty of Nice, delicate pink; Queen Alexandra, silvery lilac; Mont Blanc, pure white; Crimson King, dark crimson; Soleil de Nice, canary-yellow; Almond Blossorn, lovely pink. Each, pkt. 25 cts.; $1 / 80 z$. $\$ 1$.

\section{Verbena}

Lemon Verbena(Aloysia citriodora). Every garden should have plants of this fragrant favorite. Its pale green, delightfully scented foliage goes well with any flower. Pkt. $20 \mathrm{cts}$.

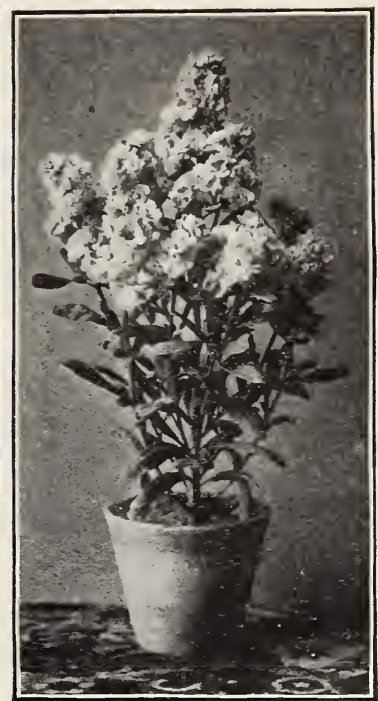

Giant-flowering Beauty Stocks

We do not half appreciate the real usefulness of the Stocks in this country. They are not, as a rule, successful out-of-doors here, but their splendid spikes of bloom, in almost every color of the rainbow, may easily be had in the greenhouse and conservatory. The fresh, delicious fragrance of the Gilliflowers is a splendid addition to their value as a cut-flower.

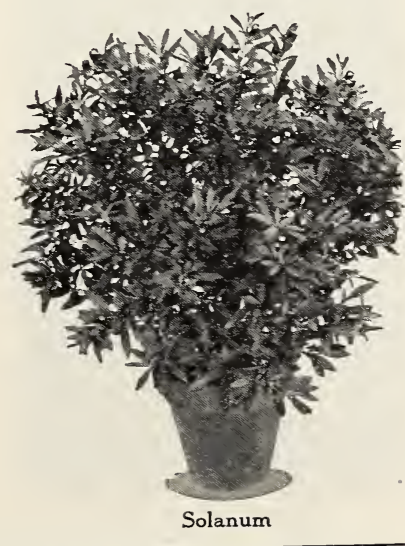




\section{Selected Strains of Annual Flower Seeds for Greenhouse Forcing}

These not only provide a means of utilizing otherwise wasted space in the greenhouse but also furnish beautiful cut-flowers and pot plants in a very short growing season.

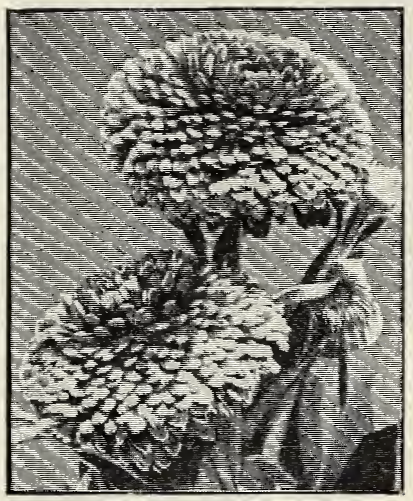

Calendula, The Ball

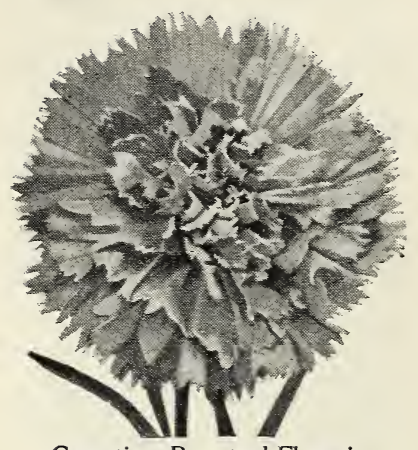

Carnation, Perpetual Flowering

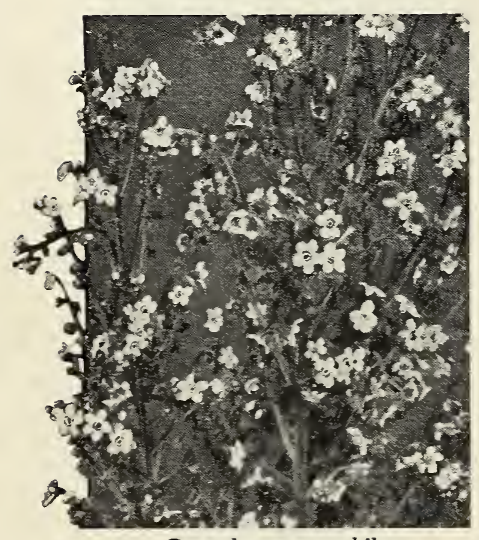

Cynoglossum amabile
BEGONIA. Seedlings raised in heat early in spring will flower profusely the same summer.

Single Tuberous-rooted, Mixed. Saved from finest exhibition varieties in many brilliant shades of color. Pkt. 50 cts.

Double Tuberous-rooted, Mixed. Producing very double flowers in brilliant rose and carmine, often mottled and margined with white. Pkt. 50 cts.

CALENDULA. These provide bright color and are very effective. The potted plants can be brought to bloom freely in winter and early spring.

Ball's Gold. A new, bright yellow strain with very full flowers. Pkt. 25 cts.; $1 / 4$ oz. \$1.

Campfire. An excellent, new, very large-flowering strain with brilliant orange flowers having a scarlet sheen and full yellow center. Pkt. 35 cts.; 3 pkts. $\$ 1$.

The Ball. Exceptionally Iarge, extra-double flowers of bright orange. Pkt. 25 cts.; $1 / 40 z .75$ cts.

CANDYTUFT. These charming flowers are showy and excellent for cutting.

Giant White Hyacinth-flowered or Improved Empress. A wonderfully improved, extra-choice strain, forming muchbranched plants 18 inches high, each branch ending in an immense spike of very large individual pure white flowers. Fine for cutting. Pkt. 10 cts.; 1/4oz. 50 cts.; oz. $\$ 1.50$.

CARNATION. The pleasing fragrance and rich colors make this indispensable for winter greenhouse culture.

Chabaud's Giant. The plants are strong and robust, carrying large flowers on long, stiff stems well suited for cutting. They usually come about 90 per cent double.

Jeane Dionis. White. Nero. A very rich crimson. Legion of Honor. Salmon-rose. Sparkler. Bright cardinal. Marie Chabaud. Yellow. The Pearl. Rose-pink.

Each, pkt. 25 cts.; $1 / 80 z$. $\$ 1$; one pkt. of each for $\$ 1.25$

Perpetual Flowering, Mixed. A leading English Carnation specialist has produced this everblooming strain and it is unusually fine for greenhouse culture. The seed is selected exclusively from plants which have been grown under glass. The plants will bear about 85 per cent double flowers of rare and delicate colors and color combinations. Pkt. $\$ 1$.

CENTAUREA. These bright blue flowers are borne over a long period and are quite excellent as cut-flowers.

Double Blue Emperor. An improved strain of the original old-fashioned Cornflower. The flowers are Iarger, very fuII, and of an intense blue. Pkt. 15 cts.; $1 / 40 z .50$ cts.

CLARKIA. The sprays of bright, attractive, smaII, double flowers are fine in masses and, when grown as pot plants, Clarkia is very effective.

Elegans, Double. Resembling Iong sprays of cherry blossoms, these come in unusually beautiful colors. We offer the following: Carmine Queen, Chamois Queen, Salmon Queen, Scarlet Queen, Vesuvius (orange-scarlet), White Queen, Purple Queen, and Mixed. Each, pkt. 15 cts.; $1 / 4$ oz. 50 cts.

CYNOGLOSSUM (Chinese Forget-me-not). An easily grown pot plant for late winter flowering. Sow in October and pot up right after Christmas, allowing 10 inches between plants.

Amabile, Blue. Delicately sweet scented, upright sprays of intense blue Forget-me-not-like flowers, much admired for their vivid color; an unusual one in flowers. Plants grow 18 to 24 inches high. Pkt. 25 cts.; $1 / 4 \mathrm{oz}$. $\$ 1$.

Amabile, White. A white strain of the above, making a nice contrast with the blue variety. Pkt. 25 cts.; $1 / 40 z$. \$1. 


\section{Selected Strains of Annual Flower Seeds for Greenhouse Forcing}

DIDISCUS cærulea (Blue Lace Flower). This is very attractive as a cut-flower when used with Sweet Peas, Freesias, or Lily-of-the-Valley. To flower in April, sow seeds in December in a $50^{\circ}$ house, transplant seedlings to small pots, and, four to frve weeks Iater, plant out on a bench, 4 inches apart, in rows 1 foot apart. The branching plants, 2 feet high, carry the beautiful, refined, light blue Iace-like flowers on good, long stems for cutting. Pkt. 25 cts.; $1 / 40 z$. $\$ 1$.

HELIOTROPE. This half-hardy perennial is very useful as a greenhouse plant. Its delightful fragrance makes it a most desirable bouquet flower, and it is easily grown from seed

Regale. A dwarf, giant-flowered strain with Iarge masses of bloom. Pkt. 35 cts.; 3 for $\$ 1$.

IMPATIENS. Not only an excellent pot plant, but unusually good as a garden plant for shaded locations. You can have fuII, bushy plants three months after sowing the seed.

Holsti. Bears brilliant cinnabar-red, waxy blooms continuously through summer and winter. The handsome flowers are $11 / 2$ inches across. Pkt. 25 cts.

Sultani Hybrids. The bright rosy scarlet blossoms, $11 / 2$ inches across, contrast nicely with the bright foliage. Pkt. 25 cts.

LANTANA. Still used for bedding purposes, but also makes an unusually attractive house plant, giving continuous bloom. Start the seed indoors early.

Dwarf Bedding Hybrids. The flowers are like miniature Verbena heads in orange, white, and rose shades. Pkt. $15 \mathrm{cts}$; $1 / 4 \mathrm{oz}$. $60 \mathrm{cts}$.

LARKSPUR. GracefuI flowers can be grown for late winter or Easter cutting from December-sown seed. Transplant seedlings to 4 inches apart in rows 18 inches apart.

Emperor Branching. These grow about 2 feet high and are of candelabra habit. Rose, Pink Delight, White, Blue, VioletPurple, or Mixed. Each, pkt. 25 cts.; 5 pkts. $\$ 1$.

MIMULUS. Interesting plants and useful for greenhouse or home decoration. Start seeds in February and grow on in a temperature of $55^{\circ} \mathrm{F}$.

Moschatus (Musk Plant). The trailing leaves are fragrant and the smaII, single yellow blossoms attractive. Pkt. 15 cts.

Tigrinus (Monkey Flower). Beautifully colored and spotted flowers like miniature Gloxinias. Pkt. 15 cts.

MORNING-GLORY. WeII-known climbers that are used to decorate the greenhouse. They grow rapidly from seed.

Baby or Heavenly Blue. A beautiful blue variety, with flowers 4 to 5 inches across. These make a striking mass of color. Pkt. 15 cts.; $1 / 2$ oz. 50 cts.

MYOSOTIS. The attractive little plants can be enjoyed through the winter if seed is started in March, plants set outdoors, and in fall potted and brought into the greenhouse.

Alpestris, Victoria. Of dwarf, compact growth, with sprays of bright flowers. Blue or Rose. Each, pkt. 15 cts.; 1/4oz. $\$ 1$.

NEMESIA. This will produce its beautifully colored small flowers in April if the seed is sown about January 15 in flats and transplanted Iater. Excellent for pot culture.

Strumosa, Sutton's Hybrids. The plants, 2 feet high, bear a profusion of flowers $1 / 2 \mathrm{inch}$ across, in white, yellow, rose, orange, and crimson, with numerous intermediate shades and various throat markings. Pkt. 25 cts.; 5 pkts. $\$ 1$.

PANSY, Forbes Big Beauties. These gigantic blooms, the largest of aII, come on strong, stocky, compact plants of exceptional vigor. The flowers, often 4 inches across, are perfectly formed, with very long, strong stems. The colorsbronze, silver, gold and copper, wine-red, pink, salmon, silver-grey, brown, beautifully blctched, mottled and bordered. Pkt. 75 cts.; $\frac{1}{16}$ Oz. $\$ 1.75$.

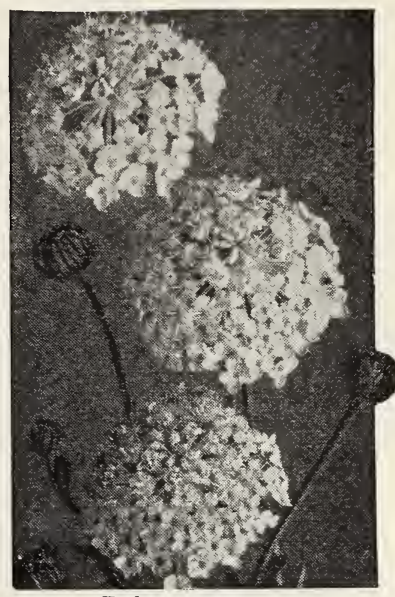

Didiscus cærulea

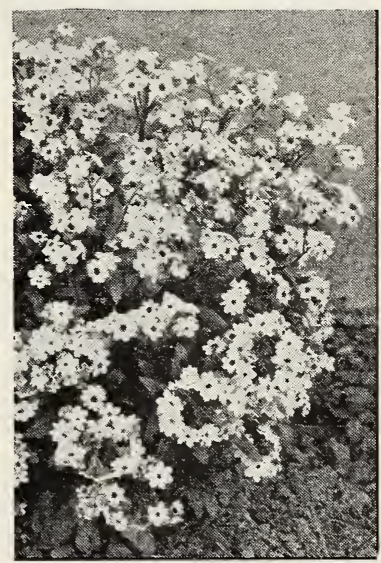

Myosotis alpestris

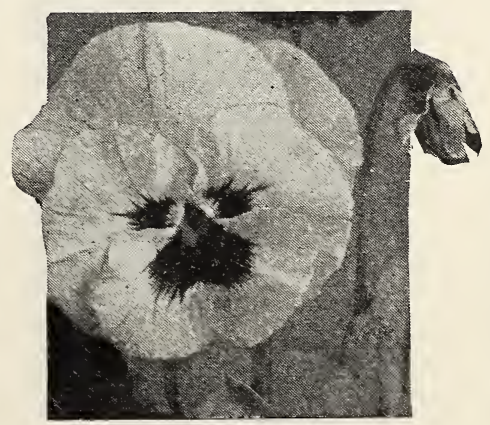

Pansy, Forbes Big Beauties 


\section{Selected Strains of Annual Flower Seeds for Greenhouse Forcing}

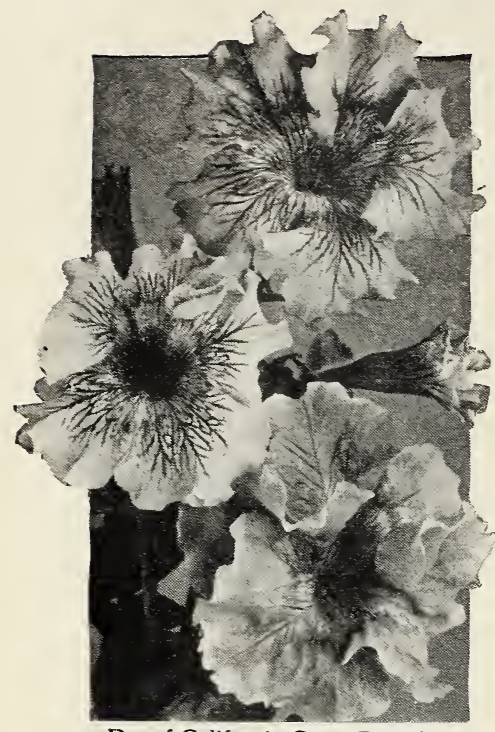

Dwarf California Giant Petunias

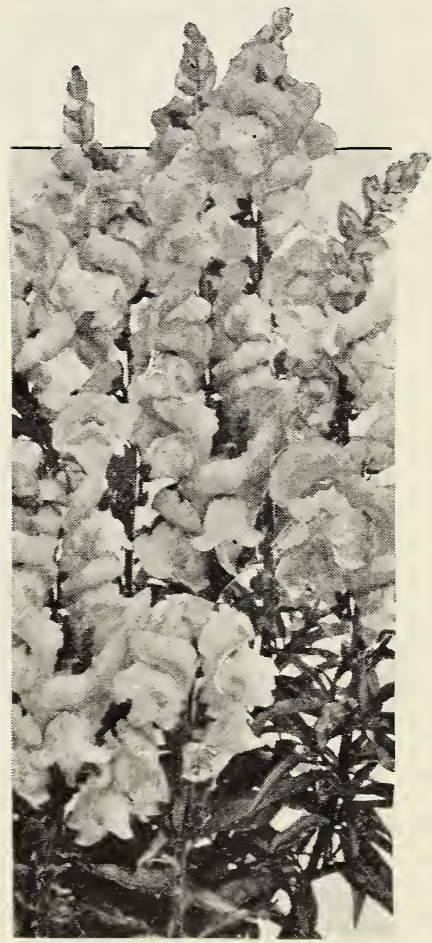

Forcing Snapdragons

PETUNIA. The individual beauty of these maminuch Petunias makes them highly desirable.

Dwarf California Giant. This is a wonderfully fine strain of single Petunia for pot-culture. It produces very dwarf, compact plants, only 4 inches high, covered with huge, fringed, single blooms, beautifully veined on self-colored grounds. Unquestionably the best single fringed strain for potting. Pkt. 75 cts.

SALPIGLOSSIS. These beautifuI, showy flowers are exceptionally fine for cutting, particularly in combination with Annual Baby's Breath. Easily grown from seed in a sunny location and blooms very freely.

Candelabra. Plants have a center stem with side branches full of large, Petunia-like flowers. Offered in six colors: Blue and Gold, Crimson and Gold, Golden Yellow, Chamois, Violet and Gold, Scarlet and Gold.

Each, pkt. 25 cts.; all 6 for $\$ 1.25$

SNAPDRAGONS FOR FORCING. These are special greenhouse strains with erect flower-spikes on strong stems, blooming in four to five months from seed.

Geneva Pink. DelightfuI glistening rose-pink, with closely set Iarge spikes.

Golden King. An improved golden yellow; fine for forcing.

Jennie Schneider. Rich glowing pink of the color of the well-known Columbia rose.

OrIando. Beautiful rich shade of bronze.

Penn-Orange. Vivid tangerine-orange. A striking variety of vigorous, upright growth.

Philadelphia Pink. The finest pure pink on a strong stem. White Rock. An extra-early-blooming pure white.

\section{Each, pkt. $\$ 1$; all 7 for $\$ 6$}

SWEET PEAS, Early-flowering Giant Spencers. These unusually beautiful varieties have been specially selected for greenhouse culture. If started in August, they will bloom in aII their glory from Christmas on.

Aviator. A very dazzling crimson-scarlet. Pkt. 25 cts.; oz. \$1.

Burpee's Orange. Clear orange. Pkt. 35 cts.; oz. \$2.50.

Giant Rose. Rich, deep rose-pink. Pkt. 35 cts.; oz. \$2.50.

Gilda Gray. SaImon-cerise over pink. Pkt. 35 cts.; oz. \$2.50.

Grenadier. Bright dazzling scarlet. Pkt. 25 cts.; oz. \$1.50.

Harmony. Clear bright lavender. Pkt. 25 cts.; oz. \$1.

Jeanne Mamitsch. Bright, rich pink. Pkt. 25 cts.; oz. \$1.

Mrs. Kerr. Clear saImon. Pkt. 25 cts.; oz. \$1.50.

Orange King. Rich deep orange. Pkt. 35 cts.; oz. \$2.50.

Snowstorm Improved. Best white. Pkt. 25 cts.; oz. $\$ 1$.

True Blue. Rich, clear blue. Pkt. 25 cts.; oz. \$1.

White Harmony. Pure white. Pkt. 35 cts.; oz. \$2.50.

Zvolanek's Rose. Deep pink. Pkt. 25 cts.; oz. \$1.50.

Forbes Early-flowering Mixed. A Iarge variety of color. Pkt. 15 cts.; oz. 75 cts.; $1 / 4$ Ib. $\$ 2.50$; Ib. \$9.

WALLFLOWER. These delightfully fragrant flowers are most enjoyed in Iate winter or early spring. Start seed in April, transplant seedlings to open ground, and in October pot up in 6-inch pots. Hold these in coldframe until February, when plants can be kept at $50^{\circ} \mathrm{F}$. and will give good bloom by March.

Early Paris Market. Ranging from yellow to brown, some tinged with red and purple. Pkt. $15 \mathrm{cts}$; $1 / 4 \mathrm{oz} .75 \mathrm{cts}$.

Hamlet. (New.) This fine variety, the result of a cross between Goliath and Aurora, forms a compact plant with unusually bright golden orange flowers. At the Chelsea Show it caused much favorable comment. Pkt. 50 cts.

New Double-flowering Early Wonder. This new strain produces exceptionally handsome flowers and is offered in separate colors: Canary-Yellow, Golden Yellow, and Brown. Each, pkt. 50 cts. 


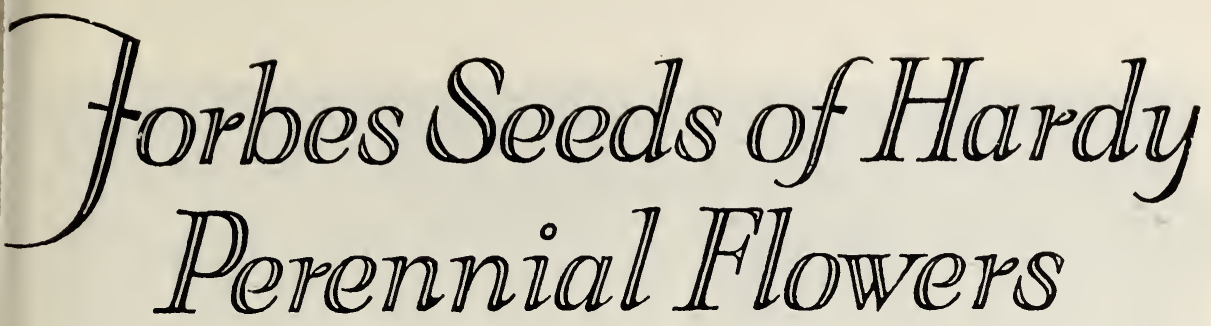

Perennial flowers are best used to form hardy borders, using low facers in front and tall plants at the back with intermediates between. To prevent the whole border from crowding and disorder, cut off the dead flowers before they go to seed. Against heavy rains and winds, they should be supported or staked and tied loosely. Adjusto ring stakes are good for certain types and tall Dahlia stakes for others; various lengths are needed for plants of different heights so that stakes are not conspicuous. A light mulch of leaves and manure is beneficial in fall.

To have large plants, perennial seeds are best sown in May, June, and JuIy, unless otherwise noted. Forget-me-nots, English Daisies, HoIlyhocks, Sweet William, and Pansies are best sown in August, in order to have plants not too large for handling. Large seeds should be sown in rows in flats or coldframes and lightly covered with sand or fine soil to the depth of twice their diameter. Cover fine seeds with a piece of burlap but no soil. Shade on a sunny day and transplant when two leaves occur, 3 to 5 inches apart. In some cases seedlings cannot be safely transplanted but in these cases thinning must be done until plants are separated. No ventilation, too much shade, and crowding cause "damping off," a disease very destructive to young seedlings. This can be prevented by using Semesan. When watering, apply thoroughly but with a fine spray.

\section{Achillea - Yarrow}

Ptarmica, The Pearl. Bears a profusion of small, double white florets during the entire season. Easily grown in welldrained garden soil, preferably a space open to the sunlight. Will flower the first season if sown early. Fine for cutting. Ht. $21 / 2$ ft. Pkt. 25 cts.; $\frac{1}{16}$ oz. $\$ 1$.

Millefolium rubra. A beautiful, velvety, deep pink variety. Ht. $31 \frac{1}{2}$ ft. Pkt. 25 cts.; $\frac{1}{16} 0 z$. $\$ 1$.

\section{Aconitum - Monkshood}

Napellus. Showy panicles of helmet-shaped, lovely, dark blue flowers and handsome foliage. It is very fine for borders and particularly where masses of blue color are wanted. If sown early, will usually bloom the first year. Thrives in shady places. Ht. $3 \mathrm{ft}$. Pkt. $15 \mathrm{cts}$.; $1 / 8$ oz. $75 \mathrm{cts}$.

\section{Adonis}

Aleppica (Syrian Floss). This is a hardy biennial with shining, blood-red flowers of exceeding brilliance. They are famed for their lasting qualities and are nicely set off by the vivid green, feathery foliage. The plants, 16 to 20 inches high, are valuable for bedding or borders. It will bloom the first year from seed started in February or March, or the seed can be sown outdoors in April. Pkt. 50 cts.

\section{Agrostemma - Rose Campion}

Coronaria (Mullein Pink). An attractive, free-flowering plant with silvery white leaves and glowing crimson flowers, borne on long, slender stems, fine for cutting. Blooms the first season if sown early. Ht. 2 ft. Pkt. 15 cts.; $1 / 40 z$. 50 cts. Coronaria alba. A white variety. Pkt. 15 cts.; 1/40z. 50 cts.

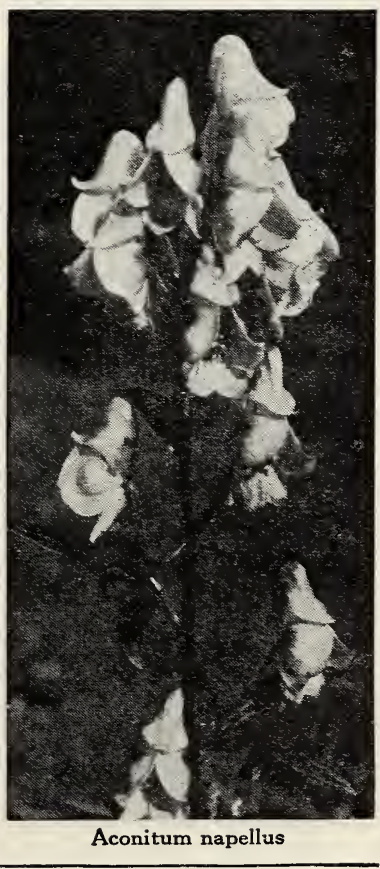



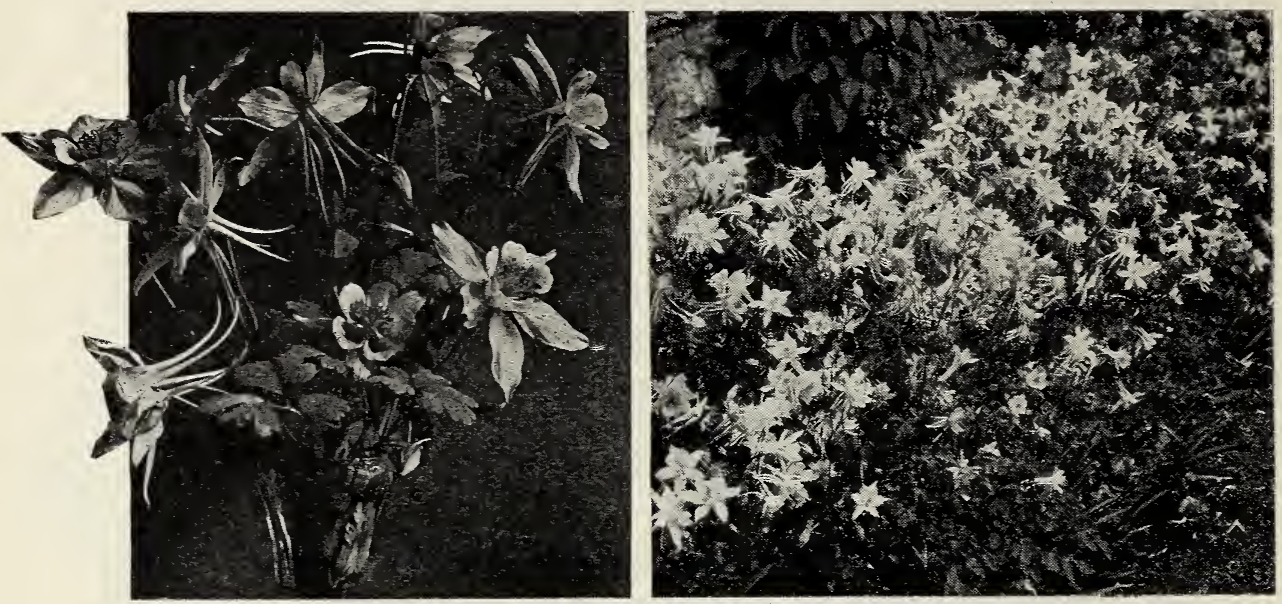

Aquilegia cærulea, Mrs. Scott Elliott's Long-spurred Hybrids

Alyssum saxatile compactum is one of the most valuable plants for the rockery where it should be used in liberal masses.

The Aquilegias include AIpina and Cærulea, excellent for rock-gardens, and others particularly fine for the perennial border.

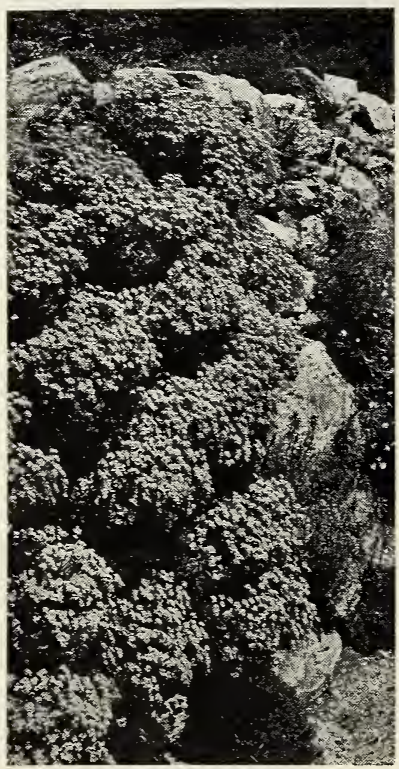

Alyssum saxatile

\section{Alyssum - Rock Madwort}

Saxatile compactum (Basket of Gold). A pretty perennial Alyssum for rock-gardens and borders. The plants have grey foliage and produce masses of bright yellow flowers in early spring. Ht. $1 \mathrm{ft}$. Pkt. $15 \mathrm{cts}$.; $1 / 4 \mathrm{Oz} .75 \mathrm{cts}$.

For other varieties see Annual List.

\section{Aquilegia - Columbine}

The hardy Columbines are among the earliest flowering perennials. They are easily grown, thriving in comparatively poor soil and in partial shade, and are general favorites for border planting. Many of the seedlings vary from type but all are beautifuI. The long-spurred type gives elegant cut-flowers. If sown in summer, plants will be ready by autumn for transplanting to the border to flower the next spring. Ht. 1 to $3 \mathrm{ft}$. Alpina. A very rare variety with powdery blue blooms in May or June. Good for the rock-garden. Ht. $1 \mathrm{ft}$. Pkt. $15 \mathrm{cts}$. Cærulea, Mrs. Scott Elliott's Strain of Long-spurred Hybrids. Allowed by the Royal Horticultural Society to be the best strain ever raised and has received awards at every exhibition where shown. The blooms are large, with very long spurs and range in color through shades of lavender, mauve, blue, purple, cream, yellow, pink, and red, making beautiful group harmonies. Ht. $3 \mathrm{ft}$. Pkt. $50 \mathrm{cts}$.

Cærulea (Improved Rocky Mountain Columbine). Pale, blue and white flowers. Ht. 2 ft. Pkt. $25 \mathrm{cts}$.; $1 / 8 \mathrm{cz}$. $75 \mathrm{cts}$. Cærulea, Rose Queen. Rose shaded with white. Ht. $21 / 2 \mathrm{ft}$. Pkt. 25 cts.; $\frac{1}{16} \mathrm{Oz} . \$ 1$.

Chrysantha, Single. Golden yellow. Ht. 3 ft. Pkt. 25 cts.; $1 / 8$ oz. 75 cts.

Copper Queen. The petals of this long-spurred variety are of a decided coppery hue. The corolla opens buff and slowly fades to a pure white. Pkt. 50 cts.

Edelweiss. This wonderful variety, growing 16 to 20 inches high, is covered with pure snow-white blooms. Because of its earliness and free-flowering tendency, it should have a place in every perennial border. Pkt. 50 cts.

Glandulosa vera. Large blooms of true, bright sky-blue, the outer corolla of which is white, while the bell is blue outside and blue sharply edged with white inside. This handsome Columbine, with curled spurs, blooms from April to June. Ht. $3 \mathrm{ft}$. Pkt. 50 cts.; 5 pkts. $\$ 2$.

Single Mixed. AII colors. Ht. $2 \mathrm{ft}$. Pkt. $10 \mathrm{cts}$; $1 / 4 \mathrm{oz} .50 \mathrm{cts}$. Double Mixed. AII colors. Ht. 2 ft. Pkt. $10 \mathrm{cts}$; $1 / 4 \mathrm{oz}$. 50 cts. 


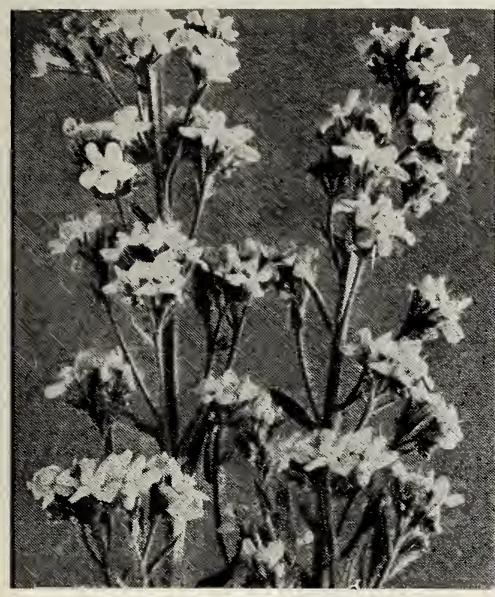

Anchusa italica, Dropmore

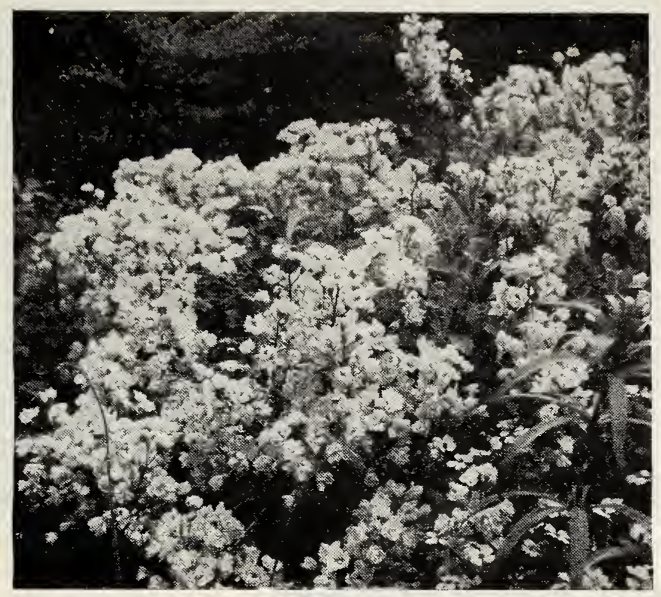

Arabis alpina

\section{Anchusa - Alkanet}

Italica, Dropmore. The tall, downy, green-foliaged plants bear forget-me-not-like flowers of pale violet-blue from June until September if not allowed to seed. Ht. $41 / 2 \mathrm{ft}$. Pkt. 15 cts.; $1 / 8 \mathrm{oz} .50$ cts.

For Ancbusa capensis see Annual List.

\section{Anemone - Pasque Flower}

Pulsatilla. A very pleasing perennial with finely cut, greygreen foliage. The blue and lilac flowers, 2 inches in diameter, are held erect on hairy stems during April and May. Excellent for rockeries and thrives in chalky soil. Sow outdoors in spring and shade during early growth. Does weIl in sunny location after established. Ht. $1 \mathrm{ft}$. Pkt. $25 \mathrm{cts}$.

\section{Arabis - Rock Cress}

Alpina. Plants especially adapted for edging and rockery. They form a dense carpet completely covered with pure white blossoms in May. Ht. 6 in. Pkt. 10 cts.; 1/4oz. 50 cts.

\section{Arenaria - Sandwort}

Montana. Dwarf, trailing vine suitable for rockeries, forming a dense carpet of foliage covered with small, white, starry flowers in May and June. Ht. 4 to 6 in. Pkt. 25 cts.

\section{Armeria - Thrift}

Laucheana. SmalI pompons of rose-crimson, borne from June to August, on stems above a tuft of grass-like leaves. Fine for edgings and rockeries. Ht. 6 in. Pkt. 25 cts.

\section{Aubrietia - False Wäll Cress}

Pretty, dwarf-growing rock plants with masses of silvery green foliage and sheets of flowers in spring and early summer. Deltoidea græca. Low, carpet-like plants covered in April and May with large, dark violet flowers. Ht. 6 in. Pkt. 25 cts. Deltoidea Moerheimi. Similar to $A$. deltoidea græca but with rose-colored flowers. Ht. 6 in. Pkt. 50 cts.

Large-flowering Hybrids. Perpetual bloomers like alyssum in growth. The flower-sprays come in crimson, purple, blue, pink and lilac, with evergreen foliage. Pkt. 25 cts.
AII varieties described on this page, except Anchusa, are ideal for the rockery. Arabis and Aubrietia are indispensable. Arenaria is rather uncommon but beautiful and enduring. The Pasque Flower is strikingly lovely in a rough rock setting.

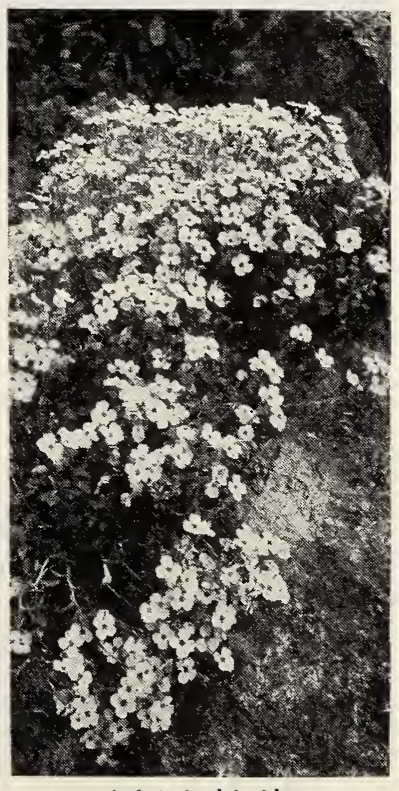

Aubrietia deltoidea 


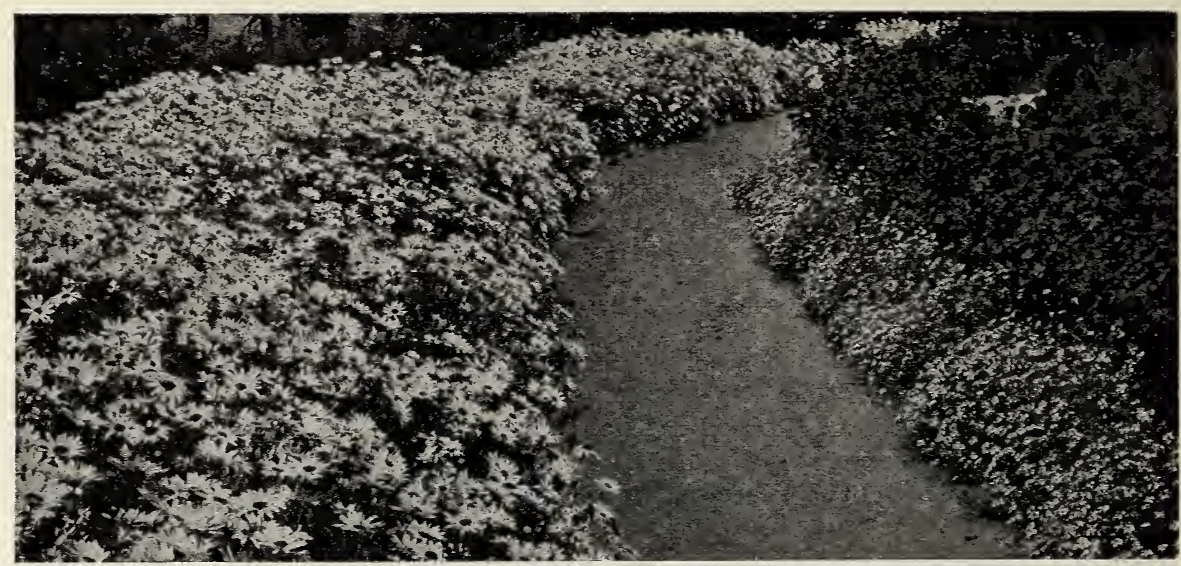

Border of Michaelmas Daisies

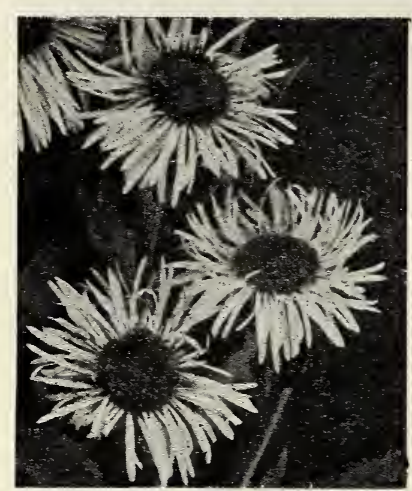

Aster Farreri

The Hardy Candytufts are extremely useful in the rockgarden, providing sheets of bloom in spring and fine dark foliage the rest of the season.

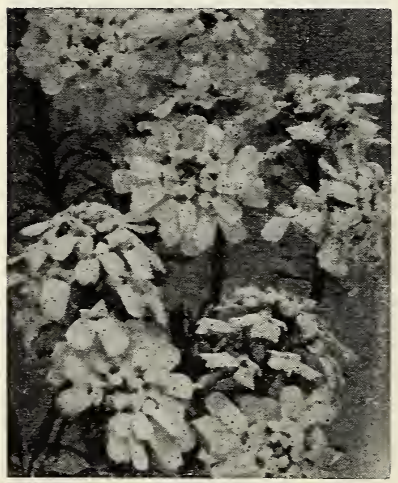

Candytuft, Sempervirens

\section{Aster}

Single-flowering, hardy herbaceous plants thriving in any good garden soil. These flower the second year from sced, and include the best of the American wild sorts.

Alpinus (Blue Mountain Daisy). Compact plants with bluelavender, daisy-like flowers from June to September. Ht. 5 to 10 in. Pkt. 25 cts.

Farreri. The delightful flowers, from $2 \frac{1}{2}$ to 3 inches across, are borne twenty to thirty on each plant, on Iong stiff stems. They glorify the garden from late April through June. The beauty of the flower, the ray petals of which are a lovely soft tone of violet-mauve, is greatly enhanced by a large golden orange disc. Ht. $2 \mathrm{ft}$. Pkt. 50 cts.; 5 pkts. \$2.

Michaelmas Daisies, Mixed (Star Wort). Attractive shades saved from a splendid collection. Ht. $1 \mathrm{ft}$. Pkt. $15 \mathrm{cts}$.

Subcæruleus. Bright mauve flowers in June and July. Does well in a sunny location. Ht. $1 \mathrm{ft}$. Pkt. $25 \mathrm{cts}$.

\section{Bellis Perennis - English Daisy}

Charming perennial flowers for spring bedding purposes. Sow in light soil in early spring and prick out, or sow in August and grow in a coldframe until spring, then transplant outdoors. Prefers a partially shaded position. Ht. 5 to 6 in.

Monstrosa maxima Varieties. Very double and borne on Iong and rigid stems. Giant Rose, Giant White, and Giant Mixed. Each, pkt. 25 cts.; 1/80z. \$1.50.

\section{Boltonia - False Chamomile}

Showy native hardy perennial, with finely petaled daisylike flowers, from July to September. Excellent for backgrounds as it grows 4 to 6 feet high but requires staking.

Asteroides. Small white aster-like flowers in great profusion, valuable for cutting. Pkt. $15 \mathrm{cts}$.

Latisquama. Blue-lavender flowers of unusual beauty. Fine for mixing through bouquets of larger flowers. Pkt. $15 \mathrm{cts}$.

\section{Candytuft - Iberis}

Hardy evergreen plants, making a magnificent showing the second year from seed. They cushion rock ledges, borders, etc., with banks of bloom. Sow outdoors in spring or fall in any sunny place. Ht. 6 to $10 \mathrm{in}$.

Sempervirens. Profuse, white bloorns from April to June, much used for rockeries, etc. Pkt. 25 cts.; $1 / 40 z$. $\$ 1$.

Gibral tarica. Lavender-pink flowers, shading white; very frne blooms in June and July. Pkt. 15 cts.; $1 / 40 z$. 75 cts. 


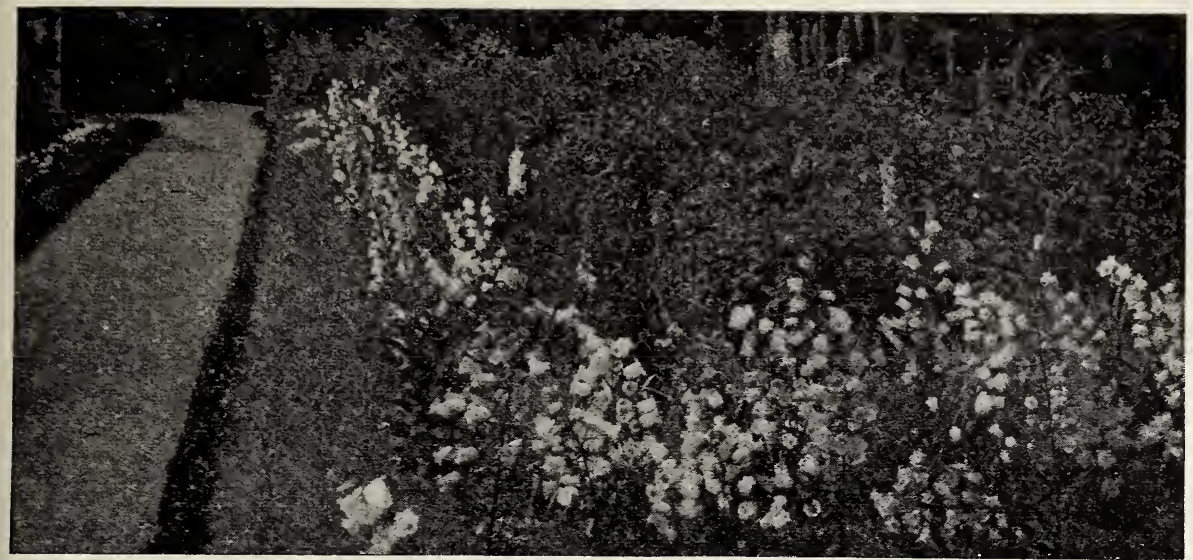

A border of Campanula Medium

\section{Campanula}

A large, beautiful, and most important family for the flowergarden. The dwarf species are charming for rock-gardens, and not difficult to cultivate. The tall varieties are very striking, ranging from 2 to 5 feet in height, but most effective when planted in a mixed border with early phloxes.

\section{Biennial Varieties}

Sow these hardy biennials in summer and transplant to a bed in autumn for flowering the following year. They make effective pot plants for spring flowering, if sown in summer, potted in autumn, and kept in a cool frame through winter. Medium, Single (Canterbury Bells). Large, bell-shaped flowers in many shades. A small proportion of the seedlings will always vary from color. $\mathrm{Ht}$. $2 \mathrm{ft}$. Blue, White, Rose, or Mixed. Each, pkt. $10 \mathrm{cts}$.; 1/4 oz. 50 cts.

Medium calycanthema (Cup-and-Saucer Canterbury Bells). This is the finest type of this old-fashioned and much-prized garden plant. Ht. 2 ft. Blue, White, Rose, or Mixed. Each, pkt. 15 cts.; $1 / 8$ oz. 50 cts.

\section{Perennial Varieties}

Bears a great profusion of attractive bell-shaped flowers; thriving best in light, rich soil.

Carpatica, Blue (Carpathian HarebeII). Free-flowering hardy plants, continuing in bloom the whole season; color clear blue. Good for edging and rock-gardens. Will bloom the first season if sown early. Ht. 6 in. Pkt. 15 cts.; $1 / 4$ oz. 75 cts. Carpatica alba. The white-flowered form of the above. Pkt. 15 cts.; $1 / 4$ oz. 75 cts.

Persicifolia (Peach Bells). Large, cup-shaped single flowers with long, slender leaves. Hardy but fine for pot plants. Ht. $2 \mathrm{ft}$. Blue or White. Each, pkt. $25 \mathrm{cts}$; $1 / 8 \mathrm{oz}$. $\$ 1$.

Pyramidalis (Chimney Bellflower). Beautiful stately plants for garden culture, with large, tubular flowers. Ht. $5 \mathrm{ft}$. Blue or White. Each, pkt. 15 cts.; $1 / 40 z .75$ cts.

\section{Carnations}

These will live over winter and flower again next season by giving slight protection with leaves or straw. For giantflowered annual varieties see Annual List.

Early Dwarf Vienna, Double Mixed. A fine variety for edging. Excellent for cutting. Ht. $1 \mathrm{ft}$. Pkt. $15 \mathrm{cts}$.; $1 / 4 \mathrm{oz} .75 \mathrm{cts}$.

Grenadin, or Hardy Border Carnations. Fine double Carnations for outdoor culture, flowering the second season. Pkt. 25 cts.; $1 / 4$ oz. $\$ 1$.

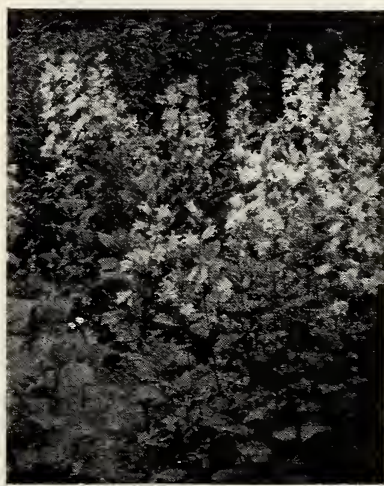

Campanula pyramidalis

The Campanula family is rich in rockery plants, especially those low, trailing species of the Carpatica type. Mix the white and blue varieties together.

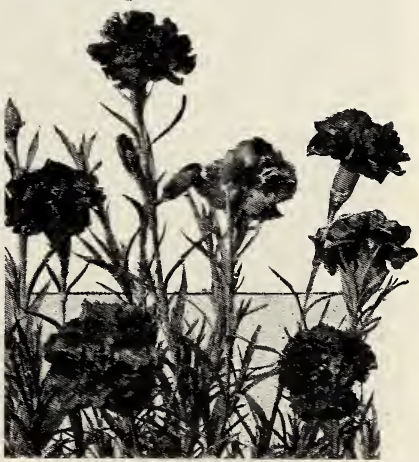

Hardy Border Carnations 

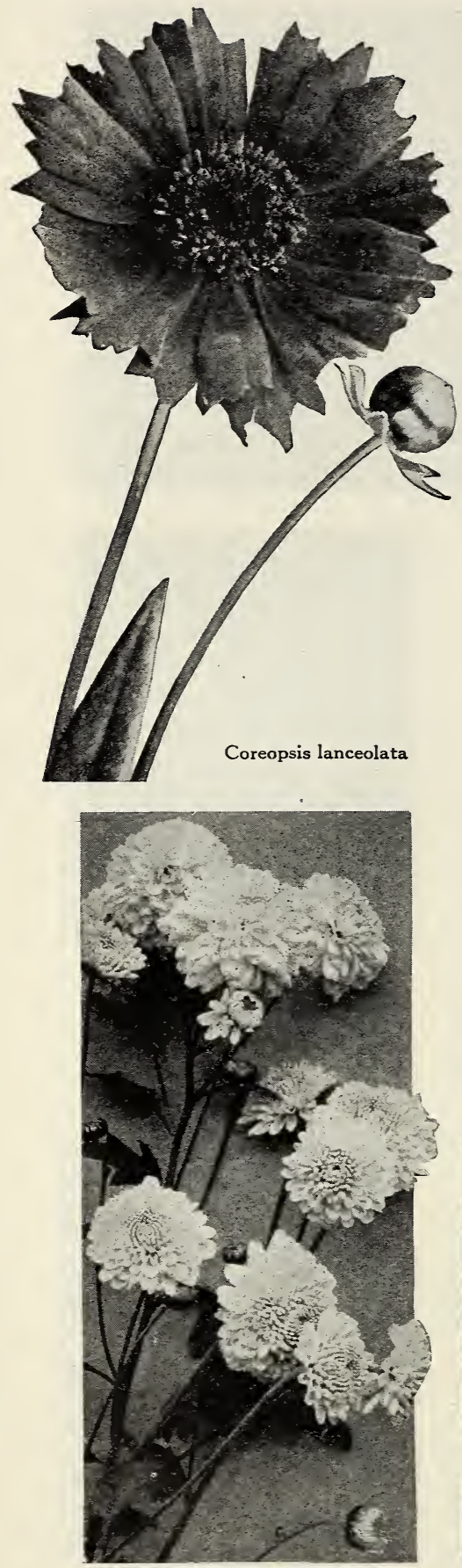

Double Chrysanthemums

\section{Cerastium - Snow-in-Summer}

Tomentosum. Grey-foliaged, trailing plants with masses of delicate white flowers in May and June. Delights in a dry, sunny location. Ht. 6 in. Pkt. 15 cts.; 4 pkts. 50 cts.

\section{Chelone - Turtlehead}

Torreyi. Beautiful, tubular-shaped, coral-pink flowers, blooming profusely from July to October. A favorite for backgrounds in rockeries. Ht. 3 ft. Pkt. 15 cts.; 4 pkts. 50 cts.

\section{Chrysanthemums}

These fine border plants produce a profusion of bloom which lasts well as cut-flowers. For other varieties see Annual List.

\section{Single Varieties}

Often called Hardy Daisies and make fine house plants.

Maximum, Mayfield Giant. A giant Daisy, with double row of snow-white petals. Ideal for cut-flowers. Will bloom first season from early-sown seed. Ht. $3 \mathrm{ft}$. Pkt. $25 \mathrm{cts}$; $1 / 4 \mathrm{oz}$. $\$ 1$.

Shasta Daisy, Alaska. Splendid flowers 3 inches across, of the purest glistening white, with broad overlapping petals. Will keep a week after cut. Ht. 3 ft. Pkt. 25 cts.; $1 / 4$ oz. $\$ 1$.

Shasta Daisy, Dwarf Giant-flowered. Growing only 2 feet high, the small, compact plants bear a rich profusion of big, white Daisies. These are very suitable for cutting as the long stems can be cut close to the ground. Pkt. 50 cts.

\section{Double Varieties}

Will produce about 75 per cent of double-flowering plants. Chinese and Japanese, Large-flowering. Will bloom the first year from early sown seed. Many blooms are double or partly double. Ht. 2 to $3 \mathrm{ft}$. Pkt. 25 cts.

Hardy Pompon Mixed. Old-fashioned fall-flowering sorts, with button-like blossoms. Ht. $11 / 2 \mathrm{ft}$. Pkt. 25 cts.

\section{Coreopsis - Tickseed}

Sow in June and transplant 2 feet apart. Give slight winter covering. Will flower the first year if sown in January. For annual varieties, see Calliopsis in the Annual List.

California Sunbeams. True golden yellow, cosmos-shaped flowers, on fine stems for cutting. Blooms freely all summer. Ht. 2 ft. Pkt. 15 cts.; $1 / 4$ oz. 50 cts.

Lanceolata grandiflora. Same as above except petals are lanced. Pkt. 10 cts.; $1 / 4$ oz. 35 cts.

Lanceolata grandiflora, Semi-double. (New.) These have double rows of golden yellow petals. Pkt. 25 cts.; 5 pkts. \$1.

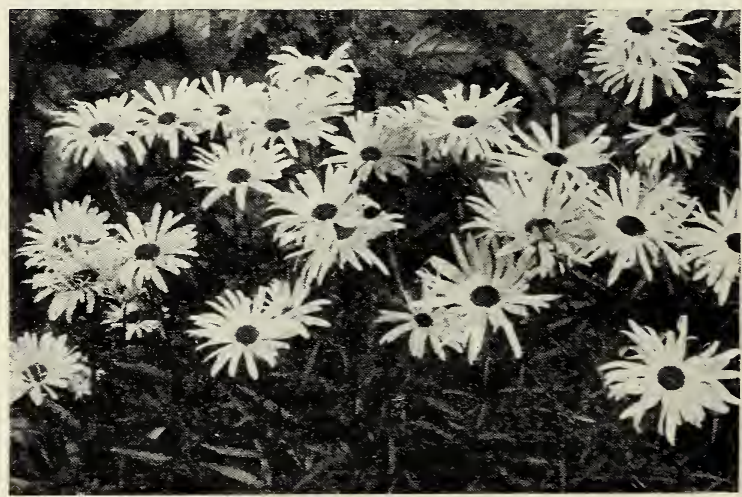

A bed of Shasta Daisies, Alaska 


\section{Delphinium - Perennial Larkspur}

The stately flower-spikes of these gorgeous Delphiniums tower above the chaste whiteness of Madonna and Regal lilies and break, with their gamut of blue, the monotony of phloxes, to Iater supplement chrysanthemums and asters.

Delphiniums demand rich, deeply cultivated soil and considerable moisture. If flowers are cut after blooming, and bonemeal added, others will replace them. Start seed in flats in March and later transplant seedlings when $3 / 4$ inch high to 4 inches apart. In May set the plants out in the border where they will bloom in midsummer. Place mature plants 3 feet apart. For other varieties, see Larkspur in the Annual List.

Watkin Samuels' Hollyhock-flowered and Wrexham Hybrids.

The deft magic of these great English hybridizers has endowed this new strain with flowers of superb size, exquisitely proportioned, on spikes like the tapered spires of ancient gothic cathedrals. These spikes range from 4 to 6 feet, with unusually long blooms of exquisitely colored florets-lovely tones of blues, mauves, lilacs, purples, and violets in indescribably wonderful variations. Pkt. $\$ 1$; 3 pkts. $\$ 2.50$. See our Plant Catalogue for Iarge fieldgrown clumps of named varieties of these Hollyhockflowered and Wrexham Delphiniums.

Giant Exhibition Hybrids, Blackmore and Langdon's Strain. This unusually fine mixture contains nearly all of the newest varieties developed by these famous English Delphinium specialists. Many of these hybrids have earned gold medal awards in England. The well-filled spikes are superbly colored and grow 6 to 7 feet high. Pkt. 75 cts.; 3 pkts. $\$ 2$.

Belladonna Hybrids (Everblooming Hardy Larkspur). This is the freest and most continuous blooming Hardy Larkspur. Not equaled for the delicacy and beauty of the flowers in clear turquoise and other blue shades. A really exquisite variety. Ht. $4 \mathrm{ft}$. Pkt. 50 cts.; 5 pkts. $\$ 2$.

Belladonna Improved. Large, strong spikes of a beautiful, clear turquoise-blue color. Pkt. 35 cts.; 4 pkts. \$1.

Formosum. Beautiful spikes of rich blue flowers, with a white center. Will bloom frrst season from early sown seed. Ht. $21 / 2$ ft. Pkt. 25 cts.; 5 pkts. $\$ 1$.

Gold Medal Hybrids. This is one of our most important specialties, and one of the finest strains of mixed hybrids. The plants are of strong, vigorous habit, 4 to 5 feet high, with Iarge flowers on spikes 2 feet long and over, the majority running in the lighter shades of blue. Pkt. 25 cts.; 5 pkts. $\$ 1$.

Tom Thumb. This miniature Delphinium grows 10 to 12 inches high, with strong spikes of ultramarine-blue flowers from June to October. Pkt. 25 cts.; 5 pkts. \$1.

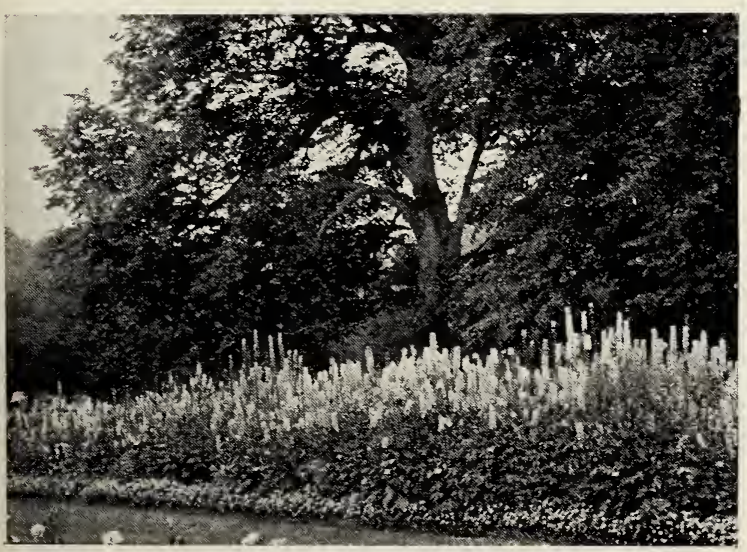

A beautiful Delphinium border

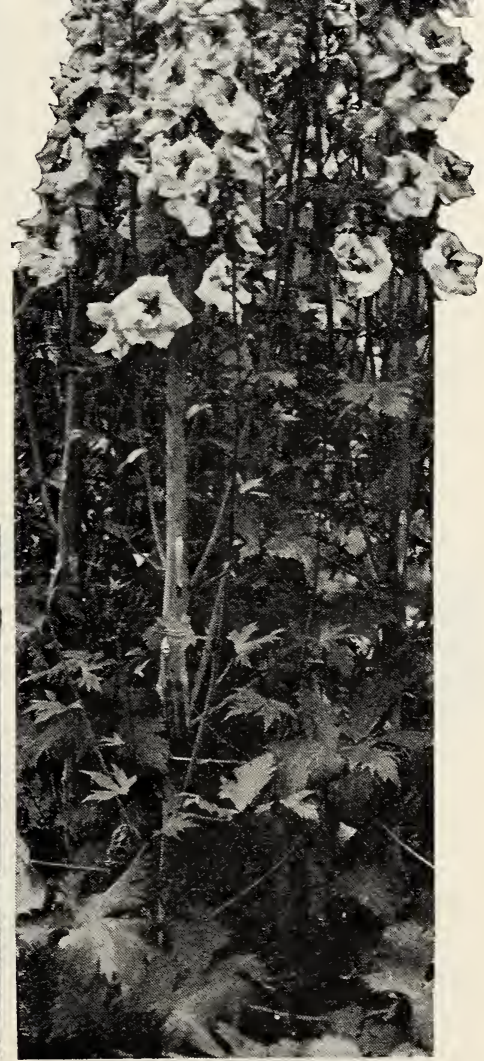

Wrexham Delphiniums 


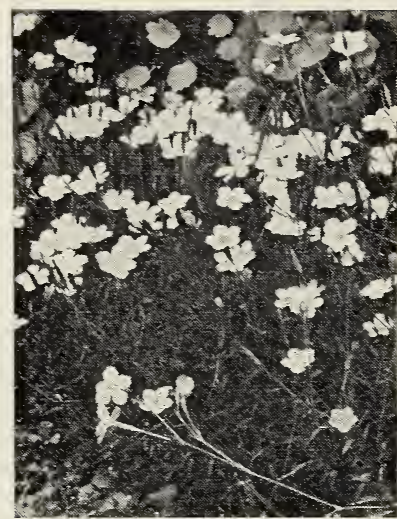

Dianthus deltoides

AII these Hardy Pinks are charming and easy to grow. They like sun, well-drained soil, and are at home in the rockery or when used for edging. With few exceptions they are very fragrant.

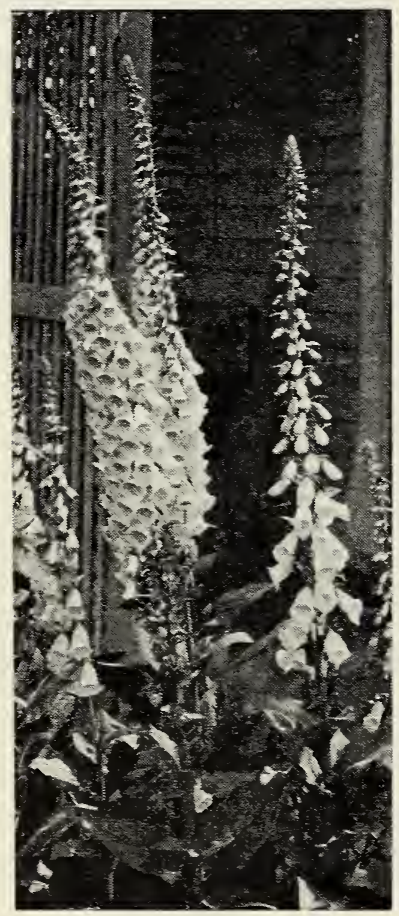

Digitalis gloxiniæflora

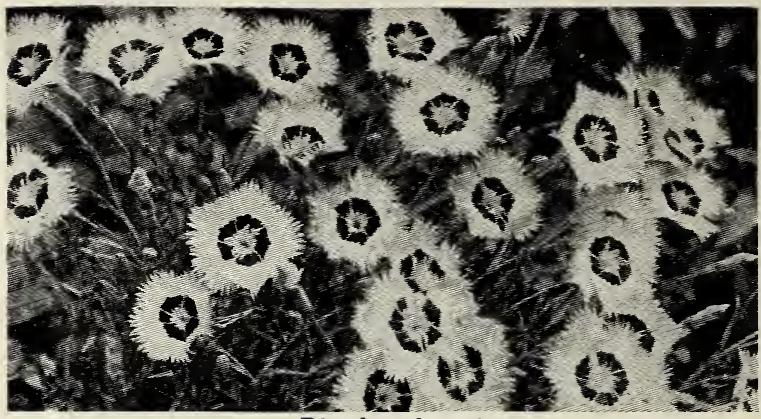

Dianthus plumarius

\section{Dianthus - Hardy Dwarf Garden Pinks}

These hardy perennials are unsurpassed for color and fragrance, and are splendid for borders. They bloom finely the first season, remaining green all winter and blooming the next year also, if lightly protected. Sow seed in the open in early spring when frost is past, and if the situation is open they will flower luxuriantly in a few weeks' time and continue until hard frost. Thin out seedlings to stand 6 inches apart. The double-flowering varieties are quite as fine as carnations for cutting. For annual dwarf varieties see Annual List.

Allwoodi, Mixed. A splendid strain, being half Carnation and half Pink. 75 per cent come double. Pkt. 50 cts.

Allwoodi alpinus. A wonderful plant for rock-gardens and stone walks. The tiny plants, only 4 inches high, are covered with small, Dianthus-like flowers ranging through purple, white, pink, and the darker rose shades. Pkt. 50 cts.

Barbatus. See Sweet William.

Deltoides (Maiden Pink). Beautiful, single coral-pink flowers with dark eye, borne 8 inches high in June and July, above grey foliage. Pkt. 25 cts.; 5 pkts. $\$ 1$.

Plumarius, Single Mixed (Pheasant's-Eye Pink). Large, single, fringed flowers, beautifully marked in many colors; delightfully fragrant. Will bloom the first season from earlysown seed. Ht. $1 \mathrm{ft}$. Pkt. $15 \mathrm{cts}$; $1 / 4 \mathrm{oz} .75 \mathrm{cts}$.

Plumarius, Double Mixed (Double Hardy Garden Pinks). Double and semi-double varieties. Pkt. $15 \mathrm{cts}$.; $1 / 4 \mathrm{oz} .75 \mathrm{cts}$.

Plumarius semperflorens (Everblooming Hardy Pinks). Very beautifuI, sweet-scented, double, semi-double, and single flowers in great diversity of color. Pkt. $25 \mathrm{cts}$.; $1 / 4 \mathrm{oz}$. \$1.

\section{Digitalis - Foxglove}

Beautiful biennial flowers for the tall border, with towering spikes of conical, bell-like blossoms and large, sage-green foliage at the base. Although they self-sow, they are best treated as biennials, blooming the second season from seed sown during spring or summer. Ht. 3 to $7 \mathrm{ft}$.

Canariensis. Pure, delicate canary-yellow. Ht. $3 \mathrm{ft}$. Pkt. 25c. Gloxiniæflora. Large, spotted, gloxinia-like flowers, produced on long spikes. Purple, White, Rose, or Mixed. Each, pkt. 10 cts.; $1 / 4$ oz. 50 cts.

Purpurea monstrosa, Mixed. A very unusual and showy form in which the upper flowers are united into one very large, cup-shaped blossom. Pkt. 15 cts.; 1/4 oz. 75 cts.

Shirley, New Giant. A new creation of Rev. Wilkes who introduced the Shirley poppy. The greatest improvement over Purpurea. It grows 7 feet tall. Color from white to dark rose and blotched form. Pkt. 25 cts.; 5 pkts. \$1.

\section{Edelweiss - Leontopodium}

Alpinum. A true Swiss alpine with downy white leaves and white, horned flowers having yellow, knotted centers in June and July. Ht. 5 in. Pkt. 25 cts. 


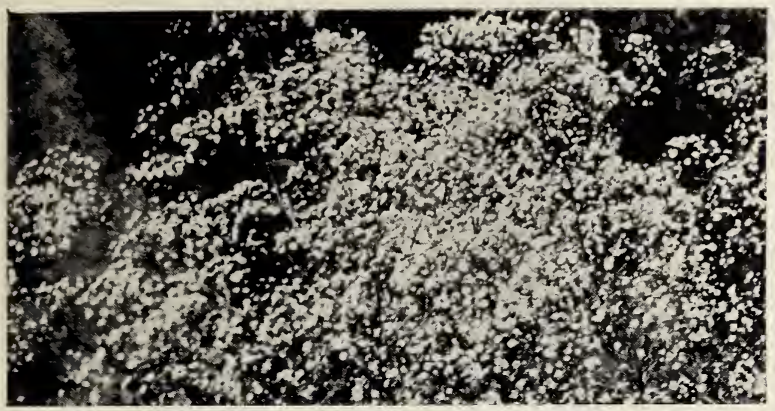

Gypsophila paniculata, Double, Snow-White

\section{Gaillardia}

Showy and handsome for beds and borders. The flowers are daisy-like with red petals tipped yellow having dark red centers. Sow in summer, transplanting to permanent positions during autumn. For other varieties see Annual List.

Grandiflora maxima. Very attractive golden yellow flowers held erect on long stems. WiII bloom the first season from early-sown seed. Ht. $21 / 2 \mathrm{ft}$. Pkt. $10 \mathrm{cts}$.; $1 / 4 \mathrm{oz} .50 \mathrm{cts}$.

Grandiflora, The Dazzler. This fine variety produces Iarger flowers, often 4 to 5 inches across. The color is a bright golden yellow, with rich maroon-red center. The plant is vigorous, throwing up a profusion of long, erect flowerstalks; excellent for cutting. Pkt. 25 cts.; 5 pkts. $\$ 1$.

Grandiflora, Portola Hybrids. New form in bronze-red, tipped with yellow and having beautiful foliage. Ht. 2 to $3 \mathrm{ft}$. Blooms from May to November. Pkt. 25 cts.; 5 pkts. $\$ 1$.

\section{Gentiana - Blue Gentian}

Beautiful border and rock-plant with shades of blue surpassing those found in any other family. Grows in moist, shady situation in sandy lime loam.

Acaulis (gentianella). Stemless, deep blue flowers from March to May. Ht. 4 in. Pkt. 25 cts.

\section{Geum - Avens}

A beautiful double flower much prized for its brilliance of color and earliness of bloom. Equally in demand as a border edging, rock-garden and cutting plant. Blooms from June to September and flowers the first year from seed sown outdoors in early spring.

Lady Stratheden. Has double yellow flowers from June to September. Ht. 2 ft. Pkt. 25 cts.

Mrs. Bradshaw. Dark orange-scarlet flowers like a double violet, borne 2 feet above a rosette of leaves. Pkt. 25 cts.

Orange Queen. Of a color between Lady Stratheden and Mrs. Bradshaw, beautifuI intense orange. Pkt. 50 cts.

\section{Gypsophila - Baby's Breath}

The well-known feathery tiny flowers so much used by florists in bouquets. For annual varieties see Annual List.

Paniculata (Baby's Breath). One of the favorite hardy perennials with minute white flowers; fine for bouquets. Blooms in June and July first year if sown early. Ht. 2 to $3 \mathrm{ft}$. Pkt. $10 \mathrm{cts}$.; $1 / 4 \mathrm{Oz}$. $50 \mathrm{cts}$.

Paniculata, Double, Snow-White. The double-flowering Baby's Breath. A fine hardy plant for cutting. Ht. 2 to 3 ft. Pkt. 25 cts.; 5 pkts. $\$ 1$.

Repens (Dwarf Baby's Breath). Has light grey foliage and pale rose flowers in June and July. Ht. 6 in. Pkt. 25 cts.

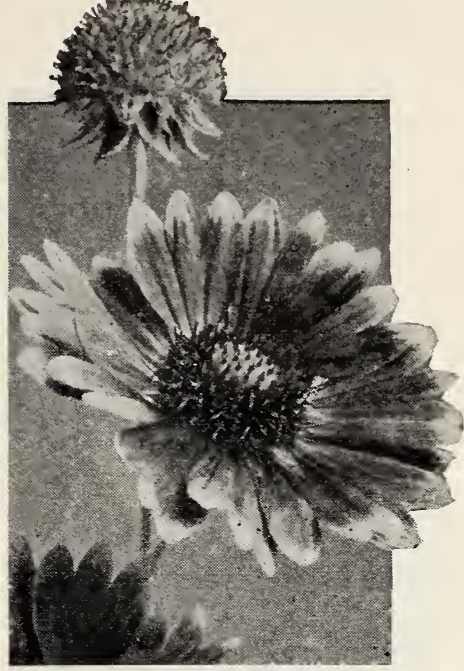

Gaillardia, Portola Hybrids

For cheerful, Iong-lasting garden color, Gaillardias are indispensable. Groupings of them here and there in front of shrubs will provide splotches of color for weeks and weeks. They like full sunshine and make a bright display during the summer weeks when other flowers are scarce. For cutflowers, too, Gaillardias are very valuable, providing fine long-stemmed, Iong - keeping flowers in brilliant color for brightening up the home.

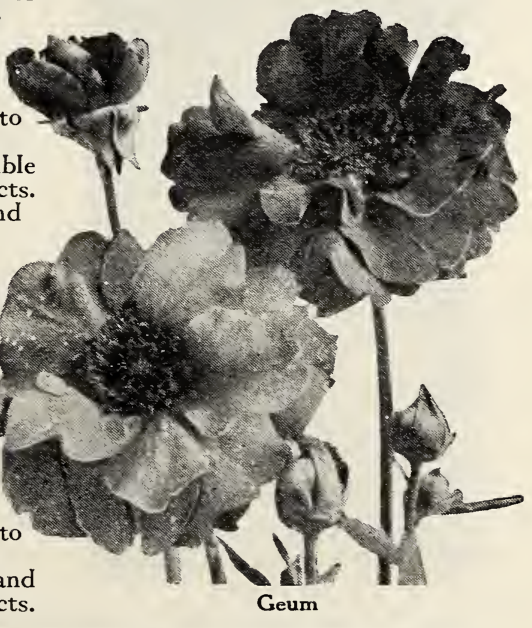




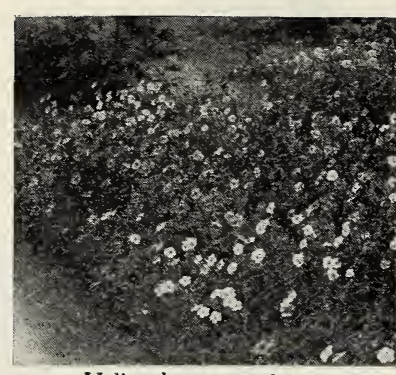

Helianthemum vulgare

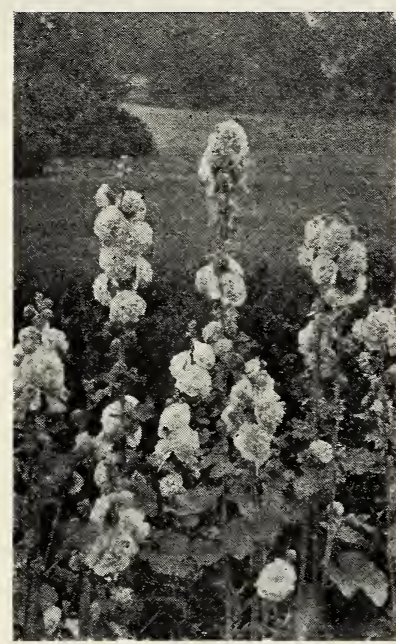

Hollyhock, Double Exquisite

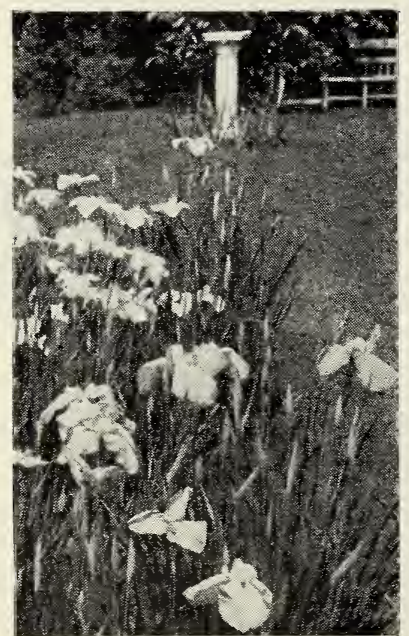

Japanese Iris

\section{Helianthemum - Rock Rose}

Vulgare mutabile. A shrubby evergreen with rose to white flowers with yellow bases in June and July. Good for sunny spots in the rock-garden. Ht. 8 to 12 in. Pkt. 15 cts.

\section{Heuchera - Coral Bells}

Sanguinea splendens. Coral-pink bells, above a whorl of leaves from May to September. Ht. 2 ft. Pkt. 25 cts.

\section{Hibiscus - Mallow}

Strong, bushy plants with Iarge flowers, like single hollyhocks, late in summer. Like a moist situation and last for years when once established. Sow indoors in March in pots.

Crimson Eye. Large, pure white flowers with velvety crimson centers. Ht. $4 \mathrm{ft}$. Pkt. $10 \mathrm{cts}$; $1 / 4 \mathrm{oz}$. $50 \mathrm{cts}$.

\section{Honesty - Moonwort}

Lunaria biennis. A biennial, admired for its silvery seedpouches, used for winter bouquets. It has beautiful crossshaped flowers. Sow in open in May, protect over winter. Ht. 2 ft. Purple or White. Each, pkt. $10 \mathrm{cts}$.; 1/4 oz. $50 \mathrm{cts}$.

\section{Hollyhock}

A hardy biennial of upright, stately growth, 5 to 8 feet high. The very double varieties are the most desirable, but the newer, semi-double, fringed types are also very popular. Hollyhocks make a fine row in a garden, or background next to a building or high wall. From seed sown in early spring, they may produce a few flowers in late summer, but are best the second year. For annual varieties see Annual List.

Double Exquisite. Flowers very double, each petal exquisitely curled and fringed, with a broad margin of white, the centers being shades of rose, carmine, purple, and violet. In form they suggest the beautiful double fringed petunias while in color they resemble the pelargoniums. Lovers of Hollyhocks will welcome this magnificent new type. Pkt. 25 cts.; 5 pkts. $\$ 1$.

Superb Double. Tall spikes, closely set with wonderfully showy, double flowers. Many will flower the first season from seed sown the previous fall. They reseed themselves; a bed will last for years. Ht. $7 \mathrm{ft}$. Salmon-Rose, Scarlet, Pure White, Maroon, Light Yellow, Newport Pink, or Mixed. Each, pkt. 15 cts.; $1 / 4$ oz. $\$ 1$.

Fringed Single Hybrids, Mixed. These come in white, pink, rose, yellow, and maroon. The plants are more hardy and permanent than the double varieties. Pkt. $15 \mathrm{cts}$; $1 / 4 \mathrm{oz}$. $\$ 1$.

\section{Incarvillea - Fairy Trumpets}

Grandiflora. This has large, rose trumpet-shaped flowers on stems $11 / 2$ feet high above fern-like foliage in June and July. Likes a sunny location. Pkt. $50 \mathrm{cts}$.

\section{Iris Kaempferi}

Japanese, Mixed. Showy perennial plants with grass-like leaves used extensively in the hardy border. Flowers are enormous in violet, purple, white, blue, blue-violet, and veined, with yellow centers. Blooms in July of the second year. Seed germinates very slowly. Ht. 1 to $3 \mathrm{ft}$. Pkt. 15 cts.; $1 / 4 \mathrm{oz}$. 75 cts.

\section{Lavender • Lavandula vera}

True Lavender. Popular sweet-scented hardy perennial; fine for sunny borders. Give winter protection. Long spikes of fragrant blue flowers with grey foliage. Needs light soil. Ht. $3 \mathrm{ft}$. Pkt. $15 \mathrm{cts}$; $1 / 4 \mathrm{oz} .50 \mathrm{cts}$. 


\section{Linaria}

Cymbalaria (Kenilworth Ivy). Lavender and purple. A charming, neat, hardy perennial trailing plant, for baskets, vases, or rockeries. Pkt. 15 cts.; 2 for 25 cts.

\section{Linum - Blue Flax}

Perenne, Blue. Showy plants of Iong duration, having fine foliage and delicate stems, with deep blue flowers from May to August. Ht. $11 / 2$ ft. Pkt. $10 \mathrm{cts}$.; $1 / 4 \mathrm{oz}$. $35 \mathrm{cts}$.

\section{Lobelia}

Tall hardy perennial, with showy spikes of richly colored flowers. They are indispensable for permanent beds and do best in rich moist soil. For other varieties see Annual List.

Cardinalis (Cardinal Flower). Long, full spikes of intense flaming scarlet flowers, with green foliage. Fine in shrubbery. Ht. 2 ft. Pkt. 25 cts.; 5 pkts. $\$ 1$.

Cardinalis, Queen Victoria. Very brilliant scarlet spikes with bronze foliage. Pkt. $50 \mathrm{cts}$.

\section{Lupinus Lupine}

This pea-shaped flower, with grey-green leaves, succeeds in any garden soil, and blooms in May and June. Do not transplant. Ht. $3 \mathrm{ft}$. For other varieties see Annual List.

New Hybrids, Polyphyllus-arboreus. This beautiful new type, the result of crossing L. polypbyllus and L. arboreus, combines the characteristics of both and embraces new and rare colors heretofore never seen in Lupines. The plants grow 4 to 5 feet tall in a large bushy form. This is an excellent perennial plant for the border and invaluable for cutting. We offer this unusual strain in six colors: Captivation (soft blue); Downer's Delight (deep rose); Evening Glow (mauve and yellow); Queen of the West (soft primrose); Seraphine (mauve and goId); Zulu (deep violet-purple). Each, pkt. 50 cts. or 1 pkt. each of all 6 for $\$ 2.50$.

Polyphyllus. Blue, White, or Mixed. Pkt. 15 cts.; oz. 75 cts. Rose. True rose, a rare color in Lupines. Pkt. 25 cts.; oz. $\$ 1$.

\section{Lychnis - Campion}

Handsome hardy perennials, for massing in beds, blooming the first year, if sown early. Easy to grow and thriving in poor soil. Petals arranged like a Maltese Cross.

Chalcedonica, Scarlet. Erect plants, with clusters of flowers at the top. Ht. $2 \mathrm{ft}$. Pkt. $15 \mathrm{cts}$.

Haageana Hybrids. Orange, scarlet, crimson flowers over 2 inches across in May and June. Ht. $1 \mathrm{ft}$. Pkt. 15 cts.

SaImon Queen. (New.) A beautiful salmon-rose. Pkt. 25 cts.

Viscaria splendens (German Catchfly). Fragrant, rose-pink and crimson flowers resembling double pinks, and evergreen foliage. Blooms in May and June. Ht. $1 \mathrm{ft}$. Pkt. $15 \mathrm{cts}$.

\section{Meconopsis - Thibetan Poppy}

Baileyi. This recent introduction is a perfectly hardy perennial poppy, growing 2 to 3 feet high, and freely bearing beautiful sky-blue blooms with golden yellow anthers. It is a flower of very unusual beauty. Pkt. 50 cts.

Integrifolia maxima. These beautiful Poppies are alpine biennials, 1 to 3 feet taII, with Iarge flowers of bright sulphuryellow. They were found growing in the Himalaya Mountains by Captain Kingdon Ward and brought to England where they were awarded the First-Class Certificate of the Royal Horticultural Society. Pkt. 50 cts.

Wallichi (Satin Poppy). Resembles Iceland Poppy in its grey-green foliage, but differs in its satin-crinkled flower of pale blue. Plant in a cool, moist, shady location. It grows 4 feet high and is a native of western China. Pkt. 50 cts.

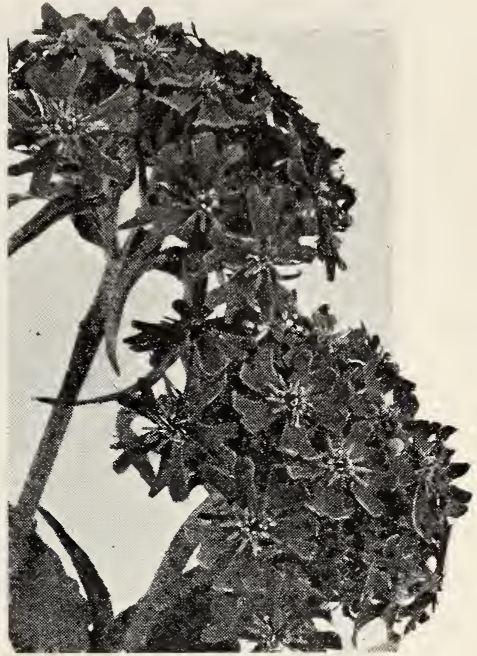

Lychnis chalcedonica

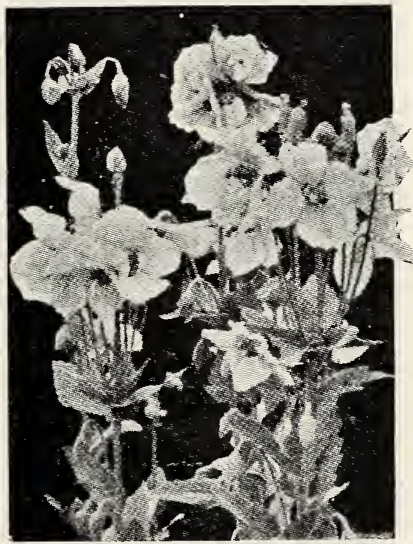

Meconopsis Baileyi

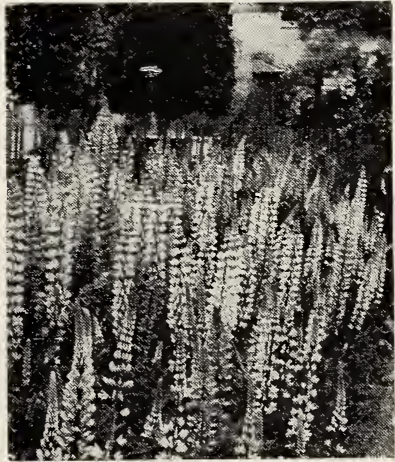

Lupinus polyphyllus 


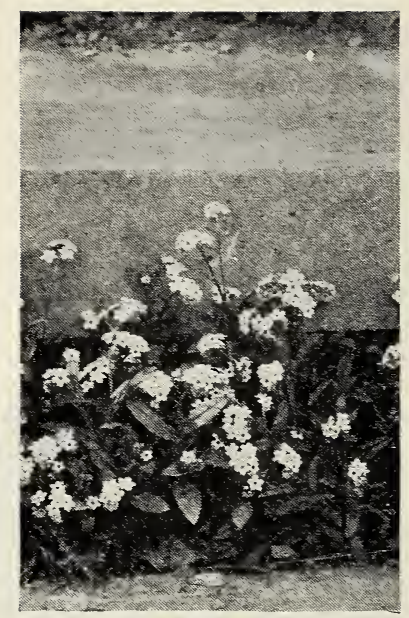

Myosotis palustris

Plant Forget-me-nots over the tulip-beds, or mix them with primroses in a shady corner of the garden. They are splendid for edging.

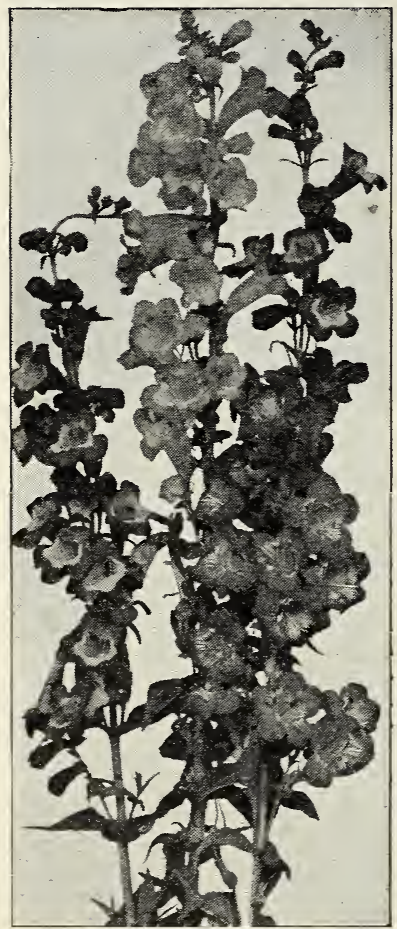

Pentstemon, Sensation

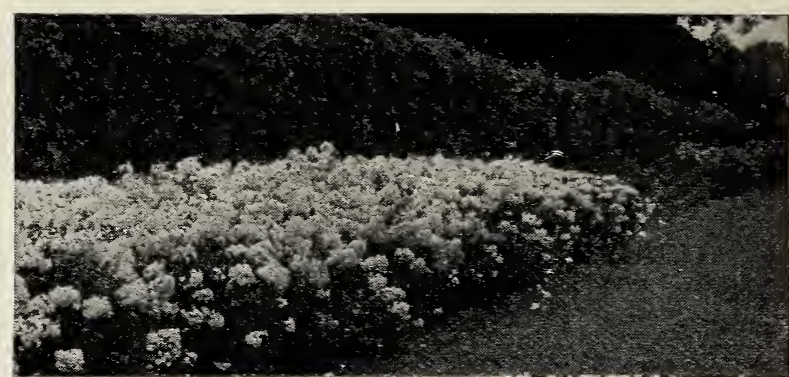

A permanent border of Phlox decussata

\section{Myosotis - Forget-me-not}

Lovely little plants for moist and shady situations. Sow seed in late spring or early summer for blooming the following season. Protect over winter. The plants can be Iifted in the fall for winter flowering. For other varieties see Annual List. Palustris. The true Forget-me-not. Dainty, pale blue flowers on dwarf, bushy plants 8 inches high. Blooms from June to October. Pkt. 20 cts.; $1 / 8$ oz. $\$ 1.50$.

Palustris semperflorens. Pale blue flowers in pretty sprays from May until autumn. Pkt $15 \mathrm{cts}$.; $1 / 80 z$. $\$ 1.25$.

\section{Nepeta - Caucasian Catmint}

Mussini. Blue-lavender spikes profusely borne from April to June. It is a good edger with sheets of grey-green foliage. Ht. 8 in. Pkt. 25 cts.

\section{CEnothera - Evening Primrose}

It is very interesting to watch the flowers unfold their petals at twilight. Sow seed outdoors in May.

Lamarckiana. This bears sweet-scented, golden yellow flowers from July to October. Ht. $3 \mathrm{ft}$. Pkt. $10 \mathrm{cts}$; $1 / 4 \mathrm{oz} .50 \mathrm{cts}$. Missouriensis. Large, golden yellow flowers on trailing stems from June to August. The leaves are erect, like small palm fronds. Ht. 10 in. Pkt. 25 cts.

\section{Pentstemon}

Border plants which grow continuously an abundance of brilliant flowers, somewhat like the foxglove, but with white throats. Sow seeds in a pan of light soil and transplant. Coral Pink. A charming, hardy border plant 2 to 3 feet high with a profusion of coral-pink bloom. Pkt. 25 cts.; 5 pkts. $\$ 1$. Sensation. As a bedding plant this takes rank with the petunia, phlox, etc. It grows about 2 feet high, every branch being a spike of large, gloxinia-like flowers in bright colors, including rose, red, carmine, cherry, pink, lilac, purple, etc. Not quite hardy, and best treated like petunias, verbenas, salvia, etc. Pkt. 15 cts.; 2 pkts. 25 cts.

\section{Phlox Decussata}

Splendid hardy border flowers, lasting for years when established on good soil, and blooming from July to September. Seed germinates slowly.

Tall Large-flowered Mixed. From selected varieties, in white, pink, salmon, rose, crimson, and lavender. Ht. $3 \mathrm{ft}$.

Dwarf Large-flowered Mixed. Same but about $1 \frac{1}{2}$ feet high. Each, pkt. 25 cts.; 5 pkts. \$1 


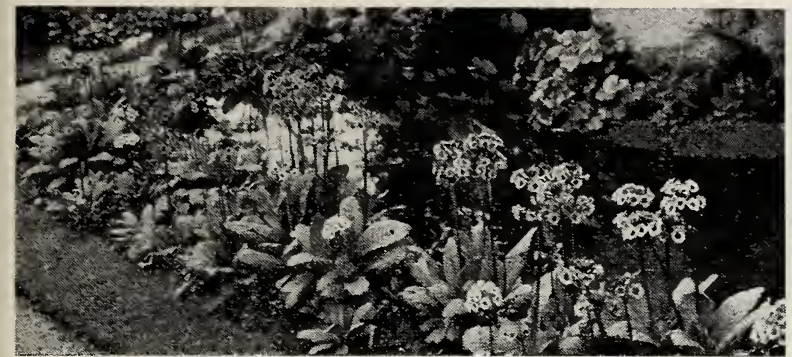

An effective planting of Primula japonica

\section{Platycodon - Chinese Bellflower}

A hardy perennial bearing large, broad, star-shaped bells which are very handsome for garden decoration. Blooms in Auguist from seed sown outdoors in April.

Grandiflora. After the plants are well established they bear flowers 3 inches across in June and July. Ht. $2 \mathrm{ft}$. Blue or White. Each, pkt. 15 cts.; 1/4 oz. \$1.

Mariesi. Dwarf habit, with deep blue flowers in June and July. Ht. $1 \mathrm{ft}$. Pkt. $15 \mathrm{cts}$.

\section{Hardy Perennial Poppies}

There are no flowers more ornamental and useful than Poppies. They increase in size and beauty each season.

Iceland, Giant Orange. This new color is a pure orange without any trace of red. It is unusually brilliant, and is accentuated by the green foliage. Pkt. 35 cts.

Iceland, Double Mixed (Papaver nudicaule). Very graceful, dwarf, tufted plants bearing many dainty flowers throughout the summer. It comes in white, yellow, and orange. Lasts well if cut when in bud and flowers the first year from earlysown seed. Ht. $1 \mathrm{ft}$. Pkt. $15 \mathrm{cts}$; $1 / 4 \mathrm{oz}$. $75 \mathrm{cts}$.

Iceland, Single Mixed. Free-flowering in colors as above. Pkt. 15 cts.; $1 / 4$ oz. 75 cts.

Orientale (Oriental Poppy). A charming, showy, early summer-flowering plant, with large orange-scarlet blooms, each petal being blotched with black. Sow seed in open ground early in the spring. Ht. 2 to $3 \mathrm{ft}$. Pkt. $15 \mathrm{cts}$.; $1 / 4 \mathrm{oz}$. $\$ 1$.

Orientale Hybrids. White, blood-red, salmon and scarlet, blooming in June and July. Pkt. 15 cts.; 1/4oz. \$1.

Orientale, Mrs. Perry. Clear salmon-pink with black blotches at the center. It fills a need where the scarlet and orange forms clash with early pink Peonies. Pkt. 25 cts.; 5 for $\$ 1$.

Sunbeam Bouquet. A new race, resembling the Iceland; in maize, creams, and tones of rose. Blooms from June to September. Ht. $1 \mathrm{ft}$. Pkt. 25 cts.; 5 pkts. $\$ 1$.

\section{Primula}

These are among the best of the early spring-blooming plants. Useful for rockeries and shaded borders and for potculture. With slight protecticn they will stand the winter, but will do better if protected by a coldframe.

Auricula. Maroon, purple, crimson, and yellow flowers in umbels in April and May. Ht. 6 in. Pkt. 25 cts.; 5 pkts. $\$ 1$.

Cashmeriana. Early-flowering hybrids, producing large heads of white, mauve, purple, and violet flowers. Pkt. 50 cts.

Japonica, Mixed. Fine for the garden, producing several whorls of large flowers, on erect stems, varying from white to crimson. Ht. $11 / 2 \mathrm{ft}$. Pkt. 25 cts.; 5 pkts. $\$ 1$.

Polyanthus. Colors range from white to deep maroon, yellow, rose, and crimson. Ht. 9 in. Pkt. 25 cts.; 5 pkts. $\$ 1$.

Veris, Officinalis Hybrids, Mixed (Cowslip). Bright blue and white flowers in April and May. Ht. 6 to 8 in. Pkt. 25 cts.

Vulgaris (English Primrose). Fragrant, pale yellow flowers in April. The plants are hardy. Ht. 9 in. Pkt. 25 cts.

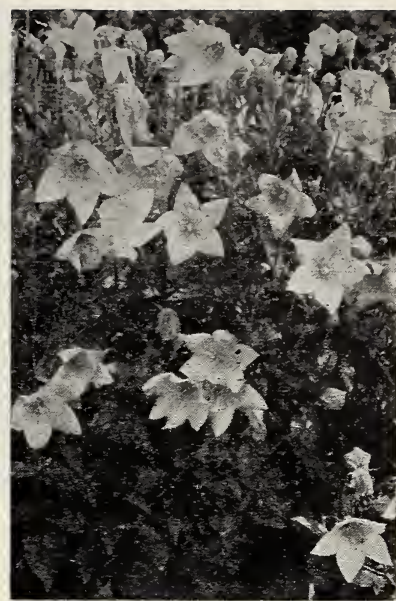

Platycodon grandiflora

Platycodons come after Canterbury Bells, prolonging the same beautiful effect. It takes them a year or two to become established.

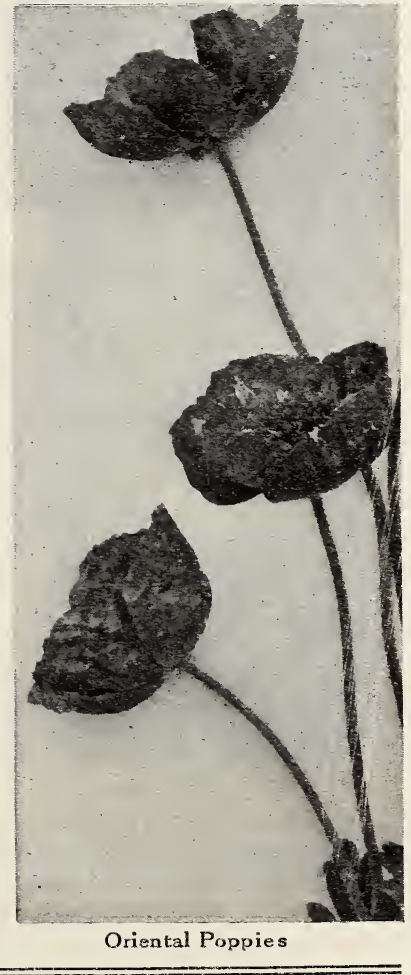




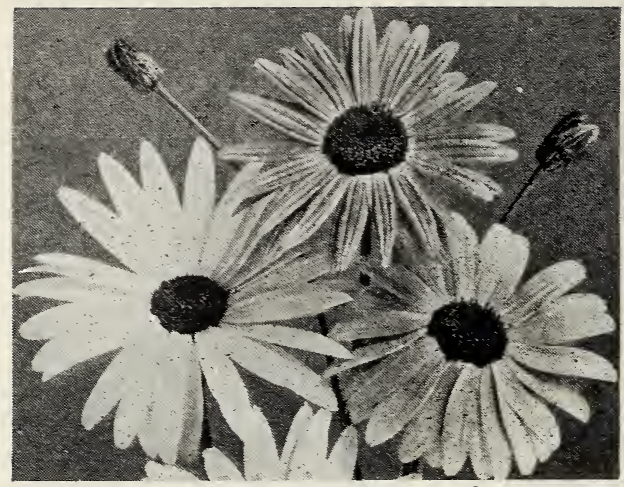

Pyrethrum, Select Single Hybrids

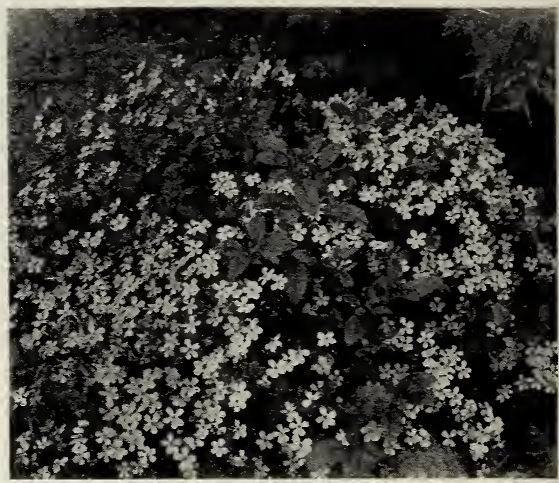

Saponaria ocymoides

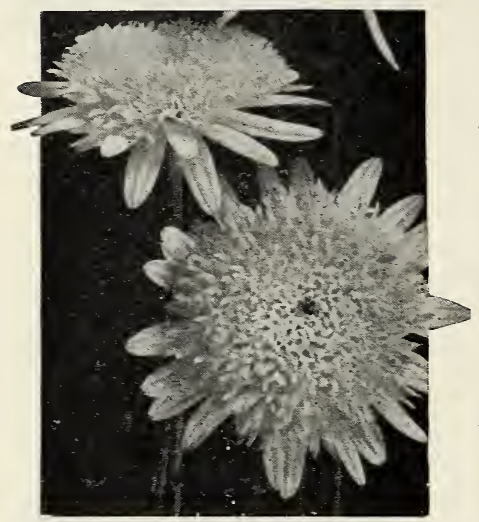

Double Hybrid Pyrethrum

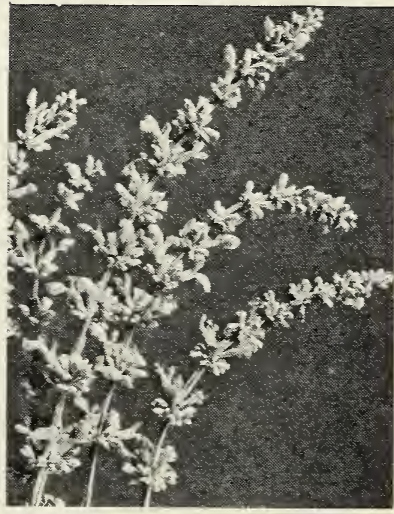

Salvia farinacea

Salvia farinacea is especially handsome when grown behind a line of soft pink petunias. It is handsome for many weeks.

\section{Pyrethrum - Painted Daisy}

No hardy border should be without these charming plants, as their flowers and foliage make the garden delightful.

Atrosanguineum. Daisy-like, dark carmine flowers elegant for cutting. Plants are hardy. Ht. 2 ft. Pkt. 25 cts.; 5 pkts. \$1. Select Double Hybrids. Similar to the Select Single Hybrids below, except that centers are tufted, resembling a double China Aster. Ht. $21 / 2 \mathrm{ft}$. Pkt. 25 cts.; 5 pkts. $\$ 1$.

Select Single Hybrids. Flowers range from the palest pinks to deep red, the bright yellow centers forming a lovely contrast. They bloom during May and again in the fall. Excellent for cut-flowers. Ht. $2 \frac{1}{2} \mathrm{ft}$. Pkt. 25 cts.; 5 pkts. $\$ 1$.

\section{Salvia}

Farinacea, Blue. A perennial variety, but best grown as an annual. Seeds sown in the open ground in May bloom from July to frost. The light blue flower-spikes contrast nicely with yellow flowers. Ht. 2 ft. Pkt. 15 cts.; $1 / 80 z .75$ cts.

\section{Santolina - Lavender Cotton}

Tomentosum. A very finely cut, Iavender-grey-foliaged evergreen plant, small yellow flowers. Ht. $11 / 2 \mathrm{ft}$. Pkt. $25 \mathrm{cts}$.

\section{Saponaria - Rock Soapwort}

Ocymoides. Rock-plant with grey foliage and sheets of crimson flowers in May and July. Ht. $1 \mathrm{ft}$. Pkt. 15 cts.

\section{Saxifraga - Rockfoil}

Decipiens grandiflora. An alpine with a massing of charming white flowers from April to May. Ht. $11 / 2 \mathrm{ft}$. Pkt. $35 \mathrm{cts}$.

Species Mixed. White, rose, carmine and purple Alpine Saxifrage blooming in April and May. Ht. $1 \mathrm{ft}$. Pkt. 25 cts.

\section{Scabiosa - Pin-Cushion Flower}

This easily grown cutting and garden flower blooms from July until frost. Plant 1 foot apart and keep flowers cut to prolong bloom. For other varieties see Annual List.

Caucasica. Hardy with large, pale blue flowers on long stems; valuable for cutting. Ht. $3 \mathrm{ft}$. Pkt. $15 \mathrm{cts}$.; $1 / 8 \mathrm{oz}$. $\$ 1$.

Columbaria. South Africa has given us this very low-growing, hardy plant with flowers 2 to $21 / 2$ inches across in two colors: Lavender-Blue and Pink. Each, pkt. 50 cts.

Japonica. Beautiful Iavender-blue flowers on $21 / 2$-foot, bushy plants. Pkt. 15 cts.; $1 / 8$ oz. \$1. 


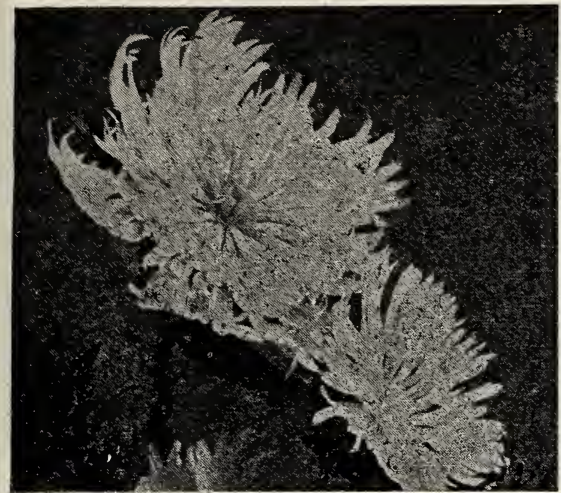

Stokesia cyanea

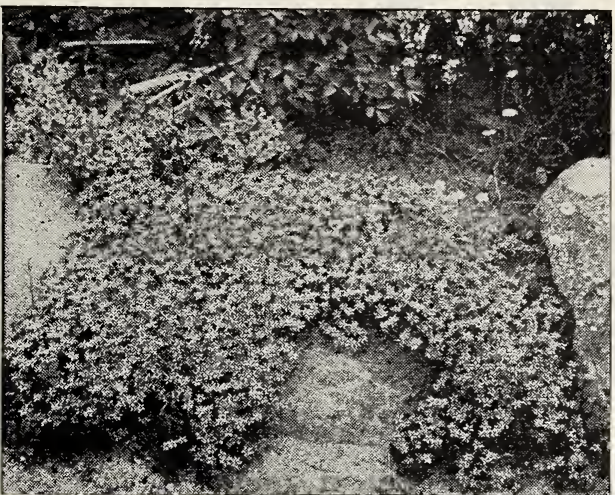

Sedum acre

\section{Sedum - Stonecrop}

Acre (Golden Moss). Has grey fleshy leaves and flowers or bright yellow. Fine for rockeries and edging. Blooms from May to July. Ht. 2 to 3 in. Pkt. 25 cts.

Anglicum (White and Pink Stonecrop). Has grey-green foliage and white and pink blooms in May. Ht. 4 in. Pkt. 25 cts.

Fabaria (Rose Stonecrop). Has rose blooms in April and May. Ht. 4 in. Pkt. $25 \mathrm{cts}$.

\section{Sempervivum - Houseleẹk}

Mixed. An assortment of hardy plants important to every rock-garden. They have fleshy rosettes of green and bronze shades. Ht. 6 to 12 in. Pkt. 25 cts.

\section{Sidalcea}

This is a charming hardy perennial with long, graceful spikes of mallow-like flowers, measuring $11 / 2$ to 2 inches across. It is most satisfactory for cutting and for the border.

Hemsley's New Hybrids. This is a fine improvement over the older strains with Iarger flowers embracing beautiful shades of pink, salmon, red, and white. The plants, 2 to 3 feet high, continue in bloom from June to September. Pkt. 50 cts.

\section{Statice - Sea Lavender}

Makes borders gay for a long time with its cloud-like masses of flowers of delicate color and graceful habit. Used to lighten bouquets. For other varieties see Annual List.

Incana (Sea Lavender). White panicles of flowers borne above clumps of large leaves from August to September. Plant in the rock-garden. Ht. 1 to $2 \mathrm{ft}$. Pkt. $10 \mathrm{cts}$.

Latifolia. Has large, branching heads of blue flowers invaluable for the perennial border and to dry for winter decoration. Ht. 2 ft. Pkt. 15 cts.

\section{Stokesia - Cornflower Aster}

Cyanea, Blue. A rare and beautiful plant with handsome, cornflower-like, pale blue blossoms, 3 inches in diameter, from July till frost. Fine for the hardy border and for cutting. Ht. $2 \mathrm{ft}$. Pkt. 15 cts.; $1 / 4 \mathrm{oz}$. $\$ 1$.

\section{Sweet Rocket - Hesperis}

Produces clusters of sweet-scented flowers, nice for the borders and for cutting. Thrives in poor soil. Ht. $2 \mathrm{ft}$. White or Purplish Pink. Each, pkt. $10 \mathrm{cts}$; 1/80z. $25 \mathrm{cts}$.

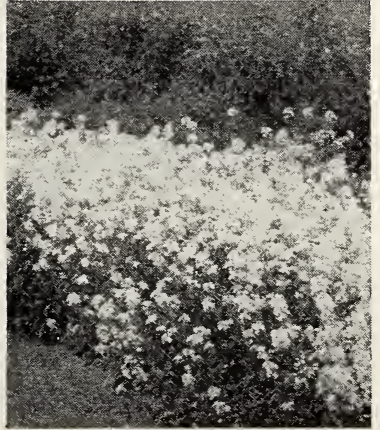

Sweet Rocket

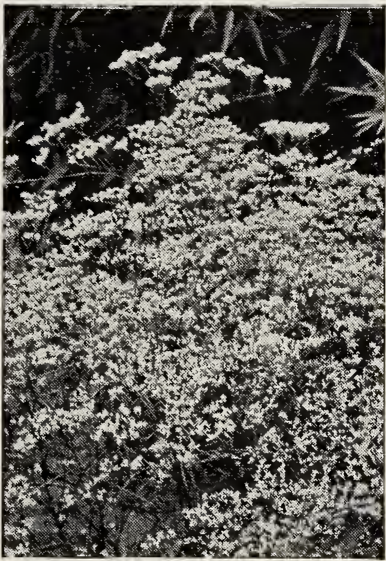

Statice latifolia

AII of the Stonecrops or Sedums are excellent rockplants, grow rapidly, and thrive on neglect in the most unhospitable places. 


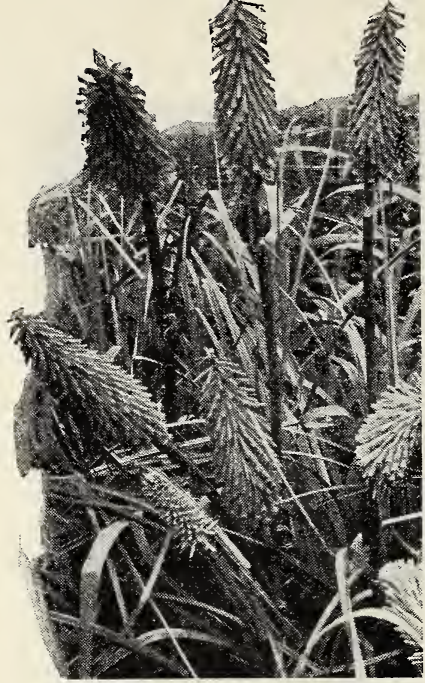

Tritoma Hybrids

Try Newport Pink Sweet William in front of Delphinium with white Snapdragons or other white flowers.

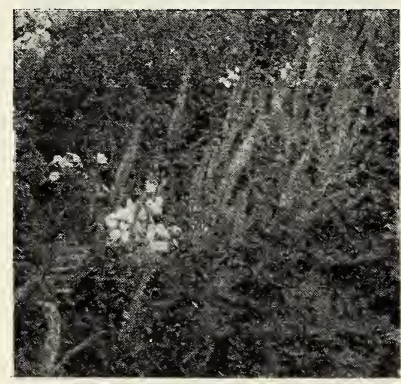

Veronica prostrata

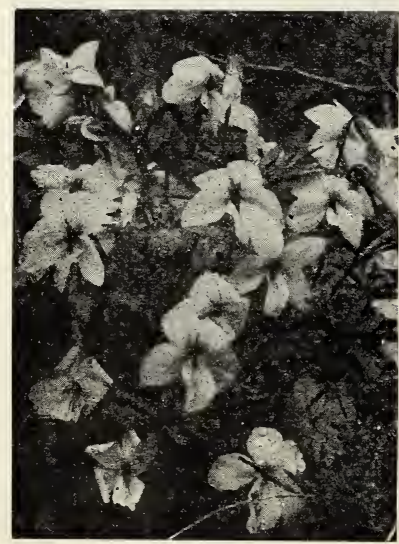

Viola odorata

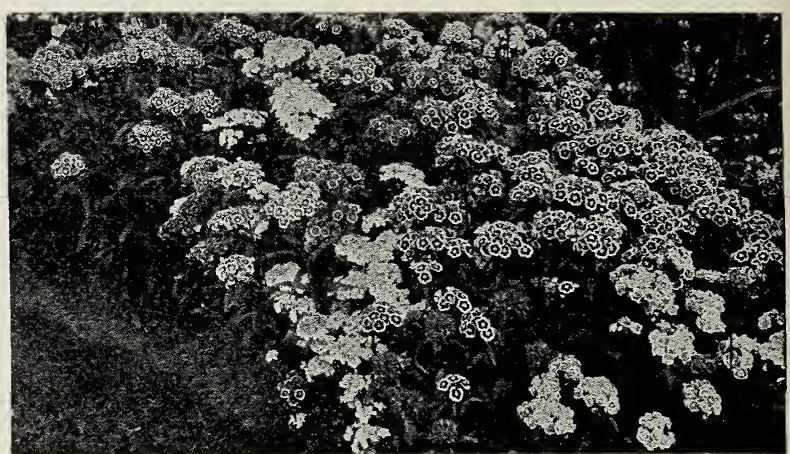

Sweet William

\section{Sweet William (Dianthus barbatus)}

A free-flowering, hardy perennial, that is splendid in beds and borders with its rich and varied flowers. Sow seed August 1 and transplant in September to sunny borders. If sown in early spring, will not bloom until the second season.

Holborn Glory. This single strain has individual flowers and trusses of extraordinary size, each flower showing a clear, white eye. Pkt. 15 cts.; $1 / 4 \mathrm{oz} .75$ cts.

Newport Pink. A distinct new color in Sweet Williamssalmon-pink. The flowers are borne in massive heads, on stems $1 \frac{1}{2}$ feet high. It has no equal for midseason mass bedding and for cutting. Pkt. 15 cts.; $1 / 4 \mathrm{oz} .75$ cts.

Scarlet Beauty. Superb, vivid scarlet blooms, 2 feet tall, in May and June. Pkt. 15 cts.; $1 / 4 \mathrm{oz} .75$ cts.

Single. Charming combinations of color are easily effected by planting the separate colored varieties. Crimson, White, Black-Red, or Mixed. Each, pkt. $10 \mathrm{cts}$; $1 / 4 \mathrm{oz} .50 \mathrm{cts}$.

Double. Fine for bedding where full-flowered masses of separate colors are wanted. White, Crimson, Black-Red, Rose, or Mixed. Each, pkt. 15 cts.; $1 / 4$ oz. 75 cts.

Dwarf Double Mixed. Large, full, double, compact blooms on stems 6 to 8 inches high, in white, pink, and red. Pkt. 15 cts.; $1 / 4$ oz. 75 cts.

\section{Tritoma - Red Hot Poker}

Stark's Perpetual Early-flowering Hybrids. A valuable halfhardy border plant. If sown indoors February 1, the plants will produce their attractive salmon and scarlet, thick flowerspikes in August and September. Ht. 3 ft. Pkt. 25 cts.; 5 pkts. $\$ 1$.

\section{Valeriana - Garden Heliotrope}

Showy, hardy plants with deeply cleft leaves and Iarge heads of white and red flowers on 3 to 5 foot stems, emitting a delicate heliotrope odor.

Mixed. Pkt. 10 cts.; $1 / 40 z .25$ cts.

\section{Veronica - Speedwell}

Prostrata. A dwarf kind of the ever-popular Speedwell, with spikes of deep blue in June and July. Ht. 6 in. Pkt. 25 cts.

Repens. The plants of this early native variety are of trailing habit with blue and white flowers from April to June. Ht. 3 in. Pkt. 25 cts.

\section{Viola • Violet}

Odorata (Sweet-scented English Violet). A very fragrant, large-flowered strain that is quite hardy. Blue and White. Each, pkt. 25 cts.; 5 pkts. $\$ 1$. 


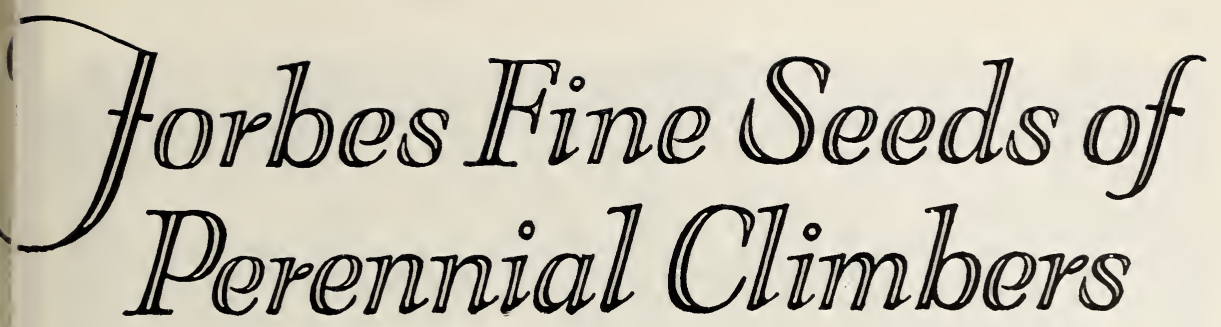

These climbers, with their light texture, excel in softening the lines of fences, in festooning lattices, and in enhancing arbors and doorways, or, with their heavy texture, in screening unsightly views. Sow seed in fall, and transplant in spring, unless otherwise noted.

\section{Adlumia - Mountain Fringe}

Cirrhosa (Allegheny Vine). A light, hardy, 15-foot biennial vine. In toth pink flower and Ieaf delicacy it resembles Bleeding-Heart. Sow in spring and transplant in fall; it thrives in semi-shade and leaf-mold. Pkt. 25 cts.

\section{Ampelopsis - Boston Ivy}

Veitchi. A hardy perennial climber with three-part leaves which turn to vivid scarlet in the autumn. The best covering for brick and stone walls. It needs no support, stands dust and smoke from chimneys very well. Pkt. 10 cts.

\section{Aristolochia - Dutchman's Pipe}

Sipho. Rapid-growing, luxuriant, hardy perennial climber with large, heart-shaped leaves and curious brown-purple flowers, resembling pipes. Fine for screens and covering unsightly objects. Ht. $30 \mathrm{ft}$. Pkt. $10 \mathrm{cts}$.

\section{Bittersweet - Celastrus scandens}

This native plant of rapid growth, succeeds in almost any situation, sun or shade, has attractive light green foliage and small cream flowers during June, followed in autumn by bright orange capsules which burst to show red berries and remain on the plant throughout the winter. Pkt. 25 cts.

\section{Clematis}

One of the best medium climbers for trellis and veranda, seldom diseased, and grows 15 to 20 feet high.

Paniculata (Virgin's Bower). Star-like, small, scented blossoms, followed by grey ostrich-feathered seeds in September. Pkt. 15 cts.; 4 pkts. 50 cts.

Jackman's Hybrids. Have large, star-shaped blooms 6 inches across, deep violet, red-violet, or white, in both single and double form. Pkt. 25 cts.; 5 pkts. \$1.

\section{Kudzu Vine - Pueraria}

Japanese. Hardy climbing plant growing 8 to 10 feet the frrst year from seed. After established it will climb 25 to 50 feet in a season, freezing down each winter but coming up from the roots again in the spring. This vine is large-leaved, suitable for screening and producing dense shade. It bears small racemes of rosy purple, pea-shaped blossoms toward the close of August. Pkt. 10 cts.; 1/4 oz. 30 cts.

\section{Lathyrus latifolius - Everlasting Pea}

The flowers resemble Sweet Peas and are showy but not fragrant. They thrive in any good soil, are fine for low trellises and posts, and bloom all summer. Ht. $6 \mathrm{ft}$.

Giant White Pearl and Giant Pink Beauty. Very desirable for cut flowers. Each, pkt. 15 cts.; $1 / 4 \mathrm{oz}$. 40 cts.

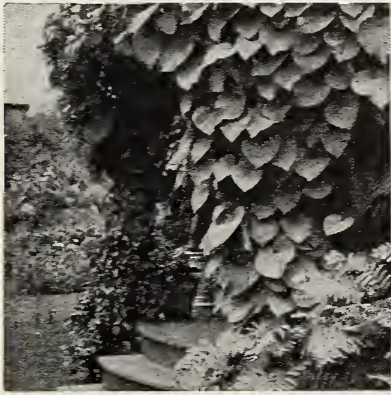

Aristolochia sipho

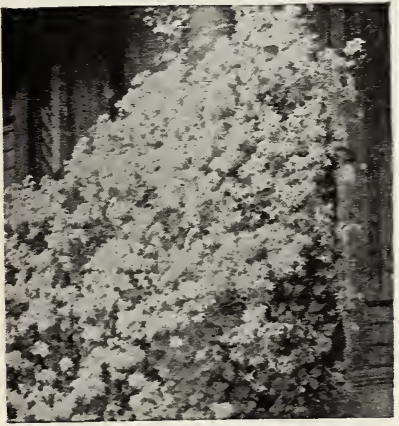

Clematis paniculata

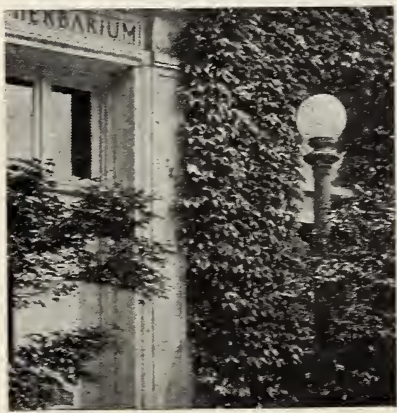

Ampelopsis Veitchi 


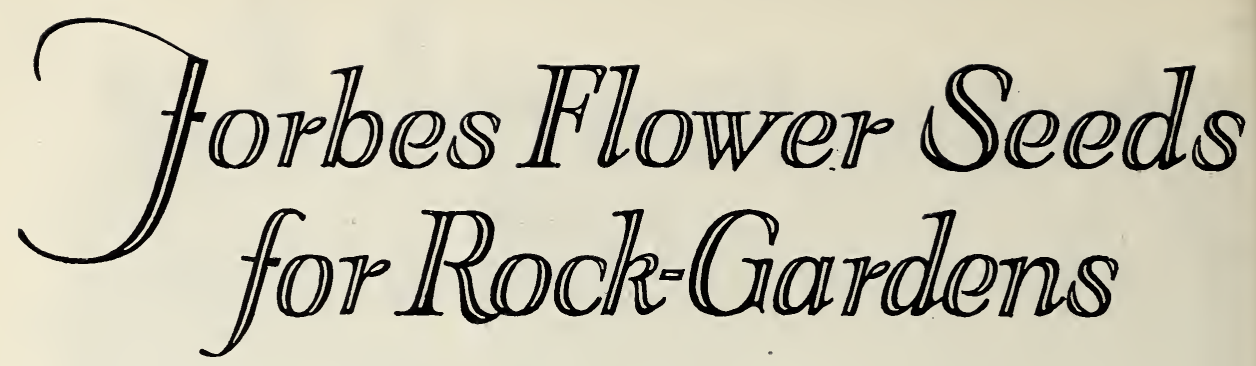

We know of nothing in flower-culture more interesting than the planning and development of a rock-garden. In most of our gardens there is opportunity for one, however small. It requires little room and slight care, and provides unusual garden joy. A terrace difficult to keep in lawn, a steep bank alongside a driveway, or an old building foundation will serve as a location, or the rock-garden may be built up above the garden level. The plants suited to rock-gardens have a peculiar charm. Each serves its purpose--as a groundcover, as a crevice plant, as a trailer to hang over rock ledges, as a taller background plant, or as an accent of color. Many rock-plants may easily be raised from seed. Of those shown below, all are hardy, some are quite rare, and many have unusual interest.

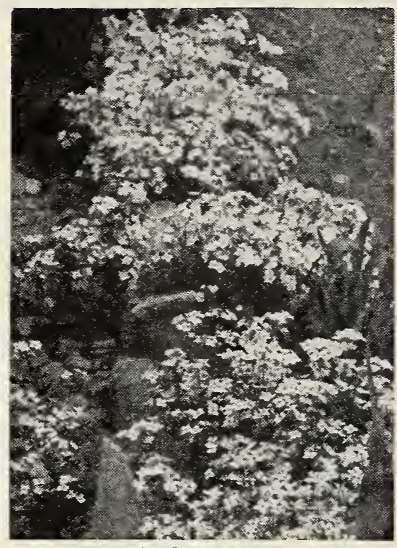

Arabis alpina

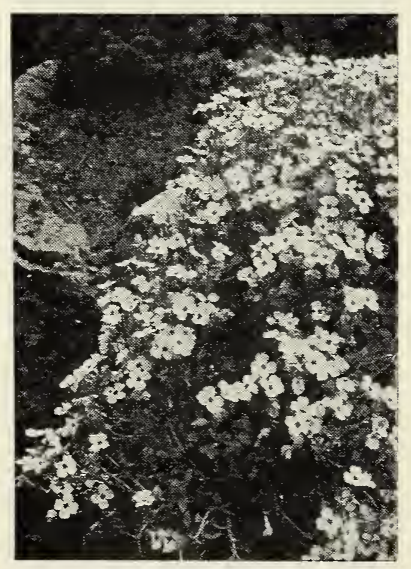

Aubrietia deltoidea
Alyssum saxatile compactum (Basket of GoId). Small, bright yellow flowers in April and May. Ht. 12 in. Pkt. 15 cts.

Anemone PuIsatilla (Pasque Flower). Lovely blue and Iilac flowers held above the finely cut, grey-green foliage during April and May. Ht. 12 in. Pkt. 25 cts.

Aquilegia alpina (AIpine Columbine). A rare variety with powdery blue flowers in May. Ht. 12 in. Pkt. 15 cts.

Arabis alpina (Rock Cress). The foliage forms a dense carpet which is completely covered with smaIl white flowers in May. Ht. 6 in. Pkt. 10 cts.

Arenaria montana (Sandwort). This dwarf, trailing foliage forms a green mat and bears small, white, starry flowers in May and June. Ht. 5 in. Pkt. 25 cts.

Armeria Laucheana (Sea Thrift). SmaII, rose-crimson, globular flowers borne on stems above a cushion of grass-like leaves from June to August. Ht. 6 in. Pkt. 25 cts.

Aster alpinus (Blue Mountain Daisy). Compact plants with blue-lavender, daisy-like flowers from June to September. Ht. 10 in. Pkt. 25 cts.

Aster subcæruleus (Lilac AIpine Aster). Bright mauve, daisylike flowers in June and July on dwarf plants. Likes a sunny location. Ht. 12 in. Pkt. 25 cts.

Aubrietia deltoidea graeca (FaIse WaII Cress). Low, carpetlike plants, covered with dark violet flowers in April and May. Ht. 6 in. Pkt. 25 cts.

Aubrietia deltoidea Moerheimi (Rose Wall Cress). Dense mats of foliage, bearing many deep rose-colored flowers in April and May. Ht. 6 in. Pkt. 50 cts.

Campanula carpatica alba (White Carpathian HarebelI). SmalI, white, bell-shaped flowers throughout the summer. Ht. 6 in. Pkt. 15 cts.

Campanula carpatica, Blue (Blue Carpathian HarebeII). Free-flowering, hardy plants continuing in bloom the whole season. Ht. 6 in. Pkt. 15 cts.

Cerastium tomentosum (Snow-in-Summer). Grey-foliaged trailing plants covered with delicate white flowers in May and June. Likes dry sunny spot. Ht. 6 in. Pkt. $15 \mathrm{cts}$.

Chelone Torreyi (Turtlehead). Beautiful, tubular-shaped, coral-pink flowers blooming profusely from July to October. Fine for backgrounds. Ht. $3 \mathrm{ft}$. Pkt. $15 \mathrm{cts}$.

Delphinium, Tom Thumb (Baby Larkspur). Short, strong spikes of ultramarine-blue flowers from June to October. Ht. 12 in. Pkt. 25 cts.

Dianthus Allwoodi alpinus. Small, Dianthus-like flowers in purple, pink, white, and rose shades. Ht. 4 in. Pkt. 50 cts.

Dianthus deltoides (Maiden Pink). Beautiful, single, coralpink flowers with dark eyes above grey foliage in June and July. Ht. 8 in. Pkt. 25 cts. 


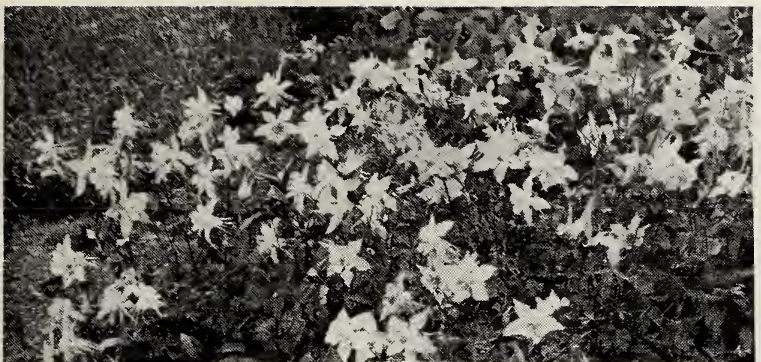

Aquilegia alpina

Edelweiss (True) (Leontopodium alpinum). A Swiss alpine with downy white leaves and horned flowers, having yellow knotted centers, in June and July. Ht. 5 in. Pkt. 25 cts.

Geum, Lady Stratheden. Attractive, double yellow flowers on long stems above a rosette of base leaves. Blooms from June to September. Ht. $2 \mathrm{ft}$. Pkt. $25 \mathrm{cts}$.

Geum, Mrs. Bradshaw. Similar to the above, but with dark orange-scarlet, double flowers. June to September. Ht. $2 \mathrm{ft}$. Pkt. $25 \mathrm{cts}$.

Gypsophila repens (Dwarf Baby's Breath). Trailing, light grey foliage with small white or pale rose flowers in June and July. Ht. 6 in. Pkt. 25 cts.

Helianthemum vulgare mutabile (Rock Rose). A shrubby evergreen for sunny locations with single and semi-double rose to white flowers in June and July. Ht. 10 in. Pkt. 15c.

Heuchera sanguinea splendens (Coral Bells). Beautiful coralpink bells, gracefully held on slender stems above a whorl of leaves from May to September. Ht. $2 \mathrm{ft}$. Pkt. $25 \mathrm{cts}$.

Iberis gibraltarica (Perennial Candytuft). Lavender-pink flowers shaded white, in June and July. Ht. 8 in. Pkt. 15c.

Iberis sempervirens (Perennial Candytuft). Cushions of Evergreen foliage with profuse white bloom from April to June. Prefers a sunny location. Ht. 8 in. Pkt. 25 cts.

Incarvillea grandiflora (Fairy 'Trumpets). Clusters of large, rose, trumpet-like flowers on long stems above the fern-like foliage in June and July. Likes sun. Ht. $2 \mathrm{ft}$. Pkt. $50 \mathrm{cts}$.

Linum perenne, Blue (Blue Flax). Hardy plants with fine foliage and deep blue flowers on delicate stems from May to August. Ht. $11 / 2 \mathrm{ft}$. Pkt. $10 \mathrm{cts}$.

Lychnis Haageana Hybrids. Orange, scarlet, and crimson, 2-inch flowers, in May and June. Ht. $1 \mathrm{ft}$. Pkt. $15 \mathrm{cts}$.

Lychnis viscaria splendens (German Catchfly). Evergreen foliage with fragrant, rose-pink and crimson flowers, like double pinks, in May and June. Ht. $1 \mathrm{ft}$. Pkt. $15 \mathrm{cts}$.

Myosotis palustris (True Forget-me-not). Dainty, small, pale blue flowers on dwarf, bushy plants from June to October. Ht. 8 in. Pkt. 20 cts.

Nepeta Mussini (Caucasian Catmint). Tiny bue Iavender spikes blooming from April to June. Ht. 8 in. Pkt. 25 cts.

Enothera missouriensis (Evening Rock Primrose). Large, golden yellow flowers on trailing stems from June to August. Ht. 10 in. Pkt. 25 cts.

Platycodon Mariesi (Dwarf Balloon Flower). Deep blue, starshaped bells on erect stems in June. Ht. $1 \mathrm{ft}$. Pkt. $15 \mathrm{cts}$

Poppy, Sunbeam Bouquet (Papaver nudicaule Hybrids). A new strain of the Iceland Poppy in tones of rose, maize, and cream. Blooms June to September. Ht. $1 \mathrm{ft}$. Pkt. $25 \mathrm{cts}$.

Primula auricula (Laced Primrose). Brilliant maroon, crimson, yellow and purple flowers in umbels in April and May. Ht. 6 in. Pkt. 25 cts.

Primula cashmeriana (Cashmerian Primrose). Early-flowering hybrids with large heads of white, mauve, purple, and violet flowers in April and May. Ht. 12 in. Pkt. 50 cts.

Primula officinalis Hybrids (Blue and White Cowslips). Fragrant bright blue and white flowers in April and May. Ht. 8 in. Pkt. 25 cts.

Primula veris (Cowslip). Fragrant sulphur-yellow flowers on dwarf plants in April and May. Ht. 8 in. Pkt. 25 cts.

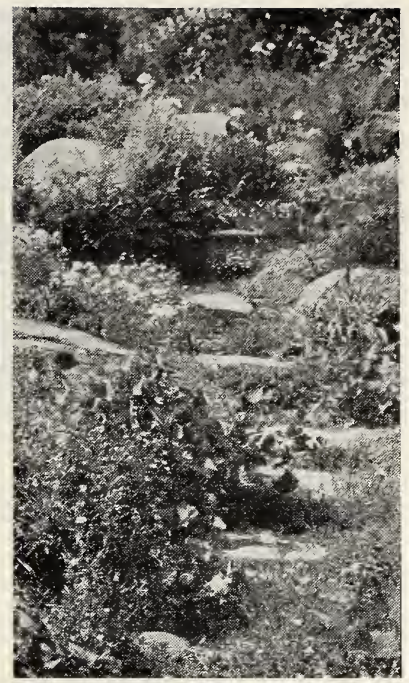

A pretty rockery

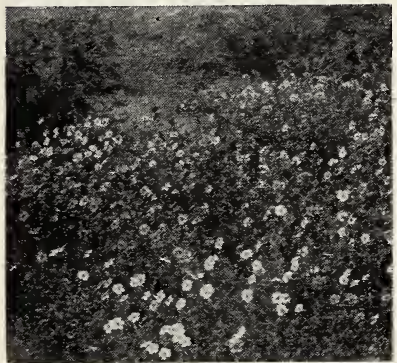

Helianthemum mutabile

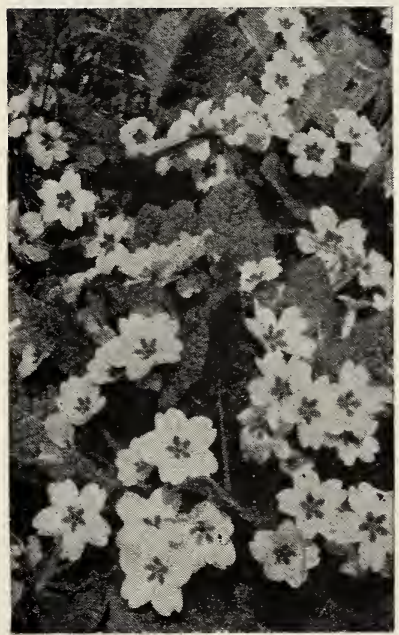

Primula veris 


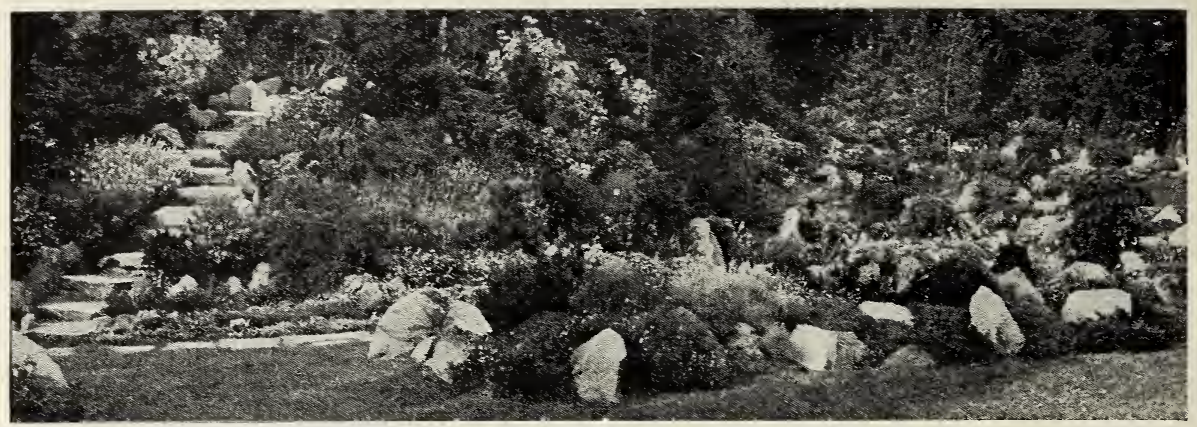

This delightful Rock-Garden holds hundreds of charming little plants

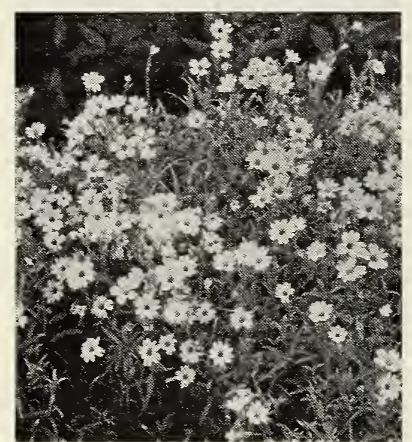

Cerastium tomentosum. See page 82

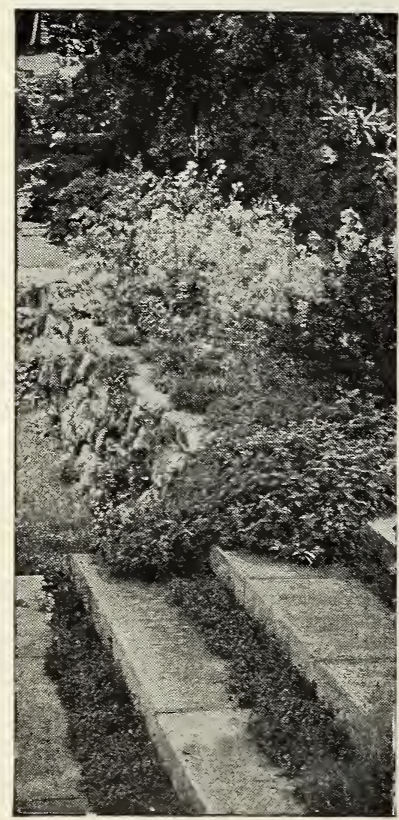

Veronica repens on steps
Primula vulgaris (English Primrose). Fragrant, pale yellow flowers in April and May. Ht. 9 in. Pkt. 25 cts.

Santolina tomentosum (Lavender Cotton). A very finely cut lavender-grey-foliaged evergreen plant with miniature yellow flowers in July and August. Ht. $11 / 2 \mathrm{ft}$. Pkt. $25 \mathrm{cts}$.

Saponaria ocymoides (Rock Soapwort). Grey foliage; sheets of crimson flowers in May and June. Ht. $1 \mathrm{ft}$. Pkt. 15 cts.

Saxifraga decipiens grandiflora (Rockfoil). An original alpine plant with a massing of charming white flowers in April and May. Ht. $11 / 2 \mathrm{ft}$. Pkt. $35 \mathrm{cts}$.

Saxifraga, Species Mixed (Mixed Rockfoil). Alpine varieties in white, rose, carmine and purple, blooming in April and May. Ht. $1 \mathrm{ft}$. Pkt. 25 cts.

Sedum acre (Golden Moss). Grey, fleshy leaves with bright yellow flowers from May to July. Ht. 3 in. Pkt. 25 cts.

Sedum anglicum (White and Pink Stonecrop). Fleshy, greyleaved plants with white and pink flowers in April and May. Ht. 4 in. Pkt. 25 cts.

Sedum, Fabaria (Rose Stonecrop). Rose-colored blooms in April and May on fleshy plants. Ht. 4 in. Pkt. 25 cts.

Sempervivum, Mixed (Houseleek). An assortment of hardy plants with fleshy rosettes of green and bronze leaves. Ht. 6 to 12 in. Pkt. 25 cts.

Veronica prostrata (SpeedweII). Dwarf species with spikes of deep bue flowers in June and JuIy. Ht. 6 in. Pkt. 25 cts.

Veronica repens (Trailing Speedwell). Dwarf plants of trailing habit bearing blue and white flowers from April to June. Ht. 3 in. Pkt. 25 cts.

Viola cornuta, Admirabilis (Johnny Jump-up). Compact, free-flowering plants with dark-blotched purple flowers throughout the season Ht. 6 in. Pkt. $25 \mathrm{cts}$.

COLLECTION OF SEEDS OF ALPINE AND ROCK-PLANTS: One pkt. each of the above 50 varieties (if bought separately would total $\$ 12.05$ ) for $\$ 10$.

The perennial seeds we offer in the above list will easily produce Alpine and Rock-Plants the first season, if started early indoors, or if sown outdoors in July will produce strong plants the following spring. For a more complete list of plants of rare and popular varieties, see the Rock-Plant List we offer in our Plant Catalogue.

\section{Rock-Garden Books}

Alpen Flowers. By L. and C. Schröeter. A very useful book for the identification of Alpines. Over 200 fine color illustrations. 26 plates. $\$ 3$ postpaid.

A Simple Guide to Rock-Gardening. By Sir J. L. Cotter. A practical book of rock, wall, and bog-garden making, giving methods and choice of planting material, as well as its culture. $126 \mathrm{pp}$. $\$ 1$ postpaid. 

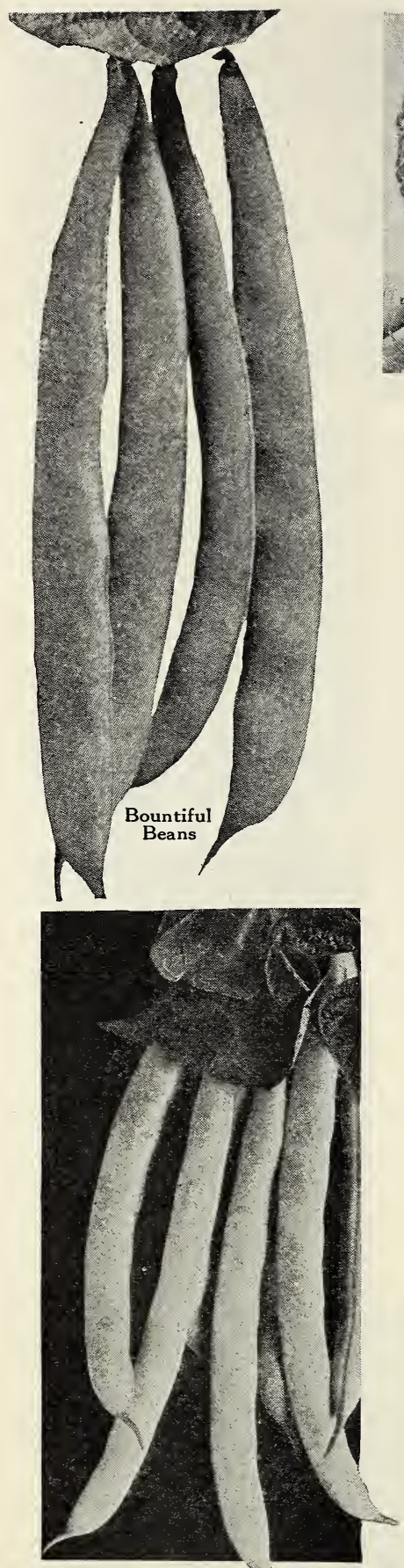

Unrivaled Wax Beans

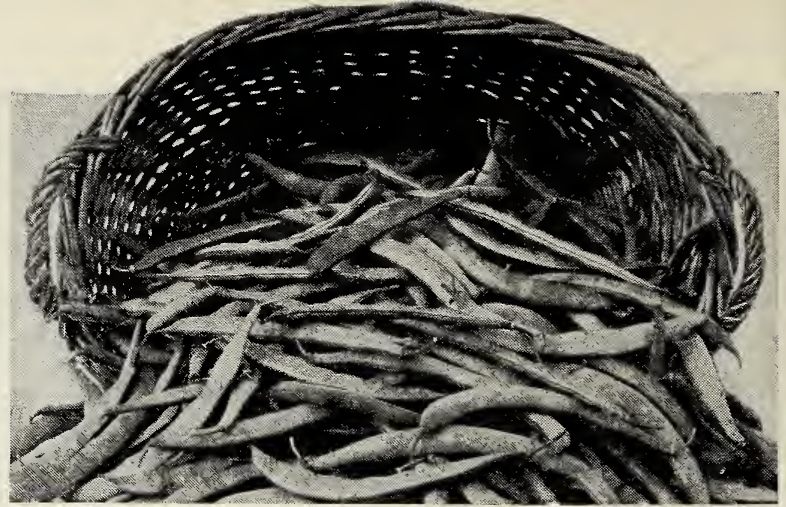

\section{Dwarf Beans}

One pound will plant 100 feet of row

The best soil is a well-manured sandy loam, but very fine crops are produced on an average garden soil. After the ground is perfectly warm (usually about May 1) sow at intervals of two weeks in order to secure a succession throughout the season. Sow 2 inches deep, 3 inches apart in rows 2 feet apart and cover firmly. Cultivate often, keeping a mulch of loose soil at all times. Deep cultivation after flowering will cause many blooms to fall. Beans will be ready in 6 to 8 weeks.

Bountiful. This is the best flat-podded, green variety. The light green pods are $61 / 2$ to 7 inches long, stout, flat, somewhat curved, absolutely stringless, and of very fine quality. It is very early, and a heavy yielder. Pkt. $10 \mathrm{cts}$; $1 / 2 \mathrm{Ib}$. 30 cts.; Ib. 50 cts.; 2 Ibs. 95 cts.; 5 Ibs. \$2.25.

Burpee's Stringless. Very early, productive and hardy. The pods average about 5 inches long, are straight, round, crease-backed, and of a dark green color. They are tender, brittle, of the finest flavor and quality, and strictly stringless. The plants are medium Iarge, with dark green foliage. Pkt. 10 cts.; $1 / 2$ Ib. 30 cts.; Ib. 50 cts.; 2 Ibs. 95 cts.; 5 Ibs. $\$ 2.25$.

Dwarf Horticultural. This is used as a Shell Bean. It is stringless, of good flavor, with pods slightly curved, 5 inches long, of greenish yellow speckled carmine. Pkt. $10 \mathrm{cts}$; $1 / 2 \mathrm{Ib}$. 25 cts.; lb. 45 cts.; 2 lbs. 85 cts.; 5 Ibs. $\$ 2$.

Sure-Crop Wax. This is stringless, hardy, and rust-resisting. The pods average $61 / 2$ inches Iong, are thick, semi-flat, and of a clear yellow color. The plant-growth is strong. Pkt. 10 cts.; $1 / 2$ Ib. 30 cts.; lb. 50 cts.; 2 Ibs. 95 cts.; 5 Ibs. $\$ 2.25$.

Unrivaled Wax. This one has a small plant, is very early, and bears enormous crop of translucent pale yellow pods about $51 / 2$ inches Iong, somewhat curved, semi-flat, rather slim, but fleshy, and of the finest texture and tenderness. Pkt. 10 cts.; 1/2Ib. 30 cts.; Ib. 50 cts.; 2 Ibs. 95 cts.; 5 Ibs. $\$ 2.25$.

\section{Bush Lima Beans}

One pound will plant about 100 hills, or 100 feet of row

A rich, light soil is best. Sow the seed after the ground is dry, danger of frost is over, and the nights are warm (about May 20). Make the rows 3 feet apart, dropping the Beans so the plants will stand 4 to 6 inches apart in the row, and cover with less than 1 inch of soil. The Beans will germinate more rapidly if placed on edge with the eye down.

Forbes Ideal Potato Bush Lima. The plant is $11 / 2$ feet high, and carries a very heavy crop of large, stout pods, usually with four, round, thick Beans to the pod. It is the best for the home-garden. Pkt. 15 cts.; 1/2 Ib. 30 cts.; Ib. 50 cts.; 2 Ibs. 95 cts.; 5 Ibs. $\$ 2.25$.

Fordhook Bush Lima. The green Beans are thick and meaty, four to the pod, very tender, and juicy. Bears the large pods in clusters and is a heavy yielder. Pkt. $15 \mathrm{cts}$; $1 / 2 \mathrm{Ib}$. 30 cts.; Ib. 50 cts.; 2 Ibs. 95 cts.; 5 Ibs. $\$ 2.25$. 


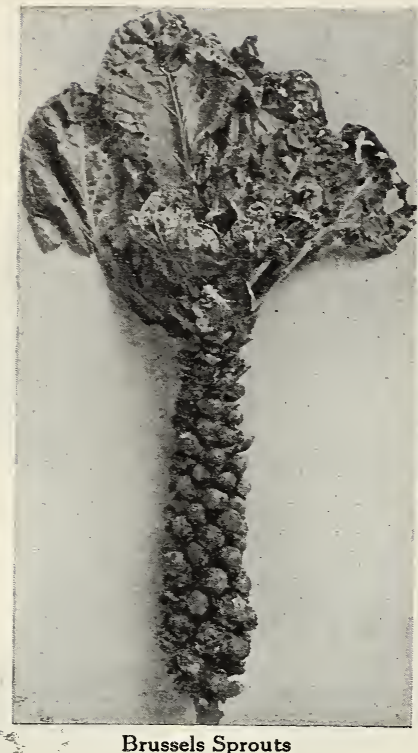

Broccoli has suddenly become a very popular vegetable in great demand in almost every market. It has long been a standby of experienced gardeners who have grown it instead of cauliflower in the hot summer months.

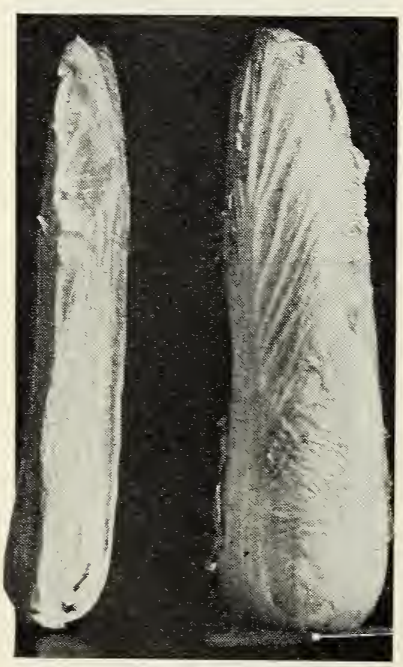

Narrow Head Chinese Cabbage

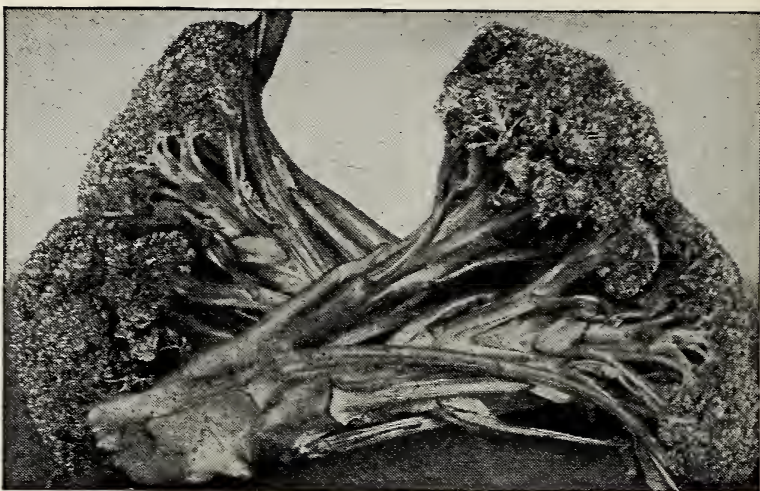

Italian Green Sprouting Broccoli

\section{Broccoli}

This is closely allied to the Cauliflower but is generally considered more hardy. In growing Broccoli, a seed-bed should be prepared and the seed sown in May. The plants will be ready to transplant late in June or early in July, and should be set in very rich, mellow soil, in rows about $21 / 2$ feet apart, leaving $11 / 2$ feet between the plants.

Italian Green Sprouting. This is a distinct variety. The plant forms a large, solid head which remains green, and after this head is cut out, a number of sprouts develop from the leaf-axes, each terminating in a small head 1 inch in diameter. Pkt. 25 cts.; 1/4 oz. \$1; 1/2oz. \$1.85; oz. \$3.50.

\section{Brussels Sprouts}

\section{One ounce will produce 1,500 plants}

Use a rich, heavy loam with good drainage. Sow outside in rows in May and transplant in July to rows $21 / 2$ feet apart, setting the plants $11 / 2$ feet apart in the rows. Cultivate often. They are hardy and keep in fine condition from October until December, while farther south they keep through March.

Long Island Grown Half-Dwarf Improved. Very uniform, producing frrm, dark green sprouts. The plants are dwarf, compact, and hardy. Pkt. 25 cts.; oz. \$1.25; 1/4 Ib. $\$ 4.50$.

\section{Cardoon}

A vegetable that is grown somewhat like celery and served after the manner of asparagus. Sow in the open ground in May, and thin or transplant the seedlings so that they stand $2 \frac{1}{2}$ feet, one from the other, in rows 4 feet apart. A catchcrop, such as beans, lettuce, or beets, may be taken between the rows. At the end of the summer, and two to three weeks before using, it is necessary to blanch the Cardoons. The heads of the plants are tied together, straw is piled against them, and the surrounding soil is then heaped up against the straw. Pkt. 10 cts.; oz. 50 cts.; $1 / 4$ Ib. $\$ 1.50$.

\section{Chinese Cabbage}

We advise that the seed of this Cabbage be sown in July or August (not earlier) because it has a tendency to bolt to seed in warm weather. Either start in frames and transplant, or, sow where the plants are to remain, in rows $21 / 2$ feet apart, thinning to from 12 to 18 inches apart in the row. It is very easily grown and takes very little space.

Special Narrow Head. This strain forms tall, slim, pointed heads, much heavier and taller than any other variety and very solid. The flavor is very delicate. Pkt. $15 \mathrm{cts}$; $1 / 2 \mathrm{oz}$. 50 cts.; oz. 90 cts.; $1 / 4 \mathrm{Ib}$. $\$ 3$. 


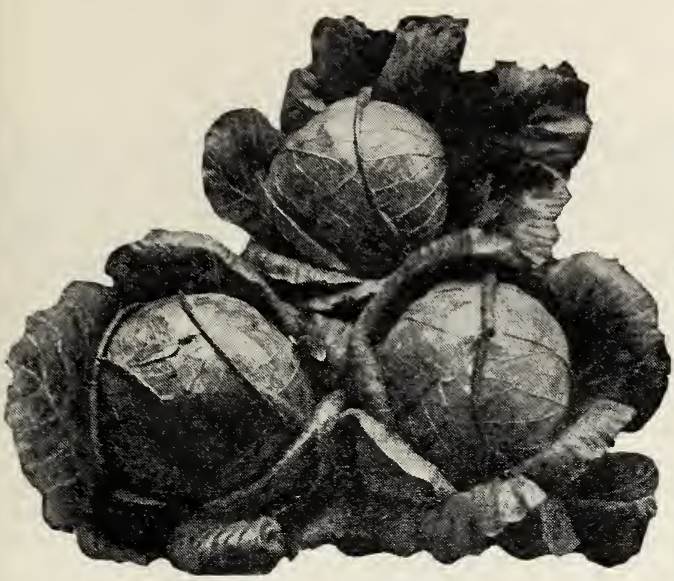

Golden Acre Cabbage

\section{Cabbage}

One ounce will produce 1,500 plants

A well-drained, heavy Ioam soil gives best results. Sow the early varieties about September 15 , and in four to frve weeks transplant to coldframes, where the plants can be wintered over. Set plants down to the first leaf, burying all the stem. The common method is to sow the early varieties in hotbeds in February. From March 15 to April 15, set out plants in open ground, 15 to 18 inches apart in rows which are 2 to $2 \frac{1}{2}$ feet apart. This earliest crop matures in June. For secondearlies, sow April 1 and plant out in May, 11/2 feet apart, leaving $21 / 2$ feet between rows, the crop maturing in July and August. For late Cabbage, sow from May to June, setting the plants out in July, $11 / 2$ to 2 feet apart in rows $21 / 2$ to 3 feet apart. Crop matures from September to November.

Copenhagen Market. The round, solid heads weigh 8 to

10 pounds each, are of fine quality, and very uniform, the light green. leaves folding tightly and compactly over one another. Almost as early as Early Jersey Wakefield. Pkt. 15 cts.; $1 / 2$ oz. 40 cts.; oz. 75 cts.; $1 / 4 \mathrm{lb}$. $\$ 2.50$.

Danish Roundhead, Short-stemmed. We consider this cne of the best-keeping varieties ever originated. Heads are round, Iarge, heavy, extremely hard, and mature late. Pkt. 15 cts.; $1 / 2$ oz. 35 cts.; oz. 60 cts.; $1 / 4 \mathrm{lb}$. $\$ 2$.

Early Jersey Wakefield. This excellent, extra-early, pointedhead sort is without a parallel. The heads are medium-sized, but are solid and extremely uniform in both green color and size. Pkt. 15 cts.; 1/2oz. 30 cts.; oz. 50 cts.; 1/4Ib. $\$ 1.50$.

Golden Acre. A variety which closely resembles Copenhagen Market, but maturing eight to ten days earlier. Because it is smaller it can be planted closer. It is earlier and of finer quality than any other round-headed Cabbage. Pkt. 25 cts.; $1 / 2$ oz. 80 cts.; oz. $\$ 1.50 ; 1 / 4$ Ib. $\$ 5.50$.

Late Flat Dutch, Superb. The heads grow very large and flat, of a bluish green color, with few outer leaves and mature quite late. They are uniform, solid, and of fine quality. Pkt. 15 cts.; $1 / 2$ oz. 30 cts.; oz. 50 cts.; 1/4Ib. $\$ 1.50$.

Mammoth Rock Red. This Iate standard variety produces very solid, 10-pound heads of intense dark red color. The plant is large, with numerous spreading leaves and is sureheading. Used very largely for pickling on account of its excellent flavor and attractive color. Pkt. 15 cts.; 1/20z. 35 cts.; oz. 60 cts.; 1/4 Ib. $\$ 2$.

Perfection Drumhead Savoy. This is the hardest-heading, most satisfactory, and best all-round Savoy Cabbage. The plants are of strong growth, having only a few outer leaves growing closely about the large, solid, round, dark green heads. The leaves are heavily savoyed and the flavor is mild. Pkt. 15 cts.; $1 / 2$ oz. 35 cts.; oz. 60 cts.; $1 / 4 \mathrm{Ib} . \$ 2$.
The most delicious of all Cabbages, and perhaps all vegetables, is Early Jersey Wakefield taken young, boiled in salted water until tender, drained, then served with Iumps of butter. Cauliflower and broccoli are coarse and common in comparison.

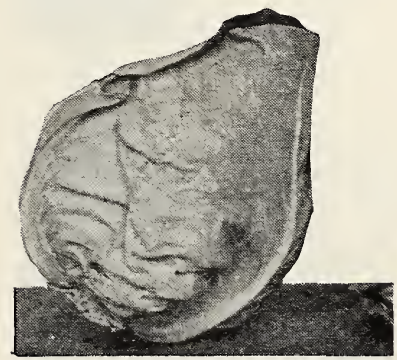

Early Jersey Wakefield Cabbage

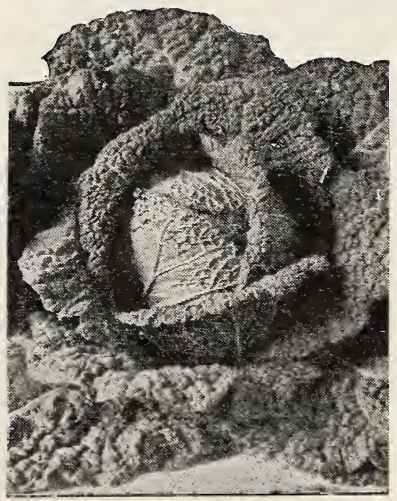

Drumhead Savoy Cabbage 


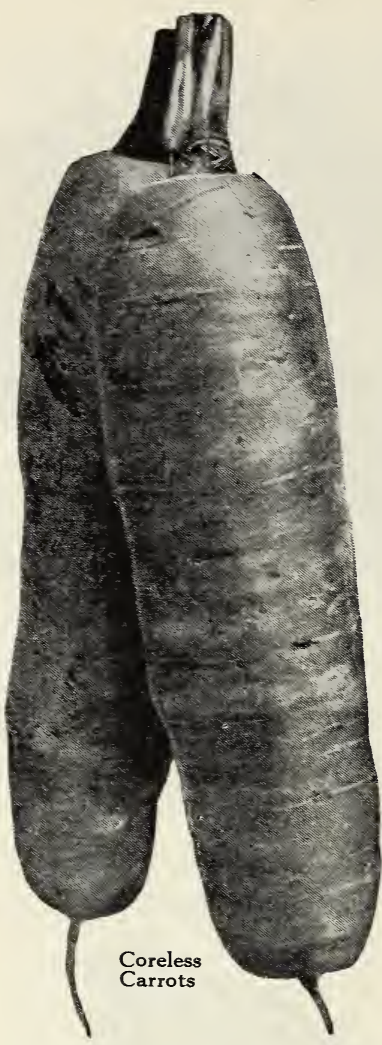

Carrots are colorfuI and delicious vegetables, full of health-giving elements. They figure largely in special diets. Excellent when cooked with peas.

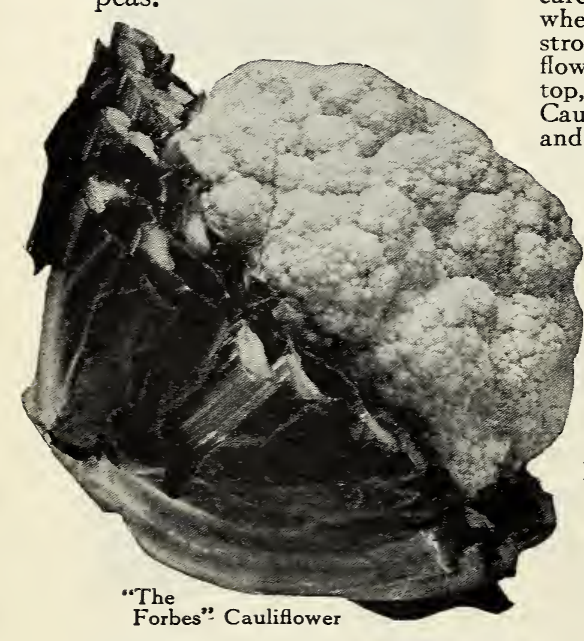

\section{Carrots}

One ounce will sow 100 feet of row

Carrots give satisfactory results when sown in any good garden soil, if thoroughly and deeply worked; a sandy loam, well-manured, is the most desirable. For early crop, sow as early as the ground can be worked and for later crops, sow up to about June 15 . Sow in rows 12 to 14 inches apart and cover with about $1 / 2$ inch of soil. As soon as plants appear, use cultivator or wheel-hoe. When of sufficient size, thin out the plants to stand 2 to 3 inches between plants.

Chantenay Half-Long. A medium-early, half-Iong, smooth, blunt-rooted sort of deep orange-red color and delicate flavor. As it has a nice top, it is very popular for frame use, allowing close planting. The root, broadest at shoulder, tapering toward base, and running suddenly to a point, is 6 inches long. Pkt. 10 cts.; oz. 20 cts.; 1/4 Ib. 60 cts.; Ib. \$2.

Coreless. A half-long, cylindrical blunt-pointed variety with a very small taproot and small, fine top. The shape and size are extremely uniform, averaging 6 to 7 inches in length and $11 / 2$ inches in diameter, clean-skinned, smooth, and easily pulled. The flesh is very fine-grained, absolutely without any woody heart or core, and entirely free from stringiness and coarseness. The red-orange flesh is of the finest flavor. Pkt. 10 cts.; oz. 30 cts.; $1 / 4 \mathrm{lb}$. 85 cts.; lb. $\$ 3$.

Danvers Half-Long. This sort is slightly Ionger than Chantenay, growing 7 to 8 inches long, is square-shouldered, tapering gradually to a blunt point. The root is smooth, of an orange-red color, with sweet, crisp flesh. For main planting it has no superior, and when sown during June, it produces the best roots to store for winter. Pkt. 10 cts.; oz. 20 cts.; $1 / 4$ Ib. 60 cts.; Ib. $\$ 2$.

French Forcing. The earliest variety of Carrot, but is almost round. The flesh is a reddish orange and the quality is excellent. Pkt. 10 cts.; oz. 30 cts.; $1 / 4$ lb. 85 cts.; lb. \$3.

\section{Cauliflower}

\section{One ounce will produce 1,000 plants}

Cauliflower will not grow well during hot weather. For early spring crop, seed should be sown in a hotbed, or coldframe, during February, never Iater than March 10. The plants may be set out like cabbage, right after frost has gone; these will head during June. For a fall crop the seed is sown about May 20. Plants may be set out July 15. With good care, they will grow slowly until the cool nights of September, when they develop rapidly into strong, leafy plants, and a strong plant nearly always produces a good flower. As the flowers form, gather the leaves together and tie them at the top, to blanch heads and prevent injury from sun and frost. Cauliflower requires rich, well-drained soil, plenty of moisture, and only a moderately high temperature.

"The Forbes." Best for early and Iate crops. A Cauliflower of the Snowball type, but as the crop heads up practically all at one time, make plantings in succession. It excels others for vigor and freedom from disease, and produces first-grade heads, even under adverse growing conditions. The inner leaves wrap tightly over the head from its beginning up to 4 inches diameter, when the heads should be tied up. A few days of favorable growing weather quickly increase the size to 10 to 11 inches diameter. The heads are very deep, with pure white, solid, rounded curds and mature very early. Pkt. $50 \mathrm{cts}$.; $1 / 8 \mathrm{oz}$. $\$ 1.25 ; 1 / 4 \mathrm{oz}$. \$2;. oz. \$6.

Forbes Catskill-Snowball. We recommend this as the premier variety for outdoor culture on account of its earliness, vigorous growth, handsome appearance and high quality. Its strong, vigorous, constitution enables it to withstand weather conditions that make Cauliflower culture somewhat of a gamble. Pkt. 25 cts.; $1 / 8$ oz. 85 cts.; $1 / 4$ oz. \$1.50; oz. \$5. 


\section{Celery}

One ounce will produce about 4,000 plants

For an early supply, sow seeds of early or self-blanching varieties in flats any time during February. Cover with sand and keep constantly moist. When young seedlings are big enough to be handled, transplant into other flats, 2 to 3 inches apart each way.

Harden gradually and by middle of April set out plants in the garden in rows 3 feet apart, 8 inches apart in the row. Cultivate freely and water abundantly. The plants should give you Celery beginning middle of October and up to Christmas time. For a later supply, start seeds of winter-keeping varieties in a hotbed about middle of March to April 1. Transplant as above and plant out into the garden about June 1, setting the plants 2 feet apart. To blanch gradually, hill up the stalks, or boards pushed up against the row on both sides will serve the purpose. As cold weather approaches, hill more or mulch with leaves. For winter storage, dig up the plants with the roots and place upright in well-protected frames or store in a cool cellar, packed quite closely.

Giant Pascal (Special Strain). This is vigorous, compact, and productive, and is splendid for fall and winter use. It has short, dark green leaves; stalks of medium height, which are very thick, nearly round but broadening toward base. It blanches yellowish white, is solid, crisp and tender, and a fine keeper. Pkt. 15 cts.; 1/4oz. 40 cts.; oz. \$1.25.

Golden Plume. This closely resembles the old Golden Selfblanching in crispness and flavor, but is distinctly larger and ranker in growth, more plainly ribbed, blanches more quickly, matures rather earlier, and shows less tendency to blight or crown-rot. It shows the large full-plumed center so much desired. Pkt. 25 cts.; $1 / 4$ oz. $\$ 1.50$; oz. $\$ 4$.

Golden Self-blanching (Dwarf Strain). Our stock of this famous variety, long a standard for early use, is unsurpassed. The plants produced by our seed are compact and stocky, with yellowish green foliage turning to golden yellow with a slight earthing up. Stalks are ivory-white, very thick, broad, solid, crisp and of fine flavor. This is a big-hearted strain, with no hollow stalks, even and free from green-top. Pkt. 25 cts.; $1 / 4$ oz. 60 cts.; oz. $\$ 1.50$.

Newark Market. The plant is somewhat taller than Golden Self-blanching, the foliage is broader, and the stalks are higher jointed, heavier, and more plainly ribbed. Its stalks are easily blanched, by boarding, in from two to three weeks' time. On account of the greater stalk-length and the compact foliage, the stalks blanch much higher up than does the Golden Self-blanching. Newark Market develops very rapidly and produces large, thick, fleshy stalks of great solidity, very brittle, crisp, and of fine flavor. Pkt. 25 cts., $1 / 4$ oz. 75 cts.; oz. $\$ 2$.

Celery for Soup Greens. A Ioose-growing type from which stalks may be cut continuously. Merely grow in good soil kept free from weeds; do not earth or blanch. Pkt. 10 cts., oz. 35 cts.; $1 / 4$ Ib. $\$ 1$.

\section{Celeriac (Turnip-rooted Celery)}

\section{One-fourth ounce will sow 100 feet of row}

Use a rich, moist soil and sow about April 20, covering the seed with about $1 / 2$ inch of soil, frrming it down well. Thin the seedlings out to about 1 inch apart in the row, transplant into rows 2 feet apart, placing the plants about 5 inches apart in the row. Give thorough cultivation. Use when roots are 2 inches in diameter.

Large Smooth Dwarf Moonarchie. Produces Iarge, smooth roots of fine quality which are used as a flavoring or eaten as a salad. The "knob" will grow larger if the outer leaves are pulled and used for soup greens. This strain is finegrained, free from side roots, and has a short top. Pkt. 10 cts.; $1 / 2$ oz. 40 cts.; $1 / 4$ Ib. $\$ 2.50$.

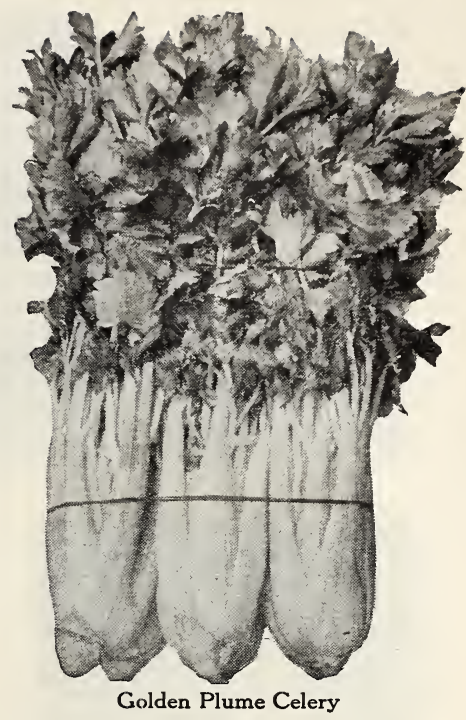

Late Celery is a good crop to plant on the same ground upon which grew early peas, radishes, lettuce, etc., after they have been used.

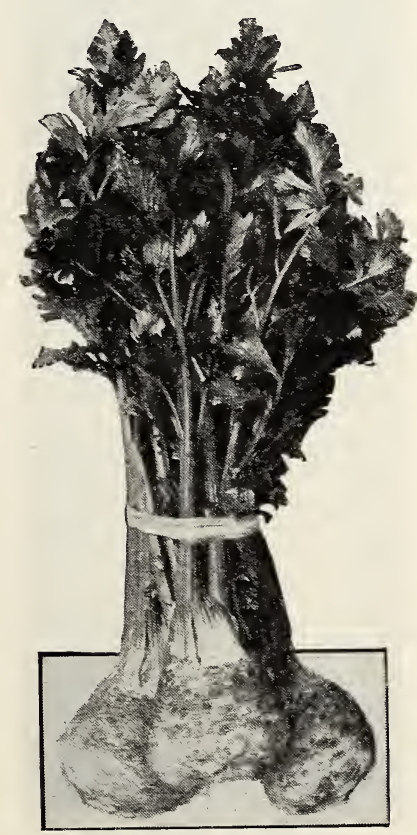

Moonarchie Celeriac 


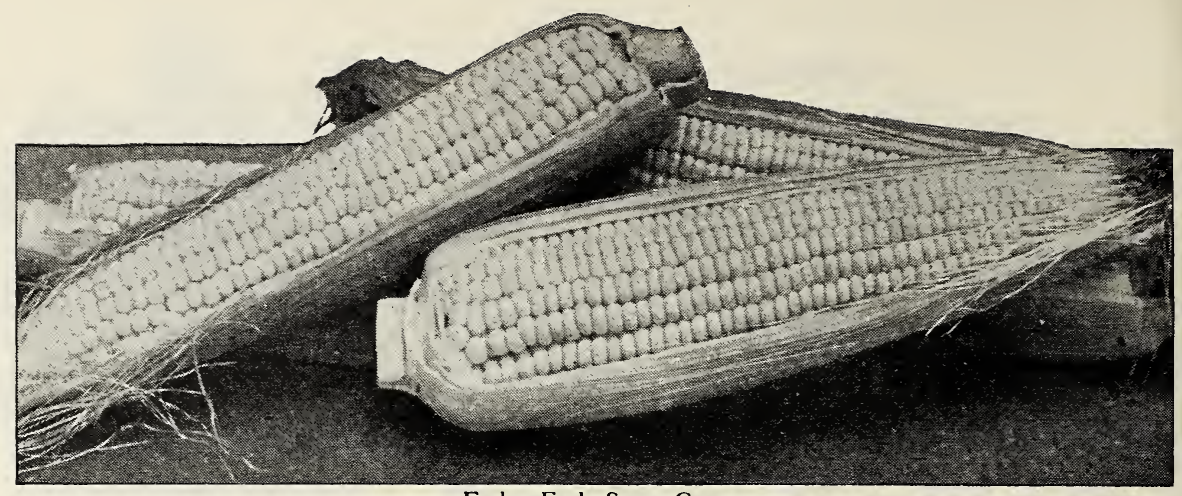

Forbes Early Sweet Corn

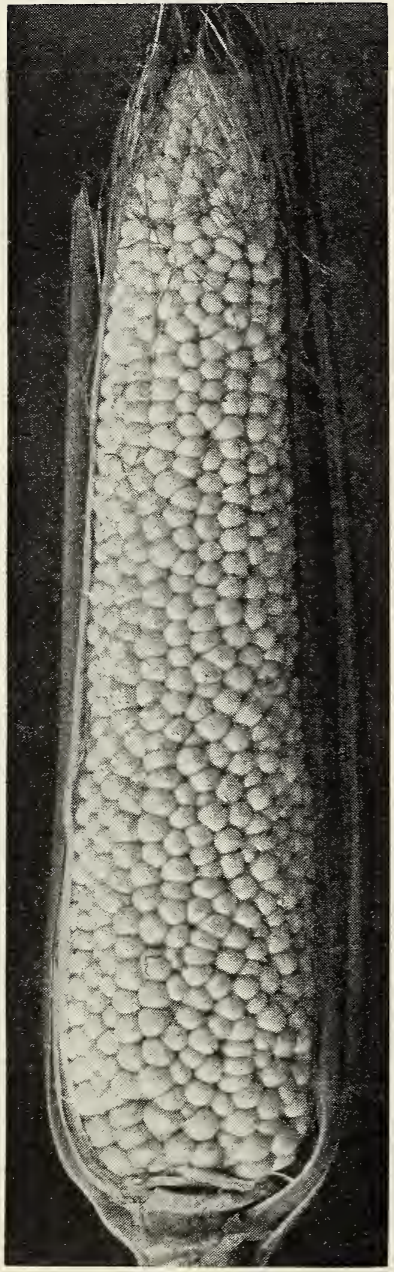

Country Gentleman Sweet Corn

\section{Chicory}

One ounce will plant 100 feet of row

Large-rooted or Coffee. The soil should be light and rich. Sow seed about May 1 in rows 2 to $21 / 2$ feet apart, and cover firmly with $1 / 2$ inch of soil. Thin to 6 inches apart and cultivate well. The roots will be ready to dig in the fall and when dried are used as an adulterant for coffee. Plant grows large leaves and thick stalks. The young leaves sprouted from one-year-old roots are excellent as a salad. Pkt. 10 cts.; oz. 40 cts.; $1 / 4 \mathrm{Ib}$. $\$ 1.25$.

For Witloof Chicory, see description on page 108.

\section{Collards}

One ounce will sow 200 feet of row

Georgia. Cultivation same as Cabbage, of which it is really a tall loose-leaved form. Grows 3 feet high forming a cluster of undulated leaves at the top of its long stem. Pkt. $10 \mathrm{cts}$.; oz. 20 cts.; $1 / 4$ Ib. 50 cts.

\section{Sweet Corn}

\section{One pound will plant about 200 hills}

Average garden soil is very satisfactory. Sow after the ground becomes warm; first planting may generally be made about May 15. Continue successive plantings every two to three weeks until the end of July. Plant 1 inch deep in hills, 3 feet part each way, dropping six kernels to each hill. Thin to three plants per hill. With large varieties, make hills 4 feet apart each way. Sweet Corn may also be sown in rows 3 feet apart and thinned so that the plants will stand 10 inches apart in the row. Hoe frequently, keeping free from weeds, and draw soil up to stem; break off side shoots.

Black Mexican. An interesting variety and one of the best second-early sorts where tenderness and sweetness are desired. The stalks grow about $61 / 2$ feet high, producing ears usually 8 inches long and 8-rowed. The dry grain is dark bluish black and the ripe Corn is of the same color, but when "green" is white. Pkt. 10 cts.; 1/2Ih. 25 cts.; lb. 40 cts.; 2 Ibs. 75 cts.; 5 lbs. $\$ 1.75$.

Country Gentleman. This extremely popular variety has a small white cob densely packed with irregular rows of very long, slender, white "shoe-peg" grains of excellent quality. The ears are 7 to 8 inches long, produced on $61 / 2$ to 7 -foot stalks. Some stalks yield three ears each. It matures rather late but is an excellent variety. Pkt. 10 cts.; 1/2 lb. 25 cts.; Ib. 40 cts.; 2 lbs. 75 cts.; 5 lbs. $\$ 1.75$. 


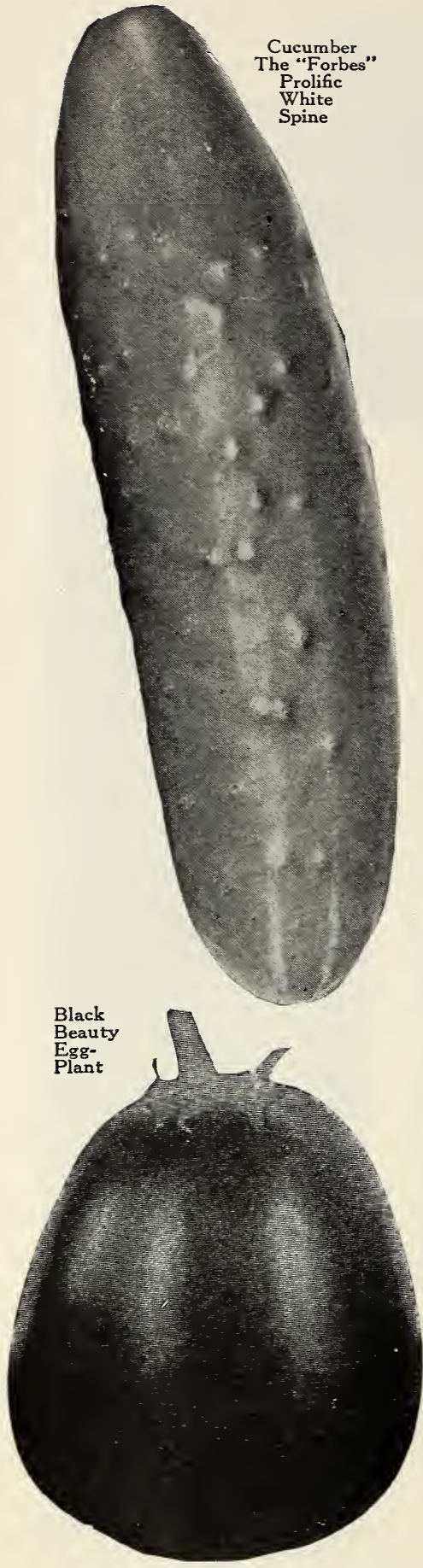

\section{Cucumbers}

One ounce will plant 50 hills

A warm, sandy loam, enriched with well-rotted manure, is best. Sow May 15, in hills about 4 feet apart each way, dropping ten seeds in each hill, and covering firmly with less than an inch of finely pulverized soil. It is well, beforehand, to mix one shovelful of well-rotted manure with the soil of each hill. For a succession, sow every ten days. After all danger from insect attack is past, thin to three or four plants to the hill. If wanted for early use, start in pots in hotbed about April 1 and transplant outdoors when weather is safe. For pickling varieties, sow from June 15 to JuIy 10 . We advise that all fullsized Cucumbers should be picked, whether required or not.

The "Forbes" Prolific White Spine. For vigor, earliness, uniform size of fruit, and heavy cropping from the start, it has no equal. The fruits are dark green from blossom to stem end, 8 to 9 inches long, and nicely tapered. This strain is earlier than other White Spine varieties, and will stand the hot sun better. Pkt. 10 cts.; oz. 25 cts.; 1/4 Ib. 65 cts.

Forbes Straight Pack. A wonderfully choice variety, which, though developed for greenhouse culture, has proved remarkably successful outdoors. Under good culture and favorable conditions this variety will compare favorably with the best indoor Cucumber as to size, color, and finish. It will average 12 inches in length, is a beautiful dark green, and almost spineless. Pkt. 15 cts.; oz. 50 cts.; 1/4 Ib. $\$ 1.50$.

Jersey Pickling. Of slender, cylindrical form, 8 inches Iong. Pkt. 10 cts.; oz. 25 cts.; $1 / 4$ Ib. 65 cts.

Long Green Improved. The vigorous vines bear slender, dark green fruits, 12 to 15 inches Iong. The bulk of the crop matures late. Pkt. 10 cts.; oz. 25 cts.; 1/4 Ib. 65 cts.

\section{Forcing Cucumbers}

Improved Telegraph. A fine greenhouse variety of quick growth, handsome and prolific. Pkt. (10 seeds) 35 cts.

Milwaukee Forcing. Long, smooth, dark green fruits of quality, excellent for exhibition. Pkt. (10 seeds) $35 \mathrm{cts}$.

\section{Dandelion}

\section{One ounce will sow 100 feet of row}

Use a clean, warm, rich soil. Sow in early spring in rows $11 / 2$ feet apart, covering firmly with $1 / 2$ inch of fine soil. When plants are well developed, thin or transplant to 10 inches apart. Leaves will be fit to cut the following spring. Blanching the leaves removes to some extent, the bitter taste without impairing the qualities which make them valuable greens. Blanching may be done by covering with leaves or loose litter, or by boarding them over. The leaves are used as salad or as boiled greens, and the roots as a substitute for coffee.

Improved Thick-leaved. Unsurpassed in thickness of leaf and deep green color. It grows compactly, forming a regular, up right tuft. Pkt. 15 cts.; $1 / 2$ oz. 60 cts.; oz. $\$ 1 ; 1 / 4 \mathrm{Ib}$. $\$ 3.50$.

\section{Eggplant}

\section{One ounce will produce about 1,000 plants}

Any good garden soil will serve, but fertilizing will repay. Start the seed in warm greenhouse or hotbed in March or April. As the seed is slow to germinate, press soil firmly when covering. Be careful not to check growth by exposure. When plants are 2 inches high transplant to 3 -inch pots. Set out in open ground about June 1 , allowing $21 / 2$ feet between plants each way. Hoe frequently, keeping the soil loose and fine. Black Beauty. This is the earliest and best of all the largefruited Eggplants. The bushes are well-rounded, sturdy, branching freely near the ground. Fruits are large, thick, heavy at the base, and reducing toward the stem, of a dark purplish black color. Pkt. 15 cts.; oz. 85 cts.; $1 / 4$ Ib. $\$ 2.50$. 


\section{Endive}

One ounce will sow 150 feet of row

Any garden soil will do. For an early supply, sow about April 15. As it is used mainly in fall months, the main sowings are made in June and July, in rows about $11 / 2$ feet apart, covering seed firmly with about $1 / 2$ inch of soil. When plants are of sufficient size, thin to 8 to 12 inches apart in the row. Keep clear of weeds. When nearly full grown, gather the outer leaves together in conical form and tie the tips together in order to blanch the heart of the plant. Three to six weeks are required for blanching. Fine for fall and winter salads; also for greens and flavoring soups and stews.

Broad-Leaved Batavian (Endivia Scariola). Rosette is often 16 inches in diameter, with broad, twisted or waved green leaves, and thick white midribs. Makes a fine "head," and blanches easily. Pkt. 10 cts.; oz. 30 cts.; 1/4 Ib. 75 cts.

Mammoth Bordeaux Curled. This fine variety attains Iarge size, growing 20 inches in diameter. The center is very full and close. One of the hardiest; suitable for summer and autumn. Pkt. 10 cts.; oz. 30 cts.; 1/4Ib. 75 cts.

\section{Garden Herbs}

Herbs delight in a rich, mellow soil. Sow seeds early in spring, in shallow drills, 1 foot apart. When plants are 3 to 4 inches high, thin out or transplant. Before they come into full bloom, cut the plants on a dry day, tie in bunches, and hang up to dry quickly. The powdered leaves are used for flavoring or medicinal purposes.

Anise.-Used for garnishing, seasoning and for cordials. Pkt. 10 cts.; oz. 35 cts.

Basil, Sweet. Leaves are used for flavoring soups, stews, and other dishes. Pkt. 15 cts.; oz. 40 cts.; 1/4 Ib. $\$ 1.50$.

Borage. Flowers are excellent for bees and the leaves are used in salads. Pkt. 15 cts.; oz. 40 cts.; $1 / 4 \mathrm{Ib}$. $\$ 1.50$.

Dill. The leaves are used in pickles and for flavoring soups and sauces. Pkt. 10 cts.; oz. 20 cts.; $1 / 4 \mathrm{Ib} .65$ cts.

Fennel, Florence (Finocchio). A delicious vegetable when boiled and served with a cream dressing. Has an agreeable, aromatic flavor, sweet taste, and delicate odor. When the enlarged base of the leaf-stalk is 2 inches across, half cover with earth. After ten days, cuttings can be made and continued as the plants grow. Responds to liberal watering. Pkt. 10 cts.; oz. 30 cts.; 1/4lib. 85 cts.

Fennel, Sweet. The boiled leaves are used in fish sauces and in garnishing, the seeds for flavoring. Pkt. 10 cts.; oz. 30 cts.; $1 / 4$ Ib. 85 cts.

Lavender. Leaves are used for seasoning and the flowers for perfumes. Pkt. 15 cts.; oz. 75 cts.; $1 / 4 \mathrm{Ib}$. $\$ 2.75$.

Marjoram, Sweet. The leaves and shoot ends are used for flavoring when green in summer or when dried in winter. Pkt. 15 cts.; oz. 50 cts.; $1 / 4$ Ib. $\$ 1.75$.

Rosemary. Yields an aromatic oil. Leaves used for seasoning. Pkt. 15 cts.; oz. 50 cts.; 1/4Ib. \$1.75.

Sage. Plants grow to 3 feet in diameter and are hardy. The leaves and tops are used for seasoning. Pkt. 15 cts.; oz. 50 cts.; $1 / 4$ Ib. $\$ 1.75$.

Savory, Summer. The leaves and young shoots are used for flavoring. Pkt. 15 cts.; oz. 40 cts.; 1/4lb. $\$ 1.50$.

Thyme, Broad-leaved English. Used for seasoning and for a tea for nervous headache. Also used for bee-food. Pkt. 15 cts.; oz. 75 cts.; $1 / 4$ Ib. $\$ 2.75$.

Wormwood. Has medicinal qualities beneficial to poultry. Also used for flavoring. Pkt. 15 cts.; oz. 40 cts.; 1/4Ib. $\$ 1.50$.

\section{Horse-Radish Roots}

Mark off the rows $21 / 2$ feet apart, and set the roots $11 / 2$ feet apart in the rows, the small ends down and the tops 1 to 3 inches below the surface.

Maliner Kren. A variety producing very large, pure white roots. Strong sets, 30 cts. for $10, \$ 1.75$ per $100, \$ 15$ per 1,000 .
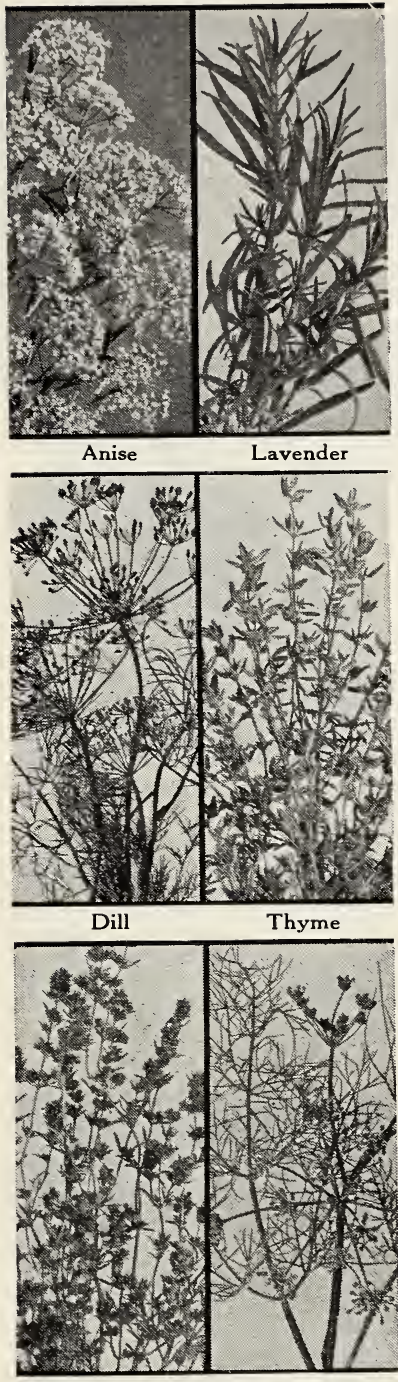

Sweet Marjoram Sweet Fennel

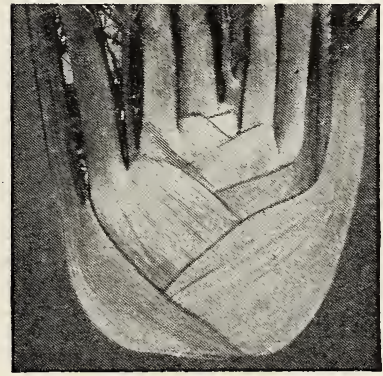

Florence Fennel 


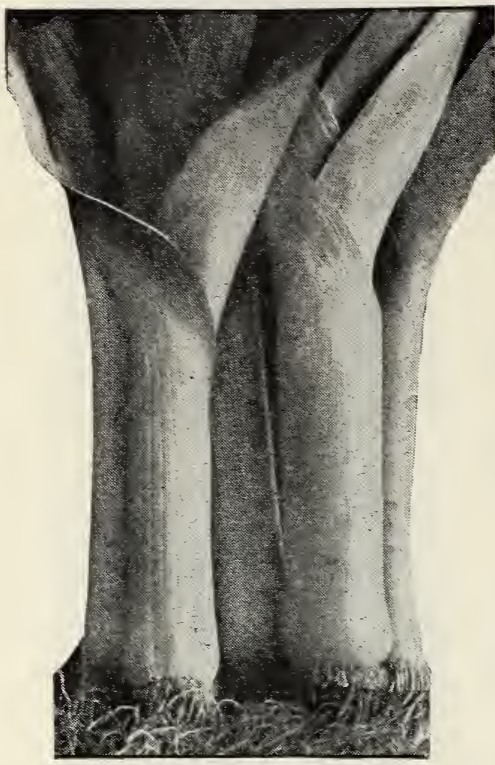

American Flag Leeks

Not nearly as many gardeners grow Kohlrabi in their home-gardens as should. It is almost unknown in many country districts, which is unfortunate because it is easy to grow, well-flavored, and is very nutritious.

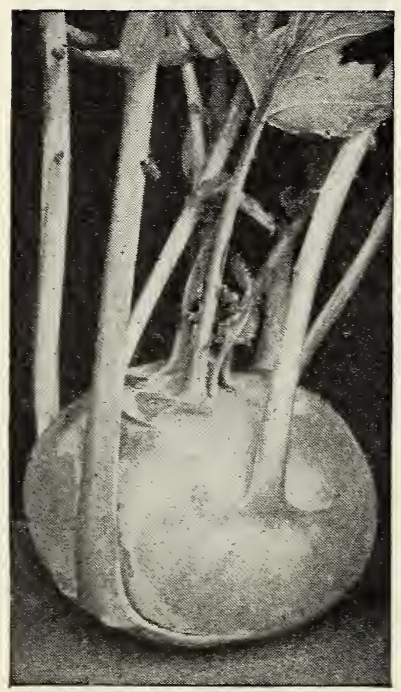

Smooth White Vienna Kohlrabi

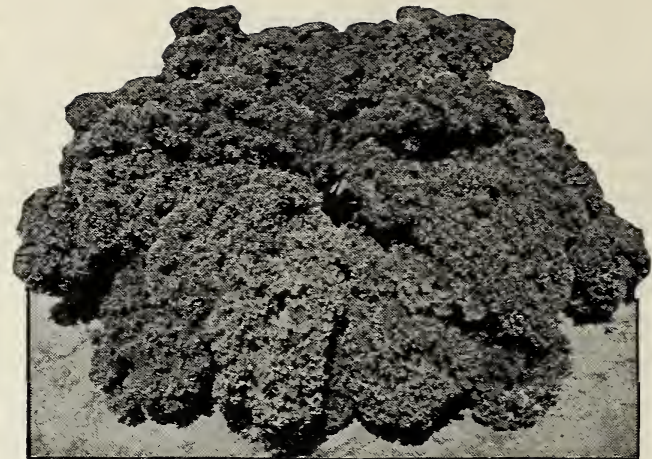

Dwarf Green Curled Scotch Kale

\section{Kale}

One ounce will sow 200 feet of row

For a late fall or early winter crop, sow early in June; for spring crop sow in September and cover with straw for winter. Sow in rows $1 \frac{1}{2}$ to 2 feet apart, so that plants may be cultivated when small. Cover seed firmly with $1 / 2$ inch of soil. Thin or transplant plants to $11 / 2$ or 2 feet apart in the row. A frost greatly improves the quality.

Blue Curled Dwarf Siberian. Very vigorous, hardy variety of dwarf, spreading habit, with bluish green foliage, beautifully curled and crumpled at the edges. Will stand longer than any other sort before seeding. Pkt. 10 cts.; oz. 30 cts.; $1 / 4$ lb. 75 cts.; Ib. $\$ 2$.

Dwarf Green Curled Scotch. This is Iow-growing, rarely exceeding $11 / 2$ feet in height, with finely curled, spreading, bright green, long leaves, produced in great abundance. Pkt. 10 cts.; oz. 30 cts.; 1/4lb. 75 cts.; Ib. \$2.

\section{Kohlrabi}

\section{One ounce sows 200 feet of row}

Sow at intervals from April 15 to June, in drills $11 / 2$ feet apart, covering firmly with $1 / 2$ inch of soil. Transplant or thin out as needed. May be sown in hotbeds February 15 and planted out after frost. Sowings may be made the latter part of July for fall use. Use the roots when 2 inches in diameter.

Early Purple. Very early, with small top, leaf-stems tinged with purple. Bulbs medium size, purple; flesh white and delicate. For forcing and early outdoor planting. Pkt. 10 cts.; oz. 35 cts.; 1/4lb. \$1.

Smooth White Vienna, Short-Ieaved. A very early variety having only a few leaves, these being less than 8 inches long. Smooth white bulbs of medium size and fine quality, ready for use two and a half months after sowing. This is well adapted for sowing in hotbeds about February 15 and transplanting, when about 3 inches high, to permanent ground. Pkt. 10 cts.; oz. 35 cts.; $1 / 4 \mathrm{Ib} . \$ 1$.

\section{Leek}

One ounce will sow 100 feet of row

A deep, rich light soil is best. Sow in early spring, in rows 12 inches apart and $1 / 2$ inch deep, and cover firmly. Thin plants to 6 inches apart in the row and draw the soil about them when cultivating. If long, white, tender Leeks are desired, transplant when 6 inches high, setting 4 inches apart in trenches about 2 feet apart, gradually earthing up to top of neck.

American Flag: A very fine, early, productive variety, being a strong, quick grower, and of mild flavor. The stems are 2 inches in diameter and blanch 10 inches from the root. An excellent sort for fall and early winter sowing. Pkt. 10 cts.; oz. 35 cts.; $1 / 4$ Ib. $\$ 1$. 


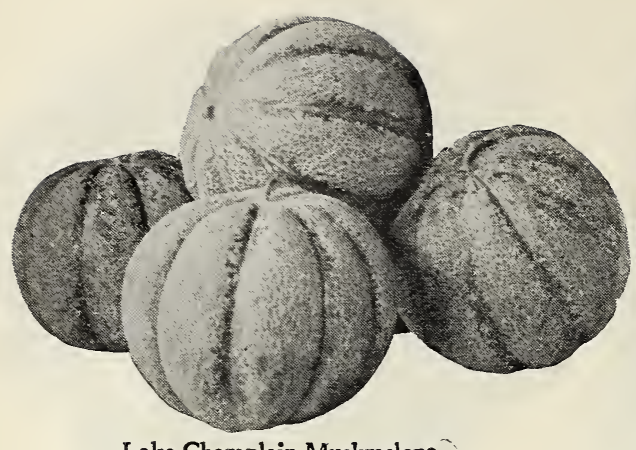

Lake Champlain Muskmelons

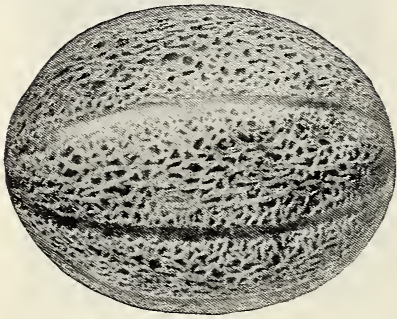

Maryland Muskmelon

Melons may be started earlier on pieces of sod upside down in a hotbed or in peatpots, setting them outdoors when the ground is warm. This will give you ripe fruit much earlier.

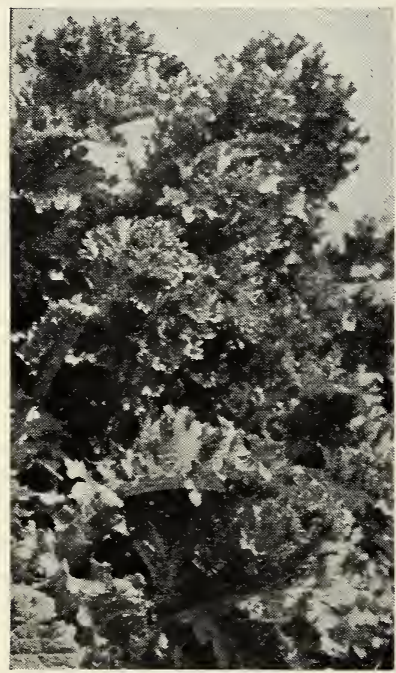

Fordhook Fancy Mustard

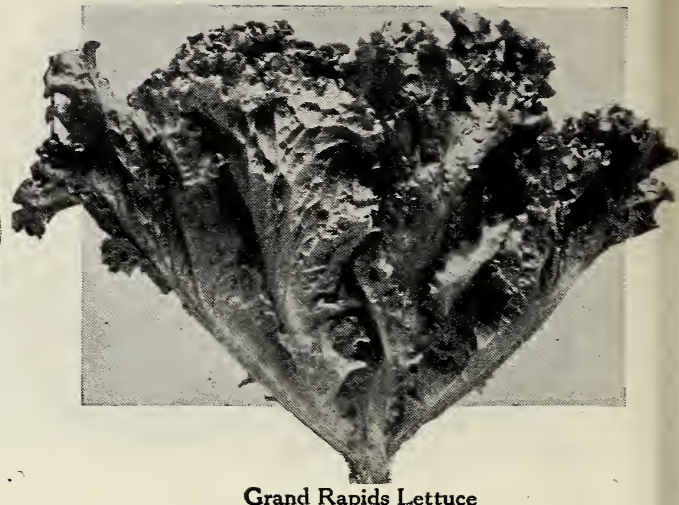

Loose-leaved Lettuce

Early Curled Simpson. Yellowish green, curly leaves; very early. Pkt. 10 cts.; oz. 30 cts.; 1/4lb. 75 cts.; Ib. $\$ 2$.

Grand Rapids. This is fine for greenhouse forcing. The hardy plant, upright and carried weIl above the soil, forms loose clusters of large, thin, bright green leaves, with crimped edges. Pkt. 10 cts.; oz. 30 cts.; $1 / 4$ Ib. 75 cts.; Ib. $\$ 2$.

\section{Muskmelon or Cantaloupe}

One ounce will plant 50 hills

Early in May plant in hills 4 feet apart, dropping six to eight seeds to the hill. When large enough, thin out to four strong plants. Spray with Bordeaux to prevent blight and cultivate freely till the vines cover the ground.

Bender's Surprise. A high-class melon of delicious flavor and sweetness, with very thick, deep orange flesh. The large, oval, coarsely netted melons often weigh from 10 to 15 pounds each. The flesh is so thick and the rind so firm that Bender's Surprise will keep perfectly for a week after picking. Pkt. 15 cts.; oz. 35 cts.; 1/4 Ib. \$1; Ib. \$3.

Lake Champlain. The earliest Muskmelon we know. The plant is very productive, very vigorous and healthy, setting and ripening melons rapidly even under adverse conditions. The melons are medium-sized, flattened round, deeply creased, and nicely netted. The golden yellow flesh is deep and very sweet. Pkt. 15 cts.; oz. 50 cts.; $1 / 4$ Ib. $\$ 1.50$; Ib. $\$ 5$.

Maryland. Of the Rocky Ford type, but far more productive, larger and easily ten days earlier. Vines are strong and vigorous, producing slightly oval, closely netted melons. Skin is light golden; flesh bright green and luscious, Pkt. 15 cts.; oz. 35 cts.; $1 / 4$ Ib. $\$ 1$; Ib. $\$ 3$.

Rocky Ford or Netted Gem. This is a vigorous, medium-early variety. Fruits are oval, slightly ribbed, and covered with fine netting. The flesh is thick, green, and highly flavored. Pkt. 15 cts.; oz. 35 cts.; 1/4Ib. \$1; Ib. \$3.

\section{English Forcing Melons}

Sutton's Blenheim Orange. Handsome scarlet-fleshed variety which is beautifully netted and sets well. Pkt. 50 cts.

Sutton's Emerald Gem. Unusually thick, rich, green flesh of superb flavor. Melons are large and finely netted. Pkt. 50 cts.

\section{Mustard}

\section{One ounce will sow 100 feet of row}

Fordhook Fancy. The long, slender, plume-like, finely curled leaves are a deep green color, with edges deeply cut. Stands a long time before running to seed. Pkt. 10 cts.; oz. 25 cts.; $1 / 4$ Ib. 75 cts.; Ib. $\$ 2$. 


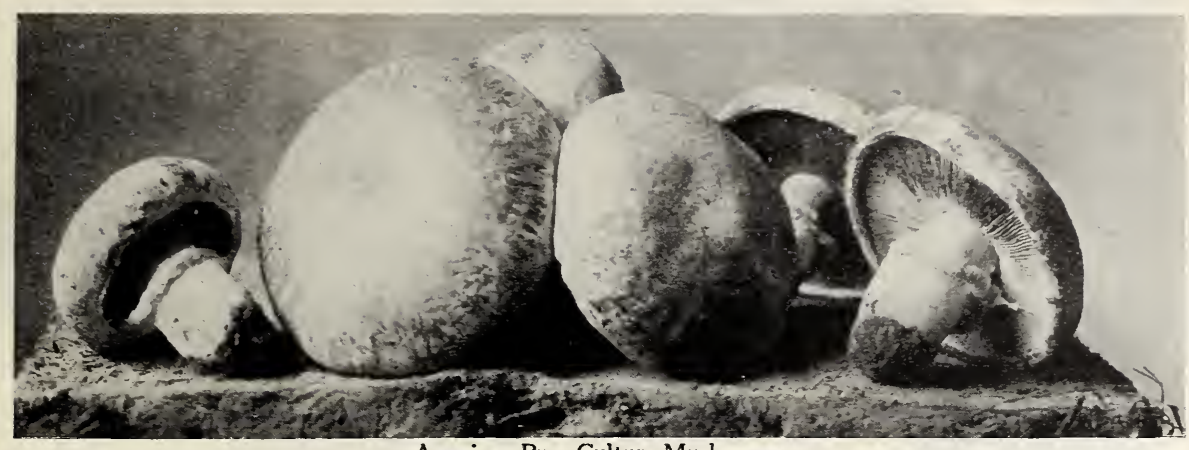

American Pure Culture Mushrooms

\section{Mushrooms}

For the culture of Mushrooms you need (1) a shed or cellar which can be kept damp and at a temperature around 60 degrees; (2) fresh horse manure from healthy animals, free of shavings, and with little straw; (3) some good garden soil; (4) some hay or straw; (5) high-grade Pure Culture Spawn; (6) a hotbed thermometer. Turn the manure for several days, keeping it slightly moist; make firm beds with it 1 foot thick, and let it steam. Try the temperature of the manure: it will go over $100^{\circ}$ and then faII; at $85^{\circ}$ plant spawn just under the surface and then cover the beds with hay. A mould will be noticed on the manure after a week; remove the hay and spread 1 inch of soil in its place. Keep the bed slightly moist, using warm water, and occasionally sprinkle the floors.

\section{Brick Spawn, American Pure Culture \\ Ten pounds will spawn 10 square feet}

Spores have been selected from specimens and transferred to bricks of compressed manure and loam. Break the brick into inch pieces and plant 1 foot apart. Brick (about 11/2 lbs.) 35 cts.; 10 bricks $\$ 3.25 ; 25$ bricks $\$ 7 ; 100$ bricks $\$ 25$.

\section{Onion}

\section{One ounce will sow 100 feet of row}

Soil should be well fertilized. For early crop sow seed in coldframes in February, transplanting when large enough to handle. Open-ground sowing should be made right after frost has gone. Sow $1 / 2$ inch deep in rows 12 inches apart. If thinning is needed, the young plants may be used for salad.

Ailsa Craig. (Selected.) A very large, oval variety with pale straw-colored skin. It keeps well and has a mild flavor. Pkt. 15 cts.; oz. 65 cts.; $1 / 4$ Ib. $\$ 1.75$; Ib. $\$ 5$.

Prizetaker. A main-crop Onion of the largest size and nearly globular form sloping slightly at the shoulder. Skin is yellowish brown. Flesh is creamy white, very mild, and of fine flavor. Pkt. 15 cts.; oz. 55 cts.; 1/4lb. \$1.50; Ib. $\$ 4$.

Selected Yellow Globe Danvers. The bulbs are medium to large, globe-shaped, with small neck and ripen evenly to a rich, coppery yellow color. Flesh creamy white, crisp, solid and of mild and excellent flavor. A fine keeping variety. Pkt. 15 cts.; oz. 55 cts.; 1/4lb. \$1.50; Ib. \$4.

Southport Red Globe. Large, globe-shaped bulbs with smaII neck, smooth and glossy, and of deep, purplish red color. Flesh is white, tinged with light purple, fine-grained and tender, but rather strongly flavored. One of the best keepers. Pkt. 15 cts.; oz. 55 cts.; 1/4 Ib. \$1.50; Ib. \$4.

Southport White Globe. The finest of all white Onions and a good keeper. Has the true globe shape; full at the base and shoulder. Pkt. 15 cts.; oz. 55 cts.; 1/4 Ib. \$1.50; Ib. \$4.

White Portugal or Silverskin. A frne white sort for sets, or using young. Mature bulbs are of medium size, flattened globe shape. Pkt. 15 cts.; oz. 55 cts.; 1/4Ib. \$1.50; Ib. \$4.

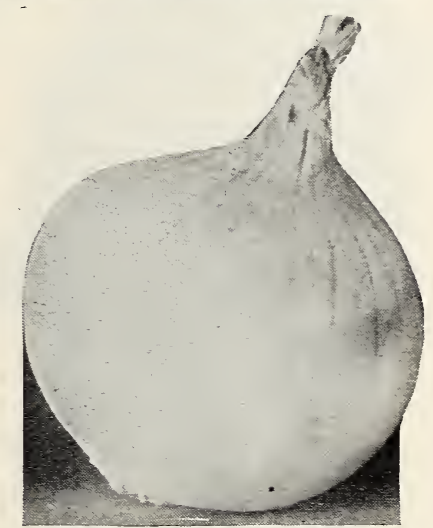

Southport White Globe Onion

Weeding Onions is a classical garden job, and no boy ought to grow up without the benefit of its fine back exercise. It is frne training for school athletics.

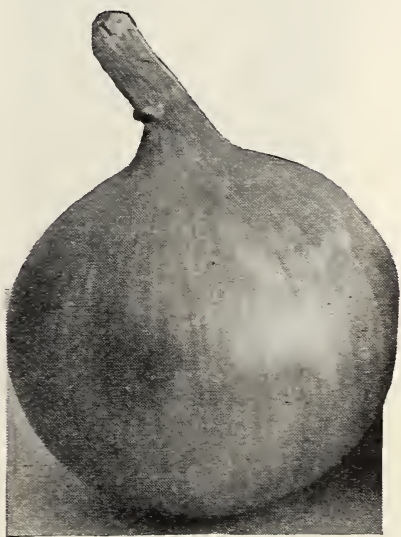

Selected Yellow Globe Danvers 


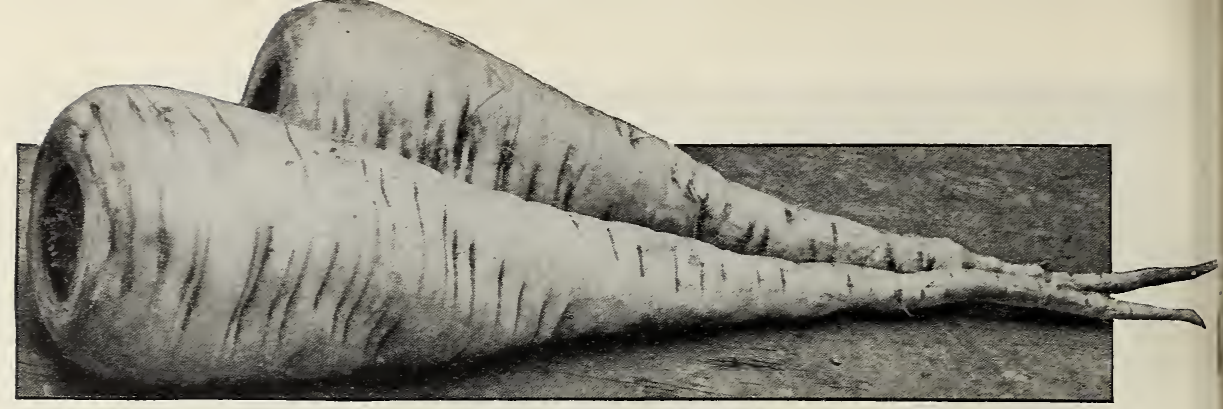

Ideal Hollow Crown Parsnips
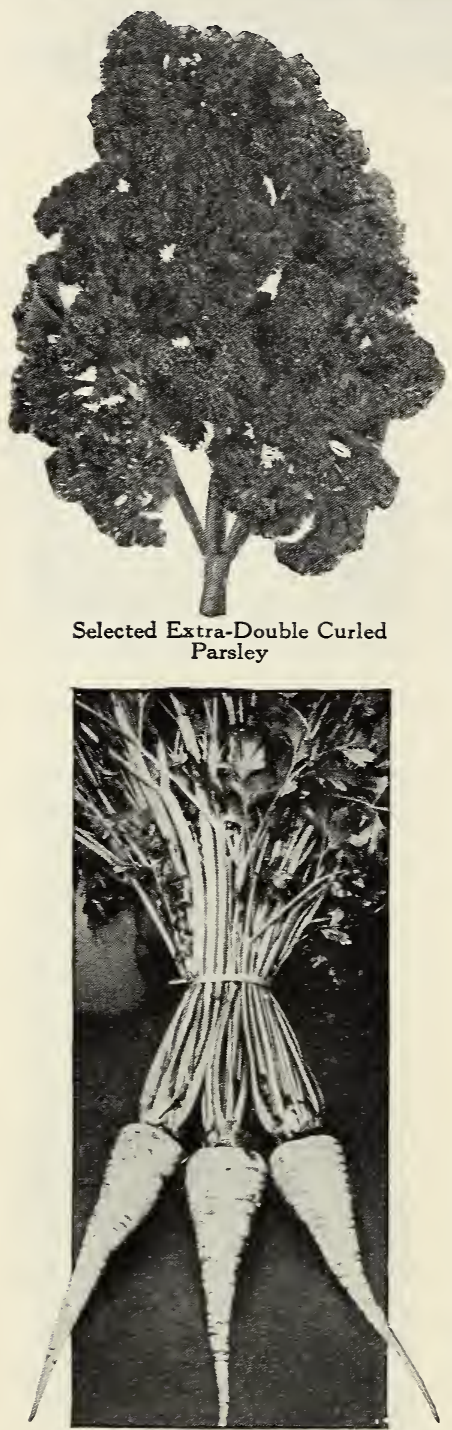

Hamburg or Parsnip-rooted Parsley

\section{Okra or Gumbo}

One ounce will sow 100 feet of row

Sow after soil is warm, in rows 3 feet apart, $1 \frac{1}{2}$ feet apart in the row. The pods are used for soups and stews and should be gathered while still young and tender.

Perkins' Mammoth. This variety is about 3 feet high, very early and productive. Pods are deep green, very long, slender, slightly corrugated, very tender and of good quality. Pkt. 10 cts.; oz. 20 cts.; 1/4lb. 45 cts.; Ib. $\$ 1.50$.

\section{Parsley}

\section{One ounce will sow 150 feet of row}

Parsley thrives in a deep, rich, mellow soil, very finely pulverized. As the seed germinates very slowly, sow as early as possible in the spring, in rows 12 inches apart. Cover with $1 / 2$ inch of fine soil, pressing it down firmly. When the plants are well up, thin to 2 inches apart in the row. Seed will germinate more rapidly if soaked over night in slightly warm water. During the hot summer, Parsley may turn brownish-red. To prevent this, plant a taller growing crop next to it, so that it has partial shade. Just before frost, pick as much as is needed. Dry, powder, and store in glass jars for winter use.

Hamburg or Parsnip-rooted. This variety is grown for the roots, which mature early, are short, thick, and in appearance like a parsnip, although smaller. Flesh is white, a little dry and flavored somewhat like parsnips. Pkt. 10 cts.; oz. 20 cts.; $1 / 4$ Ib. 50 cts.; Ib. $\$ 1.50$.

Italian or Plain-leaved. The very dark green leaves are flat, deeply cut but not curled. Pkt. 10 cts.; oz. 20 cts.; 1/4/L. 50 cts.; Ib. $\$ 1.50$.

Selected Extra-Double Curled. This excellent strain is very vigorous, growing short stiff stems, with compact, frnely cut, very densely curled leaves of an extremely dark green color. Pkt. 10 cts.; oz. 20 cts.; 1/4Ib. 50 cts.; lb. \$1.50.

\section{Parsnip}

\section{One ounce will sow 150 feet of row}

Use a deep rich, sandy soil, although any deep, mellow, moderately rich soil will produce good roots. Sow as early in spring as possible, in rows 1 foot apart, covering firmly with about $1 / 2$ inch of fine soil. When plants are well up, thin to 2 to 3 inches apart in the row. Parsnip seed is very slow to germinate. Soil should be pressed down firmly over seeds. Cultivate frequently. Although Parsnips require a long season (about 100 to 120 days) to grow fine large roots, very good small roots may be grown by sowing later. When heavy frosts set in, dig roots, store in cool cellar, and cover with soil.

Ideal Hollow Crown. The roots are about 12 inches Iong, with smooth white skin, uniform in shape, tapering evenly from a heavy shoulder down to a smaII root. The flesh is tender, of best quality. Pkt. 10 cts.; oz. 20 cts.; $1 / 4 \mathrm{Ib}$. 60 cts.; Ib. \$1.65. 


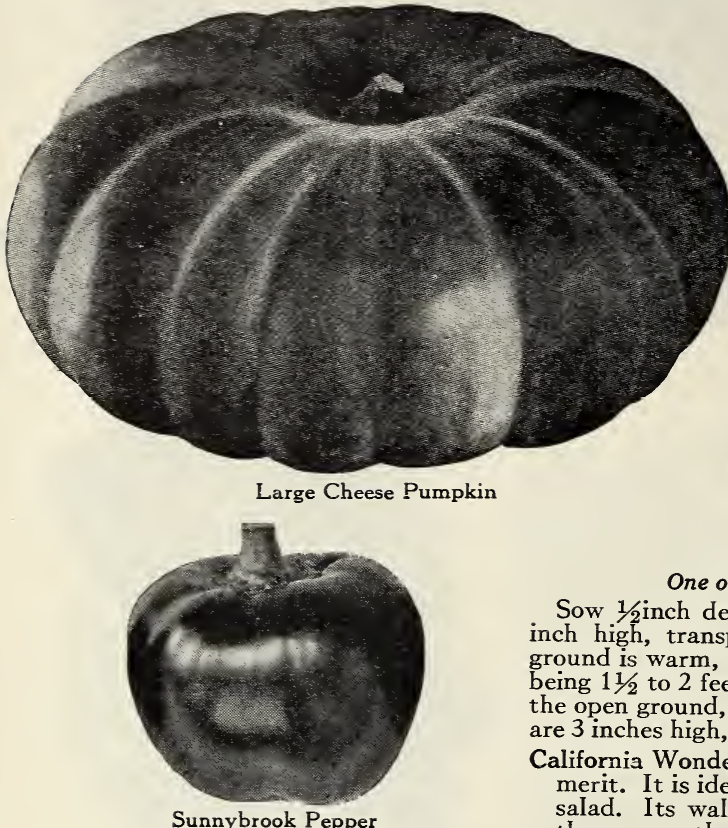

When you pick the fruits of California Wonder Pepper you will be surprised at their unusually heavy weight. One fruit, exactly like many others on one plant, measured $4 \frac{1}{2}$ inches across and weighed just over $101 / 2$ ounces. This unusual weight for a Pepper is due to the comparatively small seed cavity and very thick meaty walls of this new variety.

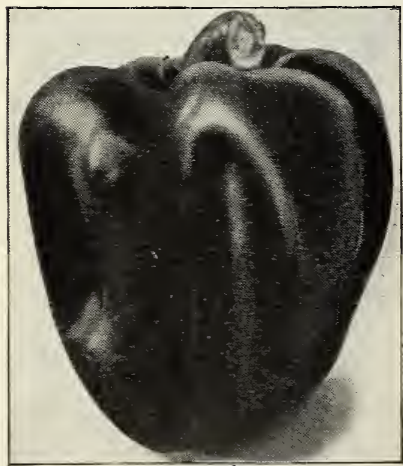

Ruby King Pepper

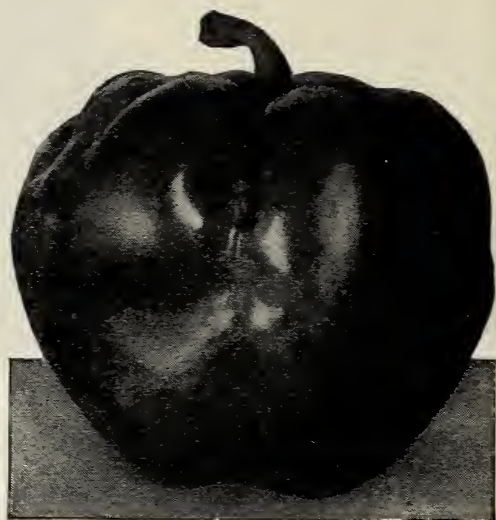

Chinese Giant Pepper

Pepper

One ounce will produce 1,000 to 1,200 plants

Sow $1 / 2$ inch deep in hotbed in March. When plants are 1 inch high, transplant into 2 -inch pots and, after the open ground is warm, transplant to rows $21 / 2$ to 3 feet apart, plants being $11 / 2$ to 2 feet apart in the row. Seed may also be sown in the open ground, after danger of frost is past, and when plants are 3 inches high, transplanted as above. Cultivate frequently. California Wonder Pepper. Here's a new, Iarge Pepper of real merit. It is ideal to stuff and bake, or to serve whole with salad. Its walls are exceptionally thick, heavier and firmer than any other sort, and the flesh is deliciously sweet and spicy, with no bite to it. The bright, attractive green changes to a brilliant light crimson. Pkt. 25 cts.; 5 pkts. $\$ 1$.

Chinese Giant. An exceedingly large red Pepper. The plants are vigorous but stocky, about 2 feet high, weIl branched and thickly set with fruits. The monstrous mild fruits mature Iater than Ruby King, are blocky in form, 4 to 5 inches broad at the top and of equal length, divided into four or more large ridges, and of a most brilliant glossy scarlet color. Pkt. 15 cts.; $1 / 2$ oz. 60 cts.; oz. $\$ 1 ; 1 / 4 \mathrm{Ib}$. \$3.

Long Red Cayenne. A red-hot variety. The slender, pointed, 3 -inch pods taper from $1 / 2$ inch to the point. Pkt. 15 cts.; $1 / 2$ oz. 50 cts.; oz. 85 cts.; $1 / 4$ Ib. $\$ 2.75$.

Ruby King. The plants are $21 / 2$ feet high and very productive. Fruits are 4 to 5 inches Iong, of a deep green color when young and bright red when ripe. The flesh is thick and mild. Pkt. 10 cts.; $1 / 2$ oz. 40 cts.; oz. 75 cts.; $1 / 4$ Ib. $\$ 2.50$.

Sunnybrook. Of the Pimiento type, averaging. 3 inches in diameter and 2 inches deep, rich, deep scarlet in color, produced in clusters of four or five. Pkt. 15 cts.; $1 / 2$ oz. 50 cts.; oz. 85 cts.; $1 / 4$ Ib. $\$ 2.75$.

\section{Pumpkin}

One ounce will plant about 25 hills

Plant after the ground has become thoroughly warm, in hills 8 feet apart each way, dropping eight seeds to a hill. Cover frrmly with 1 inch of soil. After plants are weIl started, thin to 4 to each hill. Pumpkins may also be planted in the corn-field, dropping three seeds in every fourth hill of corn.

King of the Mammoths, or Jumbo. Largest of all Pumpkins, often weighing 200 pounds. Shape flattened-round; skin light orange-colored, slightly rough; flesh bright yellow, of good quality. Pkt. 10 cts.; oz. 25 cts.; $1 / 4$ Ib. 75 cts.; Ib. $\$ 2$.

Large Cheese or Kentucky Field. The fruits are Iarge, flattened-round; skin mottled light green and yellow, changing to creamy yellow when mature; flesh yellow, tender, and excellent. Pkt. 10 cts.; oz. 20 cts.; 1/4Ib. 60 cts.; Ib. $\$ 1.50$.

Pie or Winter Luxury. Medium size, nearly round; light yellow, smooth skin, with russet netting; flesh yellow, and sweet. Pkt. 10 cts.; oz. 25 cts.; 1/4Ib. 75 cts.; Ib. $\$ 2$. 


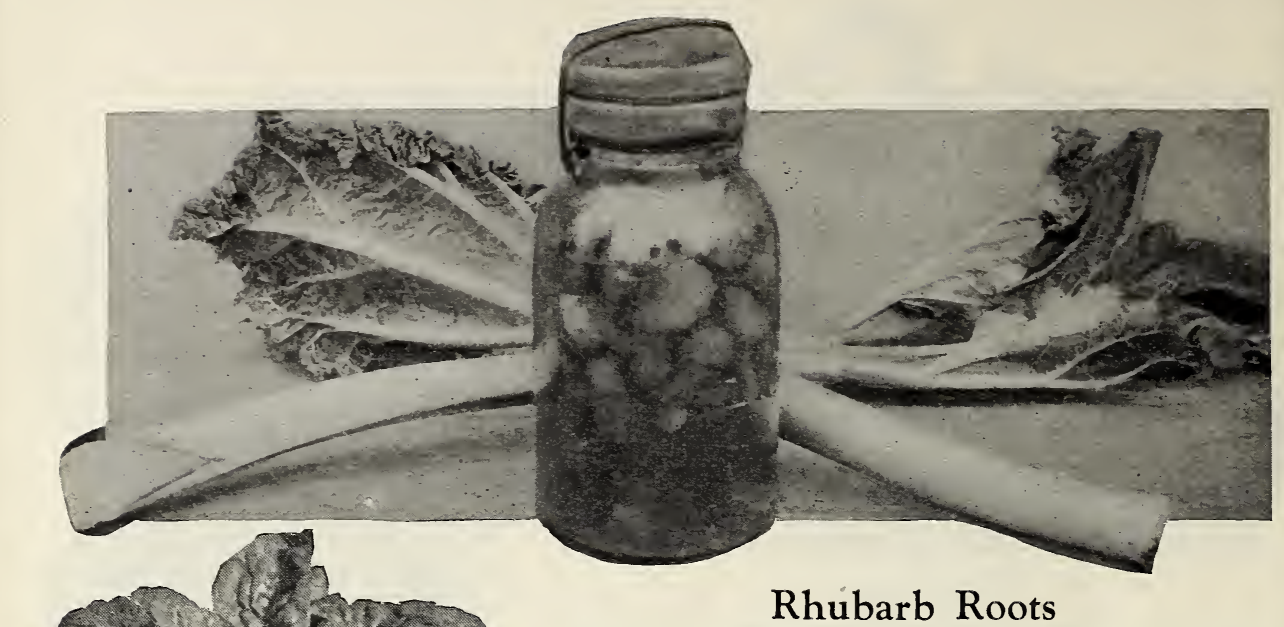

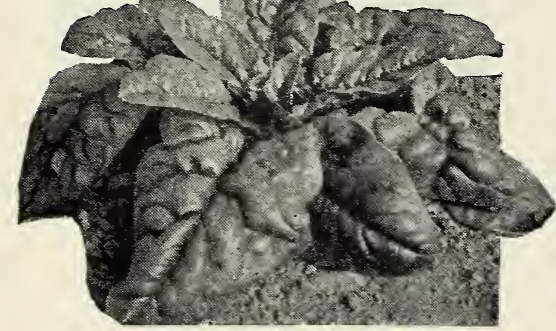

New Summer Spinach

Salsify, when cooked, is a really delicious vegetable. Boil it like carrots or after half boiling, grate it and make into flattened balls and fry like oysters.

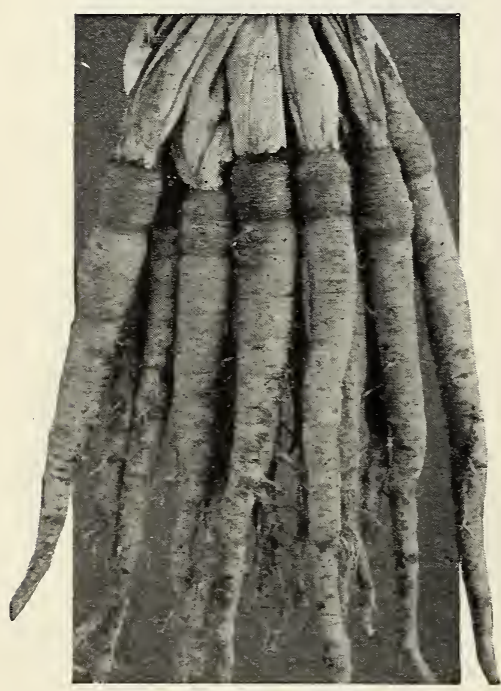

Sandwich Island Salsify
Rhubarb succeeds best in a very rich, deep soil. If propagated by dividing the roots, it may be done in faII or spring, setting divisions out 3 feet apart. Use plenty of manure.

Extra-Select Clumps. 25 cts. each; $\$ 2.50$ per doz.; $\$ 20$ per 100 .

\section{Salsify . Oyster Plant \\ One ounce will sow 50 feet of row}

Sow early in spring, in rows 12 inches apart. Cover the seed firmly with $1 / 2$ inch of fine soil; thin to 1 inch apart in the row. This is one of the most desirable winter vegetables; the roots when cooked are very palatable and nutritious.

Mammoth Sandwich Island. Large, thick, smooth, white roots. Pkt. 10 cts.; oz. 35 cts.; $1 / 4$ Ib. $\$ 1$; Ib. $\$ 3$.

\section{Sorrel}

One ounce will sow 100 feet of row

Sow early in spring, thinly in rows 12 to 18 inches apart. Thin to 6 to 8 inches apart. Commence cutting two months after planting. The plants continue to bear for three years.

Large French Broad-leaved. Large, pale green leaves of mild, acid flavor; esteemed as a salad, also cooked as greens. Pkt. 10 cts.; oz. 30 cts.; 1/4Ib. 85 cts.; Ib. \$2.50.

\section{Spinach}

\section{One ounce will sow 100 feet of row}

Spinach grows easily in spring and fall, but not so weIl in summer. Make first sowing as early as possible and repeat at intervals until June 1 . Sowings for faII use may be made from August 1 to September 10 . To winter over for spring use, sow from September 10 to October 5, according to season. Rows should be 1 foot apart and plants about 6 inches apart in the row. For summer use we recommend New Zealand.

New Long-Standing Savoy-leaved. A fine strain of outstanding merit. It will stand in condition ten to fourteen days longer before bolting than regular Savoy and is darker green. It is intensely crumpled and blistered and very uniform. Oz. 15 cts.; 1/4l/b. 30 cts.; Ib. 75 cts.; 5 lbs. \$3.

New Summer. We recommend this especially for spring planting, during April and May. It forms a stocky plant with dark green blistered leaves of good substance, and wiII not bolt to seed or lose color for nearly two weeks. Oz. 15 cts.; $1 / 4$ Ib. 30 cts.; Ib. 75 cts.; 5 Ibs. $\$ 3$.

New Zealand. A distinct Spinach differing from any true Spinach. Thrives in hot weather on any soil. The plant, of spreading habit, is very Iarge, with comparatively smaII, broad, pointed leaves. The tender shoots can be cut throughout the summer. Oz. 15 cts.; $1 / 4 \mathrm{Ib} .50 \mathrm{cts}$.; Ib. $\$ 1.50$. 


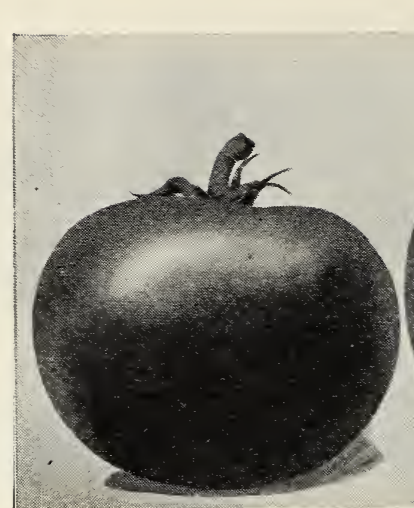

Selected Earliana

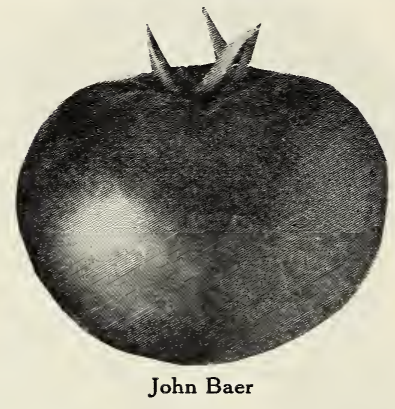

Tomatoes are ideal for a home garden crop and yield heavily in a small space. Hot sun is needed to ripen them and plenty of water to keep them growing.

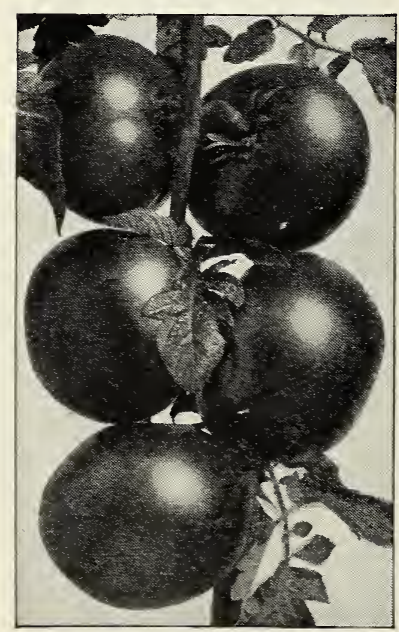

Grand Rapids Forcing

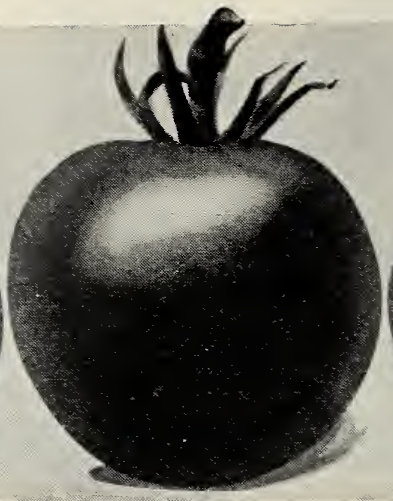

Marglobe

\section{Tomato}

One ounce produces 1,000 to 2,000 plants

Tomatoes do best on light, warm, not over-rich soil, and with a rapid, vigorous and unchecked growth early in the season. Sow in March, in rows 3 inches apart and $1 \frac{1}{2}$ inches deep, in hotbed (where 60 degrees Fahrenheit is the minimum night temperature). Cover firmly. Later sowings may be made to the end of April. When seedlings are 3 inches high, transplant to 4 inches apart each way, either in other hotbeds, in coldframes, or singly in 3-inch pots. Harden plants by exposing to the air occasionally. After warm weather is settled, set out plants 3 to 4 feet apart each way in hills. Water when transplanting and shelter from sun until established.

Bonny Best. An excellent extra-early variety with mediumsized, bright scarlet, smooth, round fruits which ripen evenly. Pkt. 10 cts.; 1/20z. 40 cts.; oz. 65 cts.; $1 / 4 \mathrm{Ib}$. $\$ 1.75$.

Earliana Selected. The fruits are deep scarlet, nearly round, very solid, with a very small core and few seeds. They mature very early and uniformly in prolific clusters near the center of the plant, and are borne on strong, vigorous vines. Pkt. 20 cts.; $1 / 2$ oz. 60 cts.; oz. $\$ 1 ; 1 / 4 \mathrm{Ib}$. $\$ 3.50$.

John Baer. A fine, extra-early, round, bright red variety, free from core, having very few seeds, with a mild, sweet flavor. Pkt. 10 cts.; $1 / 2$ oz. 40 cts.; oz. 65 cts.; $1 / 4$ Ib. $\$ 1.75$.

Marglobe. This is a new midseason sort, entirely immune from rust and wilt. A pure scarlet, globe-shaped Tomato, of good size and fine quality and a heavy cropper. Pkt. 20 cts.; $1 / 2$ oz. 60 cts.; oz. $\$ 1$; $1 / 4 \mathrm{Ib}$. $\$ 3.50$.

Ponderosa. Enormous fruits, frequently weighing over a pound each. They are very solid and Iuscious, with small seed-cells, deep purplish pink, oblong and slightly ribbed. Pkt. 15 cts.; $1 / 2$ oz. 50 cts.; oz. 85 cts.; $1 / 4 \mathrm{Ib}$. $\$ 2.50$.

Stone, Selected. One of the best late red canning varieties. Fruits are Iarge, solid, flattened-round, smooth, and uniform. Vines are large, strong, and very productive. Pkt. 10 cts.; $1 / 2$ oz. 40 cts.; oz. 65 cts.; $1 / 4$ Ib. $\$ 1.75$.

\section{Forcing Tomatoes}

Sorts for culitivation under glass, during winter and spring.

Grand Rapids Forcing. The intense vigor insures an immense setting of fruit. It is probably the only Tomato that is selffertilizing. Plant is a robust grower, and should be trimmed to about 6 feet in height. The fruit is a good red color of fair size, firm and meaty.

Stirling Castle. A very heavy cropper, with medium sized, smooth, round, clear red fruit of delicious flavor.

Sunrise. A fruit of fine quality, medium in size, perfectly round, and produced in characteristic long clusters. It is considered by many growers to be the best indoor Tomato.

Each, pkt. 25 cts.; $1 / 4$ oz. 75 cts.; oz. $\$ 2.50$ 


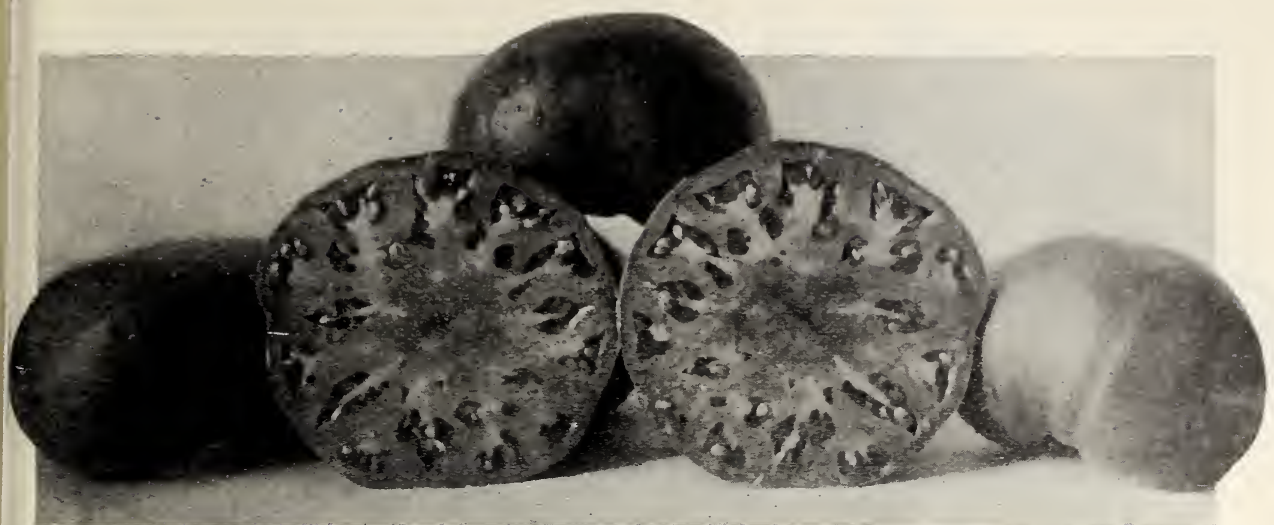

Ponderosa Tomatoes

\section{Small-Fruiting Tomatoes}

The fruits of these are much used for making fancy pickles, preserves, etc., while their size, shape, color, and flavor make them desirable additions to salads. The plants are extremely vigorous and very productive.

Italian Red Plum. In shape and size, this is suggestive of a hen's egg. The fruits are bright scarlet, are very solid and are produced in enormous clusters.

Red Cherry. Small fruits; used for pickles; very handsome.

Red Currant. Very small fruits; for preserves.

Red Peach. Resembling a peach; for preserves, pickles and an excellent variety for exhibition.

Red Pear. Fruit handsome and solid; frne for preserves.

Red Plum. Bright red, round, regular; for pickles.

Strawberry or Husk Tomato. The plants are of dwarf, spready growth and very productive. The fruit is yellow, about the size of a good-sized strawberry, and is enclosed in a husk. Yellow Cherry. For pickles and preserves.

Yellow Peach. Beautiful clear yellow; resembles a peach.

Yellow Pear. Handsome yellow, pear-shaped fruits.

Yellow Plum. Round and regular; bright yellow.

Each, pkt. $15 \mathrm{cts}$; $1 / 20 \mathrm{z}$. $45 \mathrm{cts}$. $0 \mathrm{z} .75 \mathrm{cts}$.

\section{Turnip}

\section{One ounce will sow 200 feet of row}

Turnips grow well in early spring and also in fall. They will not succeed in hot weather. The spring crop is raised from seed sown right after frost; these should be ready before June 15. After that time they are apt to be too strongly flavored. The fall crops (and these are the most important) are sown during August and September. The soil should be thoroughly worked, moderately rich, and cultivation frequent. Thin from 3 to 4 inches, according to variety. Those required for winter use may be stored in a cool cellar, covering the roots with sand.

Early White Milan. An early Turnip with clear white, very smooth, flat, symmetrical roots. The flesh is white and tender. Pkt. 10 cts.; oz. 25 cts.; 1/1/ Ib. 65 cts.; Ib. \$1.75.

Purple-Top White Globe. The globe-shaped roots are Iarge, white below the ground and purple above; flesh white, and tender. The dark green leaves are broad. Pkt. 10 cts.; oz. 20 cts.; $1 / 4$ Ib. 50 cts.; Ib. $\$ 1.50$.

Snowball, Early. Quick-growing, early, with medium-sized, round, smooth, white roots, and scant top; flesh white and tender. Pkt. 10 cts.; oz. 20 cts.; $1 / 4$ Ib. 50 cts.; Ib. $\$ 1.50$.

Yellow Globe Green-Top. Yellow-fleshed, globe-shaped, smooth roots of medium to large size, and light yellow color with small green crown. The flesh is fine-grained, and sweet. Pkt. 10 cts.; oz. 20 cts.; 1/4Ib. 50 cts.; Ib. $\$ 1.50$.

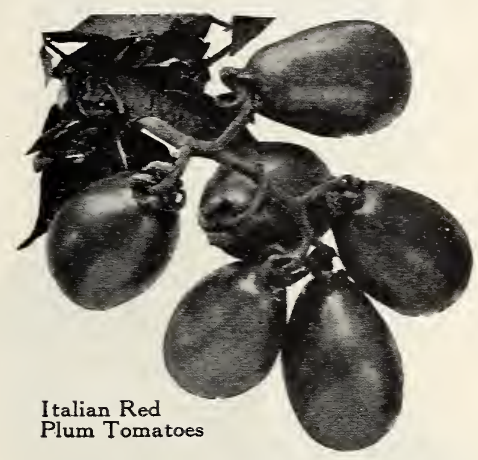

A loose fertile soil is needed to mature early Turnips rapidly and to avoid the bitter flavor which develops when the growth is checked.

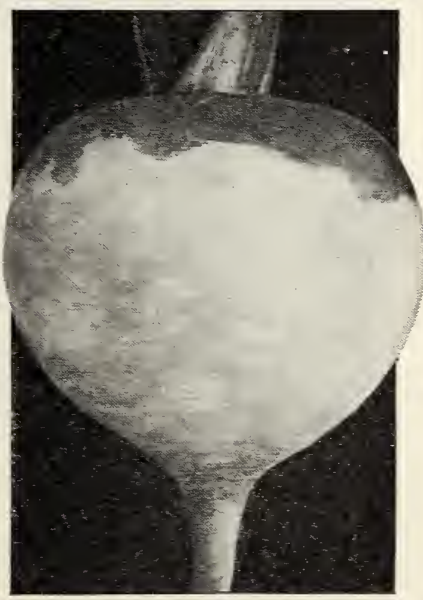

Purple-Top White Globe Turnip 


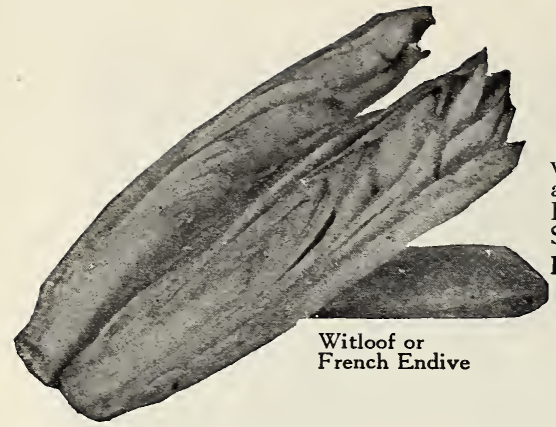

Watermelons can be grown in this latitude if conditions are favorable. This means a rich sandy soil which warms up quickly and lots of hot sun and water. The vines need plenty of room to spread and should not be lifted.

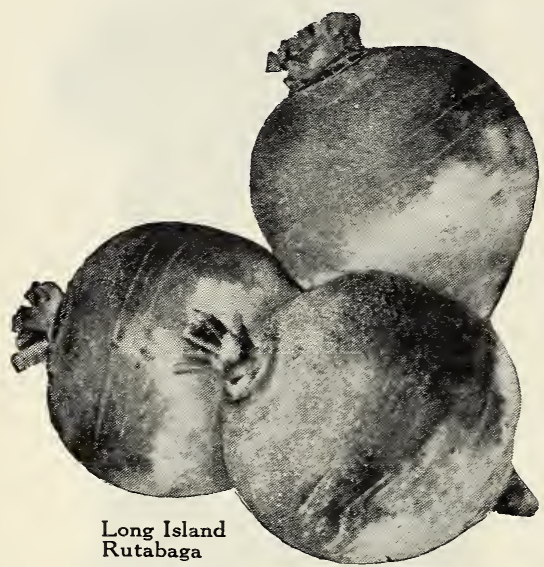

\section{Rutabaga}

One ounce will sow 200 feet of row

Sow thinly in July, in rows 2 to $21 / 2$ feet apart; cover firmly with $1 / 2$ inch of fine soil. Thin plants to stand 4 to 6 inches apart in the row. Give constant cultivation during growth. Before hard freezing weather, pull the roots and cut off tops. Store in cool cellar where it is not too dry and cover with sand. Long Island Improved. The very finest purple-top Swede Turnip grown. Roots are globular, pale yellow with a purple top and have smaller foliage and a much shorter neck than any other variety. This is the best sort for keeping. Pkt. 10 cts.; oz. 20 cts.; 1/4lb. 45 cts.; Ib. $\$ 1.25$.

\section{Watermelon}

A rich soil is necessary and the hills should be 8 feet apart each way. In warm, sandy soils, fine crops are often obtained, if plantings are made in May. Plant eight to ten seeds to the hill, covering with 1 inch of soil. When plants form first leaves thin to three plants to the hill. At the appearance of insect attack, dust freely with Slug-Shot.

Colorado Preserving Citron. Medium-sized, round, dark green fruits, marbled with light green. Pkt. 10 cts.; oz. 30 cts.; $1 / 4 \mathrm{Ib}$. 75 cts.; Ib. $\$ 2$.

Harris' Earliest. An extra-early melon of excellent quality. Slightly oval, with irregularly mottled broad stripes of light and dark green. Flesh bright red, sweet, and crisp. Pkt. 10 cts.; oz. 30 cts.; $1 / 4$ lb. 75 cts.; Ib. $\$ 2$.

Kleckley's Sweets. The vines are vigorous and productive with medium to large oblong fruits, tapering slightly toward the stem end and dark green. The flesh is very bright, rich red and exceedingly sweet, crisp, and tender. Pkt. 10 cts.; oz. 30 cts.; $1 / 4$ lb. 75 cts.; Ib. $\$ 2$.

\section{Witloof or French Endive}

Sow seed in the open ground in a light rich soil not Iater than June, in rows 12 to 18 inches apart, thinning out plants to 8 inches apart. The plant forms long, parsnip-shaped roots. Lift these in the fall, cutting off leaves $11 / 2$ inches above the neck and store in a cool place until wanted for forcing. Sort the roots according to size. PIant roots in a trench 18 inches deep and place upright, about 2 inches apart so that the neck of the root is 9 inches below the trench-level. Cover roots with a light soil, muck, or peat. For quicker growth, use fresh horse manure, about 2 feet deep, for bottom heat, cover manure with 8 inches of soil, then plant roots. It requires about a month to force the roots, and the heads, called French Endive, are excellent. Pkt. 15 cts.; oz. 40 cts.; $1 / 4 \mathrm{Ib}$. $\$ 1.25$.

\section{Vegetable Plants}

For the convenience of those who prefer using plants and those who have been too late to start their gardens from seed, we offer well-rooted, sturdy plants, grown under glass.

These are flat-grown plants, the Tomatoes ready about May 1, the Eggplants and Peppers about May 15, and the others about April 15. There are approximately 60 plants in a flat of Eggplants, 80 in a flat of Peppers, 90 in a flat of Cauliflower, and 100 in each flat of the other kinds.

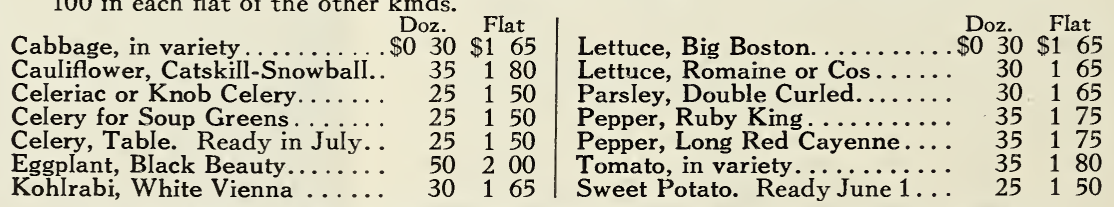

We can also supply pot-grown plants of Eggplant, Pepper, and Tomato from 2 to 21/4-inch pots, ready about May 15, for $\$ 1$ per doz.; $\$ 7.50$ per 100 . (See page 119 for flower plants.) 


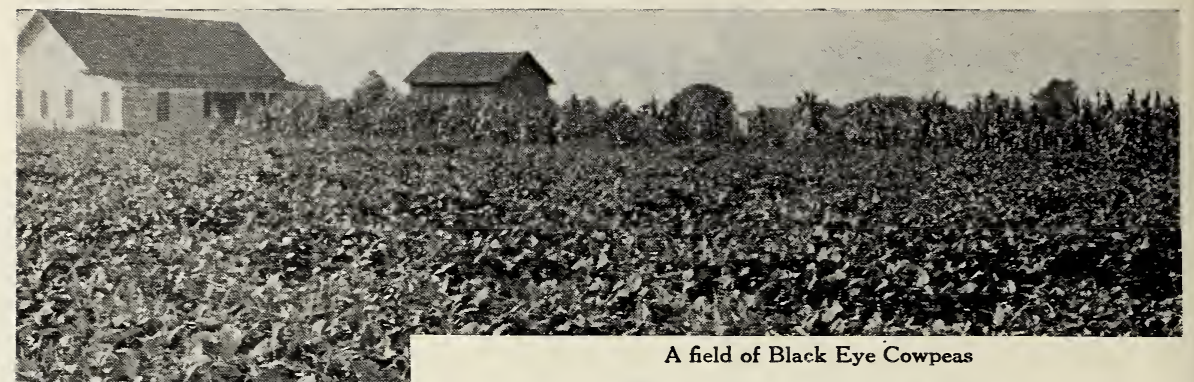

Peas (One bushel weighs $60 \mathrm{lbs}$.)

Canada White Field. These may be grown for grain, green forage, cured hay, or pasture, and have an exceedingly high feeding value. Canada Field Peas are great soil-improvers, adding nitrogen and putting the land in better condition. For plowing under as a green manure, no crop is of more importance. Sow 18 J Ibs. to the acre. $10 \mathrm{lbs}$. \$1; $100 \mathrm{Ibs} . \$ 9$.

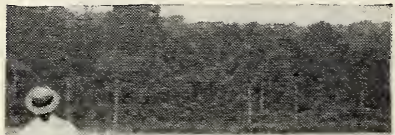

Cowpeas, Black Eye. This crop is used to improve wornout soils and make good land more productive. Grown extensively for forage but more largely for green fertilizing purposes, adding nitrogen to the soil. Extremely valuable as an enricher, and stands heat and sunshine remarkably well. Sow 120 Ibs. to the acre. 10 Ibs. $\$ 1.40 ; 100$ Ibs. $\$ 12$.

\section{Rape (One bushel weighs 50 lbs.)}

Dwarf Essex. Extremely valuable as a soil-enricher, also as a pasture crop. In the northern states it should be sown from April to end of August for fall pasture, but as it thrives best in cool weather, it should not be sown in the South until September or October for winter pasture. Sow in drills, 2 to 3 Ibs. to the acre; broadcast, 4 to $5 \mathrm{Ibs}$. to the acre. Lb. 25 cts.; 10 Ibs. $\$ 1.75 ; 100$ Ibs. $\$ 12.50$.

\section{Rye (One bushel weighs 56 lbs.)}

Spring. Catch-crop where fall-sown grain has been winterkilled; also for fodder and grain. Sow 100 lbs. to the acre. Lb. 10 cts.; 5 Ibs. 45 cts.; 10 Ibs. 85 cts.; 100 Ibs. \$7.50.

Winter. This is the variety used extensively for fall planting and is the old standard strain. Sow 70 to $90 \mathrm{lbs}$. to the acre. Lb. 10 cts.; 5 Ibs. 40 cts.; 10 lbs. 65 cts.; 100 lbs. $\$ 5.50$.

\section{Soy Beans (One bushel weighs $60 \mathrm{lbs}$.)}

Mammoth Yellow. The best for green fodder, ensilage, or for plowing under. A great soil-enricher adding humus, and extracting nitrogen from the air. A combination of twothirds Japanese Millet and one-third Soja Beans gives a perfectly balanced ensilage. 10 Ibs. 90 cts.; 100 Ibs. \$8.

\section{Vetches (One bushel weighs $60 \mathrm{lbs}$.)}

Winter, Hairy, or Sand. The branches are from 3 to 6 feet Iong, covered with fine hairs. It is extremely hardy. Sowings may be made from August 15 to October 1 , or in the spring from April 15 to May 15. For fall sowings we advise mixing with Mammoth Red Clover or Rye, these giving a support for the vines. Sow, if alone, 60 Ibs. to the acre; or with Rye, 45 Ibs. of Vetch and 30 Ibs. of Rye to the acre. Lb. 30 cts.; 10 Ibs. $\$ 2.50 ; 100$ Ibs. $\$ 20$.

Spring or Tares. Grown for soiling, or sown with oats for feeding green. Sow, if alone, $100 \mathrm{Ibs}$. to the acre. Lb. 20 cts.; 10 Ibs. \$1.50; 100 Ibs. \$10.

\section{Wheat (One bushel weighs $60 \mathrm{lbs}$.)}

Spring. Can supply standard varieties from the finest pedigreed strains. Sow 90 Ibs. per acre. 10 Ibs. \$1; 100 Ibs. \$8. Winter. AII of the standard sorts. 10 lbs. 90 cts.; 100 Ibs. \$7. 


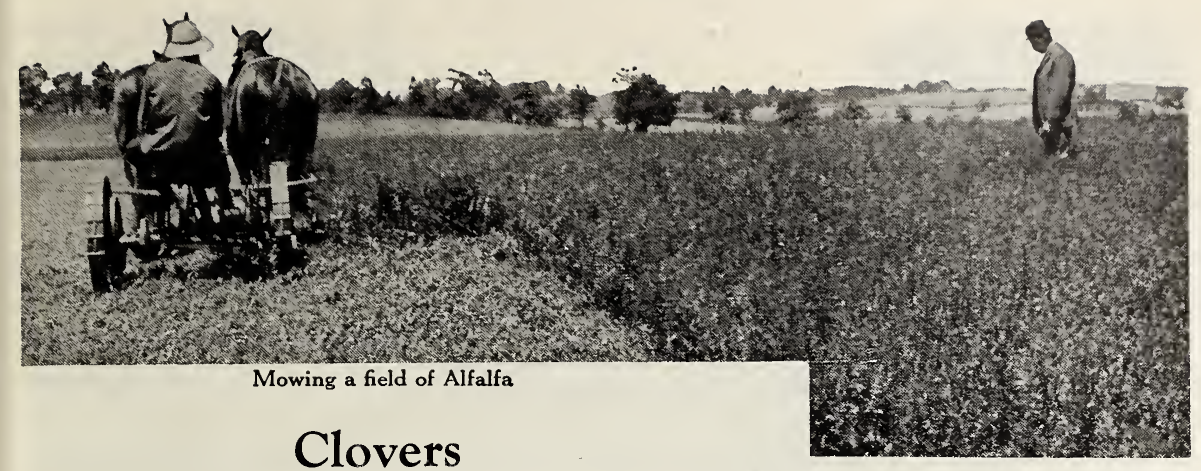

We offer only the best grades of Clovers and will gladly submit samples and current prices at your request. Please compare our quality when you consider any other offers.

The prices below are subject to market changes, f. o. b. Newark, N. J.; bags extra

Alfalfa. When once established AIfaIfa has no equal as a hayproducer-three to four cuttings in a season-the yield averaging from 4 to 6 tons per acre. It is a true leguminous perennial and sends long taproots down into the subsoil. It is one of the best forage crops and is extremely valuable as a soil-enricher. Sow from 20 to 30 lbs. per acre. Weighs 60 lbs. to the bushel. Lb. 55 cts.; 100 Ibs. $\$ 40$.

Alsike or Swedish. The hardiest of aII and stands freezing. It is very nutritious and good for either green forage, pasture, or hay. It is used largely for sowing with other grasses and Clovers, forming a thick bottom and increasing the hay-yield. Sow, if alone, 8 lbs. per acre; if used with Red Clover and Timothy seed, add 2 to 3 Ibs. per acre. Weighs 60 lbs. to the bushel. Lb. 60 cts.; 100 Ibs. $\$ 45$.

Bokhara (Sweet White-flowering). Flowers from June to September; 4 feet high. Fine for bees. Sow 10 Ibs. to the acre. Weighs 60 lbs. to the bushel. Lb. 30 cts.; 10 Ibs. $\$ 2.50$.

Crimson or Scarlet. Used for green forage and as a cover crop and soil-renovator. It is an excellent nitrogen provider and yields 2 to 3 tons of hay per acre. Can be sown in late summer and plowed under next spring. Use $15 \mathrm{Ibs}$. to the acre, either broadcast or drilled, and cover lightly. Weighs 60 Ibs. to the bushel. Lb. 40 cts.; 100 Ibs. $\$ 25$.

Grimm Alfalfa. Withstands low temperatures and cuts with greater safety in the faIl than any other sort. Has Iarger crowns, more spreading root system. and yields heavier. Will thrive in undrained wet locations. Sow 20 lbs. per acre. Weighs 60 Ibs. to the bushel. Lb. 80 cts.; 100 Ibs. \$65.

Hubam. A very vigorous, rapid-growing annual Sweet Clover. Is hardy in any climate. Valuable as a hay crop and for green manuring as it grows 4 feet high. Sow 15 Ibs. per acre. Weighs 60 Ibs. to the bushel. Lb. 60 cts.; 100 lbs. $\$ 45$. Mammoth Red or Pea-Vine. Larger and coarser in growth, but 2 to 3 weeks Iater than Common Red Clover. It is valuable for bringing poor soils back to good condition, and yields an enormous bulk. Sow 12 Ibs. to the acre. Weighs 60 Ibs. to the bushel. Lb. 90 cts.; 100 lbs. $\$ 75$.

Red. This does well on all soils, excepting sour, acid soils. It is biennial, growing 1 to 2 feet in height, averaging two crops per year. It yields 2 to 3 tons of cured hay per acre. If alone, sow broadcast 12 to 14 Ibs. to the acre. It is Iargely used mixed with Timothy, Orchard Grass, or Tall Oat Grass at the rate of 8 to $10 \mathrm{lbs}$. of Clover to $25 \mathrm{Ibs}$. of Timothy. Weighs 60 Ibs. to the bushel. Lb. 60 cts.; 100 Ibs. $\$ 45$.

White Clover. A very hardy creeping perennial adapted to most soils. Used for lawns as it forms a dense sward. Sow, if alone, 8 lbs. per acre; with grasses 4 Ibs. per acre. $1 / 4 \mathrm{Ib}$. 25 cts.; 1/2lb. 40 cts.; lb. 65 cts.; 10 lbs. \$6; 100 lbs. $\$ 55$.

Mixed Permanent Clover. Contains AIsike, Mammoth Red, Red and White. For green-manuring. Sow 12 Ibs. to the acre. Weighs 60 Ibs. to the bushel. Lb. 65 cts.; 100 lbs. $\$ 50$.

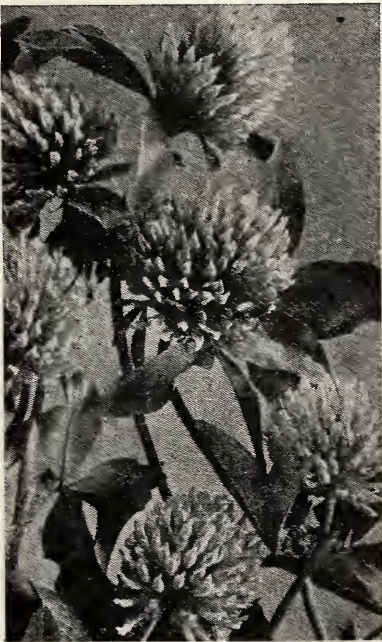

Mammoth Red Clover

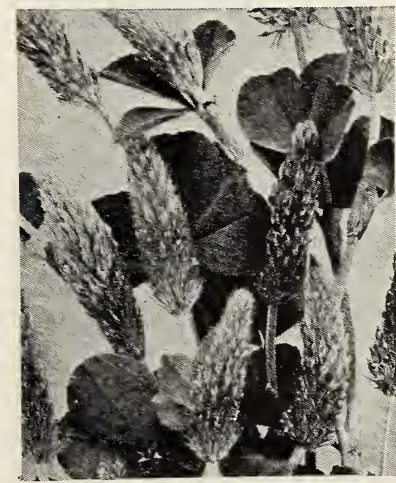

Crimson or Scarlet Clover 


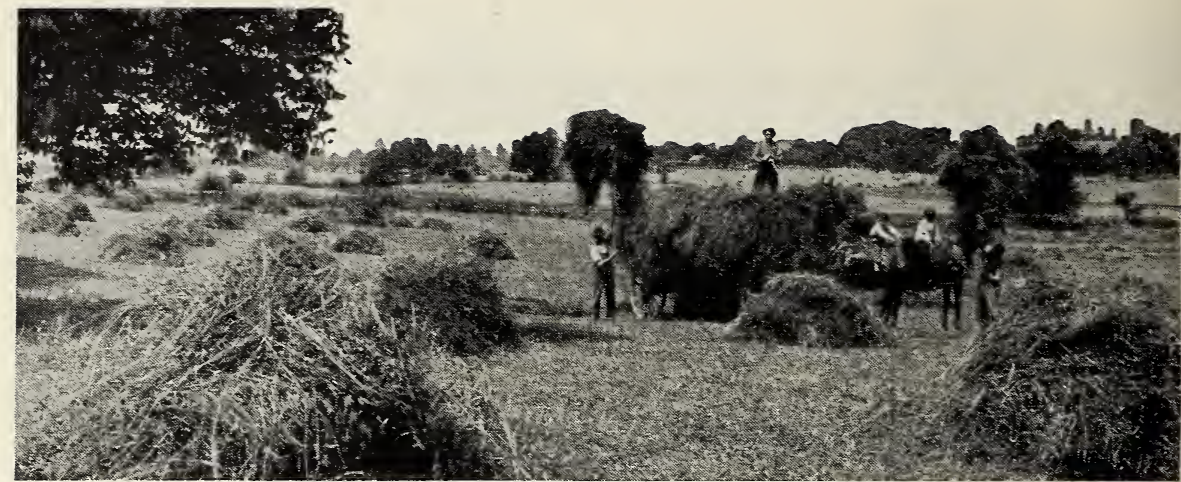

A good crop from Forbes Permanent Pasture and Hay Mixture

\section{Individual Grass Seeds}

Our Grass Seeds are obtained direct from the best original sources, are botanically true, unblended new crop, and are recleaned to the highest purity and germination.

The prices below are subject to market fluctuations, f. o. b. Newark, N. J.; bags extra

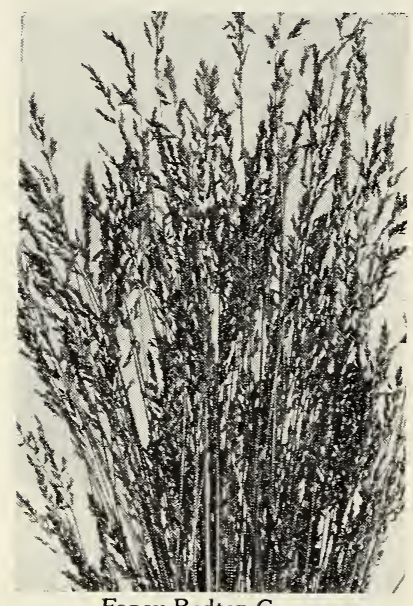

Fancy Redtop Grass

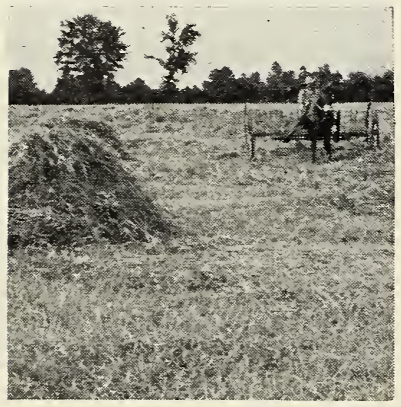

Bermuda Grass (Cynodon dactylon). Much used in the South where other grasses will not grow. A perennial of Iow, creeping habit. Helps to bind sandy soils. Sow 6 Ibs. to the acre. Lb. 70 cts.; 100 Ibs. $\$ 55$.

Canada Blue Grass (Poa compressa). A suitable grass for hard, dry soils. Excellent for rooting on steep places. Sow 42 Ibs. to the acre. Lb. 55 cts.; 100 lbs. $\$ 40$.

Creeping Bent (Agrostis stolonifera). WeII adapted for most scils. Makes thick velvety putting-greens and is very fineleaved. Sow 40 Ibs. to the acre. Lb. $\$ 1.50 ; 100$ Ibs. $\$ 110$.

Crested Dog's-tail (Cynosurus cristatus). A fine short grass for dry, exposed soils, is hardy and withstands extremes. Sow 32 Ibs. to the acre. Lb. 75 cts.; 100 Ibs. \$65.

English Ryegrass (Lolium perenne). Invaluable for permanent pastures, as it forms compact sward, remains bright and green throughout the season, and is a rapid grower. Sow 60 Ibs. to the acre. L.b. 35 cts.; 100 Ibs. $\$ 25$.

Fine-leaved Sheep's Fescue (Festuca ovina tenuifolia). The leaves are small, wire-like, very fine but tough and stiff. The color is beautiful dark green. Valuable for lawns subjected to hard wear, tees, and putting-greens. Sow 30 Ibs. to the acre. Lb. 85 cts.; 100 Ibs. $\$ 75$.

Hard Fescue (Festuca duriuscula). A dwarf-growing, early, very hardy, robust grass, succeeding well in dry soils. Sow 30 Ibs. to the acre. Lb. 55 cts.; 100 Ibs. $\$ 40$.

Italian Ryegrass (Lolium italicum). Thrives on any good soil and is unequaled for producing feed early in the spring as weIl as throughout the season. Responds quickly to rich food and moisture and is a rapid grower. Sow 50 Ibs. to the acre. Lb. 30 cts.; 100 Ibs. \$20.

Kentucky Blue Grass (Poa pratensis). This is suited to a variety of soils and is largely used as a pasture grass. It is unusually early, and presents a beautiful green appearance in early spring when other grasses are still dormant. Sow 60 Ibs. to the acre. Lb. 65 cts.; 100 Ibs. \$50.

Meadow Fescue (Festuca pratensis). One of the finest annual grasses for permanent pastures, highly nutritious and relished by stock. Succeeds well in all soils but best on moist Iand. Robust in habit and grows over a long season. Sow 50 to 70 Ibs. to the acre. Lb. 60 cts.; 100 Ibs. $\$ 45$.

Meadow Foxtail (Alopecurus pratensis). It withstands close cropping better than most other grasses, and is fine for sheep-pastures, reviving quickly after long droughts. Sow 20 to 30 Ibs. to the acre. Lb. 90 cts.; 100 Ibs. $\$ 75$. 


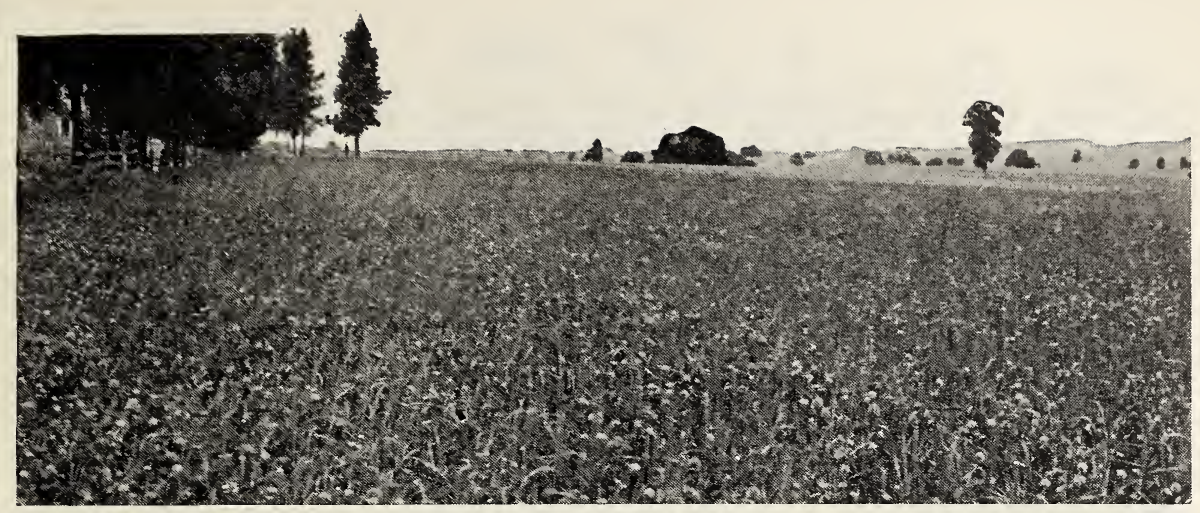

Field of Timothy and Alsike Clover

\section{Individual Grass Seeds}

Orchard Grass (Dactylis glomerata). This grass is highly valuable on account of its earliness and rapidity of growth. Succeeds on any soil, especially in moist, shady places. As it is inclined to grow in tufts it should be sown very evenly. Sow 50 Ibs. to the acre. Lb. 40 cts.; 100 Ibs. $\$ 30$.

Red Fescue (Festuca rubra). This is of creeping habit and withstands severe droughts. It roots rapidly and remains fresh and green under trying conditions. Adapted for dry pasture and on loose, light soils, embankments, etc. Sow 35 Ibs. to the acre. Lb. 60 cts.; 100 Ibs. $\$ 45$.

Redtop Fancy (Agrostis palustris). This grass is used for mixing in hay or permanent pasture and does best in a moist, rich soil where it attains a height of $21 / 2$ feet. We offer only the best quality of recleaned seeds, free from chaff. Sow 32 Ibs. to the acre. Lb. 50 cts.; 100 Ibs. $\$ 40$.

Rough-stalked Meadow (Poa trivialis). A spreading, thickly matting, stoloniferous-rooted species; leaf blades narrow, flat and dark green. Forms a fine turf; adapted for shady situation on fairways under trees. Thrives on moist and stiff clay lands. Lb. 85 cts.; 100 Ibs. $\$ 70$.

Sheep's Fescue (Festuca ovina). This short, dense-growing grass has an excellent nutritive value which offsets its lack of bulk. Excellent for upland or dry pasture. It has fine foliage and compact habit and is suitable for lawn mixtures. Sow 30 Ibs. to the acre. Lb. 55 cts.; 100 Ibs. $\$ 40$.

Sudan Grass (Sorgbum $S p$.). The finest hay and forage crop for dry sections. It is an annual and is killed by frost each year. It attains 4 to 5 feet in height, and makes an excellent hay. Sow 15 to 20 Ibs. to the acre. Lb. 35 cts.; 100 Ibs. $\$ 25$.

Tall Fescue (Festuca elatior). A coarse-growing grass adapted to moist, stiff, clay soils and shady woods, making fine hay. Sow 35 lbs. to the acre. Lb. 70 cts.; 100 Ibs. $\$ 60$.

Tall Meadow Oat Grass (Avena elatior). It is hardy and can endure extreme temperatures; best on a sandy soil. Sow 50 Ibs. to the acre. Lb. 45 cts.; 100 Ibs. $\$ 40$.

Timothy (Pbleum pratense). This perennial grass, 4 feet high, thrives in moist, Ioamy soils. Sow 40 lbs. to the acre. Lb. 25 cts.; 100 Ibs. $\$ 15$. (A bushel weighs 45 Ibs.)

Wood Meadow Grass (Poa nemoralis). Fine for shade. Makes good sod. Sow 28 lbs. per acre. Lb. 90 cts.; 100 lbs. $\$ 75$.

\section{Permanent Pasture and Hay Mixture}

A mixture of varieties which will form a permanent pasture that lasts for years. Composed of native and acclimated grasses, which have been found to be best. These are blended in their proper proportions. Sow on new Iand which has been plowed and harrowed, at the rate of 50 Ibs. per acre; on ground partly covered, about 30 Ibs. per acre. Lb. 45 cts.; 10 lbs. $\$ 4 ; 100$ Ibs. $\$ 35$, transportation charges prepaid.

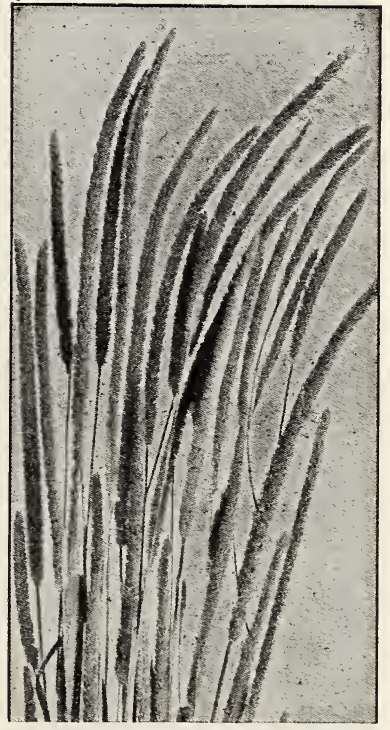

Timothy

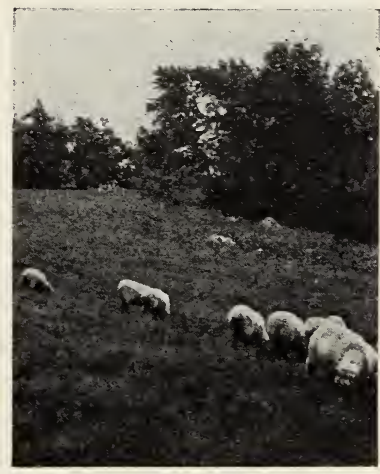




\section{Field Corn}

Plant on well-drained land as soon as nights are warm. For the Flint varieties space the hills 3 by 3 feet, for the larger Dent sorts 4 by 4 feet. 15 Ibs. will plant an acre.

A bushel weighs $56 \mathrm{lbs}$. The prices below are all f. o. b. Newark, N. J.; bags extra

\section{Dent Varieties}

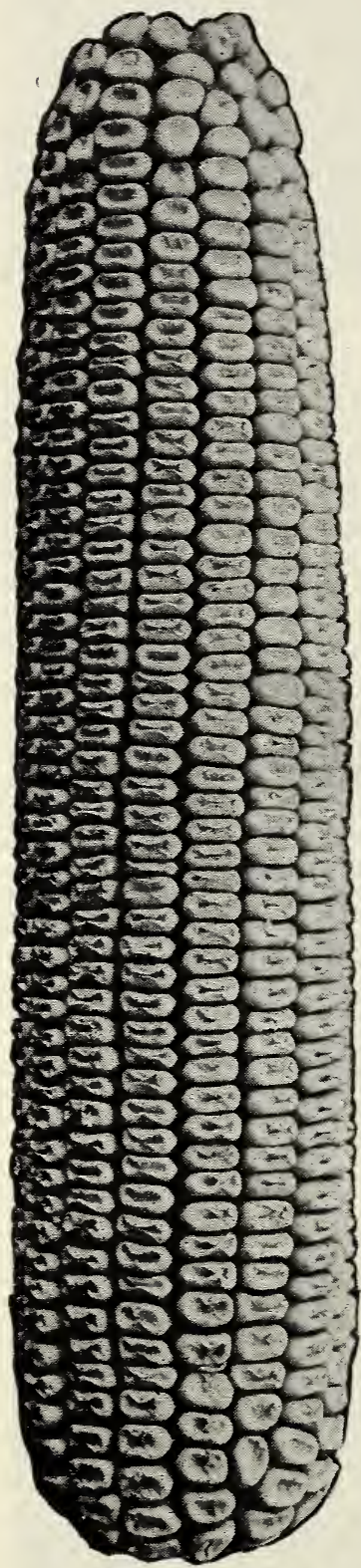

Droughtproof Dent Corn

Droughtproof. This is an early Yellow Dent of great merit, which originated in Ohio. The introducer claims: "It is the largest grained and has the smallest cob of any Yellow Dent Corn. Brightest colored grain. Fully as early as Leaming. Yield not excelled by any other sort. Strong growth of stalk and handsome ear. An unusual yield of shelled Corn insured by depth of grain." It withstands drought better than other varieties. AlI points considered, it is the best 90 to 100 -day Corn on the market.

Eureka, Yellow. An early, large-eared Yellow Dent Corn; grains are very deep, good orange color; cob smaII; matures early, a week or 10 days later than the Learning. Productive.

GoIden Beauty. A broad-grained, large-eared variety, maturing in about 120 days. Cob is small; grain very heavy and beautiful golden yellow. Very popular in New Jersey.

Leaming. Very early and prolific; ears of good size, grain of good golden color, very heavy; popular for ensilage purposes.

\section{Flint Varieties}

Canada Yellow. OId but still popular. Matures in 90 days, and is always reliable. Ears are of good length, containing eight rows of Iarge, yellow grains. Also grows a good fodder. Grows on poor land; heavy cropper.

Large White. Large, early, handsome, filled ears; grain white.

Longfellow. The longest ear of all the Yellow Flint sorts; will ripen as far north as Massachusetts.

Prices on all Dent and Flint Field Corn varieties,

lb. 20 cts.; 10 lbs. $\$ 1.50 ; 100$ lbs. $\$ 10$

\section{Ensilage Corn}

Luce's Favorite. A hybrid 8-rowed Yellow Dent, but shows mixture of Flint types. Very largely used in the dairy districts. Not recommended as a producer of Corn for husking, but as an ensilage Corn. The stalks will leaf heavily from the ground up. Use about 25 Ibs. in drills for an acre. L.b. 20 cts.; 10 Ibs. $\$ 1.50 ; 100$ Ibs. $\$ 10$.

\section{Sweet Fodder Corn}

For feeding and cuiting in summer, this provides a most satisfactory fodder. Every part of the plant above ground is digestible; so for an economical fodder and increaser of milkflow there is none better. Sow broadcast, 100 Ibs. per acre. Lb. 20 cts.; 10 Ibs. $\$ 1.50 ; 100$ Ibs. $\$ 10$. (A bushel weighs about 50 lbs.)

\section{Mangel and Sugar Beet}

Used for stock and chicken feed. Sow in rows 3 feet apart, from May 15 to June 15; thin out to 6 inches apart and cultivate freely. Use 8 to 12 Ibs. of seed per acre.

Mangel, Golden Tankard. Quite Iarge and of cylindrical shape. The skin is deep orange-red and the flesh is zoned with yellow and white and is very nutritious. $1 / 4 \mathrm{Ib}$. $30 \mathrm{cts}$.; Ib. 85 cts.; 100 Ibs. $\$ 65$.

Mangel, Mammoth Long Red. The largest of all the Mangels. The root is 15 to 18 inches long, over 6 inches in diameter, and with a heavy shoulder. It grows one-half above ground and is easily pulled. 1/4 Ib. 30 cts.; Ib. 85 cts.; 100 Ibs. $\$ 65$.

Sugar Beet, Giant Half-Sugar Rose. Very large, smcoth, and clean, of oval shape. The skin is rose-white with a deeper rose-colored top. The flesh is white and of high nutritive value. $1 / 4 \mathrm{Ib}$. 30 cts.; Ib. 85 cts.; $100 \mathrm{lbs}$. $\$ 65$.

Sugar Beet, Vilmorin's Improved. The highest in nutritive value and percentage of sugar. A large, smooth, tapering white root. $1 / 4$ Ib. 30 cts.; Ib. 85 cts.; 100 Ibs. $\$ 65$. 


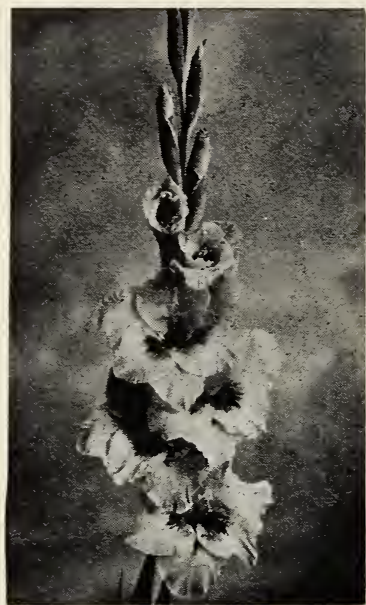

Mrs. Fred C. Peters

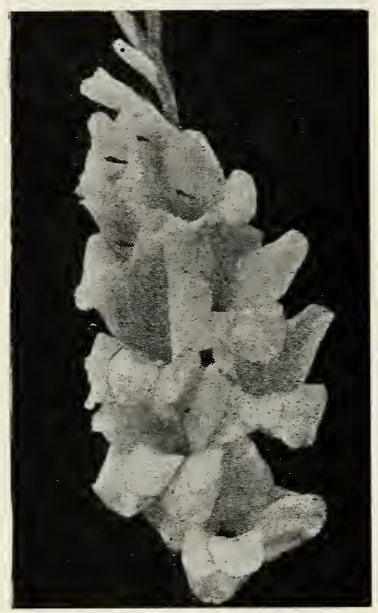

Prince of Wales

\section{Forbes Gladiolus Bulbs}

Lustre. Orange-vermilion, suffused crimson; Iarge, wide-open flowers. 20 cts. each; $\$ 2$ per doz.; $\$ 15$ per 100 .

Miss Madison. Purest deep pink, self-color; very Iarge, wideopen flowers, many open at a time. Strong, long stems. 25 cts. each; $\$ 2.50$ per doz.; $\$ 20$ per 100 .

Mona Lisa. Pure self-colored pale rose-pink almost blushwhite. 15 cts. each; $\$ 1.50$ per doz.; $\$ 10$ per 100 .

Mrs. Dr. Norton. Silvery white base, tinged with pink, which deepens toward the edges; creamy blotches in throat on lower petals. 15 cts. each; $\$ 1.50$ per doz.; $\$ 10$ per 100 .

Mrs. Francis King. Flame-red, shaded salmon toward throat. Very tall. 10 cts. each; 75 cts. per doz.; \$5 per 100.

Mrs. Frank Pendleton. Lovely flushed salmon-pink with brilliant carmine blotches in throat. $10 \mathrm{cts}$. each; $75 \mathrm{cts}$. per doz.; $\$ 5$ per 100.

Mrs. Fred C. Peters. Fine lilac-pink, with purplish blotch in throat. Many large flowers open at a time on long, erect stems. 20 cts. each; \$2 per doz.; \$15 per 100 .

Mrs. Leon Douglas. Begonia-rose, striped with flame-scarlet, lower petal pale lemon, speckled ruby. Tremendously Iarge flowers, many open at a time. Very tall, strong stem with several side-shoots, the whole forming a gigantic bouquet. 25 cts. each; $\$ 2.50$ per doz.; $\$ 20$ per 100 .

Muriel. Beautiful pure lilac-blue, with deeper blotch in throat on lower petals. Many perfectly placed flowers open at a time on tall, erect stems. A rare beauty. 20 cts. each; $\$ 2$ per doz.; $\$ 15$ per 100 .

Niagara. Primrose-yellow, splashed and striped with bright pink. Large flowers on strong spikes. 15 cts. each; $\$ 1.25$ per doz.; $\$ 8$ per 100 .

1910 Rose. A good deep pink with a fine white stripe on lower petal. 15 cts. each; $\$ 1.25$ per doz.; \$8 per 100 .

Peace. Large; pure white, feathered with pale lilac. 10 cts. each; 75 cts. per doz.; \$5 per 100.

Pink Wonder. La-France-pink, shading to pale pink in the throat, with yellow reflex at the base of the lower petals; immense blooms. 15 cts. each; $\$ 1.25$ per doz.; $\$ 8$ per 100 .

Prince of Wales. Delicate salmon-pink, lighter toward the center; well-shaped flowers on long stems. The earliest to bloom. 15 cts. each; $\$ 1.25$ per doz.; \$8 per 100 .

Schwaben. Light yellow with little red stripes on Iower petals. Strong grower with Iarge flowers and sturdy stems. $10 \mathrm{cts}$. each; \$1 per doz.; \$6 per 100.

Venus. Creamy white, suffused with flesh-pink and with yeIlow reflex on lower petals. Very delicate and a splendid early cut-flower. 15 cts. each; \$1.25 per doz.; \$8 per 100 .

Virginia. Large, massive, flaming scarlet flowers, many open at a time, making a gorgeous display of dazzling red. Good forcer. 15 cts. each; $\$ 1.25$ per doz.; $\$ 8$ per 100 .

Wilbrinck. Flesh-pink, with yellowish blotch on lower petals. Large, well-placed flowers on tall, strong stems. Blooms very early. 15 cts. each; $\$ 1.25$ per doz.; $\$ 8$ per 100 .

\section{Forbes Rainbow Gladiolus Mixture}

Plan now for a rainbow display of Gladiolus in this year's garden. These wonderful summer flowers, with their wide color range, will brighten your borders from July until frost. Easily grown and thrive in any garden soil. Forbes famous Rainbow Gladiolus Mixture is especially prepared from largest-sized bulbs of five distinct named varieties of five different shades of color. This is far superior to ordinary commercial bulb mixtures of unknown color balance. Each 50 bulbs consists of 10 bulbs of each shade, assuring evenly distributed colors.

50 cts. for 10 bulbs; $\$ 2$ for $50 ; \$ 3.50$ per 100 ; $\$ 33$ per 1,000 


\section{Rare Gladiolus of Exceptional Merit}

For those garden-Iovers who have become better acquainted with the Gladiolus and who wish to grow blooms of unusual merit this year, we suggest these varieties. Our selection is the result of careful trials made of the latest advancement in coloring, size, and strength of stem. In these trials we have compared hundreds of the newer developments with the older, better-known sorts. We thoroughly recommend each as the outstanding variety in its class, and we know that the blooms will give you genuine satisfaction. Their wondrous beauty will exceed even the most extravagant anticipation.

ANNIE LAURIE. This is truly "the fairest that e're the sun shone on"-delicate pink, overlaid with light rose-pink, with deeper lines in the throat. Its heavily ruffled blooms have a most distinctive charm which makes this variety stand out among the most recent introductions. Its splendid, compact flower-spikes are gracefully held erect on strong stems. The buds, well spaced, open in an interesting succession, providing a long period of splendor. The mediumsized flowers are borne on stalks of medium height. $75 \mathrm{cts}$. each; \$7.50 per doz.; \$55 per 100 .

LAUGHING WATER. Beyond all question of doubt, this is the most distinctive, bright salmon-rose variety, and has very real merit. The individual flowers are very large, open wide, and are perfectly placed on strong, long stems. I.aughing Water makes a remarkable showing when planted in groups against shrubbery. The grace of the flower-spike lends added charm to the beauty of this wonderful variety. 50 cts. each; \$5 per doz.; \$35 per 100.

WABAN. The clear, glowing orange color of this beautiful Gladiolus is accentuated by the dark blotch on the petals. We consider this one of the most striking varieties so far introduced. The large flowers, particularly when massed, make a brilliant color-spot long to be remembered. Its stout stems carry the full flower-spikes well. 35 cts. each; $\$ 3.50$ per doz.; $\$ 25$ per 100 .

\section{Some Very Choice Ruffled Varieties}

The ruffled petals give the flowers of this class exceptional beauty. The varieties below have unusually large blooms.

Joe Coleman. Vivid red, with carmine blotches. The flowers on each spike open evenly, giving a very full effect. 15 cts. each; $\$ 1.50$ per doz.; $\$ 10$ per 100 .

Marie Kunderd. Purest white, with almost invisible pink lines in center of lower petals; finely ruffled and very early. 20 cts. each; \$2 per doz.; \$15 per 100 .

Mrs. H. E. Bothin. Beautiful geranium-pink, tinted salmon, with a flaming scarlet center. This very striking color combination with the heavy ruffle of the graceful flowers is attractive. 15 cts. each; $\$ 1.50$ per doz.; $\$ 10$ per 100 .

Orange Glory. Deep orange, with carmine-blotched throat and stripes of creamy white on lower petals. The strong plants are very vigorous with strong stems, and heavily ruffled flowers. 15 cts. each; $\$ 1.50$ per doz.; \$10 per 100 .

Pride of Lancaster. Brilliant orange-salmon, with scarlet throat; beautifully ruffled flowers on tall, strong stems. 15 cts. each; $\$ 1.50$ per doz.; $\$ 10$ per 100 .

Purple Glory. Very deep rich velvety maroon, with almost black blotches. A very striking mammoth variety on tall, sturdy stems. 20 cts. each; \$2 per doz.; \$15 per 100 .

Rose Glory. Purest rose-pink, with deeper shading in the throat. The flowers are splendidly ruffled on strong spikes. 15 cts. each; $\$ 1.50$ per doz.; $\$ 10$ per 100.

Twilight. Creamy buff, edges of petals flaked pink; throat primrose-yellow and pink. Splendid ruffled variety. $20 \mathrm{cts}$. each; \$2 per doz.; \$15 per 100.

TRY THIS BOOK-_Gladiolus." By F. F. Rockwell. How to plant, breed, multiply, harvest, and store gladiolus; to judge, arrange, and keep them healthy. 96 pp. \$1.

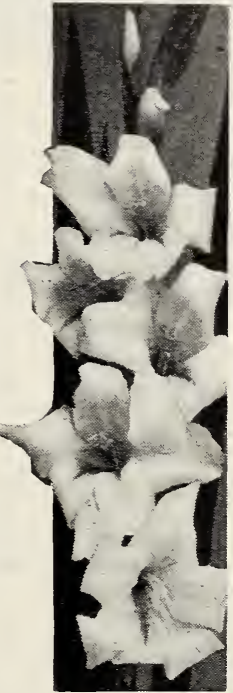

Annie Laurie

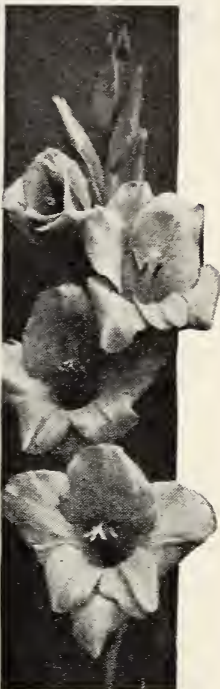

Laughing Water

The grace and charm of the Ruffled Gladiolus varieties are truly appealing.

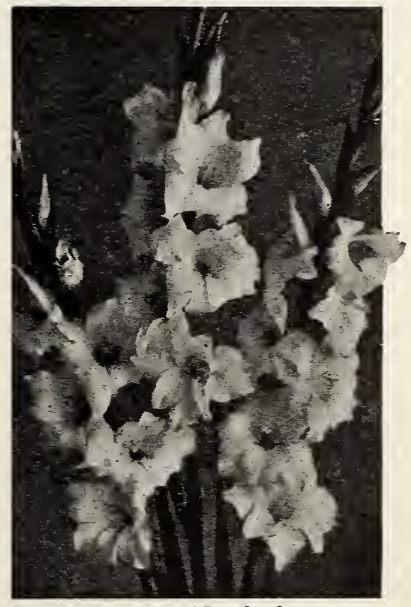

Marie Kunderd 


\section{Greenhouse Plants}

We here offer the stocks of the finest growers in the East, in healthy condition and packed to reach you in excellent shape. If any are abused in transit and are unsatisfactory when received, they may be returned, if done immediately. We send out only the choicest plants. The sizes offered are all out of $21 / 4$-inch pots, unless otherwise noted.

ASPARAGUS plumosus nanus. GracefuI, climbing plants with feathery foliage. $\$ 2$ per doz.; $\$ 12$ per 100 . Out of 3 -in. pots, $\$ 3.50$ per doz.; $\$ 25$ per 100 .

Sprengeri. An excellent variety for baskets. $\$ 2$ per doz.; $\$ 12$ per 100 . Out of 3 -in. pots, $\$ 3.50$ per doz.; $\$ 25$ per 100 .

BEGONIA, Glory of Cincinnati. A beautiful shade of pink. \$7 per doz.; \$50 per 100.

Gustav Knaake. Large flowers of rich, very deep crimson. \$3 per doz.; \$20 per 100 .

Melior. The ideal variety for Christmas. $\$ 7$ per doz.; $\$ 50$ per 100 .

Mrs. J. A. Peterson. Deep pink flowers with red foliage. $\$ 7$ per doz.; $\$ 50$ per 100.

Peerless. Red flowers with bronze foliage. $\$ 8$ per doz.; \$60 per 100 .

Rex Varieties. Assorted types. \$5 per doz.; $\$ 25$ per 100 .

BOUVARDIA, New Giant Pink. The coral-red flowers are as large as the white Humboldti. A beautiful variety for the greenhouse. $\$ 5$ per doz.; $\$ 30$ per 100 .

BUDDLEIA asiatica. Attractive white flowers. \$4 per doz.; \$30 per 100.

CALCEOLARIA grandiflora Hybrids. Large blooms in an assortment of rich colorings. $\$ 4.50$ per doz.; $\$ 30$ per 100 .

Lymani. A true cinnamon-red variety. $\$ 8$ per doz.; \$60 per 100 .

Medfordi. Beautiful flowers of rich velvety maroon. \$8 per doz.; $\$ 60$ per 100 .

Stewarti. A fine bright yellow variety. \$8 per doz.; $\$ 60$ per 100 .

CALENDULA, Orange King or Ball's. \$1.50 per doz.; \$12 per 100 .

Campfire or Sensation. A sensational colorpetals brilliant orange with scarlet sheen, with full yellow center. A fine new variety. $\$ 2.50$ per doz.; $\$ 15$ per 100 .

CHRYSANTHEMUMS. Standard named varieties. \$3 per doz.; \$20 per 100 .

CINERARIA, Half-Dwarf Hybrids. Very largeflowering, in a beautiful assortment of colors ranging from white through flesh, rose, crimson, blue and violet. Plants are medium tall. $\$ 2.50$ per doz.; $\$ 15$ per 100 .

Stellata. A highly decorative variety in colors ranging from dark blue to coral-pink. $\$ 2.50$ per doz.; \$15 per 100.

CYCLAMEN giganteum, Mixed. Assorted colors, \$4 per doz.; \$25 per 100 . Out of 3in. pots, $\$ 7$ per doz.; $\$ 50$ per 100 .

EUPHORBIA jacquiniæflora. A real fine strain, with well-colored red-orange flowers. \$5 per doz.; $\$ 30$ per 100.

FERNS. Assorted table varieties for ferneries and fern dishes. $\$ 2.50$ per doz.; $\$ 15$ per 100 .

FUCHSIA, Giant Pink. A wonderful pot plant with large pink and white flowers. \$3 per doz.; \$20 per 100 .

GARDENIA veitchi (Cape Jasmine). Beautiful pot plants. $\$ 5$ per doz.; $\$ 35$ per 100 . Out of 3-in. pots, $\$ 10$ per doz.; $\$ 70$ per 100 .
MARGUERITES, Mrs. F. Sanders. A double white variety. $\$ 4$ for $25 ; \$ 14$ per 100

Boston Yellow Daisy. The well-known yellow sort. \$4 for 25; \$14 per 100.

POINSETTIAS, True Oak-leaf. The improved variety. $\$ 5$ per doz.; $\$ 30$ per 100 .

PRIMULA malacoides, American Legion. Large, clear pink flower, yellow center. $\$ 2.50$ per doz.; \$15 per 100.

Lelandi. Beautiful lilac-pink flower, Iarge yellow eye. A fine variety for cutting. \$5 per doz.; $\$ 25$ per 100.

Lilac. Free-flowering; delicate lilac. $\$ 2.50$ per doz.; $\$ 15$ per 100 .

Radio. Giant-flowering; fringed; clear rose. $\$ 2.50$ per doz.; $\$ 15$ per 100 .

Primula obconica, Mueller-Mohnstein Strain. Dark pink. \$3 per doz.; \$17 per 100.

Kermesina. Large, rich deep red flowers. $\$ 2.50$ per doz.; \$15 per 100.

Lavender. Beautiful shade of delicate Iavender. $\$ 2.50$ per doz.; $\$ 15$ per 100 .

Rosea. Flowers of a fine deep rose-color. $\$ 2.50$ per doz.; $\$ 15$ per 100 .

Salmon. Strong grower; large salmon flowers. $\$ 2.50$ per doz.; $\$ 15$ per 100 .

Primula chinensis. In the same colors as above and mixed, $\$ 2.50$ per doz.; $\$ 15$ per 100 .

PYCNOSTACHYS Dawei (The Blue Beebalm). Beautiful blue winter-flowering plant. \$6 per doz.; \$40 per 100.

SMILAX. Very popular for use as a greenhouse climber. \$2.50 per doz.; \$15 per 100 .

SOLANUM, Cleveland Red. The improved Jerusalem Cherry so popular as a house plant. $\$ 2.50$ per doz.; \$15 per 100 .

Cleveland Yellow. The yellow-fruited variety. $\$ 2.50$ per doz.; $\$ 15$ per 100 .

STEVIA serrata, Double White. Fine greenhouse plant, with a profusion of flowers for cutting. $\$ 2.50$ per doz.; $\$ 15$ per 100 .

\section{Antirrhinum - Snapdragon}

One of the most widely grown plants for greenhouse flowering and outside bedding.

Geneva Pink. Pleasing glistening rose-pink. Golden Pink Queen. Superb new variety.

Helen. Beautiful light shade of salmon-pink.

Jennie Schneider. Lovely rose-pink with spikes 2 feet long. \$3 per doz.; \$20 per 100 .

Judd's New Early Dark Pink. Attractive rosepink, similar to the Premier rose.

Judd's New Early Light Pink. Magnificent pink similar to the Columbia rose.

Penn-Orange. Striking, vivid tangerine-orange, with subdued yellow and pale pink shadings.

A splendid variety. \$3 per doz.; \$20 per 100 . Orlando. Beautiful bronze-an odd color. Philadelphia Pink. The best pink variety. White Rock. Best white forcing Snapdragon. Yellow Giant. Very Iarge yellow flowers.

Plants of any of the above in season, out of 21/4-in. pots, $\$ 2.50$ per doz.; $\$ 15$ per 100, except where otherwise noted 


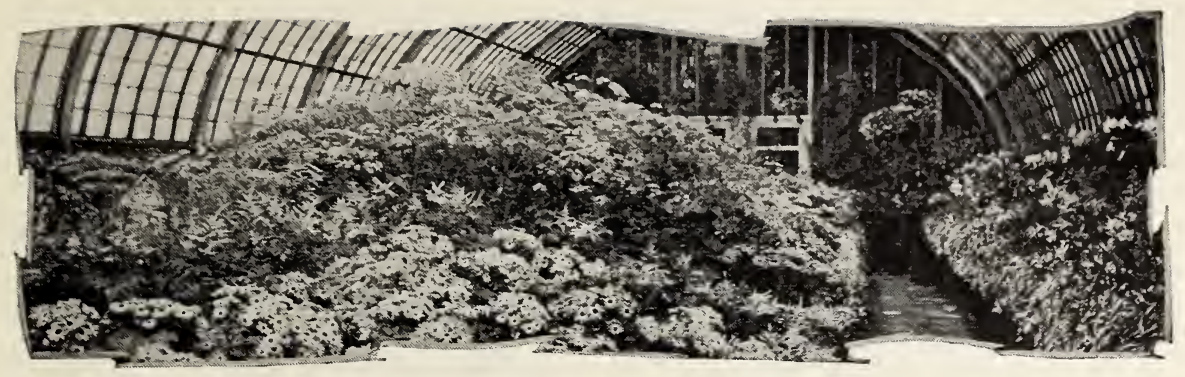

\section{Greenhouse Plants}

\section{Carnations}

A select list of both recent introductions and standard choice varieties for greenhouse culture. Dorner's Early Rose. Clear light rose-pink. Boston Ward. Fine improved dark pink. Eldora. The best variegated variety.

Johnson's Crimson. Very fine crimson.

Laddie. Salmon-rose. \$4 per doz.; \$30 per 100.

Maine Sunshine. The best clear yellow. \$4 per doz.; $\$ 30$ per 100 .

Harvester. Snow-white and free-flowering.

Matchless. Very fine white variety.

Radiolite. Brilliant scarlet.

Sceptre. Large; salmon-pink. Wonderful keeper. Sophelia. Pleasing shade of pink.

Spectrum. A magnificent Iarge scarlet.

Any of the above, except where noted, rooted cuttings for spring delivery, $\$ 3$ per doz.; $\$ 20$ per 100

\section{Hydrangeas}

This type of forcing Hydrangeas is easy to grow. The Iarge flowers are of bright color.

\section{Standard German Varieties}

Elmar. BeautifuI carmine-red.

Gudrun. Compact-growing light pink.

Helge. An exceptionally fine bright dark red.

Lancelot. Prettily fringed, deep bright pink.

Lorelei. Brilliant carmine-red.

Wilhelm Pfitzer. Free-flowering; light pink.

Any of the above, out of $21 / 4$-in. pots, $\$ 5$ per doz.

\section{Gerbera}

Jamesoni Hybrids, The Transvaal Daisy

This is one of the finest of aII winter-flowering plants for forcing. The new colors that are included in these hybrids vary from delicate fleshpink to rich scarlet, with intermediate shades of cream and orange. Their splendid 2-foot stems and large, brilliant flowers put them in the first rank of winter flowers for cutting. Strong, 2yr.-old clumps, \$12 per doz.; \$90 per 100 .

\section{Greenhouse Roses}

The Roses we offer for greenhouse culture are grown by reliable growers on grafted stock only. We guarantee fine, healthy stock will be sent on all orders entrusted to our care.

Briarcliff. True rose-pink more brilliant than Columbia, without the salmon undertones.

Double White Killarney. The best white.

Mrs. Calvin Coolidge. New golden yellow.

Mme. Butterfly. Bright pink, apricot and gold.

Premier Supreme. Rose-pink; easy grower.

Rapture. Salmon, deeper than Butterfly, with the same golden flush at the base of petals.

Souvenir de Claudius Pernet. Popular, beautiful yellow variety. $\$ 12$ per doz.; $\$ 90$ per 100 .

Talisman. The new vivid pink, orange, and gold variety. \$12 per doz.; \$90 per 100 .

Templar. Clear bright red; very fragrant.

Grafted stock only, out of $21 / 4$-in. pots, any of the above, except where noted, $\$ 8$ per doz., $\$ 60$ per 100

\section{Annual Flower Bedding Plants}

These are used largely to replace spring-flowering bulb plantings and for the planting out of large flower-beds to avoid the delay which would be caused by raising plants from seed.

These are flat-grown plants, ready about May 1 . There are approximately 80 plants in a flat of Asters and about four dozen in each flat of the other kinds.

Aster, Forbes Branching Mixed Doz. Flat

Calendula, Mixed.............. $45 \quad 165$

Cosmos, Early-flowering, Mixed... $45 \quad 165$

Marigold, Tall African, Mixed..... 45165
Marigold, Dwarf French, Mixed $\begin{gathered}\text { Doz. Flat } \\ \$ 045 \$ 165\end{gathered}$

Salvia splendens.............. 50 r. 180

Snapdragon, Super-Giant, Mixed.. $45 \quad 165$

Zinnia, Dahlia-flowered, Mixed... 45165

The following are pot-grown plants, out of 21/4-inch pots, except where noted.

Ageratum, Blue. From 4-inch puts. $\$ 500 \$ 1000$

Alyssum, Little Gem........... $150 \quad 1200$

Aster, Forbes Branching, Mixed. . $100 \quad 800$

Calendula, Orange King......... $150 \quad 1200$

Geranium, Double Rose-Pink,

Double Salmon-Pink, and

Double Red. From 4-in. pots... 5004000

Heliotrope, Lavender. 4-in. pots.. 5004000
Marigold, Tall African, Mixed . Doz. 100

Marigold, Dwarf French. Mixed . . $150 \quad 1 \quad 50 \quad 1200$

Petunia, Bedding Vars. Mixed.... $150 \quad 1200$

Petunia, Rosy Morn............ 1501200

Salvia splendens................. $150 \quad 1200$

Snapdragon, Giant Mixed........ $150 \quad 1200$

Verbena, Large-flowered, Mixed. . 1501200

Zinnia, Double-flowered, Mixed. . $150 \quad 1200$ 


\section{Garden Books}

By those who have and love gardens and by those who would love to have gardens, these books will be keenly enjoyed. Select a helpful garden book or two. If to be mailed, add 15 cts. per copy for postage.

Alpen Flowers. By L. and C. Schröter. A very useful book for identification of AIpines. Over 200 fine color illustrations. 26 plates. \$3.

Annuals of Flowerland, The. By A. T. A. Quackenbush. A charming book of the myth and love of the annual flower families and their members' pedigrees. 166 pp. $\$ 1.50$.

Annuals, The Book of. By A. C. Hottes. HelpfuI, illustrated guide to the handling of annual flowers and vines for seeding, transplanting, and pinching in. Gives the description, arrangement, use, and culture. $182 \mathrm{pp}$. $\$ 1.50$

Around the Year in the Garden. By F. F. Rockwell. Written by a practical amateur grower for the busy man or woman who must use every hour in the garden to the best advantage. 350 pages. WeII illustrated. $\$ 2.50$.

Bulbs, Book of. By F. F. Rockwell. The sorts and uses of usual and rare spring, summer, and faIl bulbs, indoors and out, including gladiolus, peony, iris, dahlia, and begonia. $272 \mathrm{pp}$. $\$ 3$.

Bulbs that Bloom in the Spring. By $T$. A. Weston. All the home gardener should know about fall bulbs for spring display. \$2.

Climbing Plants, A Little Book of. By A. C. Hottes. Cultural directions for over 100 beautiful climbers. $250 \mathrm{pp}$. $\$ 1.75$.

Dahlia Culture, Modern. By W. H. Waite. Brief, complete advice how to plant, enrich, propagate, disbud, store and show dahlias, with lists of don'ts for their health. $126 \mathrm{pp}$. $\$ 1.50$.

Dahlia, The Amateur's Book of the. By Mrs. Charles H. Stout. Practical, authoritative and charmingly written. \$3.

Design of Small Properties. By M. E. Bottomley. More than 50 examples of layouts for the general development of small city and country homes are presented. Describes trees, shrubs, vines, and flowers with directions for their planting and maintenance. 265 pp. $\$ 3$.

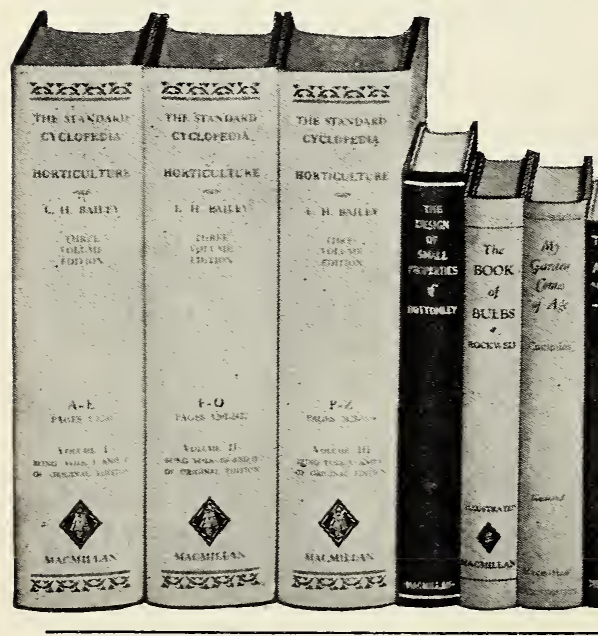

Evergreens for the Small Place. By F. F. Rockwell. Practical suggestions. Illustrated. \$1. Fertilizers. By E. B. Voorhees. The source, character, and composition of natural, homemade, and manufactured fertilizers and how to use them. 310 pp. $\$ 2.50$.

Fertilizers, Handbook of. By A. F. Gustafson. An attempt to supply accurate, up-to-date information as to the source and make-up of commercial fertilizers. Illustrated. $122 \mathrm{pp}$. \$1.25.

Flower Arrangement, Principles of. By Ed. A. White. Seasonable flowers and how to arrange them in receptacles according to the Iaws of form and color, and the art and canons of Japan. Decoration of rooms. $225 \mathrm{pp}$. $\$ 3$.

Flower Garden, The Seasons in a. By Louise Shelton. The record of an enthusiastic amateur; full of valuable information. \$2.

Flower Garden, The Practical. By Mrs. H. R. Ely. A very useful and practical book, finely illustrated, new edition, just issued. $\$ 2$.

Flower Garden, The Woman's. By J. L. Kift. Practical and interesting information on outdoor and indoor flower plants. $160 \mathrm{pp}$. $\$ 1$.

Foundation Planting. By Leonard H. Johnson. The art and science of beautifying the immediate frontage of the house with plants. Profusely illustrated. $256 \mathrm{pp}$. $\$ 3.50$.

Home Flower-Growing. By Prof. E. C. Volz. A book for the person who would grow flowers and decorative plants, at home, for pleasure. $364 \mathrm{pp}$. WeII illustrated. $\$ 3.50$.

House Plants, Milady's. By F. E. Palmer. Tells of the plants which any woman can successfully grow indoors; 100 instructive pictures. 176 pp. \$1.25.

Garden Cinderellas: How to grow lilies in the garden. By H. M. Fox. An illustrated guide for the amateur in growing all kinds of lilies successfully; their history, propagation, hygiene, with depth directions for planting. $269 \mathrm{pp}$. $\$ 5$.

Gardener, The. By L. H. Bailey. The author's latest book, giving in alphabetical order clear and concise directions for the growing of flowers, fruits, vegetables, etc., in the garden and house. A most valuable book. 260 pp. $\$ 2$.

Continued on next page

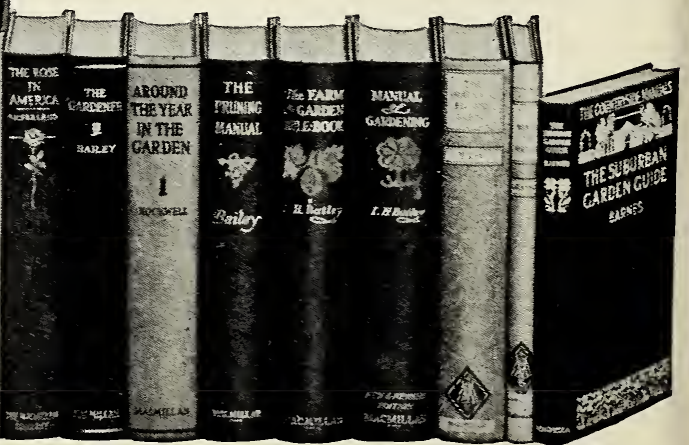




\section{Garden Books}

Garden Guide. By De La Mare. A compact book of knowledge of gardening; 30 subjects covered by eleven experts; 275 illustrations, especially good on pests. 384 pp. $\$ 1.50$.

Gardening, City and Suburban. By C. C. Sherlock. A complete aid for planning the home property, with many plans. $186 \mathrm{pp}$. \$2.

Gardening, Manual of. By L. H. Bailey. Practical work on the diseases, pests, propagation, and growing of ornamental and useful plants as well as their arrangement. 539 pp. \$3.

Gardening under Glass. By F. F. Rockwell. Written especially for the amateur and showing him how he can have fruits and vegetables of superb quality out of season, Roses and Carnations in midwinter, Palms and Ferns all the year around. IIIustrated. 289 pp. $\$ 2.50$.

Gardening with Peat Moss. By F. F. Rockwell. Peat Moss; what it is and how used for seedlings, lawns, roses, evergreens, bulbs, hardy perennials, and house plants. 72 pp. $\$ 1$.

Gladiolus. By F. F. Rockwell. How to plant, breed, multiply, harvest, and store gladiolus, to judge, arrange, and keep them healthy. $\$ 1$.

Hardy Garden, A Woman's. By Mrs. H. R. Ely. One of the most popular and helpful books for the amateur, beautifully illustrated. \$2.

Horticulture, Standard Cyclopedia of. By L. H. Bailey. Three volumes, more than 3,600 pages, covering 40,000 plant names. $\$ 25$.

Iris, The. By John C. Wister. The object of this book is to present in a clear, convincing manner to the amateur the simple requirements of this flower. IIlustrated. 128 pp. \$1.25.

Landscape Gardening. By F. A. Waugh. A simple book, stating the first principles in landscape gardening so clearly that the average amateur can understand them. \$2.

Landscape Gardening, Practical. By R. B. Cridland. Of particular value to the owner of the moderate-sized suburban home. Nicely illustrated. 280 pp. $\$ 2.50$.

Lawn Making. By Leonard Barron. Grading, making, renovating, mowing, rolling, watering, feeding, weeding, seeding; in fact deals with the subject in closest detail. $176 \mathrm{pp}$. Profusely illustrated with original photographs. \$2.

Lilies, Garden. By I. Preston. The mission of this book is to teach the amateur the art of growing garden lilies. $\$ 1.25$.

Nursery Manual, The. By L. H. Bailey. Complete guide to the multiplication of plants. $\$ 2.50$.

Ornamental Trees, The Care of. By C. F Greeves Carpenter. Interesting, compact book for the use of the owner in checking the work of the tree surgeon and help him to do his own surgery. 90 pp. $\$ 1.25$.

Perennials, The Little Book of. By A. C. Hottes. A book for the design and upkeep of herbaceous borders, rock, fern and wild gardens, with lists of plants for special uses. 200 pp. $\$ 1.50$.

Perennials, Popular Hardy. T. W. Saunders. Profusely illustrated on uses, culture, and propagation of perennials. 402 pp. $\$ 3.50$.

Plant Propagation, Practical. By A. C. Hottes. An exposition of the art of increasing plants as practiced by the florist and gardener. $\$ 2$.

Pruning, Manual of. By L. H. Bailey. Standard handbook on the principles and practice and time of pruning trees, shrubs and vines, including Baltet tables. Stops the havoc of wrong pruning. 400 pp. $\$ 2.50$.
Rock Gardens. By S. F. Hamblin. A complete treatise on making rock gardens. Selection of plants, culture and propagation. \$1.25.

Rock Gardens. By F. F. Rockwell. Tells just where and how to make a Rock Garden, what plants to use and where to put them. IIlustrated. 86 pp. $\$ 1$.

Rock Gardening, A Simple Guide to. By Sir J. L. Cotter. A practical book of rock, wall and bog-garden-making, giving method and choice of planting material and its culture. $126 \mathrm{pp}$. \$1.

Roses and Their Culture. By S. C. Hubbard. The object of this book is to present in clear and concise manner to the amateur in particular, the simple requirements of the rose. $128 \mathrm{pp}$. $\$ 1.25$.

Rose in America, The. By J. Horace McFarland. Beautifully illustrated in color and sepia, this new and enlarged edition will have an important place on every rose fancier's book shelf. 232 pp. \$3.

Roses in the Little Garden. By G. A. Stevens. Covering all phases of rose-culture, with selections for different purposes. Clear directions for planting, pruning, fertilizing, and protection from enemies. Practical and up-to-date. \$1.75.

Shrubs. By F. F. Rockwell. Excellent inexpensive book on proper shrub planting for the small house; the selection, planting and care, with lists for different purposes. $96 \mathrm{pp}$. $\$ 1$.

Shrubs, Book of. By A. C. Hottes. Where, when, and how to plant for color, flower, and fruit succession for amateur and professional; lists for special uses and tables. 371 pp. \$3.

Spraying Crops. By C. M. Weed. A treatise explaining the principles and practice of the application of liquids and powders to plants for destroying insects and fungi. \$1.25.

Spraying, Dusting, and Fumigating of Plants. By A. F. Mason. Handbook on how to identify and control pests, and to choose spray materials and sprayers. $570 \mathrm{pp}$. $\$ 5$.

1001 Garden Questions Answered. By A. C. Hottes. An up-to-date and practical book on every phase of gardening in the form of questions and answers including even such subjects as judging shows and plant breeding. 293 pp. \$2.

Turf for Golf-Courses. By Prof. Piper and Oakley. This is an authoritative and practical treatise on the production and maintenance of grass and turf. $262 \mathrm{pp}$. $\$ 2.50$.

Vegetable Gardening. By A. Kruhm. Written especially for the home garden; tells what and when to plant and how to care for them. $\$ 2$.

Water Gardens and Goldfish. By Sawyer and Perkins. How to have a small pool, water-lilies and plants, well-grown and healthy; gold-fish and how to feed, breed, and doctor them, with aquarium management. 112 pp. $\$ 1.50$.

Water-Gardening, Book of. By Peter Bisset. The history and culture of water lilies and other water plants; also the arrangement and best kinds of evergreens, shrubs, and perennials for the borders and backgrounds of pools. \$5.

Modern Aquarium. By W. T. Innes. The breeding and care of Goldfish and Tropicals. \$1.

Goldfish Varieties and Tropical Aquarium Fishes. By W. T. Innes. A complete, concise, and interesting book dealing with the various aquarium fish; their habits, care, diseases, and how to breed them. Also aquarium plants, how to build aquariums, etc. $300 \mathrm{pp}$. \$4. 


\section{Insecticides and Fungicides}

\section{Prices are subject to change without notice}

The directions for use of each of these materials will be found printed on each package. Only those items prefaced by an asterisk $\left(^{*}\right)$ may be shipped by Parcel Post.

Ansect. Has 71 per cent killing power on rose and mealy-bugs. Use 1 part to 30 to 50 parts of water. Very thorough spraying is essential. 4-oz. can 30 cts.; pt. \$1; qt. \$1.60; gal. $\$ 5 ; 5$ gals. $\$ 21$.

*Ant Killer. Effective against ants and other insects that infest lawns, but is harmless to Iawns. Sprinkle a small quantity around the ant-hills. $4 \frac{1}{2}-0 z$. can 50 cts.

Antrol. Adopted by U. S. Government as best method of ant-control in homes or gardens. The syrup attracts ants to jar; they eat it and carry it back to their nest, where queen ant eats it and entire colony is destroyed. House Sets ( 4 jars and 4 ozs. syrup) $\$ 1$. Extra jars, 20 cts. each. Syrup, 4 ozs. 60 cts.; pt. $\$ 1$; gal. $\$ 3.75$.

Aphine. Readily soluble in water, applied as a spray, wash, or dipping solution. Destroys plant lice, aphis, red spider, etc. Use from 2 to 4 tablespoonfuls to 1 quart of water according to directions. $1 / 4 \mathrm{pt}$. $25 \mathrm{cts}$.; $1 / 2 \mathrm{pt}$. 40 cts.; pt. 65 cts.; qt. \$1; gal. \$3.

*Aphistrogen. A complete spray that quickly rids your plants of aphis and plant-lice. It is invisible, non-poisonous, and will not yellow the foliage. 2 ozs. 50 cts.; $1 / 2 \mathrm{lb}$. $\$ 1.25$; Ib. $\$ 2.25 ; 2$ Ibs. $\$ 3.50 ; 12$ Ibs. $\$ 15$.

Arsenate of Lead, Dry. For spraying trees and shrubs against attacks of leaf-biting insects. It adheres to, but does not injure foliage. Remains weIl suspended in solution, insuring even distribution. Being white it shows just where it has been applied. Use $1 \mathrm{Ib}$. to 50 gals. of water. 1/2lb. 30 cts.; Ib. 50 cts.; 5 Ibs. \$2; 10 Ibs. \$3.50; 25 Ibs. \$8; 50 Ibs. \$12.

*Axfixo Tobacco Dust. A superior grade of tobacco dust particularly adapted for root crops. Acts best under hot weather conditions when a suffocating gas is given off. Lb. 50 cts.; 5 Ibs. \$2; 25 Ibs. \$7; 50 lbs. \$12.

"Black Leaf 40." An effective soluble insecticide for sucking insects such as plant lice, aphis, red spider, leaf hopper, thrip, etc. Dilute 2 teaspoonfuls to 1 gal. of water, and spray. Leaves no stain either on fruit or foliage. 1-oz. bottle 35 cts.; 1/2Ib. $\$ 1.25$; 2 Ibs. $\$ 3.50 ; 10$ lbs. $\$ 13.50$.

Bordeaux Mixture, Dry. A fungicide for mildew, blight, rust, scab, and all fungous diseases. Has double the strength of paste form. Use $1 \mathrm{Ib}$. to 5 gals. of water. $1 / 2 \mathrm{lb} .25$ cts.; Ib. 40 cts.; 5 Ibs. $\$ 1.50 ; 10$ lbs. $\$ 2.75$; 25 Ibs. $\$ 5.75 ; 50$ Ibs. $\$ 10$.

Calcium Arsenate. Known for its high arsenic content. It is probably the most effective arsenical insecticide on the market. For spraying potatoes and tobacco, and is the best remedy for cotton boll-weevil and the Mexican bean beetle. 1/2lb. 20 cts.; Ib. 35 cts.; 4 Ibs. $\$ 1.25 ; 8$ Ibs. $\$ 2 ; 25$ Ibs. $\$ 4.50 ; 50$ Ibs. \$7.

Cut-Worm Killer. Sprinkle near plants affected. Worms prefer its enticing odor to vegetation. $1 \mathrm{Ib}$. covers 100 feet of plants in rows, 175 plants in hills. Lb. 50 cts.; 5 Ibs. $\$ 2 ; 25$ Ibs. $\$ 5.50 ; 100$ Ibs. $\$ 20$.
Cyanogas. (A) Dust. For outside use in killing all rats, moles, woodchucks, gophers, and ground squirrels. Also effective for destroying white grubs and crayfish in lawns. Lb. 75 cts.; 5 Ibs. \$3; 25 Ibs. \$10.

*Ever Green. Effective against cutworms, cucumber beetles, cabbage worms, rose slugs, aphis, thrip, etc. Will not injure tender plants or roses. It is safe to use because it is a non-poisonous material. Oz. 35 cts.; 6 ozs. $\$ 1 ; 16$ ozs. $\$ 2$; 32 ozs. $\$ 3.50$; gal. $\$ 13$.

*Fish-Oil Soap (Whale Oil Soap). An excellent summer spray for San Jose scale and all softshelled insects. Makes a good wash for trees where bark is affected by insects. Lb. 30 cts.; 5 Ibs. $\$ 1.25 ; 25$ Ibs. $\$ 5$.

Fungtrogen. An effective and scientific preventative and remedy for mildew, black-spot, and many fungous diseases of roses and other plants. Valuable for rust on carnations and snapdragons grown under glass. It is invisible on the foliage or blooms. $1 / 2 \mathrm{pt}$. 75 cts.; pt. $\$ 1.25$; qt. $\$ 2 ; 1 / 2$ gal. $\$ 3.50$; gal. \$6.

*Hellebore. In powder form. Effective against currant and cabbage worms, rose slugs, etc. $1 / 2$ Ib. 30 cts.; Ib. 55 cts.; 5 Ibs. $\$ 2.50$.

Insectrogen. A highly effective insecticide for leaf-eating insects, as caterpillars, slug worms, Japanese beetle, etc., and has definite fungicidal value for black-spot on roses. Destroys leaf-tier on chrysanthemums grown under glass. 4 ozs. 60 cts.; $1 / 2$ pt. $\$ 1$; pt. $\$ 1.75$; qt. $\$ 2.75$; 1/2gal. $\$ 4.50$; gal. $\$ 8$.

Lime-Sulfur, Dry. Less bulky, lighter, more convenient to handle, will not freeze and cheaper than Lime-Sulfur Solution. $10 \mathrm{Ibs}$. Dry is equivalent to $1 \mathrm{gaI}$. of Lime-Sulfur solution. For dormant spray use 10 to 14 Ibs. to 50 gals. of water; for summer spray 2 to 3 lbs. to 50 gals. of water. Lb. 35 cts.; 5 Ibs. $\$ 1.50 ; 10$ Ibs. $\$ 2.50 ; 25$ Ibs. $\$ 4.75$; 50 lbs. \$8; 100 Ibs. \$14.

Mag-o-Tite. To control root maggot, cornborers, cabbage worms, and slugs. 2 Ibs. for $300 \mathrm{ft}$. of row, $500 \mathrm{lbs}$. per acre. Lb. $50 \mathrm{cts}$.; 5 Ibs. $\$ 1.50 ; 25$ Ibs. \$5; 50 Ibs. \$9.

Nico-Fume Liquid. Use 1 part to 500 parts water; one tablespoonful to $11 / 2$ pints of water. $1 / 4 \mathrm{Ib}$. 75 cts.; Ib. $\$ 2.25 ; 4$ Ibs. $\$ 7.50$; 8 Ibs. $\$ 14$. (Weighs about 8 Ibs, to the gal.)

Nico-Fume Tobacco Powder. Destroys aphis in fumigating greenhouses. Lb. $\$ 1.25 ; 5$ Ibs. $\$ 4.50 ; 10$ Ibs. $\$ 8$.

*Nu-green. A grass disinfectant for brown patch prevention and control. 3 ozs. 50 cts.; Ib. $\$ 2 ; 5$ Ibs. \$9; 25 Ibs. \$37.50; 100 Ibs. \$145.

Paradichlorobenzene. Best for peach borer. Covered with soil surrounding the tree, it emits a heavy gas which descends throughout the root growth and destroys the pests. Lb. 75 cts.; 5 lbs. $\$ 2.75 ; 10$ Ibs. $\$ 5$.

Paris Green. Kills bugs, worms, and slugs. Used as powder; mix 1 part to 100 parts of flour; or in solution 1 pound to 200 to 300 gals. of water. $1 / 4 \mathrm{Ib}$. 15 cts.; Ib. 55 cts.; 5 Ibs. $\$ 2.50$. 


\section{Insecticides and Fungicides}

\section{Prices are subject to change without notice}

Pyrox. Mix 1 pound to 5 gallons of cold water. Safe all-round spray for killing leaf-eating insects; prevents blight and fungous troubles on potatoes, vegetables, rose bushes, fruit trees, etc. Lb. 50 cts.; 5 Ibs. \$1.75; 10 Ibs. $\$ 3.25 ; 25$ Ibs. $\$ 6.50 ; 50$ Ibs. $\$ 11.25 ; 100$ Ibs. $\$ 18 ; 300$ lbs. $\$ 50$

*Radioblight Soap. For delphiniums, carnations, roses, chrysanthemums, snapdragons, celeryrust, boxwood, rhododendrons, vines and hollyhocks. Controls blight, smut, red spider and fungoid diseases. Dissolve one pound in 5 gallons of water. Spray after sunset on cloudy days for smut and disease. Lb. \$1.25; 5 Ibs. $\$ 5.75 ; 10$ Ibs. $\$ 10$.

Scalecide. For San Jose scale. Non-poisonous preparation. Mix 1 gal. to 20 gals. of cold water. Use in late fall, winter or early spring, when foliage is off. Qt. 75 cts.; gal. \$1.75; 5 gals. $\$ 6.25 ; 10$ gals. $\$ 10.60 ; 50$ gals. $\$ 38$.

*Semesan. Successful for the malignant grass disease called "Brown Patch," on golfcourses, turf courts, and Iawns. 2 ozs. 50 cts.; Ib. \$2.75; 5 Ibs. \$13; 25 Ibs. \$62.50.

* Semesan Bel. Will prevent or control the common seed-borne potato diseases. $1 \mathrm{Ib}$. $\$ 1.75 ; 5$ lbs.. \$8; 25 Ibs. \$37.50.

*Semesan, Jr. Effective for the disinfection of corn seeds against the ear, root, and stalk rots. 4 ozs. 50 cts.; Ib. $\$ 1.75 ; 5$ Ibs, $\$ 8$; 25 Ibs. $\$ 37.50$.

*Slug-Shot. A non-poisonous powder, applied by dusting on the plants. Non-injurious to animals or fruit and vegetables treated. Effective remedy for potato bugs, beetles,

\section{Weed Killers}

There is nothing more annoying to the wellkept home grounds than weeds constantly coming up in the roadways, paths and gutters. These weed killers are harmless to stone, woodwork or shoes and are perfectly odorless.

Herbicide. Dilute with water, 1 gal. making 30 gals. of liquid, 1 gal. of which will cover about 25 sq. ft. of ground. For tennis courts, drives, etc. Kills all plant growth. Ot. 70 cts.; gal. $\$ 2$; 5 gals. $\$ 7.50 ; 10$ gals. $\$ 12.50 ; 30$-gaI. drum $\$ 30 ; 50$-gal. bb. $\$ 45$.

Non-Poisonous Weed Killer. Kills weeds safely and economically. Harmless to humans and animals. Qt. 70 cts.; gal. $\$ 2 ; 5$ gals. $\$ 7.50$; 10 gals. $\$ 12.50 ; 50$ gals. $\$ 45$. slugs, cabbage worms, etc. Lb. 25 cts. 5 lbs. 60 cts.; 10 Ibs. $\$ 1.20$; 25 Ibs. $\$ 2.75 ; 125$ Ibs. $\$ 12.50$; per bЫ. of 250 Ibs. $\$ 24$

*Snarol. Kills garden pests quickly. Stops damage by cutworms, snails, grasshoppers. Broadcast on ground, harmless to animals and fowls. Lb. 50 cts.; 3 Ibs. \$1; 15 Ibs. $\$ 3.75 ; 50$ Ibs. $\$ 11.50$.

*Terogen. A summer and autumn grounddressing and soil disinfectant. It destroys the spores of most fungous diseases and the larvæ of rose-pith borers, rose bugs, aphis, and beetles which have fallen to the ground. Helps to prevent chlorosis. In semi-powdered form. Lb. 75 cts.; 2 Ibs. $\$ 1.25 ; 5$ Ibs. $\$ 2.75$ 10 Ibs. $\$ 4.75 ; 25$ Ibs. $\$ 11 ; 100$ lbs. $\$ 40$.

*Tobacco Dust (Fine). For fumigating, dusting and a preventive against insects in ground around roots of trees. Lb. 10 cts.; $3 \mathrm{Ibs}$ 20 cts.; 5 Ibs. 30 cts.; 10 lbs. 50 cts.; 25 Ibs. $\$ 1.25 ; 50$ Ibs. $\$ 2.25 ; 100-$ Ib. bag $\$ 4$.

*Tree Tanglefoot. A sticky compound to protect trees from attacks of creeping insects. One application remains soft three months in all weathers; expands with trees. One Ib. makes 10 lineal ft. of band. Lb. 60 cts.; 5 lbs. $\$ 2.75 ; 10$ Ibs. \$5.25; 25 Ibs. \$11.

*Volck. A spray for scale insects, mealy bugs, white flies, red spiders, rust mites, etc. $1 / 2$ pt. 50 cts.; pt. 75 cts.; qt. \$1; gal. \$3; 5 gals. $\$ 12 ; 14$ gals. $\$ 24 ; 28$ gals. $\$ 38$.

Wilson's O. K. Plant Spray. An excellent general contact spray for garden or greenhouse. Dilute 1 qt. to 10 gals. water. 1/2pt. $40 \mathrm{cts}$; qt. $\$ 1 ;$ gal. $\$ 3 ; 5$ gals. $\$ 12 ; 25$ gals. $\$ 50$.

\section{Garden Tools and Accessories}

In our Plant Catalogue, which will be ready early in April, we offer a complete section of high-quality garden tools and accessories. In addition to the many essentials for garden and greenhouse culture, we offer a variety of things for garden decoration. These include bird-baths and houses, Dubois fencing, garden furniture, gazing-globes, sun-dials, and weather-vanes.

Our Plant Catalogue also includes a splendid choice of summer-flowering bulbs and roots, woodland plants, rock plants, ferns, perennial plants, roses, hedges, vines, flowering shrubs, evergreens, fruit trees, and aquatic plants. 


\section{Forbes Fertilizers and Soil-Builders}

The success of your garden depends upon the quality of the soil. AlI plants need ample plant-food. By ample is meant not only the quantity but also the availability. The soil must hold plant-food and moisture yet be in such condition that the plant roots can absorb what is needed. It should be sufficiently rich in humus or decayed vegetation to absorb excess moisture and hold it for later use. It should have enough clay to give it some body and enough sand to make it porous and friable. But even with a perfect soil, plant-food must be added each year to replace that which is consumed. The materials offered below are the best ones to help keep the soil in condition.

\section{Forbes Complete Garden Fertilizer}

This is the best for vegetables, flowers, and fruit, or for general garden use. It is a highgrade, well-balanced, complete fertilizer containing all the food elements needed for the quick growth, early maturity, and perfect development of vegetables and flowers. It is easily handled, being in dry, powdered form and is free from any objectionable odor.

Mix a little thoroughly through the soil in the bottom of the furrow before planting your seeds. Hoe it into the soil between the rows of plants, using about 5 pounds to 100 feet, and repeat this each month. Work a handful into the soil around the hills of beans, corn, cucumbers, melons, etc., and also when planting dahlias, peonies, peppers, tomatoes, etc. Scatter some around your shrubs and trees and rake it into the surface soil. After plowing or digging, and before harrowing or raking, apply 1,500 to 2,000 pounds to the acre, or about 25 pounds for every 500 square feet. Forbes Complete Garden Fertilizer is rich in potash and phosphoric acid and should be used even though manure, which is deficient in these but rich in nitrogen, has been applied. 5 Ibs. 50 cts.; 10 Ibs. 90 cts.; 25 Ibs. \$1.60; 50 Ibs. \$2.75; 100 Ibs. \$4.75; 500 Ibs. \$19; ton $\$ 65$.

\section{Bone-Meal}

This is excellent for top-dressing lawns. As the feeding rootlets of plants assimilate their food in liquid form, a fertilizer that disintegrates slowly before it becomes soluble will supply plant-food over a long period of time. Because of its slow disintegrating and long-lasting qualities, Bone-Meal is very desirable for fertilizing all hard-wooded plants, including roses, flowering shrubs, fruit bushes, and trees.

A Iiberal application of Bone-Meal mixed into the soil before planting bulbs of tulips, hyacinths, etc., will result in remarkable size and brilliancy of the flowers. For lawns it is a dependable fertilizer, as it contains the essential elements that grass requires. It may be broadcast as a top-dressing at any time either in early spring or during the growing season with beneficial results. For this use 1,000 Ibs. per acre or 25 lbs. for every $1,000 \mathrm{sq}$. ft. For trees and vines, use 2 to 4 Ibs. each. For roses and pot plants, use 1 part to about 50 parts of soil. For freld and garden crops or in making new Iawns, use 1,500 to 2,000 Ibs. per acre, or about $50 \mathrm{Ibs}$. for every 1,000 sq. ft. of lawn. 5 Ibs. 50 cts.; 10 lbs. 90 cts.; 25 lbs. $\$ 1.60 ; 50$ Ibs. $\$ 2.75 ; 100$ Ibs. $\$ 4.75$; 500 Ibs. \$19; ton \$65.

\section{Forbes Perfection Lawn Dressing}

To maintain a fine Iawn in the best of condition, it is necessary to add plant-food in the form of a well-balanced fertilizer. The removal of the grass clippings after each mowing robs the Iawn of one of its sources of plant-food. Top dress your lawn twice each year, once before the new spring growth commences and again in the fall before active growth stops. This practise will induce deep, thick, root-growth which will enable the lawn to better withstand the hot, dry summer months. You will also see a marked improvement in the color and fine texture of the Iawn grass. Top-dressing with commercial fertilizer will materially help to rid the Iawn of weeds. It will greatly increase the number of fine rootlets under the lawn, and these, forming a compact root-mat, will strangle and destroy all the coarse weed-growth. Forbes Perfection Lawn Dressing adds more plant-food than twice its value in stable manure, the use of which should be avoided as it brings weed seeds to your lawn. On a new lawn, broadcast 1,500 to 2,000 pounds per acre or 25 pounds for every 500 square feet. For top-dressing, apply evenly 1,000 pounds to the acre or 25 pounds for every 1,000 square feet. In hot weather, use half this quantity and water in thoroughly with a hose. 5 Ibs. 50 cts.; 10 Ibs. 90 cts.; 25 Ibs. \$1.60; 50 Ibs. $\$ 2.75 ; 100$ lbs. $\$ 4.75 ; 500$ Ibs. $\$ 19 ;$ ton $\$ 65$.

\section{Sheep Manure}

Among the organic fertilizers, Sheep Manure is the most valuable. It contains all the essential plant-food elements of stable manure without the bulk and waste matter. It is assimilated rapidly by plant-life and promotes a healthy and vigorous growth. Sheep Manure is dried, screened, sterilized, ground and pulverized. The Flower- and Vegetable-Garden is particularly benefrted by the use of Sheep Manure. Spread at the rate of $100 \mathrm{lbs}$. to $1,000 \mathrm{sq}$. ft., or 2,000 to 3,000 Ibs. to the acre, after plowing and before the final harrowing. Lawn Grass thrives Iuxuriantly when fed with Sheep Manure. Use 100 Ibs. per $1,000 \mathrm{sq}$. $\mathrm{ft}$. Scatter broadcast over the old lawn or rake thoroughly into the top soil a day or two before seeding a new one. In potting soil, for greenhouse plant-culture, one part Sheep Manure to six parts soil is the usual proportion. For liquid manure, use one pound of Sheep Manure to five gallons of water. In carnation, chrysanthemum or rose houses it is often used for a light top-dressing. 5 lbs. 50 cts.; 10 Ibs. 90 cts.; 25 Ibs. $\$ 1.60 ; 50$ Ibs. $\$ 2.75$; 100 Ibs. \$4.75; 500 Ibs. \$19; ton $\$ 65$.

We make prompt delivery of fertilizers, insecticides, lawn grass seed, and other materials offered, to all points within our suburban delivery area without additional charge 


\section{General List of Fertilizers and Soil-Builders}

Acid or Rock Phosphate. (16 per cent available Phosphoric Acid.) Adds phosphoric acid and a small quantity of lime. Apply from 750 to 1,500 Ibs. to an acre of plowed land or it may be used as a top-dressing for Iawns, golf fairways, etc. 100 Ibs. $\$ 2.50 ; 500$ Ibs. $\$ 11$; ton $\$ 38$.

Adco. For making artificial manure. This manure is made by stacking straw, leaves and other vegetable waste, Iayer by Iayer, mixing it with Adco, and keeping it wet until weIl rotted. Directions with each shipment. A 25-Ib. bag is enough for about twelve wheelbarrow loads of garden waste, making about $1 / 2$ ton of manure. 25-lb. bag $\$ 2.25 ; 100-\mathrm{Ib}$. bag $\$ 8.25 ; 150$-lb. bag $\$ 10.50$.

Ashes, Canada Hardwood. These ashes contain potash and lime, which are essential, not only as plant-food, but also as sweeteners of the soil and solvents of other plant-food ingredients. One of the best fertilizers for top-dressing lawns and grass-Iands, imparting a rich, dark shade of green, destroying many insects and weeds, particularly moss. Use $1,500 \mathrm{Ibs}$. to the acre or 100 Ibs. to 1,500 sq. ft. Also good for fruit, especially strawberries, peaches, and apples. 25 Ibs. $\$ 1.25 ; 50$ Ibs. $\$ 1.75 ; 100$-Ib. bag $\$ 3$; bbI. (about 200 Ibs.) $\$ 6$; ton $\$ 45$.

Clay's Fertilizer. Has a splendid reputation for flowers, vegetables, and fruit. Gardeners have used it successfully for exhibition growing. Rake into the soil around the plants at the rate of $1 / 2 \mathrm{Ib}$. to 20 sq. ft. 7 Ibs. $\$ 1.50 ; 14 \mathrm{lbs}$. $\$ 2.25 ; 28$ Ibs. $\$ 4 ; 56$ Ibs. $\$ 7 ; 112$ Ibs. $\$ 12$.

Compost or Spent Mushroom Soil. Stable manure and fine loam, which together have produced a crop of mushrooms and are partly rotted. Excellent for mulching or top-dressing roses, evergreens, and fruit trees. For lawns, use $400 \mathrm{lbs}$. per 1,000 sq. ft., broadcast evenly and rake well into the soil. If properly done the growth of the grass will be tremendously stimulated. When repotting plants this product is indispensable in the preparation of the soil. 100 Ibs. $\$ 2 ; 1,000$ Ibs. $\$ 13$; ton $\$ 25$. Special quotations in car-lots, 30 tons up.

Dahlia Food, Springfield. A chemically compounded fertilizer containing those elements necessary to produce exhibition Dahlias. 10 Ibs. $\$ 1.25 ; 25$ Ibs. $\$ 2.50 ; 100$-Ib. bag $\$ 7.50$.

Floranid (Urea). This most highly concentrated nitrogenous fertilizer contains 46 per cent of available nitrogen, and leaves no harmful residue in the soil. A quick-acting stimulant for lawns, vegetables, fruits, and flowers. Clean and odorless. Use $1 \mathrm{Ib}$. to $75 \mathrm{sq}$. $\mathrm{ft}$. in the garden, $1 \mathrm{Ib}$. to $300 \mathrm{sq}$. ft. of lawn; in the latter case it must be mixed with four times its bulk of soil. To use in liquid form, dissolve 1 teaspoonful to a gal. of water. Lb. 50 cts.; 5 Ibs. $\$ 1.50 ; 10$ Ibs. $\$ 2.50 ; 25$ Ibs. $\$ 5$.

Humus. Furnishes but little plant-food; highly valuable, however, as a soil ingredient, improving its texture and increasing its waterholding properties. Humus lightens clay soils and increases their drainage, conversely it binds together sandy soils and helps them retain moisture. Also largely used mixed with soil for potting soil and for seed-flats. May be used freely. 100 lbs. will cover 80 sq. ft. 1 in. deep. Apply, as a lawn top-dressing, 400 to $800 \mathrm{Ibs}$. to every 1,000 sq. $\mathrm{ft}$.; 8 to 15 tons per acre. 50 Ibs. $\$ 1.50 ; 100$ Ibs. $\$ 2.50$; 500 Ibs. $\$ 10$; ton $\$ 35$.
Lime, Hydrated Agricultural. Corrects acid conditions of the soil, and at the same time liberates other foods in the soil. Binds loose soils and opens heavy land. It is very quickacting but will not burn if scattered evenly when Iawn is dormant. As an early spring or late fall dressing for lawns, broadcast 1 ton to the acre or 50 Ibs. per 1,000 sq. ft. 5 Ibs. 30 cts.; 10 Ibs. 50 cts.; 25 Ibs. $\$ 1$; 50 Ibs. $\$ 1.50$; 100 Ibs. $\$ 2 ; 500$ Ibs. $\$ 8.75$; ton $\$ 30$.

Lōma. Beautifres lawns and gardens. To build up a lawn you can be proud of, use Löma, the scientific plant-food. Löma is rich in potash, phosphate, and nitrates-just the food-elements your lawn or garden needs. Lōma promotes deep root-growth--makes the grass so sturdy it won't burn out quickly in the summer sun, so thick that it actually crowds out the weeds. Lōma is odorless, clean-many times more powerful than barnyard manures. Just sow it over the lawn like grass seed. Then wet it down. 5 Ibs. fertilizes a $10 \times 10 \mathrm{ft}$. plot, or 50 Ibs. for 1,000 sq. ft. 5 Ibs. 60 cts.; 10 lbs. $\$ 1 ; 25$ Ibs. $\$ 2 ; 50$ Ibs. $\$ 3.50 ; 100$ Ibs. \$6.

Mapes Corn Manure. Analysis: Ammonia, 3 to $3.50 \%$; total Phosphoric Acid, 10 to $12 \%$; available Phosphoric Acid, 8 to $10 \%$; Soluble Potash, actual, 3 to $4 \%$. For sweet corn, fodder corn, Hungarian grass, millet, late turnips, Iate cabbage, and seeding to grass. On heavy or average good Iand, particularly when stable manure is broadcast, use 200 or 400 Ibs. per acre, scattering in hills and drills; on light lands, use broadcast 600 Ibs. per acre. 100-Ib. bag $\$ 3.75$; ton $\$ 60$.

Mapes General Crop Manure. Analysis: Ammonia $2 \%$; available Phosphoric Acid, $8 \%$. An excellent fertilizer for general use in the vegetable-garden. It will be found a good substitute for stable manure but is cleaner and easier to handle. On good soil, $100 \mathrm{Ibs}$. will fertilize $2,500 \mathrm{sq}$. ft. 100 -lb. bag $\$ 3$; ton $\$ 50$.

Mapes Potato Manure. Analysis: Ammonia, 4.50 to $5 \%$; total Phosphoric Acid, 8 to $10 \%$; available Phosphoric Acid, 7 to $9 \%$; Soluble Potash, actual, 5 to $6 \%$. For potatoes, sweet potatoes, asparagus, sweet corn, sugar beets, strawberries, and aII small fruits. Use in hills or rows, mixing with soil thoroughly, at the rate of 800 Ibs. per acre on ordinary Iand. 100 -Ib. bag $\$ 4.50$; ton $\$ 70$.

Muriate of Potash. (About $50 \% \mathrm{~K}_{2} \mathrm{O}$.) The essential element for the proper development of all root crops. Use 350 to 750 Ibs. per acre. A combination of one part muriate with four parts bone-meal makes a most satisfactory top-dressing for dahlias. Use a handful to the plant. Apply in Iate JuIy or early August working in thoroughly but avoiding contact with the plant. 5 Ibs. $\$ 1 ; 10$ Ibs. $\$ 1.75 ; 25$ Ibs. $\$ 2.50 ; 100$ Ibs. $\$ 7$.

Nitrate of Soda. A plant stimulant. Adds nitrogen in a form which is immediately available to the plants. Forces a heavy, succulent growth in Iettuce and similar leaf vegetables. Use it sparingly and with great care; not more than $1 \mathrm{lb}$. to $100 \mathrm{sq}$. ft., or $500 \mathrm{lbs}$. to the acre raked or harrowed in. For lawns, use 5 Ibs. per $1,000 \mathrm{sq}$. ft., but first mix with four times its bulk of fine soil or sand. As a liquid fertilizer $1 \mathrm{oz}$. may be dissolved in $1 \mathrm{gal}$. of water. 5 Ibs. 60 cts.; 10 Ibs. $\$ 1 ; 25$ Ibs. $\$ 2 ; 50$ Ibs. $\$ 3.50 ; 100$ Ibs. $\$ 6 ; 500$ Ibs. $\$ 25$; ton $\$ 80$. 


\section{General List of Fertilizers and Soil-Builders}

Nitrophoska. A very well-balanced, quick-acting food for every purpose in the garden, on lawns, flowers, shrubs, and vegetables. Contains: Nitrogen, $15 \%$; Phosphoric Acid, $30 \%$; Potash, $15 \%$. For the garden or flowers, use 5 to $10 \mathrm{Ibs}$. for each 1,000 sq. $\mathrm{ft}$. of soil, thoroughly raking into the soil after broadcasting over the surface. For lawns, apply 6 to $10 \mathrm{Ibs}$. per 1,000 sq. ft. in early spring and follow with subsequent applications every two months. Hose your lawn thoroughly after each application which will assure vigorous growth and a Iuxuriant Iawn. Lb. 35 cts.; 5 Ibs. $\$ 1.25 ; 10$ Ibs. $\$ 2 ; 25$ Ibs. $\$ 4$.

Peat Moss, Granulated. A vegetable product which remains in the soil for many years without decaying; in the meanwhile it absorbs moisture and holds it for the plants. Used extensively for mixing in soil for pot plants and is an excellent medium in which to grow bulbs. Mixed with soil it is ideal for making a Iawn, a flower- or vegetable-garden. It is also used for mulching perennial and rosebeds as weII as around evergreens. Many use Peat Moss for packing and storing bulbs, such as cannas, dahlias, etc. SmaII bale (about 12 Ibs.), enough to cover 16 sq. ft. 1 in. deep, $\$ 1.50$; Iarge bales (13 cu. ft.; about $190 \mathrm{Ibs}$.), enough to cover 240 sq. ft. 1 in. deep, \$5. In lots of 5 large bales, $\$ 4.50$ each. Special quotations on carload lots.

Potting Soil. A fine mixture of loam, leafmold, and sand. Suitable for house plants, ferns, etc.; excellent for growing bulbs. Qt. 10 cts.; pk. 65 cts.; bus. \$2.25.

Rose-Food, Springfield. An organic fertilizer, containing the vital elements of plant-life in scièntifically correct proportions to make it an ideal food for roses. Will keep your bushes in splendid condition and produce an abundant crop of perfect blooms. 10 Ibs. \$1.25; 25 Ibs. $\$ 2.50 ; 100$ Ibs. $\$ 7.50$.

SaIt, AgriculturaI. Occasionally used as a topdressing for asparagus. Also effective as a weed-killer on roadways, paths, etc. 50 Ibs. $\$ 1.50 ; 100$ Ibs. $\$ 2.25 ; 500$ Ibs. $\$ 10$; ton $\$ 35$.

Sulphate of Ammonia. A nitrogenous plantstimulant, very quick in action, tending to make soil acid. Increases leaf-growth. Much used on lawns as a stimulant and to discourage weed-growth. When top-dressing lawns apply $1 \mathrm{Ib}$. to every $150 \mathrm{sq}$. ft. or 300 Ibs. to the acre, but first mix with several times its bulk of soil or sand. Between rows of spinach, lettuce, cabbage, etc., scatter 3 Ibs. to 100 running feet and hoe it in. As a liquid stimulant dissolve $1 \mathrm{oz}$. in a gal. of water and apply to the roots avoiding contact with the plants. 5 Ibs. 85 cts.; 10 Ibs. $\$ 1.50 ; 25$ Ibs. $\$ 2.50 ; 50$ Ibs. \$4; 100 Ibs. \$7; 500 Ibs. \$30; ton $\$ 110$.

Vigoro. A superior combination of plant-foods that meets nature's most exacting requirements. When Vigoro is used, no supplementary substances are required. If applied to plants grown on benches or in pots, it should be worked into the soil and the plants then watered. For top-dressing the lawn in spring, use 40 Ibs. for every 1,000 sq. ft. 5 Ibs. 75 cts.; 25 Ibs. $\$ 2.25 ; 50$ Ibs. $\$ 3.50 ; 100$ Ibs. \$6.

\section{Seed Inoculator}

\section{Stimugerm}

\section{Nitrogen-Fixing Bacteria for all Leguminous Plants}

Small Garden Unit. A composite culture of the bacteria essential for the growth of Peas, Beans, and Sweet Peas. Unit 25 cts., postpaid 35 cts.

Clover Units. CuIture of bacteria necessary for the growth of Alfalfa and all Clovers. Sufficient to treat $1 / 4$ bus. of seed 35 cts.; $1 / 2$-bus. size 60 cts.; bus. size $\$ 1 ; 21 / 2$-bus. size $\$ 2.25$. Full directions for developing the bacteria and applying them to the seeds will be found on the package. When ordering state the clover for which Stimugerm is required.

Large Seed Units. Culture of bacteria for Garden Peas, Beans, Sweet Peas, Peanuts, Vetches, and Field Peas. 1/2-bus. size $35 \mathrm{cts.;}$ bus. size 60 cts.; 5-bus. size $\$ 2.25$. When ordering, state the crop for which Stimugerm is required.

\section{House Plant-Foods}

Fertilis Tablets. A clean, odorless plant-food in tablet form; contains highly concentrated, immediately available forms of plant-food for use in stimulating all fruit, flower, vegetable, and ornamental plants May be used in tablet or liquid form. Pkg. (100 tablets) 25 cts.

Plantabbs. Odorless plant-food tablets made especially to keep your ferns, geraniums, cyclamen, begonias, rubber plants, and other potted plants healthy and growing while inside during the winter. While particularly adapted to feeding indoor plants, being without odor, they will benefit outdoor garden flowers, bulbs, vines, and garden vegetables. They are perfectly safe to use. Box of 30 tablets 25 cts.; 75 tablets 50 cts.; 200 tablets $\$ 1 ; 1,000$ tablets $\$ 3.50$.

Superior Plant-Food. Feed your plants new life and beauty with Superior Plant-Food, universal in its year-round use. Use it on potted ferns or plants, roses, hardy shrubs, trees and lawn. Just dissolve a teaspoonful in the watering-pot every time you sprinkle. Clean and odorless. 3-oz. can 25 cts.; 7-oz. can 50 cts.; 16-oz. can $\$ 1$.

Watch-em-Grow. A highly concentrated, odorless fertilizer for house plants. May be used in the natural powdered form or can be dissolved in water at the rate of one teaspoonful to each gallon of water. Apply once or twice a week until vigorous growth is promoted and throughout the blooming period. Guaranteed Analysis: Ammonia, soluble in water, 19\%; available Phosphoric Acid, 10\%; Petash, soluble in water, $14 \%$. This is an ideal balance for quick plant-food. A trial will soon show amazing improvement in your house ferns and other pot plants. Large 8-oz. can, 50 cts.

We make prompt delivery of fertilizers, insecticides, lawn grass seed, and other materials offered, to all points within our suburban delivery area without additional charge 


\section{Alphabetical Index}

FLOWER SEEDS

Abronia . . . . . . . . . . . . . 21

Aconitum................65

Acroclinium .............. 21, 36

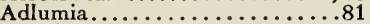

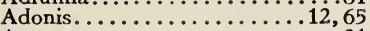

Ageratum . . . . . . . . . . . . 21

Agrostemma..............65

Alkanet................67

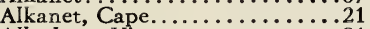

Allegheny Vine..............81

Aloysia.................61

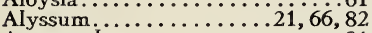

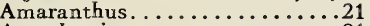

Ampelopsis . . . . . . . . . . . ${ }^{2}{ }^{8}{ }^{81}$

Anchusa................ $12,21,67$

Anemone........... 57, 67, 82

Antirrhinum. .........22, 23, 64

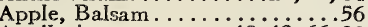

Aquilegia ..........12, 13, 66, 82

Arabis...............67,82

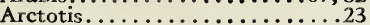

Arenaria ............... 67,82

Aristolochia.............. . 81

Armeria.............67,82

Asparagus, Ornamental........57

Aster, Cornflower..............79

Aster, Lilac Alpine... . . . . . . . . . . .

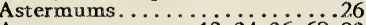

Asters. .........12, 24-26, 68, 82

Aubrietia............. 67, 82

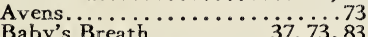

Bachelor's Button......................

Balloon Flower, Dwarf .........

Balloon Viue.............. . 55

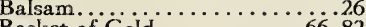

Basket of Gold . . . . . . . . . . . . . . . 66 . 86

Bean, Hyacinth . . . . . . . . 56

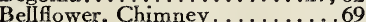

Bellflower, Chinese. . . . . . . . .77

Bellis.................68

Bittersweet.............. . . 81

Blanket Flower.............. . . . . . . . . .

Blue I.ace Flower. . . . . . . . . . 35

Boltonia.................68

Brachycome.............. . . . . . . . . .

Butterfly Flower. . . . . . . . .49, 60

Calceolaria. . . . . . . . . . . . 57

Calendula . . . . . . . . . 13, 28, 62

Calliopsis............... 28

Campanula . . . . . . . . . . . . 69, 82

Campion, Rose ............... . 65

Campion, Rose .............. . . . 65

Candytuft.......... $28,6 \dot{2}, 6 \dot{8}, 83$

Canterbury Bells...........69 69

Cardinal Climber............55

C.ardinal Flower............. $\ldots \ldots$

Carnation ..........13, 29, 62,69

Castor oil Bean .............48

Catchfly $\ldots \ldots \ldots \ldots \ldots \ldots \ldots \ldots .75,83$

Catchfly, German.......... . 75, 83

Catmint, Caucasian.......... 83

Celastrus...............81

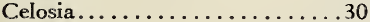

Centaurea . . . . . . . . . . 31,62

Cerastium . . . . . . . . . . . 70,82

Chamomile, False..........68

Chelone................ 70,82

Cherry, Cleveland............61

Cherry, Jerusalem . . . . . . . . . . . 61

Chrysanthemum......... 32, 70

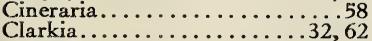

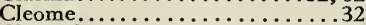

Clematis................ . . 81

Cobæa....................55

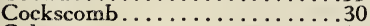

Coleus . . . . . . . . . . . . . . 34

Columbine............ $12, \dot{6} 6,82$

Convolvulus. . . . . . . . . . . 56
Page
74,83

Coral Bells. . . . . . . . . 74, 83

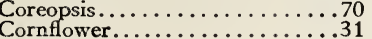

Cosmos.....................

Cowslip..................77, 83

Cress, False Wall .........67, 82

Cress, Rock $\ldots \ldots \ldots \ldots \ldots 67,82$

$\ldots . .82$

Cut-and-Come-Again . . . . .

Cyclamen..................58

Cynoglossum.............34, 62

Cypress, Summer............39

Cypress Vine .............. 55

Dahlia................

Daisy, African .......... 23, 35

Daisy, Blue Mountain . . . . 68, 82 .

Daisy, English .............6. 68

Daisy, Painted.............

Daisy, Shasta. ...........14, 70

Daisy, Swan River.

Daisy, Transvaal.......... $40,71,89$

Dianthus......14, 35, 51, 72, 80, 82

Didiscus.................. 63

Digitalis................72

Dimorphotheca............

Dolichos.................. 56

Dracæna.................59

Dragon Plant .........

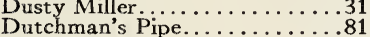

Edelweiss................ 72,83

Emerald Feather. . . . . . . . 57

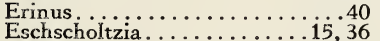

Euphorbia...

Everlasting Flowers..........36, 38

Everlasting Pea . . . . . . . . 81

Fern, Asparagus.............

Feverfew...............41

Fire-Plant, Mexican......... 36

Floss, Syrian. . . . . . . . .

Floss Flower ............21

Flowers for Different Situations

Forget-me-not . . . . . . 10.42, 76, 83

Forget-me-not, Chinese.......34, 62

Forget-me-not, Summer. . . . . . 21

Fountain Plant $\ldots \ldots \ldots \ldots \ldots \ldots 21$

Four-o'Clock........................

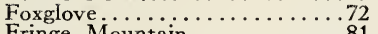

Fringe, Mountain ........... 81

Gaillardia $\ldots \ldots \ldots \ldots . .37,73$

Gentian, Blue.................73

Gentiana................ 73

Geranium............. 59

Geum............... 15, 73, 83

Geum ........................

Globe Amaranth .............36, 37

Globe of Fire . . . . . . .

Gloxinia ..................

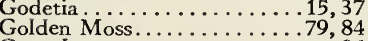

Gomphrena....................

Gourds, Ornamental. . . . . . . .56

Grasses, Ornamental. . . . . . . . .

Gypsophila .........

Harebell, Carpathian.......69, 82

Helianthemum..........74, 83

Helianthus ..................... 38

Helichrysum............

Heliotrope $\ldots \ldots \ldots \ldots \ldots \ldots . \ldots \ldots, 63$

Heliotrope, Garden . . . . . . . . .80

Hercules' Club. .............. 56

Hesperis.......................

Heuchera.............

Hibiscus................74

Hollyhock............ 39, 74

Honesty......................

Hop, Japanese................

Houseleek .............. 79,84

Humulus. ................... 56
Page

Iberis . .............. $28,68,8$

Ice Plant............... 42

Impatiens . . . . . . . . . 39,63

Incarvillea............ 74, 83

I pomœa.....................

Iris...................... 74

Ivy, KeniIworth .............

Jasmine, Cape............... 118

Johnny-Jump-up ............ 84

Joseph's Coat..............21

Kochia ................

Lace Flower, Blue..........

Lady's Slipper..............26

Lantana...............39,63

Lantern Plant, Chinese........29

Larkspur. $. \ldots \ldots \ldots . \ldots 16,40,63,71$

Lathyrus.................... 81

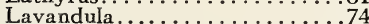

Lavatera......................

Lavender...............74

Lavender, Cotton.........78,84

Leontopodium .............. 72,85

Linaria................. 73

Linum ............75, 83

Love-in-a-Mist................ 40,44

Love-lies-bleeding................ 21

L.upine............. 41,75

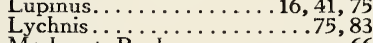

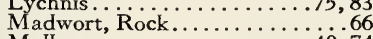

Mallow............. 40,74

Marigold. ...............16, 41

Marigold, Pot................. 28

Marvel of Peru....................

Matricaria...................

Matthiola . . . . . . . . .

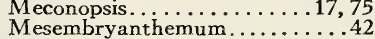

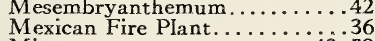

Mignonette.............42, 59

Mimosa .............. 42,59

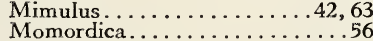

Monkey Flower.......... 42,63

Monkshood..............65

Moonflower..................56

Moonwort $\ldots \ldots \ldots \ldots \ldots \ldots \ldots \ldots \ldots \ldots \ldots, 63$

Musk Plant.............. 42,63

Myosotis...........42, 63, 76, 83

Nasturtium : ..............43

Nemantirrhinum..........

Nemesia..............443,63

Nepeta ...............76, 83

Nettle, Flame...............

Nicotiana..................43

Nigella................ 44

Enothera . . ............76, 83

Ornamental Gourds..........

Ornamental Grasses............

Pansy................. 19, 44, 63

Papaver............... 47, 83

Pasque Flower...........6. 67,82

Pear, Balsam

Pentstemon ....................

Periwinkle, Madagascar........... 52

Petunia ..........17, 45, 46, 64

Phlox...............46,76

Physalis................29

Pin-cushion Flower......... 49, 78

Pink....................

Pink, China................

Pink, Chinese...........

Pink, Maiden .................. 72,82

Pink, Pheasant's-Eye . . . . . . .

Platycodon .............77, 83 


\section{Alphabetical Index}

Poinsettia, Annual.... $\ddot{1} \ddot{4} \ddot{7} \dot{7} \mathbf{3}$

Poppy, California . . . . . . . . . . . 36

Poppy, Oriental . . . . . . . . . . . . .777

Poppy, Thibetan............. . . 75

Poppy, Satin............ . 75

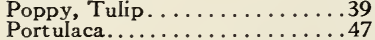

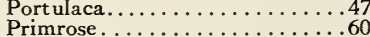

Primrose, Cashmerian. . . . . . . . 83

Primrose, English . . . . . . . 77, 84

Primrose, Evening. . . . . . . . . 76, 83

Primrose, Laced....... . . . .

Primula ......... 60, 77, 83, 84

Pyeraria .............. . .

Red-hot Poker Plant..........80

Reseda................ 42

Rhodanthe . . . . . . . . . 36, 48

Rockfoil . . . . . . . . . . . . . . 78,84

Rose, Rock. . . . . . . . . . . . . 74, 83

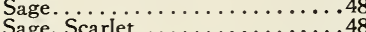

Sage, Scarlet... . . . . . . . 48.48

Salvia....

Sandwort

Santolina.

Sanvitalia.

Saponaria

Satin Flower

Saxifraga.

Scabiosa.

Schizanthus.

Sedum

Sempervivum

Sensitive Plant

Shasta Daisy.

Sidalcea.

Silene.

Smilax....

$19,48,78$

4,78
78,84

Yarrow.

Page

Zinnia . . . . . .........

\section{VEGETABLE SEEDS}

Anise..................95

Artichoke................ . . 85

Asparagus. . . . . . . . . . . . 85

Basil, Sweet.............. 95

Beans............... . 85-87

Beets... . . . . . . . . . . . . . 87

Borage............... . . . 95

Broccoli. . . . . . . . . . . . . 88

Brussels Sprouts..... . . . . . . 88

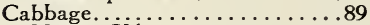

Cabbage, Chinese............ . . 88

Cantaloupe................98

Cardoon................... 88

Carrots..................990

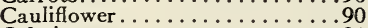

Celeriac. . . . . . . . . . . . . .91

Celery . . . . . . . . . . . . . . .991

Chicory . . . . . . . . . . . . 92

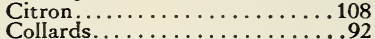

Corn Salad . . . . . . . . . . . . . 93

Corn, Sugar or Sweet . . . . . . 92,93

Cress . . . . . . . . . . . . . . 93 93

Cucumbers. . . . . . . . . . . .94

Dandelion............. . 94

Eggplant. . . . . . . . . . . . . . 94

Endive. . . . . . . . . . . . . 95

Fennel.................95

French Endive. . . . . . ...... 108

Gumbo.......... . Mèdicinal. . 100

Horse-radish . . . . . . . . . .995

Kale. ...............96

KohIrabi . . . . . . . . . . .96

Lavender. . . . . . . . . . . . .95

Leeks. . . . . . . . . . . . . . . . 9796

Marjoram, Sweet . . . . . . . . . . . . 95

Marrow, Vegetable. . . . . . . . . 105

Melons, English Forcing . . . . . . .98

Mushroom Spawn. . . . . . . . . .999

Muskmelons................ 98

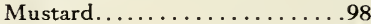

Okra................... 100

Oyster Piant..........................

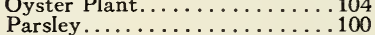

Parsnips....................

Peas................... 101

Peppers.................... 102

Pumpkins . . . . . . . . . . . 102

Radishes.................... 103

Rhubarb................ 104

Rosemary ............... . . 95

Rutabagas......... . . . . . . 108

Sage. . . . . . . . . . . . . . . 95

Savory, Summer............. . . . . . . . . . . . 104

Spinach . . . . . . . . . . . . . . 104

Squashes.................. . 105

Swiss Chard. .............887

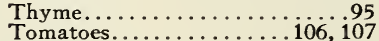

Tomatoes............. 106, 107
Turnips 107

Vegetable Plants............ 108

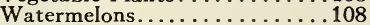

Witloof.................. 108

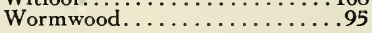

\section{FARM SEEDS}

Barley ..... . . . . . . . . . . 109

Beet, Sugar................. 114

Bermuda Grass.............. . 112

Bird Seed... . . . . . . . . . . . 109

Buckwheat . . . . . . . . . . . . . 109

Canada Blue Grass........... 112

Clover ................ 6,111

Corn, Ensilage............. 114
Corn, Field. ............114

Corn, Fodder. . . . . . . . . . . . . 114

Cowpeas . . . . . . . . . . . 110

Creeping Bent . . . . . . . . . 112

English Ryegrass.

Fescue, Fine-leavcd Sheep's. ....112

Fescue, Hard. . . . . . . . . . 112

Fescue, Meadow. . . . . . . . . . 112

Fescue, Red................113

Fescue, Sheep's. . . . . . . . . . . 113

Fescue, Tall ................... 113

Grass Seed . . . . . . . . 5-9, 112, 113

Italian Ryegrass............112

Kentucky Blue Grass. . . . . . . . . 112

Mangel-Wurzel.............. 114

Mcadow Foxtail............. 112

Millet................... 109

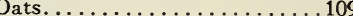

Orchard Grass............. 113

Peas, Field.............. 110

Permanent Pasture Grass........113

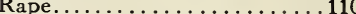

Redtop................. 113

Rough-stalked Meadow Grass. . 113

Rye..................110

Soy Beans................ 110

Sudan Grass. . . . . . . . . . . 113

Tall Meadow Oat Grass........ 113

Timothy.............. 113

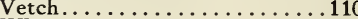

Wheat................ 110

Wood Meadow Grass. . . . . . . 113

\section{GREENHOUSE PLANTS}

Ageratum . . . . . . . . . . 119

Alyssum ...................... 119

Antirrhinum............118

Asparagus. ............... 118

Aster . . . . . . . . . . . . . 119

Beebalm, Blue.............. 118

Begonia................ 118

Bouvardia ............... 118

Buddleia.................... 118

Calceolaria . . . . . . . . . . . 118

Calendula . . . . . . . . . 118, 119

Carnations ............... 119

Chrysanthemums........... 118

Cineraria................. 118

Cosmos. . . . . . . . . . . 119

Cyclamen ................ 118

Euphorbia.................118

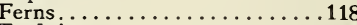

Fuchsia. . . . . . . . . . . 118

Gardenia ..................118

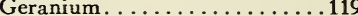

Gerbera................ 119

Heliotrope... . . . . . . . . . 119

Hydrangeas . . . . . . . . . . . 119

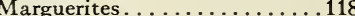

Marigold................. 119

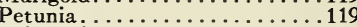

Poinsettias ............... 118

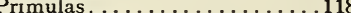

Pycnostachys . . . . . . . . . 118

Roses................... . 119

Salvia.................. 119

Smilax................... 118

Snapdragon............. 118, 119

Solanum . . . . . . . . . . . . . 118

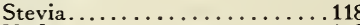

Verbena................ 119

Zinnia.................119

Books........84, 117, 120, 121

Cut-flowers............. 4

Fertilizers and Soil-Builders

$124,125,126$

Flower Plants.............119

Gladiolus............115-117

Insecticides, Fungicides.122, 123

Lawn Grass Seed.......... 5-9

Vegetable Plants........... 108 


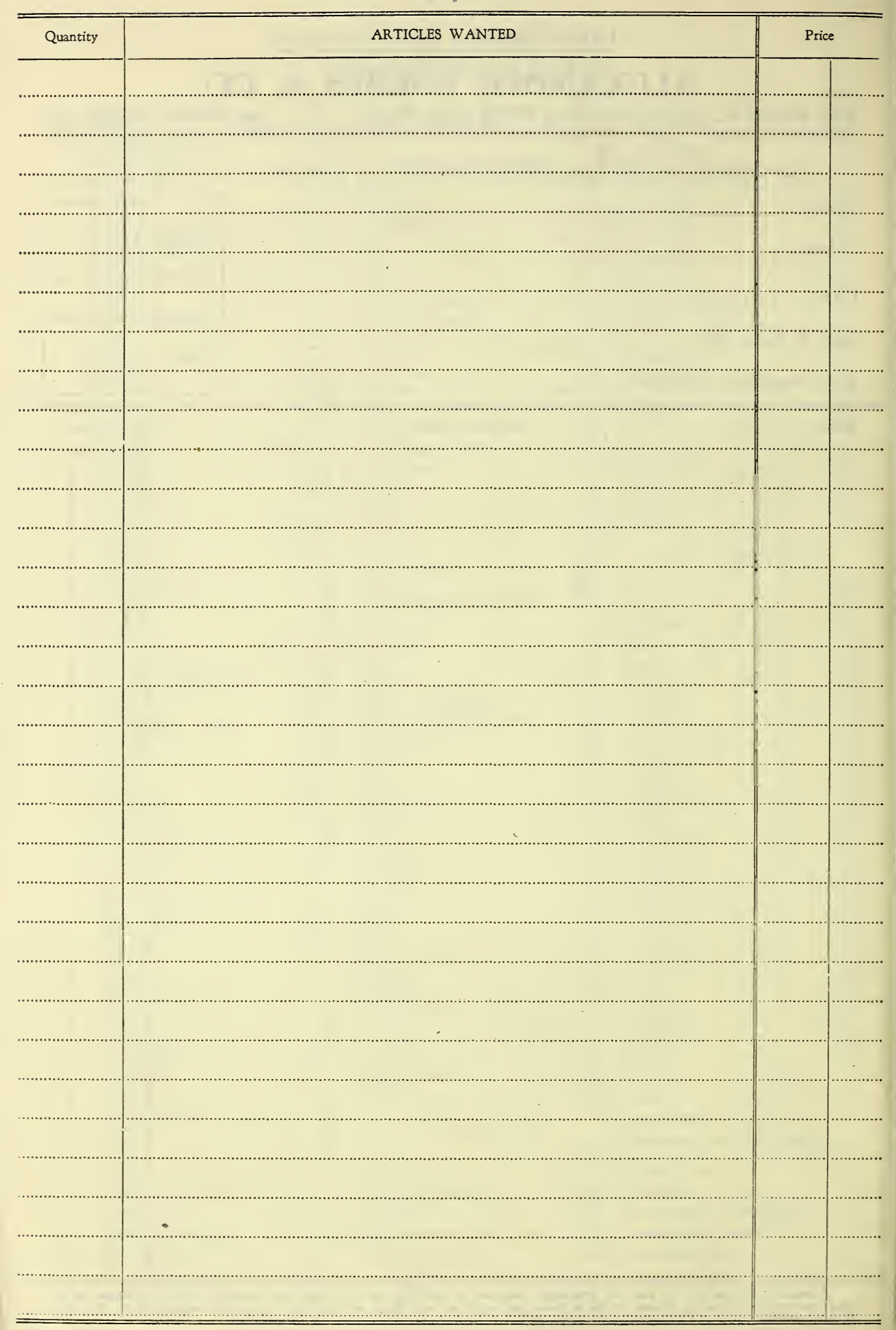


